UNIVERSIDADE DE BRASÍLIA

FACULDADE UnB DE PLANALTINA (FUP)

PROGRAMA DE PÓS-GRADUAÇÃO EM GESTÃO

PÚBLICA

RICARDO BORGES OLIVEIRA

COMUNICAÇÃO ORGANIZACIONAL INTEGRADA NA UNIVERSIDADE DE BRASÍLIA:

UM ESTUDO DE CASO

BRASÍLIA

DEZEMBRO/2015 
RICARDO BORGES OLIVEIRA

\section{COMUNICAÇÃO ORGANIZACIONAL \\ INTEGRADA NA UNIVERSIDADE DE BRASÍLIA: \\ UM ESTUDO DE CASO}

Dissertação apresentada ao Programa de Pós-

Graduação Stricto Sensu em Gestão Pública, da

Universidade de Brasília, como requisito parcial para a obtenção do título de Mestre em Gestão Pública.

Orientador: Professor Doutor Mário Ávila

BRASÍLIA

DEZEMBRO/2015 
Dissertação de autoria de RICARDO BORGES OLIVEIRA, intitulada "COMUNICAÇÃO ORGANIZACIONAL INTEGRADANA UNIVERSIDADE DE BRASÍLIA: UM ESTUDO DE CASO”, apresentada como requisito parcial para obtenção do grau de Mestre em Gestão Pública da Universidade de Brasília, em 07 de dezembro de 2015, defendida e aprovada pela banca examinadora abaixo assinada:

Prof. Dr. Mário Ávila

Orientador - Universidade de Brasília (UnB)

Prof. Dr. André Nunes

Examinador - Universidade de Brasília (UnB)

Prof. Dr. Marcelo Ximenes Aguiar Bizerril

Examinador externo - Universidade de Brasília (UnB)

Brasília 
À amada inspiradora Irlanda Aglae, companheira de vida; aos meus queridos filhos Tarsila e Vicente Luís; aos meus pais Raimundo e Neusa; aos meus irmãos Ana Jacira, Marisa, Eduardo e Isabel; aos meus sogros Mário Ernesto (em memória) e Maria Vesper. 


\section{AGRADECIMENTO}

Agradeço a minha família pelo apoio fundamental: minha amada Irlanda Aglae; meus filhos Tarsila e Vicente Luís; meus pais Raimundo e Neusa; meus irmãos Ana, Marisa, Eduardo e Isabel; meus sogros Mário Ernesto (em memória) e Maria Vesper; meu cunhado Ernesto e sua esposa Fernanda; meus sobrinhos Luísa, Vinícius, Catarina, Arthur, Beatriz, Paulo, João, Sophia e Marina.

Ao meu orientador, prof. Dr. Mário Ávila, por todo apoio ao longo desta jornada.

À amiga doutoranda Denise Lima, pela ajuda inestimável.

A Júlia Franco, pelo eficiente trabalho na transcrição das entrevistas.

À amiga Lia Nani e ao jornalista Flávio Castro, pela ajuda na revisão.

Ao primo José Mário, pela exímia tradução.

À jornalista da Secom Erika Suzuki, pela preciosa ajuda.

À chefe Neuza Meller, pela compreensão e pelo incentivo.

Aos colegas da UnBTV, pela força diária.

Aos colegas da primeira turma do PPGP/FUP/UnB: Aristides, Ivonaldo, Kelli, Laura, Lussara, Pedro, Priscilla, Rogério e Rivany, pelo companheirismo. Sem eles, tudo teria sido mais difícil.

Aos colegas da segunda turma do PPGP/FUP/UnB.

Ao Programa de Pós-Graduação (PPGP/FUP/UnB), que, em convênio com o Instituto Superior de Ciências Sociais e Políticas da Universidade de Lisboa (ISCSP), possibilitou conhecer modelos de gestão pública daquele país e participar de aulas nesse conceituado instituto.

Ao querido professor Elioenai (em memória), pelos ensinamentos.

Aos professores doutores André Nunes e Marcelo Bizerril, por aceitarem fazer parte da banca e pelas críticas e observações acerca deste trabalho.

Aos amigos Moacir, Thadeu, Marcelo Magalhães e Flávia. 
Em primeiro lugar, temos uma propriedade do comportamento que dificilmente poderia ser mais básica e que, no entanto, é frequentemente menosprezada: o comportamento não tem oposto. Por outras palavras, não existe um não-comportamento ou, ainda em termos mais simples, um indivíduo não pode não se comportar. Ora, se está aceito que todo o comportamento, numa situação interacional, tem valor de mensagem, isto é, é comunicação, segue-se que, por muito que o indivíduo se esforce, é-lhe impossível não comunicar (WATZLAWICK; BEAVIN; JACKSON, 1967, p. 44-45).

Não há, realmente, pensamento isolado, na medida em que não há homem isolado. Todo ato de pensar exige um sujeito que pensa, um objeto pensado, que mediatiza o primeiro sujeito do segundo, e a comunicação entre ambos, que se dá através de signos linguísticos. O mundo humano é, desta forma, um mundo de comunicação (FREIRE, 1977, p. 66).

A universidade de que precisamos, antes de existir como um fato no mundo das coisas, deve existir como um projeto, uma utopia, no mundo das ideias (RIBEIRO, 1982, p. 172) 


\title{
COMUNICAÇÃO ORGANIZACIONAL INTEGRADA NA UNIVERSIDADE DE BRASÍLIA: UM ESTUDO DE CASO
}

\begin{abstract}
RESUMO
No cenário atual de grandes mudanças, cada vez mais as organizações têm percebido a importância da comunicação para alcançar a sua missão e os seus objetivos. No âmbito das Instituições de Ensino Superior (IES) públicas, a comunicação exerce papel fundamental para a divulgação de sua finalidade, no que concerne ao ensino, à pesquisa e à extensão, e para a abertura de novos canais de diálogo e democracia. Nascida sob a perspectiva da inovação e autonomia, a Universidade de Brasília (UnB) tem buscado se inserir e influenciar na realidade que a cerca, em consonância com o seu estatuto de criação. Entretanto, enfrenta dificuldade em manter uma maior interlocução com a sociedade e com o seu público interno. Em grande medida, isso se deve à ausência de uma política de comunicação estratégica, que possibilite a integração dos setores de comunicação: Secretaria de Comunicação Social, Rádio UnB e UnBTV. Atualmente, esses setores atuam de forma isolada, sem coordenação de esforços e com grandes dificuldades estruturais. As fragilidades na comunicação interna e externa e a necessidade de integração da área foram apontadas no Plano de Desenvolvimento Institucional (PDI/UnB) 2014-2017. Nesse sentido, a Vice-Reitoria instituiu comissão para elaborar uma política de comunicação para a UnB. O principal marco teórico é o modelo de comunicação organizacional integrada, proposto por Margarida Kunsch. O estudo de caso buscou analisar as possibilidades de integração dos setores de comunicação da UnB, no contexto da Resolução n. ${ }^{\circ}$ 04/2013 da VRT. Para tanto, foram aplicadas entrevistas semiestruturadas, individualmente, a gestores, servidores e estagiários que atuam na comunicação da UnB, entre os meses de maio a agosto de 2015. As técnicas foram embasadas na abordagem da análise de conteúdo, observação participante e análise documental. Analisaram-se cinco categorias, emergidas dos objetivos da pesquisa: Setores de Comunicação da UnB, Planejamento da Comunicação da UnB, Comunicação organizacional Integrada, Comunicação Integrada em outras IES e Superintendência de Comunicação da UnB. Os dados coletados permitiram constatar que a criação de um órgão como uma superintendência de comunicação, modelo adotado em outras IES públicas brasileiras, poderia levar ao aperfeiçoamento da gestão da comunicação da UnB. Entretanto, a decisão depende de vontade política da cúpula da universidade e de maior debate no âmbito da própria área de comunicação.
\end{abstract}

Palavras-chave: comunicação, gestão, planejamento, universidade, UnB. 


\title{
INTEGRATED ORGANIZATIONAL COMMUNICATION AT THE UNIVERSITY OF BRASILIA: A CASE STUDY
}

\begin{abstract}
In the ever-changing current environment the organizations have realized the importance of the communication process in reaching their mission and goals. Within the scope of the public Higher Education Institutions (IES) communication plays a major role in divulging their purpose in regards to education, research and extension, as well as in the opening of new channels of dialogue and democracy. Born under the banner of innovation and autonomy the University of Brasilia (UnB) has always aimed at influencing and improving its surrounding reality, in accordance with the terms of its creation. However, it faces challenges in keeping a better dialogue with its internal public as well as with society at large. To a great extent that is due to the lack of a policy of strategic communication, which would enable the integration of its channels of communication: the Social Communication Secretariat, the University Radio (Rádio UnB) and the UnBTV. Currently these sectors work in an isolated form, without coordination and with great structural problems. Both the weaknesses in the internal and external communication and the need for integration have been diagnosed in the 20142017 Institutional Development Plan (PDI/UnB). For that reason the Vice-Rectory established a commission to elaborate a communication policy for the University. The main theoretical framework is the model of integrated organizational communication proposed by Margarida Kunsch. The case study sought to analyze the possibilities for integrating the communication sectors at $\mathrm{UnB}$, in the context of the VRT Resolution 04/2013. In order to accomplish that goal individual semi-structured interviews were conducted with managers, employees and trainees, between May and August 2015. The techniques were based on the approach of content analysis, participant observation and documentary analysis. Five categories were analyzed, emerged from the research objectives: Sectors of Communication at UnB, Communication Planning at UnB, Integrated Organizational Communication, Integrated Communication in others IES and Superintendence of Communication at UnB. The collected data led to the conclusion that the creation of an organism such as a Superintendence of Communication, modeled after the one adopted by others Brazilian public Higher Education Institutions could optimize the management of communication at UnB. Meanwhile, success essentially depends on the political will of the University summit level as well as on a greater debate within the scope of the communications area itself.
\end{abstract}

Keywords: communication, management, planning, university, UnB. 


\section{LISTA DE QUADROS}

Quadro 1 - Diferenças entre os níveis de planejamento ............................................48

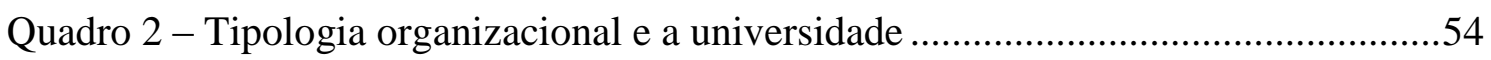

Quadro 3 - Universidade x empresa - características organizacionais ...........................57

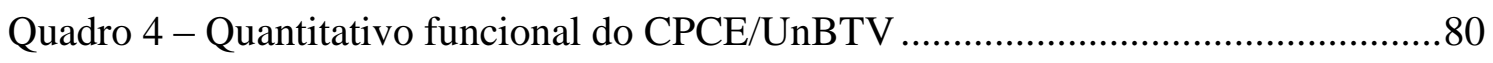

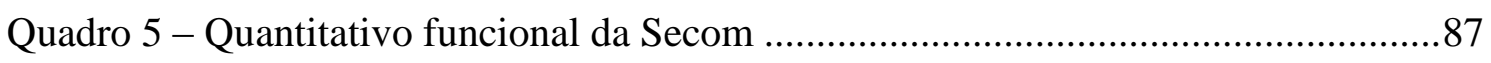

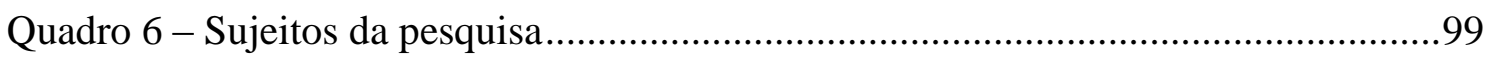

Quadro 7 - Instrumentos de comunicação da UnB ...................................................106

Quadro 8 - Avaliação da comunicação da UnB .........................................................107

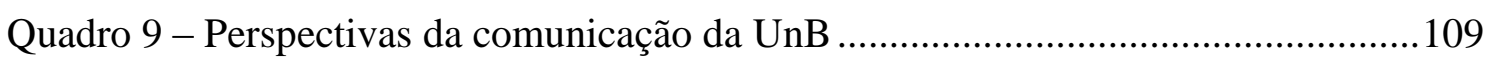

Quadro 10 - Quantitativo de profissionais e estagiários que atuam

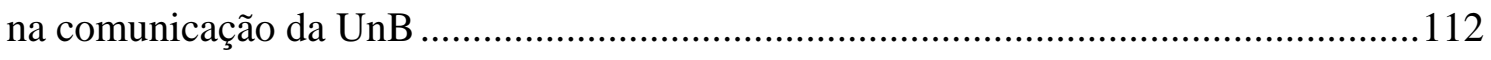

Quadro 11 - Avaliação do planejamento da comunicação da UnB .............................114

Quadro 12 - Perspectivas do planejamento da comunicação da UnB .........................116

Quadro 13 - Importância da comunicação integrada na UnB .....................................123

Quadro 14 - Perspectivas da comunicação integrada na UnB ...................................128

Quadro 15 - Experiências de comunicação integrada em outras IES

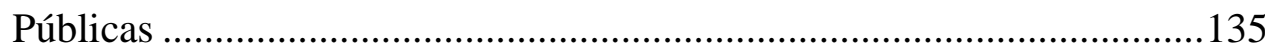

Quadro 16 - Avaliação do modelo de Superintendência de

Comunicação da UnB

Quadro 17 - Perspectivas da criação da Superintendência de

Comunicação da UnB 


\section{LISTA DE FIGURAS}

Figura 1 - Comunicação Organizacional Integrada .......................................................... 40

Figura 2 - Matriz SWOT UnB 2014 - Análise preliminar de objetivos e estratégias ..........64

Figura 3 - Organograma da Superintendência de Comunicação Social da USP ...................68

Figura 4 - Organograma da Superintendência de Comunicação Social da UFF ..................69

Figura 5 - Organograma da Superintendência de Comunicação da UFES ............................73

Figura 6 - Organograma da Superintendência de Comunicação da UFPI.............................. 74

Figura 7 - Organograma da Superintendência de Comunicação da UFRN ...........................76

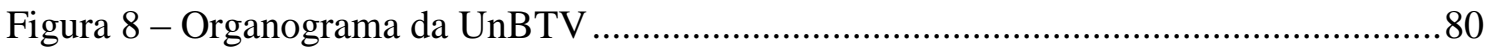

Figura 9 - Organograma da Secretaria de Comunicação da UnB ........................................8

Figura 10 - Organograma da Superintendência de Comunicação da UnB ............................90

Figura 11 - Secretaria de Comunicação (Secom) ...............................................................103

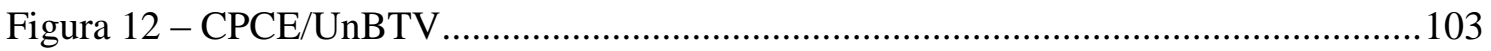

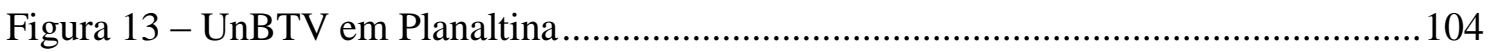

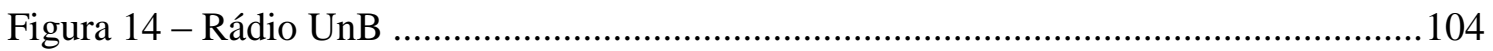

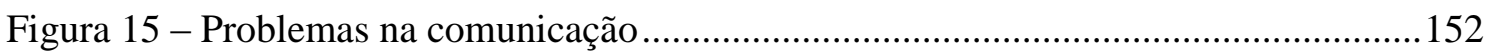

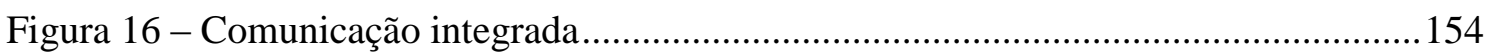




\section{SIGLAS UTILIZADAS}

AE

AGECOM/UFRN

CECOM

CEP

Ceftru

CIC

CONSUN/UFPI

Consuni

COORDCOM

CPCE

DAF

DPO

DF

EaD

EBC

EDUFPI

FAC

FCI

FUB

FUBRA

FUP

GRAFUFPI

ICC

IES

IFES

IPTV

ISCSP

MEC

MPDFT

MPOG
Agência Estado

Agência de Comunicação da UFRN

Centro de Comunicação da UFG

Comissão de Ética em Pesquisa

Centro Interdisciplinar em Transporte

Departamento de Ciência da Computação

Conselho Universitário da UFPI

Conselho Universitário

Coordenadoria de Comunicação Social

Centro de Produção Cultural a Educativa

Decanato de Administração

Decanato de Planejamento e Orçamento

Distrito Federal

Ensino a Distância

Empresa Brasil de Comunicação

Editora da Universidade Federal do Piauí

Faculdade de Comunicação

Faculdade de Ciência da Informação

Fundação Universidade de Brasília

Fundação Universitária de Brasília

Faculdade de Planaltina

Gráfica Universitária da UFPI

Instituto Central de Ciências

Instituições de Ensino Superior

Instituições Federais de Ensino Superior

Internet Protocol Television

Instituto Superior de Ciências Sociais e Políticas da

Universidade de Lisboa

Ministério da Educação

Ministério Público do Distrito Federal e Territórios

Ministério do Planejamento, Orçamento e Gestão 
MPT

PDI

PJU

PPGP

RNP

SCS

SCS/UFPI

Secom

Sicap

Supecc/UFES

SINAES

SINTEST-RN

TI

TVU

UFES

UnB

UnBTV

Unitevê

USP

UFF

UFPI

UFRN

UFSCar

VRT

WebRádio

WebTV
Ministério Público do Trabalho

Plano de Desenvolvimento Institucional

Procuradoria Jurídica

Programa de Pós Graduação em Gestão Pública

Rede Nacional de Ensino e Pesquisa

Superintendência de Comunicação Social

Superintendência de Comunicação Social do Piauí

Secretaria de Comunicação Social

Sistema de Cadastramento Unificado de Prestação de Serviço

Superintendência de Cultura e Comunicação

Sistema Nacional de Avaliação da Educação Superior

Sindicato Estadual dos Trabalhadores em Educação do

Ensino Superior (Rio Grande do Norte)

Tecnologia da Informação

TV Universitária

Universidade Federal do Espírito Santo

Universidade de Brasília

Canal Universitário de Brasília

Canal Universitário de Niterói

Universidade de São Paulo

Universidade Federal Fluminense

Universidade Federal do Piauí

Universidade Federal do Rio Grande do Norte

Universidade Federal de São Carlos

Vice-Reitoria

Rádio pela internet

TV pela internet 


\section{SUMÁRIO}

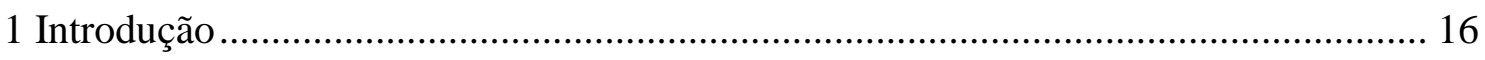

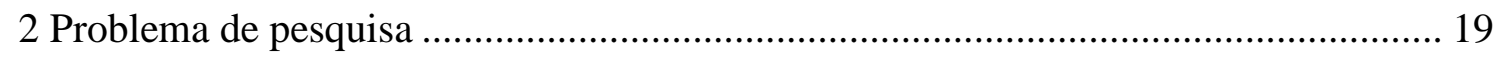

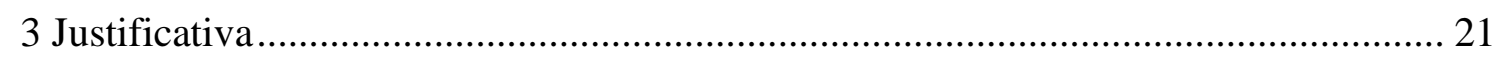

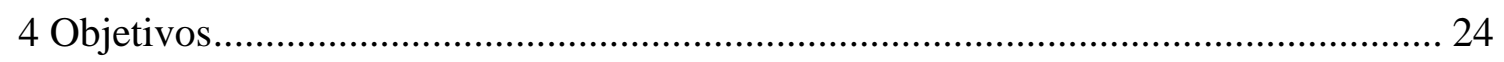

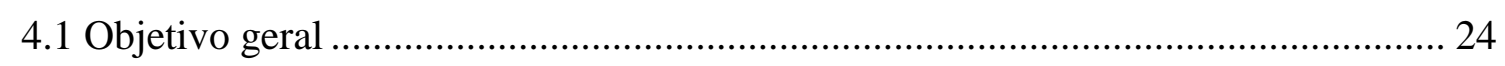

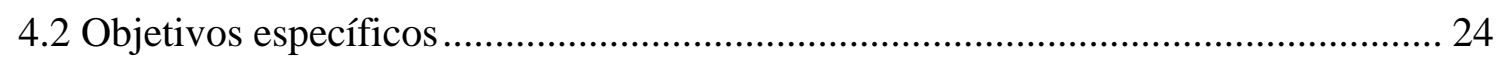

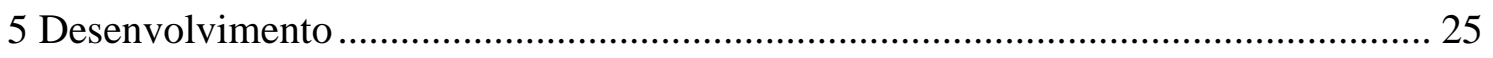

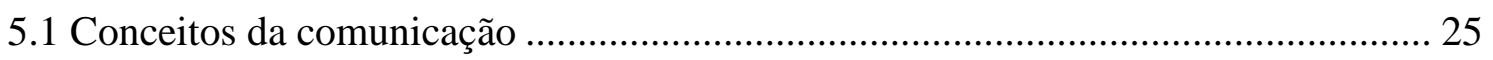

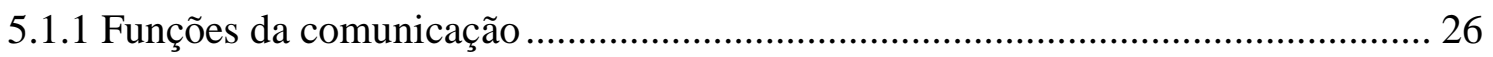

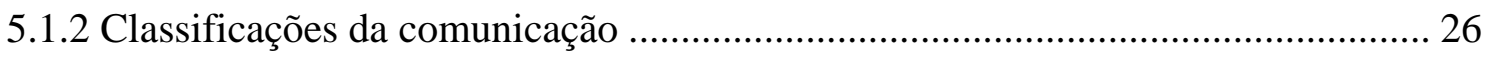

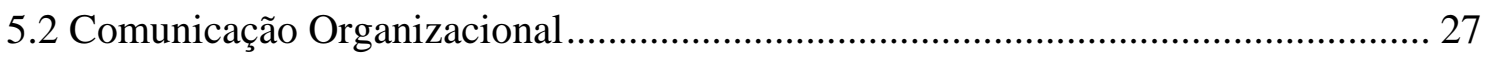

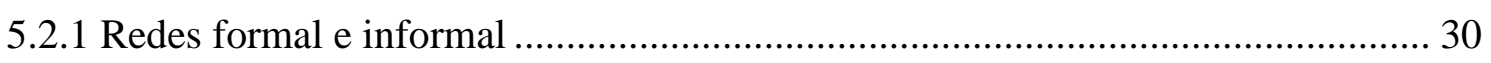

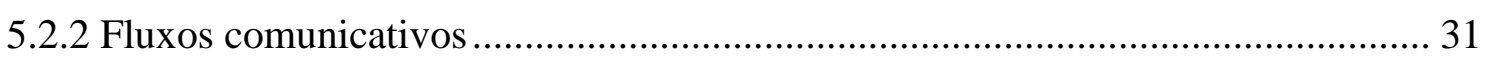

5.2.3 Meios de comunicação nas organizações ................................................................ 32

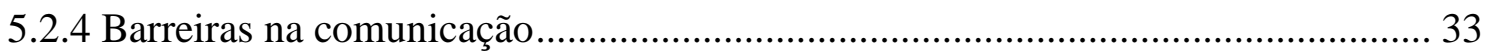

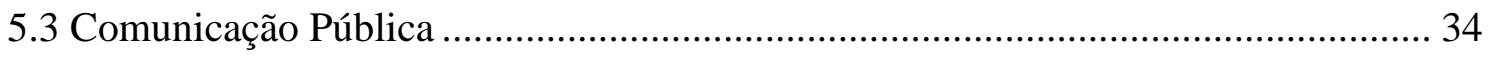

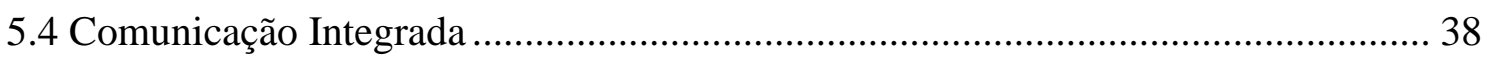

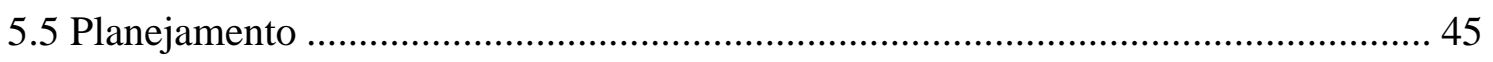

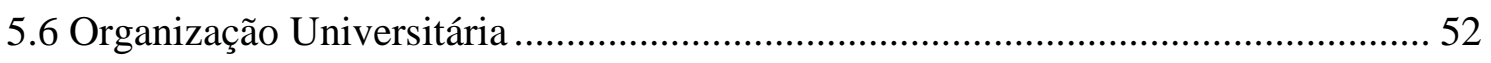

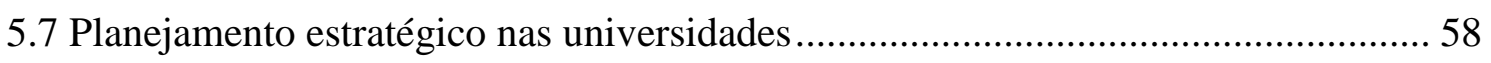

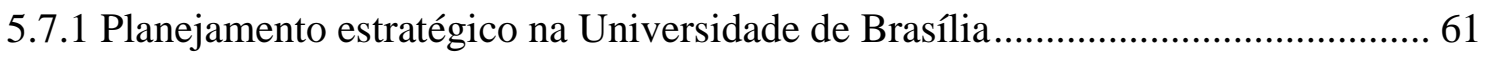

5.8 Comunicação das universidades públicas brasileiras ............................................... 65

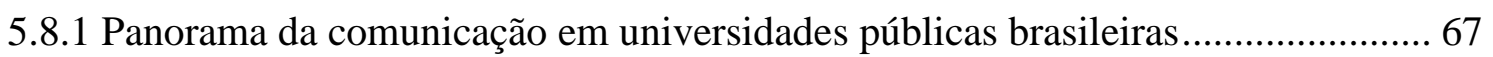

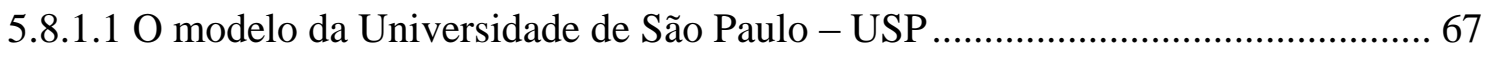

5.8.1.2 O modelo da Universidade Federal Fluminense - UFF ....................................... 69

5.8.1.3 O modelo da Universidade Federal do Espírito Santo - UFES.......................... 71

5.8.1.4 O modelo da Universidade Federal do Piauí - UFPI ......................................... 73

5.8.1.5 O modelo da Universidade Federal do Rio Grande do Norte - UFRN .............. 75

5.9 Estrutura de comunicação da Universidade de Brasília ............................................ 77

5.10 Superintendência de Comunicação da UnB: processo de formação ....................... 87

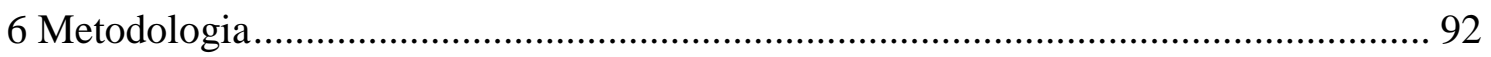

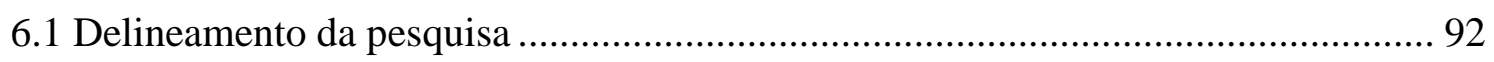




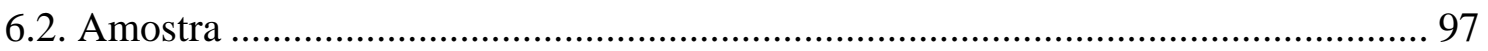

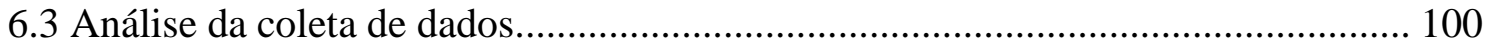

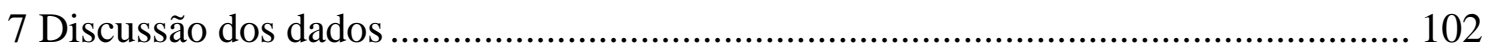

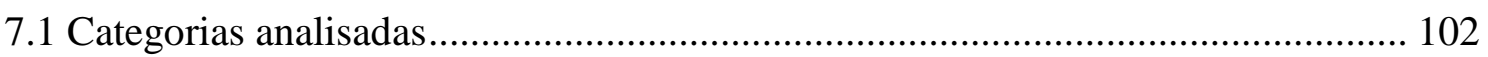

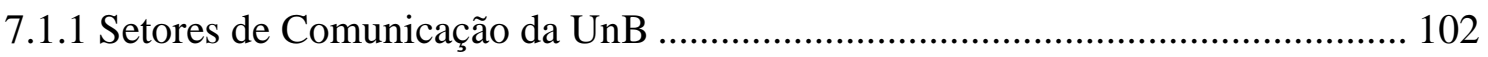

7.1.2 Planejamento da Comunicação da UnB ........................................................... 113

7.1.3 Comunicação Organizacional Integrada........................................................... 122

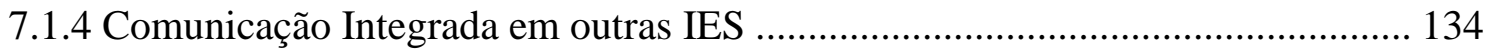

7.1.5 Superintendência de Comunicação da UnB ........................................................ 138

7.2 Conclusões gerais sobre a discussão dos dados ...................................................... 147

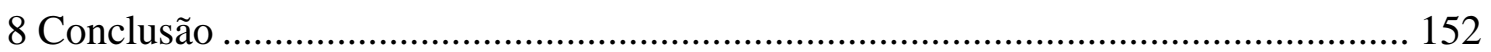

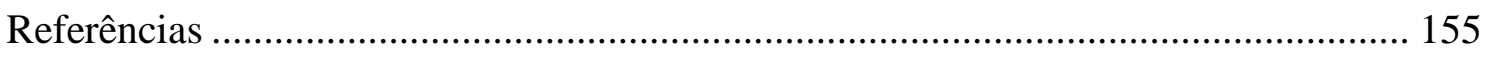

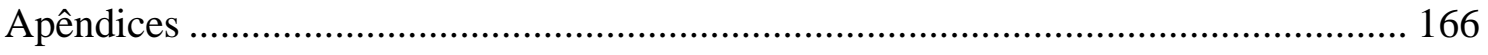

Apêndice A: Termo de consentimento livre e esclarecido dos/as participantes da

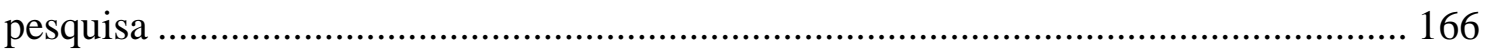

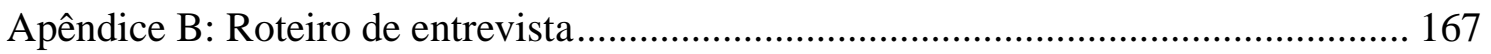

Apêndice C: Adaptação do questionário aos objetivos da pesquisa............................. 169

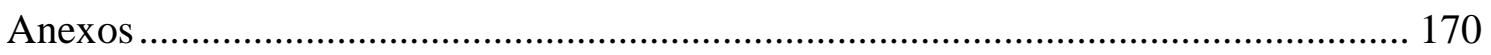

Anexo A: Resolução da Vice-Reitoria n. ${ }^{o}$ 04/2013 .................................................. 170

Anexo B: Resolução da Vice-Reitoria n. ${ }^{\circ}$ 11/2013 ................................................... 171

Anexo C: Memorando sobre o relatório final que estabelece proposta de uma política de

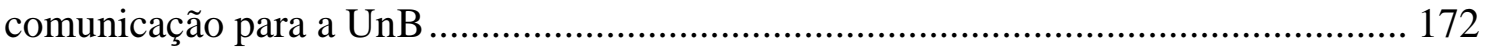

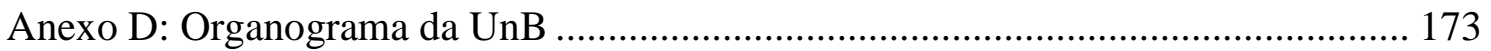

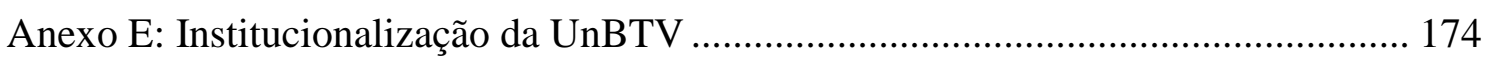

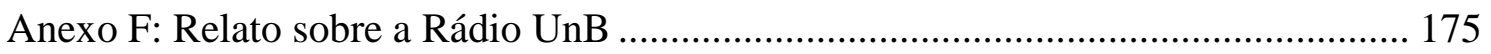

Anexo G: Proposta de Política de Comunicação Integrada para a Universidade de

Brasília. 


\section{Introdução}

"É impossível não se comunicar". Esse axioma da comunicação, formulado pelo pesquisador Paul Watzlawick (1967), significa dizer que estamos sempre comunicando algo, pois, uma vez que não há possibilidade de o ser humano não se comportar, é impossível não comunicar.

Também implica uma pergunta: o que nós e as organizações nas quais atuamos e com as quais interagimos estamos comunicando? Estamos sendo eficazes nesse processo comunicativo? Esse questionamento é importante para a nossa própria sobrevivência e das organizações, bem como para o alcance de novas oportunidades, num mundo em constantes transformações.

No âmbito organizacional, uma visão descuidada da comunicação pode ocasionar o fracasso de programas, recursos humanos e até um desgaste ou a completa ruína da imagem das organizações. Portanto, a comunicação precisa ser pensada como uma filosofia disseminada e utilizada por toda a organização, e não se restringir a algumas iniciativas ou setores.

Nessa linha, Margarida Kunsch (2003) reforça que a organização precisa planejar estrategicamente a sua comunicação. A visão de comunicação integrada adotada pela autora dá o embasamento teórico a este trabalho. Essa percepção busca analisar a comunicação nas e das organizações de forma abrangente, levando em consideração a complexidade do fenômeno comunicacional. Nessa perspectiva, a comunicação deixa de ter uma função apenas tática, para ser considerada estratégica. Para tanto, deve haver a integração entre a comunicação interna, a institucional e a de negócios, na busca da eficácia, eficiência e efetividade. Dessa forma, ganha a organização, os seus públicos e a sociedade (KUNSCH, 2009). 
Estudar, entender e colocar em prática essa nova dimensão da comunicação no interior das organizações é um desafio, ainda mais quando nos referimos às Instituições de Ensino Superior (IES) públicas. Não raro, falta nas universidades uma visão compartilhada e articulada, o que dificulta o processo de planejamento. Kunsch (1992) defende que as universidades brasileiras deveriam repensar todo o seu modelo de comunicação para interagir melhor com a sociedade. No estudo, a autora aponta que, por mais que os dirigentes das IES brasileiras percebam essa necessidade de comunicação, paradoxalmente, a maioria dessas organizações não se organiza de tal modo que consiga realizar esse intento.

A ausência de uma política de comunicação claramente definida compromete também as propostas de mudança, pois a comunidade acadêmica não é envolvida no processo, nem chamada a refletir sobre o significado e o impacto dessas transformações (SCROFERNEKER, 2001).

A Universidade de Brasília (UnB) não é exceção, pois, até o momento, inexiste um plano de comunicação organizacional que estabeleça metas, objetivos e estratégias em um conjunto voltado para os públicos interno e externo, o que tem favorecido ações isoladas. Ao longo do tempo, a UnB estruturou apenas a Secretaria de Comunicação (Secom), mas não conseguiu integrar as áreas de comunicação: UnBTV e Rádio UnB. A distribuição dos setores no organograma da UnB evidencia essa ausência de integração (ANEXO D).

Com o propósito de buscar um plano que articule e integre as unidades de comunicação, a Vice-Reitoria instituiu uma comissão de trabalho, cujo resultado final foi a proposta de criação de uma superintendência de comunicação, a qual será o objeto de estudo da presente dissertação. O aprimoramento da comunicação institucional da UnB, com o estabelecimento de uma política de comunicação integrada, está prevista no Plano de Desenvolvimento Institucional (PDI) da UnB 2014-2017, o qual contempla as bases do 
planejamento estratégico aprovadas pela administração superior (UNIVERSIDADE DE BRASÍLIA, 2015b).

O presente estudo insere-se, portanto, na área de pesquisa Estado, Território e Políticas Públicas do Programa de Pós-Graduação Profissional em Gestão Pública (PPGP/FUP/UnB). Espera-se que os dados coletados possam trazer subsídios para reorientar as estratégias de comunicação e relacionamento com os diversos públicos da Universidade de Brasília (UnB), tendo em vista a necessidade de integração das áreas de comunicação da universidade. 


\section{Problema de pesquisa}

A Universidade de Brasília (UnB) tem mantido uma estrutura de comunicação marcada pela falta de articulação e integração entre as unidades da área e pela ausência de uma política de comunicação global que estabeleça metas, objetivos e estratégias, de modo a ampliar os resultados e garantir uma comunicação eficiente e eficaz com os públicos da instituição.

Diante dessa constatação, percebe-se a necessidade de integrar, de forma harmônica, os diferentes setores de comunicação social da UnB a fim de se obter mais eficiência e sinergia nas ações. Dessa forma, poder-se-ia expor ideias e propostas para solução dos problemas da sociedade e prover meios para viabilizar o acesso da população à produção acadêmica.

O uso sinérgico da comunicação, além de gerar respostas mais imediatas, possibilita a redução substancial de custos, devido ao planejamento e à execução de tarefas conjuntas (TORQUATO DO REGO, 2015). Nesse contexto, é indispensável rever os mecanismos de captação de recursos por parte das unidades de comunicação. Entretanto, verifica-se uma crescente redução e alta rotatividade de profissionais da área na universidade - quer seja pela evasão provocada baixa remuneração e/ou más condições de trabalho, quer seja pela demissão dos trabalhadores terceirizados -, o que contribui para aumentar os entraves administrativos para a execução de projetos com a agilidade e eficiência exigida nesse tipo de atividade.

Nessa perspectiva, a Vice-Reitoria da Universidade de Brasília instituiu, por meio da Resolução n. ${ }^{\circ}$ 04/2013 (ANEXO A) e da Resolução n. ${ }^{\circ}$ 11/2013 (ANEXO B), comissões para apresentar um plano de articulação entre as unidades de comunicação da UnB. Os grupos são formados por representantes das áreas de comunicação da UnB (Rádio, Secom, e UnBTV) e de outros setores da universidade. Vale ressaltar que o estabelecimento de uma política de comunicação integrada no âmbito da Universidade de Brasília está previsto no Plano de 
Desenvolvimento Institucional (PDI) da UnB 2014-2017 e no planejamento estratégico da UnB (UNIVERSIDADE DE BRASÍLIA, 2015b).

A partir do produto dessas comissões, idealizou-se uma política de comunicação integrada para a UnB: uma superintendência, que visa confiar à comunicação da instituição maior coordenação de esforços, aproveitamento das novas tecnologias e a eficiência dos setores de comunicação.

A superintendência objetiva, ainda, por meio da integração, otimizar o atendimento aos públicos internos e externos da universidade para consolidar a imagem da universidade. Assim, indaga-se: como integrar eficientemente os setores de comunicação social da UnB? Essa é a questão norteadora desta dissertação. 


\section{Justificativa}

Esta dissertação pretende pesquisar e analisar uma estrutura unificada de gestão de comunicação organizacional integrada, a partir de uma filosofia que preconiza a convergência de diversas áreas, a fim de permitir uma ação sinérgica:

A convergência de todas as atividades, com base em uma política global, claramente definida e nos objetivos gerais da organização, possibilitará ações estratégicas e táticas de comunicação, mais pensadas e trabalhadas com vistas na eficácia (KUNSCH, 2003, p. 150).

Por essa perspectiva, a comunicação deixa de ser vista como um conjunto de ações isoladas e passa a ser concebida como um processo que necessita de planejamento e direcionamento estratégico, alinhando-se com os objetivos da instituição.

A aplicação da comunicação organizacional integrada nas universidades públicas tem propiciado o surgimento de uma comunicação mais eficiente, ao permitir que os profissionais de áreas específicas trabalhem em torno do mesmo projeto, evitando, assim, a dispersão de recursos humanos e materiais. Também colabora para uniformizar valores e conceitos, além de consolidar a imagem da instituição perante seus públicos interno e externo (KUNSCH, 2003).

As universidades públicas caracterizam-se por uma maior flexibilidade, porém, possuem uma organização conservadora, que necessita de uma estratégia de gestão voltada para o melhor atendimento das demandas da sociedade e da comunidade universitária (MARCELINO, 2004).

A Universidade de Brasília, ao longo dos últimos anos, vem enfrentando sérias dificuldades e restrições institucionais, as quais poderiam ser superadas a partir da implantação de um sistema integrado de planejamento "que atendesse ao planejamento estratégico, tático e operacional" (MIRANDA, 2004, p. 43). 
Nesse contexto, a integração dos setores de comunicação da UnB - Secretaria de Comunicação (Secom), CPCE/UnBTV e Rádio UnB - visa propiciar a construção de uma linguagem uníssona e um comportamento afinado, a fim de possibilitar a otimização de esforços e evitar sobreposições de tarefas. Os setores podem trabalhar de forma conjunta, a partir dos objetivos da instituição e respeitando as metas de cada um, promovendo uma gestão orientada ao público usuário.

A integração desses setores está prevista no Plano de Desenvolvimento Institucional (PDI) da UnB 2014-2017 e no planejamento estratégico da UnB (UNIVERSIDADE DE BRASÍLIA, 2015b).

Note-se que a atuação isolada tem sido favorecida pela ausência de uma política de comunicação estratégica para a UnB. Cada unidade estabelece sua proposta de orçamento para determinado plano de ação e a encaminha individualmente à Reitoria ou ao Decanato de Administração (DAF/UnB), podendo precarizar, assim, a gestão do financiamento da comunicação social da universidade. Dessa forma, a sobrevivência financeira dessas unidades de comunicação dependem, em grande parte, do protagonismo dos seus gestores.

Do ponto de vista administrativo, as unidades enfrentam entraves que impedem o seu desenvolvimento consistente. Entre eles, encontram-se a crescente redução do número de profissionais - devido à alta rotatividade e à baixa remuneração - e a substituição destes por estagiários de graduação, conforme consta no Relatório de Autoavaliação Institucional da Universidade de Brasília 2012 (UNIVERSIDADE DE BRASÍLIA, 2014b).

Vale registrar, como outro aspecto deficiente, a defasagem tecnológica dos equipamentos e de infraestrutura, o que compromete a qualidade no tratamento da informação na UnB.

Do mesmo modo, unidades com perfil de órgão complementar, como o CPCE/UnBTV, buscam recursos por meio de projetos, mas esbarram em dificuldades 
administrativas para executá-los de forma adequada. Muitos projetos acabam sendo desenvolvidos por iniciativa dos gestores das unidades ante a existência de oportunidades, em vez de serem fomentados por uma política institucional. Portanto, pretende-se pesquisar em que aspectos uma política de gestão para o setor permitirá a articulação, integração e o fortalecimento da comunicação social da UnB.

Aliado a isso, verifica-se a carência de estudos e diagnósticos que descrevam o perfil dos públicos interno e externo de interesse da instituição. Os dados coletados nesta pesquisa podem ajudar a aperfeiçoar os veículos existentes e reorientar as estratégias de comunicação e relacionamento com esses públicos.

Ao analisar a proposta de política de comunicação organizacional integrada para a UnB, no contexto da Resolução n. ${ }^{\circ}$ 04/2013 da VRT/UnB, o presente estudo concluiu que a criação de um órgão como uma superintendência de comunicação pode levar a uma melhor gestão da comunicação da UnB. 


\section{Objetivos}

\subsection{Objetivo geral}

Analisar como a comunicação organizacional da UnB pode integrar os setores de comunicação social da universidade, no âmbito da proposta da comissão instituída pela Resolução n. ${ }^{\circ}$ 04/2013, da Vice-Reitoria da UnB.

\subsection{Objetivos específicos}

- Analisar o cenário atual da gestão da comunicação na UnB.

- Examinar o panorama do planejamento estratégico aplicado à comunicação organizacional no âmbito das universidades públicas brasileiras, em especial da UnB.

- Investigar a comunicação organizacional integrada e os desafios para a integração dos setores de comunicação da UnB.

- Relacionar experiências de gestão integrada no âmbito da comunicação de universidades públicas brasileiras com o processo de construção de uma política de comunicação integrada na UnB.

- Analisar o modelo proposto de Superintendência de Comunicação na UnB. 


\section{Desenvolvimento}

\subsection{Conceitos da comunicação}

A comunicação humana costura a teia social, pois é por meio da linguagem que construímos uma realidade compartilhada, base para a vida social (CASTRO, V., 1998). Por meio dos processos comunicativos, são criadas as bases de entendimento que permitem às pessoas interagirem como grupos organizados, visando alcançar objetivos pré-determinados.

A palavra comunicação origina-se do latim communis, comum. Portanto, etimologicamente comunicar significa tornar algo comum entre as pessoas; introduz a ideia de comunhão, comunidade (MARQUES DE MELO, 1975; SOUSA, 2006). Para Freire (1977, p. 67), comunicação implica reciprocidade: “o que caracteriza a comunicação enquanto este comunicar comunicando-se é que ele é diálogo, assim como o diálogo é comunicativo". Na concepção desse autor, comunicação significa coparticipação dos sujeitos pensantes, que juntos criam o conhecimento, transformando e humanizando o mundo.

O ato de comunicar está presente nas mais variadas formas de interação social, envolvendo poder, consentimento, cooperação, liderança e solidariedade (KATZ; KAHN, 1978). Em tempos de novas tecnologias e intensas interações, comunicar é cada vez menos transmitir e cada vez mais negociar e conviver (WOLTON, 2010).

A comunicação pode ser analisada sob dois aspectos: como processo ou como atividade social. No primeiro caso, o foco é no canal e na troca de mensagens codificadas dos comunicadores em um determinado contexto. Nesse caso, comunicar significa observar "os acontecimentos e as relações como dinâmicos, em evolução, sempre em mudança, contínuos" (BERLO, 2003, p. 23). Esse processo comunicacional é compreendido por diversos teóricos da comunicação como complexo, ubíquo e multidisciplinar (LITTLEJOHN, 1988; KREEPS, 1995; MARCHIORI, 2010). 
Já na comunicação como atividade social, a ênfase recai sobre como as pessoas respondem à realidade, interagindo por meio da troca de significados, em uma dada cultura. A comunicação é, assim, um fator essencial de integração (BUONO; BOWDITCH, 1992).

O estudo da comunicação situa-se, primordialmente, nos campos das ciências humanas e sociais, mas não é exclusivo dessas áreas, pois tem recebido contribuições de diferentes ciências. Dessa forma, a comunicação é compreendida como uma ciência multidisciplinar.

\subsubsection{Funções da comunicação}

Robbins (2002) aponta quatro funções da comunicação: controle, motivação, expressão emocional e informação. A comunicação atua no controle do comportamento das pessoas de várias formas, a começar pela hierarquia, fazendo com que os integrantes da organização saibam a quem comunicar primeiro uma informação ou um acontecimento. A comunicação facilita também a motivação, na medida em que esclarece o que deve ser feito, avalia a qualidade do seu desempenho e orienta sobre o que fazer para melhorá-lo. Por meio da expressão emocional, os funcionários expressam os seus sentimentos de satisfação e/ou frustrações. Por fim, a comunicação facilita a tomada de decisões, porque proporciona aos indivíduos e ao grupo as informações que necessitam para a tomada de decisões (ROBBINS, 2002).

\subsubsection{Classificações da comunicação}

Torquato do Rego (2015) classifica os tipos de comunicação em três dimensões: 1) comportamental (níveis intrapessoal, interpessoal e grupal); 2) social, o qual envolve a organização e o sistema social, e 3) cibernética, que agrupa circuitos de captação, armazenamento, tratamento e disseminação de informações no âmbito organizacional. A primeira dimensão está relacionada ao comportamento no interior das organizações, 
envolvendo as preocupações com processos e habilidades comunicativas entre indivíduos e grupos, "com a finalidade de ajustamento, integração e desenvolvimento". A segunda dimensão ocorre por meio da comunicação de massa, caracterizada pela transmissão de mensagens de uma fonte para uma ampla audiência, "heterogênea, dispersa e amorfa". Já a terceira dimensão diz respeito ao controle, tratamento das informações, seu armazenamento por máquinas, "e vincula-se ao sistema tecnológico das organizações" (TORQUATO DO REGO, 2015, p. 66).

Rogério Santos (1998), por sua vez, divide a comunicação em interpessoal, de massas e organizacional. Segundo o autor, a comunicação interpessoal é a forma mais simples de interação, entre pelo menos duas pessoas. Trata-se de um processo dialógico, base da comunicação humana. Já a comunicação de massas é aquela em que o emissor organiza, elabora e distribui a informação para uma vasta audiência. A comunicação organizacional, por sua vez, ocorre dentro de uma estrutura ou grupo coerente, visando a um objetivo comum (SANTOS, 1998).

A principal diferença entre esses três modos de comunicação está na relação entre os seus intervenientes e é essencial para identificar a eficácia da comunicação. Dessa forma, pela análise das ações e reações do emissor-receptor é possível saber se a comunicação atinge os seus objetivos, se é ou não persuasiva (SANTOS, 1998).

Na próxima seção, será abordada a comunicação no âmbito das organizações, objeto do presente estudo.

\subsection{Comunicação Organizacional}

A comunicação organizacional envolve os diversos instrumentos utilizados pela organização para interagir com os seus diferentes públicos (SCROFERNEKER, 2000) e com a sociedade em geral, criando mecanismos para a validação pública de sua atuação (OLIVEIRA; PAULA, 2007). 
Conforme Duarte e Monteiro (2009, p. 334), a comunicação é a própria “energia que circula nos sistemas e a argamassa que dá consistência à identidade organizacional. Ela é o oxigênio que dá vida às organizações”. Dessa forma, o sistema de comunicação é vital para o processamento das funções administrativas internas e do relacionamento com o meio externo à organização (KUNSCH, 2003).

A comunicação organizacional pode ser entendida como um processo que intermedeia o discurso da organização, ajusta interesses, controla os participantes internos e externos e promove maior aceitabilidade da ideologia organizacional. Envolve, dessa forma, a interpretação e negociação de mensagens, por meio de esforços para articular e trazer a compreensão mútua das visões, propósitos e metas da organização entre os funcionários (TORQUATO DO REGO, 2015; ANDREWS; HERSCHEL; BAIRD, 1996).

Segundo Freitas (2004, p. 41), a comunicação estabelece o diálogo da organização em âmbito interno e externo.

\begin{abstract}
Em âmbito interno o diálogo se configura em consonância com a cultura organizacional. Neste sentido, a comunicação é apontada como poder para facilitar a cooperação, a credibilidade e o comprometimento com valores. O relacionamento da organização no âmbito externo será o reflexo do tratamento da comunicação em âmbito interno.
\end{abstract}

Verificam-se, portanto, duas perspectivas complementares da comunicação organizacional: a comunicação interna, em que estão envolvidos os integrantes da organização, e a comunicação externa, em que o corpo organizacional interage com o meio em que está inserido.

Para Cardoso (2006, p. 1.132), não existe organização sem prática comunicativa. O autor afirma que esses processos comunicativos

(...) são essenciais para a operação da entidade e estão intimamente vinculados às formas de significar, valorar e expressar uma organização, isto é, ao processo comunicacional e constitutivo da cultura da organização, e de sua identidade, configurando imagens reconhecidas por seus diversos públicos internos e externos. A comunicação pode ser entendida, então, como um alicerce que dá forma à organização, fazendo-a ser aquilo que ela é. 
Conforme Cardoso (2006), a comunicação organizacional atravessa todas as ações de uma empresa ou organização, atuando de forma permanente na construção de sua cultura e identidade. O autor adota o termo comunicação organizacional em substituição ao conceito tradicional de comunicação empresarial.

Cardoso (2006, p. 1.140) explica que a comunicação organizacional diz respeito a uma visão mais estratégica da comunicação, enquanto a comunicação empresarial relacionase a uma abordagem instrumental da comunicação.

A comunicação organizacional vem assumindo uma nova dimensão estratégica nas organizações que, como se vê, modifica paulatinamente antigos limites. A comunicação assume um papel muito mais abrangente, fazendo referência a tudo que diz respeito à posição social e ao funcionamento da organização, que envolve desde seu clima interno até suas relações institucionais.

Torquato do Rego (2015, p. 14) também passou a adotar o termo comunicação organizacional, em vez de comunicação empresarial: "trata-se, afinal, de reconhecer a irrefutável realidade: a comunicação resvalou para outros terrenos e espaços, ampliando o escopo e adicionando novos campos ao território da comunicação empresarial”.

Kunsch (2009) enfatiza que a comunicação organizacional precisa ser entendida de forma ampla: "Pode-se dizer que é uma disciplina que estuda como se processa o fenômeno comunicacional dentro das organizações e todo o seu contexto político, econômico e social" (KUNSCH, 2009, p. 54).

Hall (1984, p. 132) ressalta que o processo de comunicação nas organizações “contém elementos que são fortemente organizacionais e fortemente individuais". Pinho (2006, p. 27) reforça essa ideia ao afirmar que, "independentemente do tipo de organização, a comunicação é o elemento que mantém e sustenta os relacionamentos no ambiente organizacional".

Kreeps (1995) entende a comunicação organizacional como um processo marcado pelo recebimento e geração de informações. Nessa perspectiva, a comunicação organizacional 
assume a função de fonte informacional para os membros de uma determinada organização. A informação se constitui, assim, em uma ponte entre a comunicação e a organização. O autor identifica nas organizações quatro níveis hierárquicos de comunicação humana: comunicação intrapessoal, comunicação interpessoal, comunicação de grupos pequenos e comunicação de grupos múltiplos. A comunicação intrapessoal é a forma mais extensa e básica da comunicação humana, na qual é processada a informação. A comunicação interpessoal se constrói sobre o nível intrapessoal, entre duas pessoas. Já a comunicação de grupos pequenos constrói-se sobre a interação interpessoal, utilizando vários comunicadores e somando dinâmicas grupais e relações interpessoais. A comunicação de multigrupos se dá por meio da combinação dos outros três níveis de comunicação, ao coordenar um grande número de pessoas para cumprir os objetivos em comum (KREEPS, 1995).

\subsubsection{Redes formal e informal}

Segundo Kunsch (2003, p. 84), a comunicação nas organizações flui, de forma simultânea, por meio de duas redes: formal e informal. A comunicação formal é aquela procedente da própria estrutura organizacional, "de onde emana um conjunto de informações, pelos mais diferentes veículos”.

Trata-se da comunicação administrativa, que se relaciona com o sistema expresso de normas que regem o comportamento, os objetivos, as estratégias e conduzem as responsabilidades dos integrantes das organizações (KUNSCH, 2003, p. 84).

Já a comunicação informal é aquela que surge das relações entre as pessoas. A autora aponta como um dos principais produtos da rede informal a "rede de boatos", decorrente, em grande parte, "da ansiedade, da insegurança e da falta de informações". Outros exemplos são a conversa e a livre manifestação dos trabalhadores, que fazem parte do convívio das pessoas (KUNSCH, 2003, p. 83). 
O sistema formal de comunicação de toda organização - o conjunto de canais e meios de comunicação estabelecidos de forma consciente e deliberada - é suplementada, no decorrer de pouco tempo, por uma rede informal de comunicações, igualmente importante, que se baseia nas relações sociais intraorganizativas e é uma forma mais rápida de atender a demandas mais urgentes e instáveis (KUNSCH, 2003, p. 82).

Para a pesquisadora, a comunicação informal precisa ser canalizada para o "lado construtivo", auxiliando a organização a buscar respostas de forma mais rápida às inquietações do meio e facilitando a gestão das pessoas, visando a uma administração participativa (KUNSCH, 2003, p. 84).

Torquato do Rego (2015) avalia que a construção de um modelo sinérgico de comunicação depende do estudo dessas redes, as quais são fontes importantes para a construção um modelo avançado de comunicação a serviço de organizações complexas.

No item a seguir serão analisadas as formas como a comunicação flui dentro da organização.

\subsubsection{Fluxos comunicativos}

Os fluxos mais citados em pesquisas da área de comunicação organizacional são os descendentes ou verticais, os ascendentes e os horizontais ou laterais.

Kunsch (2003) explica que a comunicação descendente ou vertical é aquela ligada ao processo de informações da cúpula da organização para os subalternos na hierarquia, caracterizando-se como comunicação administrativa oficial. Já a comunicação ascendente é o processo oposto: as informações são enviadas de baixo para cima, por meio de instrumentos planejados (caixa de sugestões, reuniões com trabalhadores e sistemas de consulta). No fluxo horizontal ou lateral, a comunicação se dá no mesmo nível.

No fluxo descendente, o objetivo é a difusão dos dados globais, tais como as políticas da organização, dentre outras informações, tendo como característica a formalidade. 
O fluxo ascendente permite que os dados recolhidos nas bases cheguem até as instâncias superiores e departamentos interessados (BALDISSERA, 2000).

A comunicação horizontal possibilita o entrosamento nos grupos de pares e de mesmo nível funcional, contribuindo para o aprimoramento da coordenação (TORQUATO DO REGO, 2015). Segundo Faria e Suassuna (1982, p. 120), o fluxo horizontal permite que o administrador alcance "a coordenação de esforços, capaz de proporcionar a imprescindível sinergia, e o controle, por meio de comunicações feitas por relatórios e gráficos da infra para a superestrutura".

Gaudêncio Torquato do Rego (1986, p. 54) enfatiza:

Nos desenhos organizacionais mais autoritários e hierárquicos, percebe-se uma tendência para se manter a informação como propriedade secreta de alguns grupos, que, evidentemente, utilizam esse propriedade para controlarem os subalternos.

Kunsch (2003, p. 86) acrescenta os fluxos transversal ou longitudinal e o circular. A comunicação transversal é aquela que perpassa todas as instâncias e variados setores.

\footnotetext{
Uma tendência das organizações orgânicas e flexíveis é permitir que a comunicação ultrapasse as fronteiras tradicionais do tráfego de suas informações. Essas organizações, por incentivarem uma gestão mais participativa e integrada, criam condições para que as pessoas passem a intervir em diferentes áreas e com elas interagir.
}

Já o fluxo circular surge e se desenvolve em organizações informais e favorece a efetividade do trabalho.

Para viabilizar a comunicação com os variados públicos, no nível descendente, as organizações utilizam diversos instrumentos, conforme será exposto a seguir.

\subsubsection{Meios de comunicação nas organizações}

Os canais mais usados na comunicação descendente são: visuais - escritos (instruções, circulares, manuais, boletins, panfletos, jornais e outros), pictográficos (pinturas, fotografias, desenhos, diagramas e mapas), escrito-pictográficos (cartazes, filmes mudos com 
legenda, gráficos, diplomas e certificados) e simbólicos (luzes, bandeiras e flâmulas e insígnias); auditivos - diretos (conversas, entrevistas, reuniões e conferências), indiretos (telefone, rádio, intercomunicadores automáticos e autofalantes) e simbólicos (sirenes, apitos, sinos e outros); audiovisuais (filmes, demonstrações, vídeo, videoconferência e outros); telemáticos (internet, intranet, celulares e outros) e meio presencial direto (comunicação participativa, como o teatro). Portanto, a maior parte da comunicação no âmbito das organizações apoia-se em canais orais e escritos (TORQUATO DO REGO, 1986, p. 65; KUNSCH, 2003, p. 87).

Na utilização desses instrumentos, a organização precisa estar atenta para evitar ruídos no processo de comunicação.

\subsubsection{Barreiras na comunicação}

No processo comunicacional, "ruídos" podem interferir e comprometer a eficácia da comunicação. Segundo Kunsch (2003), as barreiras mais comuns são de natureza mecânica, fisiológica, semântica e psicológica. As barreiras mecânicas ou físicas relacionam-se com os aparelhos de transmissão que podem dificultar ou mesmo bloquear a comunicação. As barreiras fisiológicas decorrem de problemas genéticos ou malformação de órgãos vitais para a comunicação. As barreiras semânticas são ocasionadas pelo uso inadequado da linguagem, quando os códigos e signos empregados não fazem parte do repertório estabelecido em um ambiente comunicacional. Por fim, as barreiras psicológicas são os preconceitos e estereótipos que prejudicam a comunicação. Estão relacionados a percepções equivocadas, a partir de atitudes, crenças, valores e cultura da pessoa (KUNSCH, 2003).

No contexto das organizações, a autora destaca quatro barreiras: pessoais, administrativas, excesso de informações e as informações incompletas. As barreiras pessoais dizem respeito à personalidade de cada indivíduo, como este se comporta no ambiente de trabalho. As barreiras administrativas decorrem das formas como as organizações atuam e 
processam as informações. A sobrecarga de informações é gerada pela falta de seleção e de prioridade, o que prejudica a eficiência e a eficácia da comunicação. Já as comunicações incompletas e parciais são provocadas por informações fragmentadas, distorcidas ou duvidosas (KUNSCH, 2003).

As considerações ora expostas sobre comunicação no âmbito das organizações representam, de forma sintética, a base dos estudos sobre o tema. No próximo tópico serão analisados aspectos relacionados à comunicação em organizações públicas.

\subsection{Comunicação Pública}

O conceito de comunicação pública varia de acordo com o ponto de vista dos estudiosos do assunto. Para Elizabeth Pazito Brandão (2007), essa pluralidade de definições demonstra que a expressão não é um conceito claro, nem ainda uma área profissional bem delimitada.

A autora citada identificou o uso do termo em vários campos do conhecimento e agrupou-os em cinco áreas. A primeira área está associada à atuação da comunicação organizacional. Nesse enfoque, a comunicação pública é empregada ao lado dos conceitos organizacionais: planejamento estratégico da comunicação nas instituições e definição dos objetivos que orientam a atuação junto aos seus diversos públicos, visando ao desenvolvimento da sua imagem institucional. Para tanto, utilizam-se os variados instrumentos e técnicas de marketing e comunicação organizacional.

A segunda área identifica a comunicação pública com a comunicação científica. Nesse campo, busca-se a aproximação da ciência com a sociedade, por meio das diversas tecnologias de informação e divulgação do conhecimento. Nessa perspectiva, a comunicação pública pretende influenciar na mudança de hábitos da população, bem como na tomada de decisões políticas sobre assuntos da ciência que impactam de forma direta na vida dos cidadãos. 
Na terceira área, Brandão (2007, p. 5) correlaciona a comunicação pública com a comunicação do Estado e/ou governamental. Nessa ótica, a comunicação pública é compreendida "como um processo comunicativo das instâncias da sociedade que trabalham com a informação voltada para a cidadania". A autora destaca que a comunicação governamental pode ser identificada como comunicação pública na medida em que se torna um instrumento de construção da agenda pública, direcionando o governo para a prestação de contas e, ao mesmo tempo, possibilitando a participação da população nas políticas e nos debates públicos.

A quarta área relaciona a comunicação pública com a comunicação política. Brandão (2007) faz esse paralelo a partir de dois pontos de vista: o primeiro diz respeito à expressão dos partidos políticos e dos governos, na medida em que utilizam meios comunicacionais para transmitir, na esfera pública, seus ideais partidários e posicionamentos políticos; já o segundo refere-se à mediação e discussão entre os detentores da tecnologia e dos veículos de comunicação e a sociedade civil - que busca interferir no acesso a essas tecnologias, bem como na regulação e escolha do conteúdo. Nesse caso, cabe ao Estado a gestão desse diálogo e a responsabilidade pelas questões concernentes às políticas públicas de comunicação.

Por último, a autora identifica a comunicação pública com estratégias da sociedade civil organizada. Nesse contexto, entende-se que o governo não é o único responsável pela definição das políticas públicas. Aqui, a comunicação pública é utilizada como referência a uma prática democrática de comunicação, independente da grande indústria midiática e comprometida com o cotidiano das populações.

Brandão (2007, p. 9) aponta um ponto em comum entre as diferentes interpretações da expressão "comunicação pública", que é aquele relacionado à participação dos atores envolvidos - Estado, governo e sociedade - com o propósito de "informar para a construção da cidadania". 
Para Graça Monteiro (2007), comunicação pública divide-se em quatro modalidades: 1) comunicação institucional, responsável por divulgar o papel das organizações, prestando contas de suas atividades; 2) comunicação governamental, praticada pelo governo, nas diferentes esferas, para prestação de contas e estímulo da participação popular nas políticas; 3) comunicação política, relacionada aos processos eleitorais; e 4) comunicação pública propriamente dita, relacionada às obrigações da instituição pública, como informar o público, apresentar e promover os serviços de administração e tornar conhecidas as instituições interna e externamente.

Monteiro ressalta que a comunicação pública não é exclusiva das instituições governamentais, "é feita também por movimentos sociais e organizações do terceiro setor e ainda por empresas privadas cujas ações sociais transcendem os limites dos negócios privados" (MONTEIRO, 2007, p. 39).

Para Matos (2007, p. 52), o conceito de comunicação pública é indissociável dos agentes envolvidos na comunicação.

\footnotetext{
Se historicamente este ou aquele agente possa ter se confundido com o processo mesmo da comunicação pública, como foi e continua sendo o caso do Governo e das mídias, é preciso superar este estágio, propondo um novo paradigma: a comunicação pública exige a participação da sociedade e seus segmentos.
}

Novelli (2006, p. 77), por sua vez, destaca a importância da comunicação pública para o exercício da participação popular e da cidadania. Nesse sentido, cabe à comunicação pública "extrapolar a esfera da divulgação de informações do governo e da assessoria de imprensa como mecanismo de autopromoção dos governantes e de suas ações para colocar-se como instrumento facilitador do relacionamento entre cidadão e Estado".

Ainda na percepção da autora, a comunicação pública tem papel essencial para o desempenho de uma boa administração.

É nessa perspectiva que Brandão (2007, p. 24) conceitua comunicação pública como "um processo que se instaura na esfera pública entre o Estado, o Governo e que se propõe a 
ser um espaço privilegiado de negociação entre os interesses das diversas instâncias de poder constitutivas da vida pública no país".

Na mesma linha, Duarte (2015, p. 2) considera que a comunicação pública "trata de compartilhamento, negociações, conflitos e acordos na busca do atendimento de interesses referentes a temas de relevância coletiva".

Conforme Duarte (2015, p. 2), comunicação governamental diz respeito a fluxos de informação e padrões de relacionamento que envolvem os gestores e a ação do Estado e a sociedade. "O Estado, nesse caso, é compreendido como o conjunto das instituições ligadas ao Executivo, Legislativo e Judiciário, incluindo empresas públicas, institutos, agências reguladoras, área militar e não deve ser confundido com governo”.

Kunsch (2013) percebe a comunicação pública como uma necessidade e uma obrigação, tendo em vista que a razão de ser do serviço público são o cidadão e a sociedade. Segundo a autora, é preciso uma mudança cultural de mentalidade, tanto do serviço público quanto da sociedade, para resgatar a legitimidade do poder público. Kunsch (2013) aponta a necessidade de as ações comunicativas contribuírem para uma sociedade mais justa. Para tanto, a autora ressalta que a comunicação deve ser vista como uma prioridade das instituições públicas; além disso, os servidores públicos e os gestores devem estar preparados e engajados para uma comunicação proativa.

Para a melhoria da comunicação nas organizações públicas, Kunsch (2013) afirma que é preciso enfrentar algumas barreiras, tais como: os estereótipos sobre o serviço público, o culto excessivo à burocracia, o ceticismo do servidor público, as ingerências políticas, o imediatismo e a improvisação das ações comunicativas, a falta de recursos financeiros e a não-profissionalização (cargos políticos).

De forma esquemática, Torquato do Rego (2002) apresenta um roteiro para o desenvolvimento da comunicação no âmbito do serviço público. O autor aponta dez funções: 
1) comunicação como forma de integração interna, visando dar conhecimento, motivar e integrar setores para a consecução de objetivos; 2) comunicação como forma de expressão de identidade, para construir e resguardar a imagem e a credibilidade; 3) comunicação como base de lançamento de valores; 4) comunicação como base da cidadania, para permitir o direito à informação; 5) comunicação como função orientadora do discurso dos dirigentes; 6) comunicação como forma de orientação aos cidadãos; 7) comunicação como forma de mapeamento dos interesses sociais, a partir do estudo e planejamento; 8) comunicação como forma de democratização do poder, a partir do compartilhamento de mensagens; 9) comunicação como forma de integração social, para integrar as comunidades e uni-las em torno de um ideal; e 10) comunicação como instrumento a serviço da verdade, relacionada à ética.

O próximo segmento será voltado para o estudo da comunicação integrada no âmbito das organizações.

\subsection{Comunicação Integrada}

O conceito de comunicação integrada adotado por este estudo parte da concepção teórica desenvolvida por Margarida Kunsch (2003). Conforme a autora, a comunicação integrada é "uma filosofia que direciona a convergência das diversas áreas, permitindo uma atuação sinérgica" (KUNSCH, 2003, p. 150).

Nessa perspectiva, a comunicação organizacional integrada pressupõe uma "junção da comunicação institucional, da comunicação mercadológica, da comunicação interna, e da comunicação administrativa, que formam o mix, o composto da comunicação organizacional" (KUNSCH, 2003, p. 150).

Essa concepção procura ver a comunicação nas e das organizações em uma visão abrangente, considerando todos os aspectos relacionados com a complexidade do processo comunicacional. 
Torquato do Rego (2015, p. 17) entende que é essencial uma coordenação centralizada para a eficiência e a eficácia da comunicação no âmbito das organizações: "o importante é procurar considerar a comunicação uma ação integrada de meios, formas, recursos, canais e intenções”.

Bueno (2002, p. 8), por sua vez, conceitua comunicação integrada como um

(...) conjunto articulado de esforços, ações, estratégias e produtos de comunicação, planejados e desenvolvidos por uma empresa ou entidade, com o objetivo de agregar valor à sua marca ou de consolidar a sua imagem junto a públicos específicos ou à sociedade como um todo.

Nessa direção, Kotler (2008, p. 42) esclarece que a comunicação integrada deve:

(...) reconhecer o valor agregado de um plano abrangente, avaliar os papéis estratégicos de uma variedade de disciplinas de comunicações e combinar essas disciplinas para fornecer clareza, consistência e impacto máximo de comunicação por meio da integração de mensagens discretas.

Para Elen Geraldes (2014), a comunicação integrada pressupõe que as várias habilitações que compõem a área, "com suas competências e olhares específicos", devem trabalhar em conjunto, agindo de forma transdisciplinar. Ainda segundo a autora, a comunicação integrada pode ser vista de outro ponto de vista.

É a indissociabilidade entre tática, estratégia e políticas, constituindo uma Comunicação que, além de ser pautada pelo cenário e suas exigências, com um foco na sustentabilidade, elabora seus produtos e processos a partir de valores, princípios, identidade e memória (GERALDES, 2014, p. 138).

A comunicação integrada é analisada por Oliveira e Paula (2007) pela ótica das interações estabelecidas pela organização com os seus interlocutores. As autoras propõem um modelo de comunicação dialógica, com fluxos planejados e espontâneos, informacionais e relacionais, da organização com os diversos atores sociais. Nesse contexto, a ênfase deslocase da convergência de esforços para uma percepção da comunicação como um processo que institui espaços comuns, em que ocorre o compartilhamento de significados e construção de sentidos entre os interlocutores. 
Kunsch (2003) utiliza um modelo mais didático, o qual aponta as grandes áreas da comunicação organizacional integrada, que permitem a uma organização interagir com os seus públicos-alvo e com a sociedade em geral, a partir de uma ação conjugada de esforços: a comunicação administrativa, a comunicação interna, a comunicação mercadológica e a comunicação institucional.

A Figura 1 indica essa visão:

Figura 1 - Comunicação Organizacional Integrada

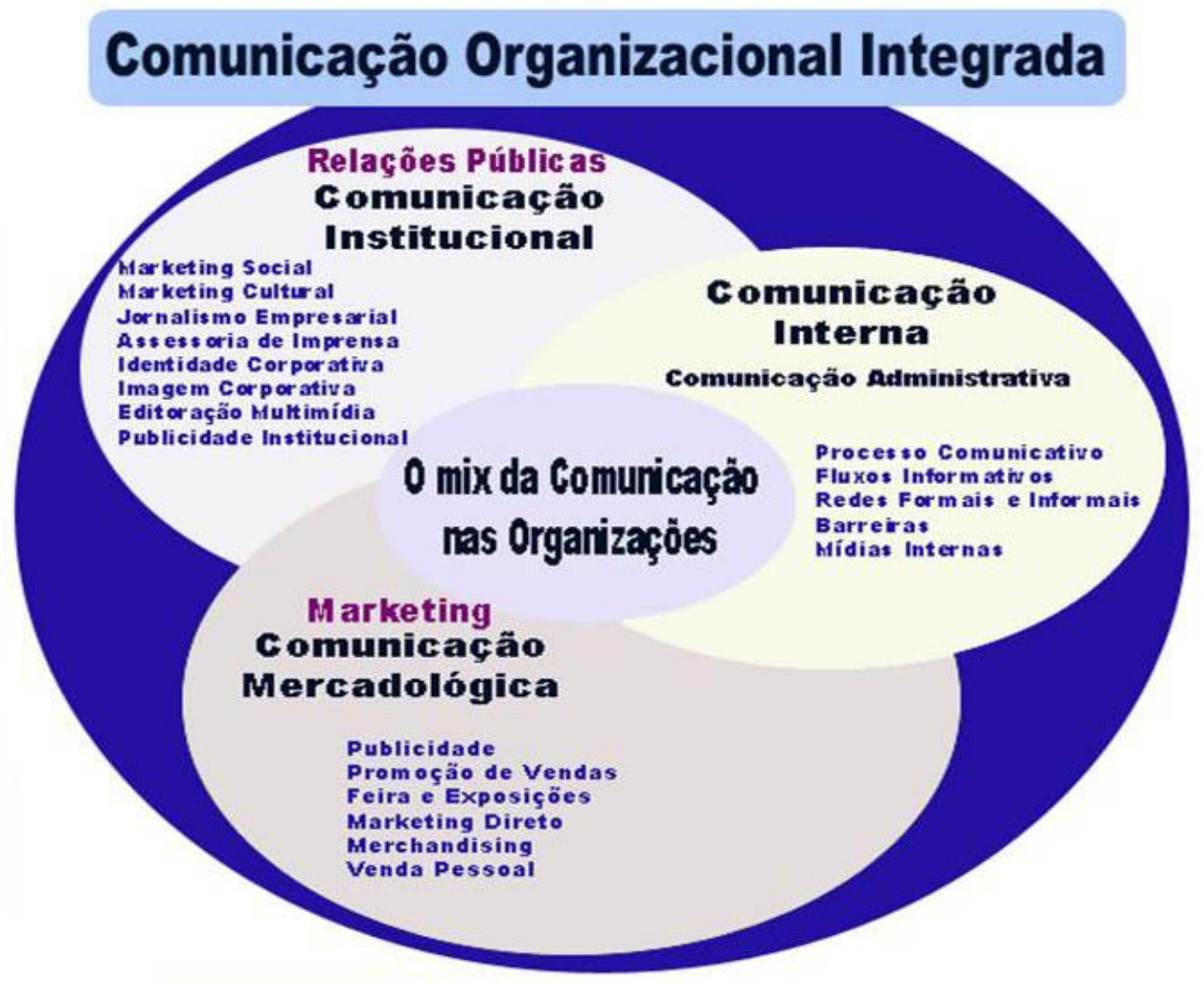

Fonte: KUNSCH, 2003, p. 178.

A seguir serão apresentadas as características das áreas desse composto da comunicação organizacional integrada: comunicação administrativa, comunicação interna, comunicação mercadológica e comunicação institucional. 


\subsubsection{Comunicação administrativa}

A comunicação administrativa é aquela que se processa dentro da organização e que permite organizar o fluxo de informações. Relaciona-se com "os fluxos, os níveis e as redes formal e informal de comunicação que permitem o funcionamento do sistema organizacional" (KUNSCH, 2003, p. 153). Pressupõe, portanto, um contínuo processo para que a organização possa planejar, administrar e gerenciar os seus recursos, visando ao alcance de seus objetivos.

A comunicação administrativa abrange todos os conteúdos do cotidiano da administração da organização, buscando atender às áreas centrais de planejamento e às estruturas técnico-normativas (TORQUATO DO REGO, 2002).

Segundo Charles Redfield (1980), a comunicação administrativa é composta por cinco elementos: (1) um comunicador, que (2) transmite (3) mensagens a um (4) destinatário visando a influenciar o comportamento deste, conforme comprovará a sua (5) resposta. Em tal processo, segundo Torquato do Rego (2002), falhas e distorções são comuns, devido ao desconhecimento do sistema, à profusão dos centros emissores de comunicação e à carência de profissionais qualificados para tratar e administrar os elos da cadeia. Nesse sentido, Lupetti (2009) afirma que é preciso haver um gestor da comunicação administrativa, com amplo conhecimento sobre o sistema organizacional e o sistema de comunicação, para orientar e administrar os diferentes setores, gerando unificação, clareza e objetividade na construção das mensagens.

Embora a comunicação administrativa esteja diretamente relacionada ao funcionamento da organização, não deve ser confundida com a comunicação interna, a qual será apresentada a seguir.

\subsubsection{Comunicação interna}

A comunicação interna é aquela responsável pela interação entre a organização e seus empregados. Desenvolve-se paralelamente à comunicação administrativa, compondo 
com as outras áreas do processo comunicacional a integração da comunicação no âmbito organizacional (KUNSCH, 2003).

Kunsch (2003, p. 159-160) reforça o caráter estratégico da comunicação interna.

A importância da comunicação interna reside, sobretudo, nas possibilidades que ela oferece de estímulo ao diálogo e à troca de informações entre a gestão executiva e a base operacional, na busca da qualidade total dos produtos ou serviços e do cumprimento da missão de qualquer organização.

Assim, o investimento em comunicação interna traz, como retorno, maior participação e mobilização dos funcionários, pois o "público interno é um público multiplicador" (KUNSCH, 2003, p. 159).

Nessa mesma direção, Torquato do Rego (2002) afirma que a comunicação interna busca contribuir para o desenvolvimento e a manutenção de um clima positivo, propício ao cumprimento das metas estratégicas da organização, ao crescimento continuado de suas atividades e serviços e à expansão de suas linhas de produtos.

A comunicação interna, dessa forma, estimula o diálogo, a troca de informações entre os diferentes níveis hierárquicos, a manifestação de ideias e o sentimento de integração ao trabalho. Entretanto, para que a comunicação alcance os seus objetivos, devem ser observados alguns aspectos, relacionados com "políticas, estratégias, qualidade, conteúdo e linguagem, pessoal e uso de novas mídias com adequação das inovações tecnológicas" (KUNSCH, 2003, p. 160).

Lupetti (2009) destaca que a comunicação interna é voltada a todos os colaboradores e tem como finalidade propiciar a integração entre eles, compatibilizando os interesses dos funcionários aos da organização.

\subsubsection{Comunicação mercadológica}

Na sequência do composto da comunicação organizacional integrada, a comunicação mercadológica é apontada por Kunsch (2003) como aquela responsável pela produção 
comunicativa relacionada aos objetivos mercadológicos, objetivando a divulgação publicitária dos produtos ou serviços da organização.

A comunicação mercadológica está diretamente relacionada à área de marketing, responsável por estabelecer "os parâmetros e fornecer os subsídios necessários para toda a criação e organização da comunicação mercadológica" (KUNSCH, 2003, p. 162). Lupetti (2009) ressalta que a comunicação mercadológica envolve qualquer forma de comunicação capaz de atingir um objetivo de marketing.

Torquato do Rego (2002, p. 168) relaciona o conceito de marketing ao contexto do processo comunicacional, ao afirmar que marketing é um conjunto de atividades voltadas a “promover relações de trocas entre um emissor e um receptor, no momento certo, por meio de canais adequados e mensagens apropriadas que atinjam o foco de interesses dos segmentosalvo".

Na mesma linha, Pinho (2006, p.40) define a comunicação mercadológica como “aquela projetada para ser persuasiva, para conseguir um efeito calculado nas atitudes e/ou comportamento do público visado”. O autor acrescenta que esse tipo de comunicação é desenvolvido pelas relações públicas e pela publicidade e propaganda.

Para Kotler e Keller (2006, p. 533), a comunicação de marketing permite às empresas "conectar suas marcas a outras pessoas, lugares, eventos, marcas, experiências, sensações e objetos”.

\subsubsection{Comunicação institucional}

A comunicação institucional é aquela responsável pela construção e pelo fortalecimento da identidade corporativa, por meio da gestão estratégica das relações públicas. Ressalta aspectos relacionados com “a missão, a visão, os valores e a filosofia da organização e contribuindo para o desenvolvimento do subsistema institucional, compreendido pela junção desses atributos" (KUNSCH, 2003, p. 164-165). 
A missão, a visão e os valores da organização compõem a identidade corporativa. $\mathrm{Na}$ concepção de Kunsch (2003, p. 241), a missão "é o conceito da organização em si, sua razão de ser, de existir". Ianhez (2006, p. 102) complementa: “é a expressão de um compromisso compartilhado". Já a visão, representa o posicionamento futuro que a organização quer assumir, ou seja, como quer ser vista pelos públicos a ela vinculados (KUNSCH, 2003); é "um guia para se determinar o nível de ambição da organização e uma seta indicativa para qualquer planejamento" (IANHEZ, 2006, p. 104). Por fim, os valores "traduzem as convicções filosóficas dos principais dirigentes e os atributos que acreditam que a organização deva ter como princípio para direcionar suas atividades"; são um "conjunto de traços culturais, institucionais e de atitudes definidos de maneira sistemática ou em sua coerência interna na busca do alcance dos objetivos da empresa” (YANAZE, 2011, p. 458).

Para Torquato do Rego (1985, p. 183), a comunicação institucional tem o objetivo de “conquistar simpatia, credibilidade e confiança, realizando, como meta finalista, a influência político-social"'.

A comunicação institucional é formada por "subáreas ou instrumentos que convergem para formatar uma comunicação da organização em si, como sujeito institucional, perante seus públicos, a opinião pública e a sociedade em geral” (KUNSCH, 2003, p. 166).

Esses instrumentos, segundo a autora, são: as relações públicas (a quem cabe gerenciar a comunicação institucional), o jornalismo empresarial, a assessoria de imprensa, a publicidade/propaganda institucional, a imagem e a identidade corporativa, o marketing social, o marketing cultural e a editoração multimídia.

Conforme exposto, a comunicação organizacional integrada compreende um processo global de comunicação, com o propósito de "nortear e orientar toda a comunicação que é gerada na organização, como um fator estratégico para o desenvolvimento organizacional na sociedade" (KUNSCH, 2003, p. 179). 
Kunsch (2003, p. 180) ressalta que a importância da comunicação integrada tem seu princípio no fato de "permitir que se estabeleça uma política global, em função de uma coerência maior entre os diversos programas comunicacionais, de uma linguagem comum a todos os setores e de um comportamento organizacional homogêneo". Além disso, segundo a autora, evita a sobreposições de tarefas.

Por meio de um sistema integrado, os vários setores de comunicação de uma organização podem coordenar esforços, visando alcançar os objetivos gerais, respeitando os objetivos específicos de cada setor (KUNSCH, 2003; LUPETTI, 2009).

Dessa forma, evidencia-se a necessidade de as organizações conceberem e executarem planos, projetos e programas de forma articulada - atentando para a comunicação institucional, administrativa e mercadológica -, uma vez que as estratégias comunicacionais envolvem todos os integrantes e setores da organização. Assim, a administração dessa integração depende do planejamento das ações, o qual será objeto de análise na próxima seção.

\subsection{Planejamento}

O planejamento envolve a seleção de objetivos e diretrizes, programas e procedimentos a serem desenvolvidos, tanto para a organização como um todo, quanto para cada departamento (KOONTZ; O’DONNELL, 1973). Nessa mesma linha, Megginson et al. (1998) definem o planejamento como o processo de estabelecer objetivos ou metas, determinando a melhor maneira de atingi-las.

Albuquerque (1981, p. 13) entende o planejamento como um "conjunto de estudos, pesquisas, levantamentos, projetos, programas, que visam possibilitar uma intervenção sobre a realidade que se quer modificar". Já para Ackoff (1978), o planejamento busca tanto evitar ações incorretas, quanto reduzir a frequência dos fracassos, ao se explorar as oportunidades. 
O planejamento pode ser considerado, portanto, como um processo desenvolvido para o alcance de uma situação desejada de um modo mais eficiente, eficaz e efetivo, com a melhor concentração de esforços e recursos (OLIVEIRA, D., 2003).

Faz-se necessário esclarecer a diferença entre eficiência, eficácia e efetividade.

\begin{abstract}
Eficiência significa fazer bem-feito, de maneira adequada, com redução de custos, desempenho competente e rendimento técnico. Eficácia liga-se a resultados - em função dos quais é preciso escolher alternativas e ações corretas, usando para tanto conhecimento e criatividade para fazer o que é mais viável e certo. Efetividade relaciona-se com a permanência no ambiente e a perenidade no tempo, no contexto da obtenção dos objetivos globais (KUNSCH, 2003, p. 205).
\end{abstract}

O processo de planejamento interfere na realidade para transformá-la e construí-la com as características que se deseja, por meio de planos, programas e projetos (GANDIN, 2000). É também um processo político, pois depende de decisão política dos grupos envolvidos e da articulação desses grupos (BAPTISTA, 2000).

Kunsch (2003, p. 207) adverte que o planejamento vai além de um processo mecânico, de saber o que fazer, de que modo e com que recursos. Trata-se de um processo complexo e abrangente, que exige "conhecimentos, criatividade, análises conjunturais e ambientais, além de aplicativos instrumentais técnicos".

De forma sintética, baseado em Dias (1982), é possível apontar as principais vantagens da utilização do planejamento nas organizações: a) possibilita a coordenação de esforços e a maximização dos recursos; b) faz com que a organização perceba a sua própria razão de existir; c) permite aferir se está perseguindo os objetivos propostos; d) aumenta o nível de interação entre as pessoas da organização; e) amplia as perspectivas dos dirigentes, que assim podem encontrar novas ideias sobre oportunidades a serem exploradas.

O planejamento pode ser dividido em três tipos: planejamento estratégico, planejamento tático e planejamento operacional (OLIVEIRA, D., 2003).

O planejamento estratégico é a mais importante etapa que uma organização pode desenvolver (TAVARES, 2010), na medida em que cria as condições para que a organização 
decida de forma rápida diante de oportunidades e riscos (MOREIRA, PASQUALE; DUNER, 2003). Ocupa o topo da pirâmide da organização, caracteriza-se como de longo prazo e está presente em toda a organização (OLIVEIRA, D., 2003). Pode ser visto como uma técnica administrativa que, por meio da análise do ambiente, identifica os pontos fortes e fracos para o cumprimento da missão organizacional e, dessa forma, “estabelece o propósito de direção que a organização deverá seguir para aproveitar as oportunidades e evitar riscos" (FISCHMAN; ALMEIDA, 1991, p. 25).

Conforme Kunsch (2009, p. 111), a concepção de planejamento estratégico está associada à administração estratégica e ao pensamento estratégico.

\begin{abstract}
A administração estratégica alia o planejamento estratégico com a tomada de decisão operacional em todos os níveis. Implica a mudança de atitudes na cúpula, nas condutas externas e nos participantes do processo. Desenvolve o espírito crítico nas pessoas, visando a novas soluções estratégicas, administrativas ou operacionais, voltadas para melhor adaptação ao ambiente, e objetivando uma postura empreendedora.
\end{abstract}

Vale frisar que, no que diz respeito ao planejamento estratégico, a natureza da organização precisa ser considerada. Em organizações públicas, há a busca pela valorização social dos bens e serviços produzidos pela instituição; já em organizações privadas, o foco é a conquista de vantagens competitivas (CASTRO; LIMA; BORGES-ANDRADE, 2005).

O planejamento tático é criado em níveis organizacionais inferiores com a finalidade de usar recursos disponíveis para alcançar os objetivos esperados (OLIVEIRA, D., 2003). Caracteriza-se por um impacto de médio prazo e abrange determinados setores da organização, normalmente acontece no nível gerencial, com a finalidade de decidir e operacionalizar as grandes decisões estratégicas tomadas pela alta administração (FERNANDES; BERTON, 2005). Busca atender a demandas imediatas, por meio de ações administrativas (KUNSCH, 2003).

Já o planejamento operacional é um plano de curta duração, com o objetivo de controlar as rotinas de uma unidade da organização (TAVARES, 2010), por meio de 
documentos escritos, metodologias e implantação (OLIVEIRA, D., 2003). As decisões operacionais ocorrem no cotidiano das organizações, estabelecendo uma ligação entre decisões táticas e estratégicas e seu impacto se dá no curto prazo, afetando apenas determinados setores ou áreas específicas da organização (FERNANDES; BERTON, 2005). De modo que essa forma de planejamento controla a execução e busca corrigir os desvios quanto às ações propostas (KUNSCH, 2003).

O Quadro 1 apresenta as diferenças entre esses três níveis de planejamento.

Quadro 1 - Diferenças entre os níveis de planejamento

\begin{tabular}{|l|l|l|l|}
\hline & Estratégico & Tático & Operacional \\
\hline Prazo & Longo prazo & Médio prazo & Curto prazo \\
\hline Amplitude & Todo & Parcial & Local \\
\hline Atividades & Maiores & $\begin{array}{l}\text { Menores do que o estratégico e } \\
\text { maiores do que } \\
\text { o operacional. }\end{array}$ & Menores \\
\hline Flexibilidade & Menor & Meios & Meios \\
\hline
\end{tabular}

Fonte: OLIVEIRA, D. (2003, p. 48).

Esses três tipos de planejamento coexistem; podem até ser examinados de forma separada, mas, na prática, ocorrem conjuntamente e são inseparáveis (ACKOFF, 1978).

A seguir serão analisados e aplicados os conceitos sobre planejamento no contexto da comunicação organizacional, para, então, dar início ao estudo da comunicação nas IES públicas, mais especificamente na UnB.

\subsubsection{Planejamento estratégico aplicado à comunicação organizacional}

Independentemente da filosofia de comunicação adotada por uma organização, o planejamento revela-se fundamental para o enfrentamento dos desafios, bem como para o aproveitamento de oportunidades de comunicação (ALBUQUERQUE, 1981). 
Vasconcelos (2009, p. 15) afirma que a busca por resultados pressupõe "a superação de obstáculos e a escolha da melhor estratégia para alcançá-los”. Portanto, planejar a comunicação é buscar a solução de problemas, a partir da compreensão das dificuldades e dos desafios em dado contexto (VASCONCELOS, 2009).

Na mesma linha, Kunsch (2003) aponta a necessidade de a organização moderna planejar, administrar e pensar estrategicamente a sua comunicação, para, assim, enfrentar os inúmeros desafios da complexidade contemporânea.

Não basta pautar-se por ações isoladas de comunicação, centradas no planejamento tático, para resolver questões, gerenciar crises e gerir veículos comunicacionais, sem uma conexão com a análise ambiental e as necessidades do público, de forma permanente e estrategicamente pensada (KUNSCH, 2003, p. 245).

Cardoso (2006) também aponta a necessidade de se compreender a estratégia organizacional como um processo de emergência estratégica.

Não é mais possível conceber e executar planos, projetos e programas isolados de comunicação institucional, mercadológica, de administração interna ou externa, pois uma estratégia comunicacional integra todos os setores da organização e envolve todos os seus participantes (CARDOSO, 2006, p. 1.140).

Por meio da constante atenção aos ambientes interno e externo, o planejamento estratégico orienta as decisões sobre a missão, os objetivos, as metas e as estratégias da organização (ARAÚJO, 1996). Portanto, os profissionais da área precisam atentar para as oportunidades e os riscos do macroambiente (TORQUATO DO REGO, 2015).

Vasconcellos Filho e Fernandes (1982) apresentam diversas vantagens do planejamento estratégico: possibilita o comportamento sinérgico das áreas funcionais da organização e a integração com o ambiente; torna a organização proativa; orienta o processo decisório; estimula a descentralização do processo de planejamento; favorece a adequação de modelos organizacionais aos diversos contextos ambientais e orienta o desenvolvimento dos planejamentos tático e operacional. 
Torquato do Rego (2015) apresenta algumas estratégias para a comunicação no âmbito das organizações, entre as quais: planejar a comunicação de maneira sinérgica e integrada, envolvendo os recursos comunicativos e as comunicações grupais e interpessoais; abrir e tornar mais equilibrados os fluxos de comunicação; valorizar e enfatizar canais participativos de comunicação; estabelecer uma identidade transparente e forte para projeção externa; criar uma linguagem sistêmica e uniforme, estabelecendo condições para uso e desenvolvimentos dos canais de comunicação; valorizar o pensamento criativo e acreditar na comunicação como um poder organizacional, identificando-a como investimento, não como despesa.

No sentido de viabilizar o planejamento estratégico de comunicação no âmbito das organizações, Kunsch (2003) propõe os seguintes princípios: a) cultura de planejamento do pensamento estratégico - o planejamento estratégico deve ser percebido como um instrumento capaz de direcionar as atividades da organização, visando alcançar os resultados pretendidos. Isso implica que a organização precisa estar atenta para criar e manter uma cultura de valorização do planejamento estratégico; b) área de comunicação subordinada à cúpula diretiva e participante da gestão estratégica - a área de comunicação precisa ter sua importância reconhecida e ocupar espaço estratégico na estrutura organizacional, sendo subordinada à alta direção e participando efetivamente da gestão estratégica; c) capacitação profissional - o responsável pela comunicação e da equipe precisa ter a capacitação adequada para pensar a comunicação organizacional de forma estratégica; d) valorização de uma cultura organizacional corporativa - a organização moderna precisa estimular o envolvimento das pessoas no processo de formulação do planejamento estratégico, dando-lhes oportunidade de equacionar as causas dos pontos fracos e fortes da comunicação organizacional integrada.

O planejamento estratégico em comunicação depende, portanto, de que esses quatro princípios sejam colocados em prática no âmbito da organização. 
Para Duarte e Monteiro (2009), a gestão da comunicação organizacional deve ser assumida por todos os seus membros, e não apenas pela cúpula diretiva da organização. Para esses autores, a comunicação organizacional precisa ser estimulada de forma permanente por seus agentes.

\begin{abstract}
Para um gestor de comunicação, o primeiro passo talvez seja transformar a comunicação de uma arte, de um empirismo, de ações pontuais, em uma prática institucionalizada, assegurada organicamente, garantindo o fornecimento, avalizado, de orientações, referências e oportunidades para qualificação de todas as ações de comunicação, em todos os níveis, ambientes e direções (DUARTE; MONTEIRO, 2009, p. 349).
\end{abstract}

Duarte e Monteiro (2009, p. 342) defendem a criação de uma consciência comunicativa, uma cultura organizacional que estimule a transparência, a confiança e a cooperação. Dessa forma, os autores propõem cinco pilares: 1) a informação compartilhada e integrada, respeitando as diferenças de atribuições, interesses e capacidades, criando uma rede de envolvidos; 2) pertencimento, sentimento de estar ligado a uma instituição; 3) empoderamento, formação de pessoas para o desenvolvimento de capacidades de intervenção crítica na realidade; 4) autonomia, estímulo à liberdade de pensamento e ação, com responsabilidade, compromisso e autocrítica; e 5) governança, reconhecendo que a responsabilidade quanto à comunicação organizacional é tarefa de todos e para todos.

Os autores ressaltam o papel do gestor de comunicação de incluir na agenda das organizações a pauta da comunicação, tornando-a uma atividade cotidiana: "o princípio geral é que todos os integrantes da organização devem ter estimulado seu interesse em ampliar a habilidade comunicativa" (DUARTE; MONTEIRO, 2009, p. 356).

Nessa mesma linha, Genelot (2001) aponta que a estratégia de comunicação organizacional agrega valores, possibilita a integração de grupos e pessoas e produz mediações significativas das organizações com seus diferentes públicos.

Genelot (2001) reforça a importância do desenvolvimento de uma consciência estratégica, em que toda a organização divide a visão de futuro. Mas adverte que tal visão não 
deve ser imposta pela cúpula, uma vez que se trata de um processo complexo, o qual envolve negociação e apropriação de valores mútuos. Assim, é preciso criar canais efetivos para que todos os participantes possam compartilhar ideias, atitudes e a cultura organizacional. Dessa forma, a comunicação organizacional pode se tornar, de fato, uma ferramenta estratégica (GENELOT, 2001).

Em suas análises e recomendações, os teóricos aqui citados não fazem diferenciação entre organizações públicas ou empresas privadas. Na próxima seção será analisada a organização universitária, a qual possui modelo de administração distinto das empresas privadas. Tal compreensão é importante para a análise da gestão da comunicação no contexto das IES públicas, particularmente da UnB.

\subsection{Organização Universitária}

Inicialmente, faz-se necessário conceituar e compreender as características da universidade. De forma sintética, Wanderley (1985) define universidade como uma instituição social que forma os profissionais, técnicos e intelectuais de que as sociedades necessitam. Segundo o autor, as universidades situam-se "na esfera da superestrutura, dentro da sociedade civil, mantendo vínculos com a sociedade política e a base econômica" (WANDERLEY, 1985, p. 11).

Blau e Scott (1979) definem a universidade como uma organização formal, uma vez que é estabelecida de modo convencional, possui uma estrutura interna e está organizada para atingir seus objetivos primordiais de ensino, pesquisa e extensão. Mas, apesar de ser uma organização formal, a universidade diferencia-se das demais organizações, "sobretudo pelas suas finalidades, seu tipo de atividades, suas formas de controle e funções que desempenha na sociedade". E a maneira como a universidade é controlada depende essencialmente das formas de propriedade, se é publica ou privada (PERROW, 1972). 
A partir do levantamento das tipologias organizacionais, é possível categorizar e compreender melhor o modelo das universidades. Neste estudo, são adotadas as ideias dos autores Etizioni (1974), Katz e Kahn (1978) e Blau e Scott (1979), que incluem as organizações universitárias em seus esquemas tipológicos.

Etizioni (1974) desenvolve o conceito de consentimento, descrevendo-o como uma relação baseada no poder coercivo, remuneratório e normativo dos superiores para controlar os subordinados e a percepção destes em relação a esse poder. A tipologia desse autor identifica três grupos principais: Organizações Coercivas, em que o exercício do poder se dá, principalmente, por meio de sanções físicas. Exemplos de organizações desse grupo são as instituições penais; e Organizações Utilitárias, as quais utilizam o poder remuneratório e participação calculista, o que resulta em um consentimento utilitário. Alguns exemplos são os bancos, os órgãos governamentais e as fábricas; Organizações Normativas, em que predomina o consentimento normativo, baseado na internalização das diretrizes e normas aceitas como legítimas. É nessa categoria em que se enquadram as universidades.

Para Katz e Kahn (1978), as organizações podem ser enquadradas em quatro tipos, a partir da atividade em que se achem empenhadas: Organizações Produtivas ou Econômicas, dedicadas à criação de riqueza, manufatura de bens e prestação de serviços. São organizações que geram produtos e serviços, tais como as indústrias; Organizações de Manutenção, dedicadas à socialização. A escola e a igreja são exemplos; Organizações Adaptativas, voltadas à criação, desenvolvimento e transmissão de conhecimentos. As universidades enquadram-se nessa categoria; e Organizações Políticas e Administrativas, dedicadas ao controle de recursos, pessoas e subsistemas. Exemplos desse tipo são as entidades governamentais e os sindicatos.

Blau e Scott (1979) propõem uma classificação baseada nos principais beneficiários. A partir desse critério, os autores identificam quatro tipos de organização: Associação de 
Benefícios Mútuos, em que o beneficiário principal é o quadro social, a exemplo dos clubes sociais, sindicatos e consórcios; Firmas Comerciais, no qual o beneficiário principal é o proprietário, como as empresas privadas em geral e as Organizações de Serviços, nas quais os principais beneficiários são clientes ou usuários. As universidades são consideradas um exemplo desse tipo de organização; e Organizações de Bem-Estar Público, nas quais o beneficiário principal é toda a comunidade. Ilustram esse tipo a organização militar e os Correios.

Quadro 2 - Tipologia organizacional e a universidade

\begin{tabular}{|l|l|l|l|}
\hline & TIPO & FUNÇÃO & AUTOR(ES) \\
\cline { 2 - 4 } & $\begin{array}{l}\text { Organização } \\
\text { Normativa }\end{array}$ & $\begin{array}{l}\text { Ajuda a manter os valores e as } \\
\text { normas aceitas pela sociedade. }\end{array}$ & ETIZIONI, 1974. \\
\cline { 2 - 4 } UNIVERSIDADE & $\begin{array}{l}\text { Organização de } \\
\text { Manutenção e } \\
\text { Adaptação }\end{array}$ & $\begin{array}{l}\text { Gera conhecimentos, } \\
\text { desenvolve e testa teorias, além } \\
\text { de aplicar os dados disponíveis } \\
\text { para resolver questões existentes } \\
\text { na sociedade. }\end{array}$ & KATZ e KAHN, 1978. \\
\cline { 2 - 4 } & $\begin{array}{l}\text { Organização de } \\
\text { Serviços }\end{array}$ & $\begin{array}{l}\text { Sua função básica é prestar } \\
\text { serviços aos “usuários”. }\end{array}$ & BLAU e SCOTT, 1979. \\
\hline
\end{tabular}

Fonte: Elaboração do autor.

A literatura sobre a estrutura das universidades, em especial das Instituições de Ensino Superior (IES) públicas, aponta que esta é complexa e multifuncional.

Segundo Baldridge e Deal (1983), as universidades caracterizam-se por possuir: a) objetivos ambíguos e difusos, pois o trabalho realizado pelas universidades não tem um foco específico, o que dificulta o planejamento e a tomada de decisão; b) natureza política, uma vez que há muitos grupos com objetivos distintos no ambiente universitário e as decisões são negociadas; c) usuários com necessidades individualizadas e diversificadas, já que os grupos que utilizam os serviços das universidades possuem voz ativa no processo decisório; d) tecnologia complexa, pois as universidades precisam de métodos, processos e tecnologias diversificadas para atender às diferentes demandas; e) sensibilidade a fatores externos, porque 
as universidades precisam se manter atualizadas e adaptadas às mudanças, tendo em vista a rapidez com que determinados conhecimentos se tornam obsoletos.

A pesquisadora Elaine Oliveira (1994) identifica os seguintes elementos estruturantes da organização universitária: a) diversidade de fins - ensino, pesquisa e extensão; b) mensuração limitada, uma vez que os objetivos são aferidos de forma parcial; c) autonomia e dependência na relação com a sociedade, da qual depende economicamente, mas resguardada em função do prestígio; d) difusão da autoridade, com múltiplos centros de influência que escapam ao poder central; e) fragmentação interna, devido à elevada autonomia, "baseada no profissionalismo, na especificação, na tradição e na própria natureza das atividades" (OLIVEIRA, E., 1994, p. 20).

Desta forma, podemos perceber que a universidade é uma organização não só única, mas intrinsecamente complexa, movendo-se num ambiente altamente turbulento e dinâmico, influenciada por crescente democratização, complexidade social e progresso técnico e científico. É nesse ambiente turbulento e em constante mudança, no qual a universidade está inserida, que surge a necessidade dela mesma examinar não somente as condições ambientais, como também, e principalmente, aquelas de natureza interna de forma a direcionar, mais racionalmente, a organização para o amanhã (OLIVEIRA, E., 1994, p. 20).

Araújo (1996) reforça a ideia de que a universidade, pela sua estruturação, precisa ser vista de forma diferente da ótica racionalista de outras organizações. Segundo a pesquisadora, as características mais relevantes da organização universitária são as seguintes: elevado profissionalismo, pois as tarefas são preparadas por especialistas, que demandam autonomia no trabalho; decisões descentralizadas, o que leva a organização a crescer de forma desigual, ou seja, diferentes partes progridem de forma diversa, em circunstâncias específicas; coexistência de concepções distintas de universidade por parte das unidades que compõem a instituição.

Essa multiplicidade de concepções dificulta a definição da missão, dos objetivos e da meta da organização; poder ambíguo e disperso, pelo fato de haver concepções diferentes, o que leva os integrantes a buscarem prevalecer as suas orientações; reduzida coordenação das 
tarefas, pois as estruturas são articuladas de forma débil, com o envolvimento de muitos e diversos atores; metas ambíguas e vagas e tecnologias diferenciadas por lidar com públicos com necessidades variadas (ARAÚJO, 1996).

Camatti (2014) identifica nas universidades brasileiras um ambiente dinâmico, tendo em vista que a formação acadêmica tem como foco a atuação profissional, com estímulo à inovação; complexo, pela necessidade de equilibrar gestão e educação; diverso, por englobar conhecimentos diversos em áreas diferentes; e hostil, devido à concorrência do mercado estabelecida nos últimos anos no segmento do ensino superior.

Segundo Maiochi (1997, p. 244), a diferença fundamental entre a administração universitária e a administração de empresa está na missão específica: “a universidade é essencialmente diferente das empresas nos seus 'negócios'. É diferente na finalidade, possui valores diferentes, faz contribuição diferente à sociedade”.

A autora apresenta o seguinte quadro esquemático comparativo entre os modelos de administração universitária e empresarial: 
Quadro 3 - Universidade x empresa - características organizacionais

\begin{tabular}{|c|c|c|}
\hline CARACTERÍSTICAS & UNIVERSIDADE & EMPRESA \\
\hline OBJETIVOS & $\begin{array}{l}\text { - Difusos } \\
\text { - Prestação de serviços } \\
\text { (públicos) (não lucrativos) } \\
\text { - Pouco consensuais }\end{array}$ & $\begin{array}{l}\text { - Definidos } \\
\text { - Econômicos (lucros) } \\
\text { - Consensuais }\end{array}$ \\
\hline TECNOLOGIA & $\begin{array}{l}\text { - Múltipla, complexa e } \\
\text { indefinida }\end{array}$ & - Definida \\
\hline ESTRUTURA & $\begin{array}{l}\text { - Burocracia centralizada } \\
\text { (universidade de menor } \\
\text { porte) } \\
\text { - Burocracia descentralizada, } \\
\text { fragmentada (universidade de } \\
\text { maior porte) }\end{array}$ & $\begin{array}{l}\text { - Hierarquizada } \\
\text { - Claramente definida } \\
\text { - Poder e propriedade } \\
\text { - Estrutura centralizada e integrada (pequenas } \\
\text { empresas) } \\
\text { - Estrutura descentralizada (médias e grandes } \\
\text { empresas) }\end{array}$ \\
\hline PARTICIPANTES & $\begin{array}{l}\text { - Dirigentes } \\
\text { - Professores } \\
\text { - Funcionários } \\
\text { - Alunos }\end{array}$ & $\begin{array}{l}\text { - Acionistas } \\
\text { - Dirigentes } \\
\text { - Técnicos e trabalhadores }\end{array}$ \\
\hline CLIENTELA & $\begin{array}{l}\text { - Alunos } \\
\text { - Comunidade em geral } \\
\text { - Comunidade científica }\end{array}$ & - Clientela \\
\hline PRODUTO & - De difícil mensuração & - Qualificável \\
\hline ADMINISTRAÇÃO & $\begin{array}{l}\text { - Ausência de padrões de } \\
\text { performance } \\
\text { - Limitada utilização dos } \\
\text { princípios administrativos } \\
\text { - Utilização menos racional } \\
\text { dos recursos disponíveis } \\
\text { - Utilização de instrumentos } \\
\text { pouco sofisticados }\end{array}$ & $\begin{array}{l}\text { - Padrões de performance definidos } \\
\text { - Alta utilização dos princípios administrativos } \\
\text { - Utilização racional dos recursos disponíveis } \\
\text { - Compromissos com resultados } \\
\text { - Desempenho organizacional medido por } \\
\text { variáveis (instrumentos quantitativos de análise) } \\
\text { - Retorno sobre o investimento } \\
\text { - Custo/benefício }\end{array}$ \\
\hline PROCESSO DECISÓRIO & $\begin{array}{l}\text { - Racionalidade política } \\
\text { - Decisões baseadas no } \\
\text { interesse político/social } \\
\text { - Participação de diversos } \\
\text { grupos de interesse } \\
\text { - Unidades autônomas de } \\
\text { decisão }\end{array}$ & $\begin{array}{l}\text { - Racionalidade econômica } \\
\text { - Decisões baseadas em fatores econômicos e } \\
\text { quantitativos } \\
\text { - Sistema integrado de decisão }\end{array}$ \\
\hline AMBIENTE & $\begin{array}{l}\text { - Estável (relativamente) } \\
\text { - Menos vulnerável e fatores } \\
\text { ambientais }\end{array}$ & $\begin{array}{l}\text { - Competitivo } \\
\text { - Altamente vulnerável a fatores ambientais }\end{array}$ \\
\hline
\end{tabular}

Fonte: MAIOCHI (1997, p. 247). 
Kunsch (1992, p. 23) destaca o papel fundamental da universidade para a construção da sociedade moderna: "Ela tem um compromisso com o passado, preservando a memória; com o presente, gerando novos conhecimentos e formando novos profissionais; e com o futuro, funcionando como vanguarda".

Essas peculiaridades, que fazem a universidade uma estrutura complexa e diferente de outras organizações, precisam ser levadas em consideração no planejamento estratégico da instituição (ARAÚJO, 1996). A adequação desse instrumental à realidade das organizações universitárias será discutida na próxima seção deste estudo.

\subsection{Planejamento estratégico nas universidades}

As universidades são consideradas um tipo peculiar de organização e isso conforma os seus processos administrativos, inclusive no que se refere ao processo de planejamento (ARAÚJO, 1996). Cabe analisar se o planejamento realizado no âmbito da organização universitária pode assumir características de planejamento estratégico.

Araújo (1996) identifica as seguintes dificuldades para a efetivação do planejamento estratégico no âmbito da universidade: 1) falta de habilidade da instituição em realizar ajustes imediatos em função de oportunidades externas; 2) inexistência de um sistema de informações gerenciais eficiente e ágil, voltado para a identificação de ameaças e oportunidades; 3) ausência de clareza sobre a missão, os objetivos e as metas da organização. Falta uma visão compartilhada da organização universitária, o que dificulta ou invalida a discussão de metas e estratégias da organização; 4) falta de percepção da importância de se institucionalizar o planejamento no conjunto da universidade, pelo fato de o planejamento estar dissociado da gestão e pelo baixo envolvimento da comunidade acadêmica no planejamento. Além disso, as instâncias colegiadas não são estimuladas a pensar estrategicamente; e 5) indefinição de alocação de recursos, o que gera insegurança e instabilidade. 
Outros autores, como Cunha (1995) e Estrada (2000), apontam alguns entraves. Para o primeiro, falta estrutura de poder bem definida, conhecimento para a implantação e uma metodologia adequada; além disso, aponta a interferência de questões políticas. Já Estrada (2000) enumera várias dificuldades, entre as quais: 1) falta de conhecimento sobre planejamento estratégico; 2) falta de cultura de planejamento; 3) falta de vontade ou de poder político; 4) despreparo administrativo dos dirigentes; 5) falta de execução de todas as etapas do modelo adotado; 6) complexidade da estrutura universitária; 7) descompasso nos mandatos de reitor e diretores; 8) falta de quantificação e especificação das ações; e 9) falta de controle e avaliação das ações.

Especificamente no âmbito das universidades públicas, é possível apontar como uma das principais dificuldades para a adoção do planejamento estratégico a descontinuidade das ações de uma gestão para a outra, implicando comprometimento de recursos e investimentos aplicados (IPEA, 2005).

Costábile (2007) aponta a falta de conhecimentos suficientes por parte dos administradores das IES para entender os problemas da instituição, o que leva a decisões sem uma ordem de priorização a serem tomadas para a efetivação do planejamento estratégico.

Araújo (1996) ressalta que essas dificuldades não inviabilizam a adoção do planejamento estratégico nas universidades, mas sim, indicam que é necessário repensar o planejamento nessas instituições, de modo a criar as condições para a implantação desse instrumento gerencial.

Para Tousignant (1990, p. 23), o planejamento nas universidades é tanto mais possível quanto maior é o respeito pelas características da instituição universitária. "Muitos fracassos no planejamento são atribuídos à ignorância, ao esquecimento ou ao desprezo dessa configuração estrutural particular da universidade". 
Araújo (1996) aponta as seguintes premissas para o planejamento estratégico nas universidades: a universidade é uma estrutura social interna composta de grupos de interesse com diferentes metas e valores; o critério de avaliação de decisões é predominantemente político; as dimensões sociais e políticas na formulação do planejamento devem ser incorporadas e trabalhadas no nível dos atores envolvidos; pressões externas são conformadoras dos processos internos de gestão; a dimensão de participação deve ser incorporada no processo de planejamento; o planejamento participativo é, essencialmente, um processo de negociação entre fins e meios.

Dessa forma, é possível perceber o processo decisório em universidades como mais dependente do conflito e da ação política. "Isso significa que as decisões são, antes de tudo, compromissos negociados" (ARAÚJO, 1996, p. 82).

O planejamento estratégico universitário, conforme Estrada (2000), implica uma nova postura organizacional e requer dos gestores habilidade para lidar com aspectos subjetivos e intuitivos presentes na gestão universitária, visão e liderança.

Bodini (1998) avalia que é possível as universidades adotarem o planejamento estratégico, desde que os gestores levem em conta que se trata de um sistema complexo. Para esse autor, é preciso reconhecer que a "clientela" desse sistema é a sociedade, que anseia por uma administração eficiente. Essa demanda crescente da sociedade tem levado as IES públicas a otimizarem os recursos disponibilizados pelo governo.

Nessa perspectiva, o Ministério da Educação (MEC), por meio do Sistema Nacional de Avaliação da Educação Superior (SINAES), percebeu a necessidade de as IES incluírem o planejamento estratégico, sintetizado no Plano de Desenvolvimento Institucional (PDI).

O artigo 16 do Decreto n. ${ }^{\circ}$ 5.773, de 9 de maio de 2006 (BRASIL, 2006), relaciona os seguintes itens que devem constituir o PDI das universidades: a) missão, objetivos e metas da instituição, em sua área de atuação, bem como seu histórico de implantação e 
desenvolvimento; b) projeto pedagógico da instituição; c) cronograma de implantação e desenvolvimento da instituição e de cada um de seus cursos; d) organização didáticopedagógica da instituição; e) perfil do corpo docente; f) organização administrativa da instituição, identificando-se as formas de participação de professores e alunos nos órgãos colegiados responsáveis pela condução dos assuntos acadêmicos e os procedimentos de autoavaliação institucional e de atendimento de alunos; g) infraestrutura física; h) oferta de educação a distância.

O PDI constitui-se, portanto, em um documento institucional que representa a formalização do planejamento das universidades. Abrangendo um período de cinco anos, deve contemplar, além dos elementos supracitados, o cronograma e a metodologia de implantação dos objetivos, metas e ações da instituição. Deve apresentar, também, um quadro com a relação dos principais indicadores de desempenho, que possibilite comparar a situação atual e futura. Dessa forma, o PDI torna-se um instrumento legal para a aferição da qualidade da gestão universitária.

A seguir será analisado o perfil institucional da Universidade de Brasília, com um breve histórico da FUB e o planejamento estratégico na UnB, a partir da análise do Plano de Desenvolvimento Institucional (PDI/UnB) de 2014-2017 (UNIVERSIDADE DE BRASÍLIA, 2015b), para identificar as estratégias específicas para a área de comunicação da universidade.

\subsubsection{Planejamento estratégico na Universidade de Brasília}

Inaugurada em 21 de abril de 1962, a Universidade de Brasília foi idealizada para funcionar em moldes pioneiros, autônoma, pública e sustentável, combinando o rigor da ciência com a ousadia da arte (UNIVERSIDADE DE BRASÍLIA, 2015b).

Por meio da Lei n. ${ }^{\circ}$ 3.998, de 15 de dezembro de 1961 (BRASIL, 1961), instituiu-se a Fundação Universidade de Brasília (FUB), incumbida de criar e manter a UnB. O objetivo de seus idealizadores foi estabelecer uma universidade inovadora, que contribuísse para a 
promoção e o desenvolvimento do país e do Distrito Federal (UNIVERSIDADE DE BRASÍLIA, 2015b). Tal concepção está expressa no art. $3^{\circ}$ do Estatuto da Universidade de Brasília, em que são consideradas finalidades essenciais da UnB “o ensino, a pesquisa e a extensão, integrados na formação de cidadãos qualificados para o exercício profissional e empenhados na busca de soluções democráticas para os problemas nacionais" (UNIVERSIDADE DE BRASÍLIA, 2011).

A estrutura acadêmica da UnB baseou-se na integração de três modalidades de órgãos: Institutos Centrais, Faculdades e os Órgãos Complementares. Esse modelo atendia às pretensões iniciais. Entretanto, devido às pressões por demanda de ensino superior público, foi necessário intensificar os esforços para um processo de expansão, tanto no aspecto físico quanto em serviços de educação ofertados pela universidade (UNIVERSIDADE DE BRASÍLIA, 2011, p. 14).

Tendo em vista essa necessidade de expansão e superação dos novos desafios que se impõem, a atual gestão da UnB decidiu revisar o seu planejamento estratégico. No primeiro semestre de 2014, foi iniciado o processo de planejamento da Universidade de Brasília (UnB) 2014-2017. Nesse sentido, o Decanato de Planejamento e Orçamento (DPO) - responsável por gerir e monitorar o planejamento estratégico da universidade - realizou, em março de 2014, o primeiro encontro de planejamento estratégico, em conjunto com uma equipe de especialistas e com a participação de todos os integrantes da administração central da UnB (UNIVERSIDADE DE BRASÍLIA, 2015b).

No primeiro encontro, foram definidas a Missão e Visão de Futuro. A missão da UnB é "ser uma instituição inovadora, comprometida com a excelência acadêmica, científica e tecnológica formando cidadãos conscientes do seu papel transformador na sociedade, respeitadas a ética e a valorização de identidades e culturas com responsabilidade social”. Já a Visão de Futuro da universidade "é estar entre as melhores universidades do Brasil, inserida 
internacionalmente, com excelência em gestão de processos que fortaleça o ensino, pesquisa e extensão" (UNIVERSIDADE DE BRASÍLIA, 2015b, p. 19).

Foi elaborada, também, a Matriz SWOT, técnica que identifica as correlações entre pontos fortes e oportunidades e ameaças, bem como entre pontos fracos e os mesmos elementos do ambiente externo. Essa técnica é utilizada nas organizações públicas e privadas para a construção do planejamento estratégico (UNIVERSIDADE DE BRASÍLIA, 2015b).

Com a finalização dos trabalhos da comissão de sistematização, o segundo encontro, realizado em julho de 2014, apresentou os resultados e decisão da Missão, Visão de Futuro e Matriz SWOT. A etapa seguinte consistiu na definição de Objetivos e Estratégias para a UnB combater as ameaças e pontos fracos e aproveitar seus pontos fortes e oportunidades. Com base nos resultados desses dois encontros, foi elaborado o Plano de Desenvolvimento Institucional (PDI) 2014-2017 da UnB (UNIVERSIDADE DE BRASÍLIA, 2015c).

Nesse documento, a comunicação da universidade é relacionada como um ponto fraco nos seguintes aspectos: "falta de integração em sistemas de informação e comunicação" e "fragilidade da comunicação interna e externa (comunitária, institucional e com a sociedade)"(UNIVERSIDADE DE BRASÍLIA, 2015b, p. 19).

Os cruzamentos realizados e a identificação dos elementos com maior relevância permitiram aos gestores identificar as áreas estratégicas de atuação da universidade, bem como traçar os objetivos e as estratégias necessárias para o alcance dos resultados (UNIVERSIDADE DE BRASÍLIA, 2015b, p. 23).

Na Figura 2 são apresentadas as quatro áreas estratégicas da UnB que provêm insumos à gestão e as três áreas responsáveis pela transformação das entradas em produtos finais à sociedade. 
Figura 2 - Matriz SWOT UnB 2014 - Análise preliminar de objetivos e estratégias

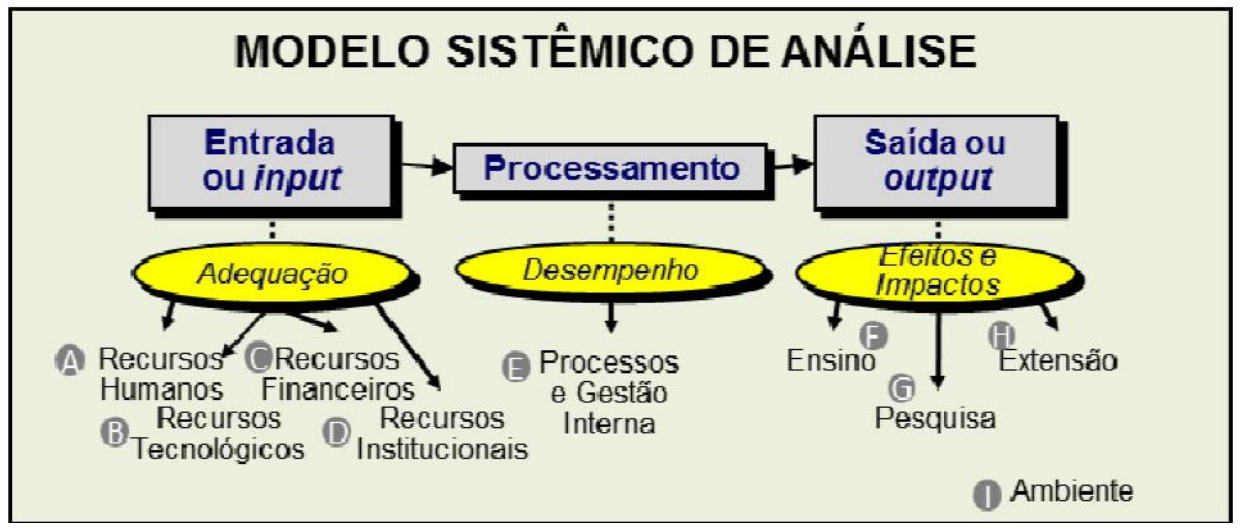

Fonte: UNIVERSIDADE DE BRASÍLIA, 2015b, p. 23.

Esse modelo sistêmico (Figura 2) serviu de base para a elaboração dos Objetivos e Estratégias da UnB. Na área de Recursos Tecnológicos, foi apontado como um dos objetivos o aprimoramento da comunicação institucional (interna e externa). Também foram definidas as seguintes estratégias específicas para a área de comunicação social: estabelecer política de comunicação e informação integradas - Secom, UnBTV e Rádio UnB; mapear e aprimorar as redes de comunicação, desenvolver sistemas que apoiem a comunicação; fortalecer as mídias da UnB (produção de conteúdos, organização, publicação e uso); implementar a UnBTV em sinal aberto e a Rádio UnB; implementar a intranet na UnB e padronizar o uso da identidade visual e marca UnB em todas as páginas na internet e documentos institucionais (UNIVERSIDADE DE BRASÍLIA, 2015b, p. 24).

Quanto à gestão, a UnB pretende para os próximos anos realizar e disseminar práticas que promovam a melhoria contínua dos processos estratégicos da instituição (UNIVERSIDADE DE BRASÍLIA, 2015b).

A percepção da universidade como uma organização social complexa, diferenciada, com diversas limitações e desafios a enfrentar para a adoção de um planejamento estratégico, é importante para o estudo da comunicação nesse processo, inclusive no âmbito da Universidade de Brasília. 
No próximo segmento será analisada a comunicação no contexto das IES públicas brasileiras, em uma perspectiva estratégica e integrada. Posteriormente, será apresentada a estrutura de comunicação social existente na UnB.

\subsection{Comunicação das universidades públicas brasileiras}

As universidades públicas, em tempos de prevalência de ideias que valorizam as atividades privadas, têm se preocupado em reconstruir a noção de público e conquistar a legitimidade no meio social (CASTRO, 2013).

A professora Maria Céres Spínola Castro (2013) destaca que, pelas suas características e finalidades (ensino, pesquisa e extensão), bem como sua relação intrínseca com o conhecimento e com a cultura, a universidade pública não deve se subordinar a expectativas de retorno de investimento.

(...) a universidade, como instituição pública, deve assumir a função de garantir o efetivo caráter público de que, em princípio, se revestem os bens de cultura e de ciência historicamente legados ao presente, na medida em que estes não se apresentem como produtos que as organizações comerciais possam vender no mercado (CASTRO, 2013, p. 2-3).

Nessa perspectiva, é preciso pensar a construção imagética da universidade pública não pela ótica do mercado, mas sim, levando em conta o empenho comunicativo de todos os integrantes dessa instituição pública (CASTRO, 2013).

\footnotetext{
É exatamente por se tratar de uma instituição polissêmica, que se caracteriza por uma necessária porosidade comunicativa, que a tarefa de produção da imagem não se restringe à área da comunicação institucional. Ela é responsabilidade e tarefa do conjunto dos membros da Instituição, apoiados e estimulados pelas estruturas que têm a seu cargo e competência a produção de instrumentos que viabilizem as ações comunicativas, seja no âmbito interno, seja na relação com o sistema de mídia ou, ainda, nas formas alternativas e inovadoras de interlocução com a sociedade externa à Universidade (CASTRO, 2013, p. 5-6).
}

Castro $(2013$, p. 7) aponta a necessidade de se planejar as estratégias de comunicação “mais adequadas ao perfil institucional, sua missão e seus públicos", a partir da "produção da visibilidade e facilitação do controle social". 
Para Castro (2013), a partir da exposição pública do serviço realizado e da interação com os diversos públicos é possível articular a universidade pública com o conceito de comunicação pública.

É nesse complexo de atuação - midiático, mas também interativo, de comunicação dirigida, com ampla participação da comunidade e com engajamento de uma comunicação interna, com o uso de recursos informacionais, virtuais, impressos, audiovisuais - que a comunicação serve à instituição e ao seu público, possibilitando que os diversos interesses que aí se manifestam possam assumir o caráter público, a dimensão societária e democrática a que a comunicação pública deve servir (CASTRO, 2013, p. 12).

Kunsch (1992) ressalta que a universidade precisa estar consciente da sua missão e não se isolar do mundo contemporâneo.

No mundo em que vivemos hoje, a universidade tem não só o dever, mas também a responsabilidade social de reproduzir sua pesquisa, de forma aberta, a toda a sociedade. Não se justifica mais uma produção científica enclausurada em arquivos e prateleiras, com restrito acesso de uma minoria privilegiada. É preciso democratizar a universidade. Um serviço de comunicação é o melhor caminho para a abertura de novos canais de diálogos e democracia, dentro e fora da universidade (KUNSCH, 1992, p. 27).

Segundo Kunsch (1992), não há mais espaço para a concepção de serviços parciais de comunicação nas universidades, sem planejamento integrado e sem políticas de comunicação bem definidas. Assim, a universidade necessita de um serviço de comunicação bem estruturado e planejado. Entretanto, segundo a autora, a comunicação no sistema organizacional universitário ainda se mostra incipiente, não sendo tratada como ferramenta estratégica.

Para Kunsch (2012, p. 110), a comunicação da universidade precisa ser vista numa perspectiva integrada e globalizante, de modo a se criar condições efetivas de interação entre as unidades e departamentos, bem como com o ambiente externo. "Para tanto, há que se planejar a comunicação em moldes tais que ela seja integrada da melhor maneira possível”. Além de evitar a duplicidade de esforços e a dispersão de recursos, a comunicação integrada permite incentivar trabalhos interdisciplinares e multidisciplinares, por meio de ações conjuntas (KUNSCH, 1992). 
No próximo tópico serão analisadas experiências em comunicação de Instituições de Ensino Superior (IES) públicas no contexto da comunicação organizacional integrada. Será apresentado o tratamento dispensado à área de comunicação social de universidades públicas com perfil semelhante à UnB. O estudo tem como fonte principal as informações disponíveis nos portais dessas instituições na internet.

\subsubsection{Panorama da comunicação em universidades públicas brasileiras}

Nos últimos dez anos, diversas universidade públicas brasileiras têm adotado uma estratégia de integração de diferentes órgãos, setores e meios de comunicação com o objetivo de obter mais eficiência e sinergia entre suas ações. A seguir serão apresentados alguns exemplos.

\subsubsection{O modelo da Universidade de São Paulo - USP}

A Universidade de São Paulo concentra na Superintendência de Comunicação Social (SCS/USP) todos os serviços desenvolvidos nesta área desde 1989. A SCS/USP é um órgão de direção diretamente subordinado à Reitoria da Universidade de São Paulo. A principal atribuição da SCS/USP é estabelecer as diretrizes de uma política global de comunicação da USP, além de coordenar os serviços ligados a essa área.

A superintendência concentra todos os meios e suportes de comunicação, organizando-os em divisões: Audiovisuais, Mídias Online, Mídias Impressas, Radiodifusão e Relações Públicas, Marketing e Publicidade. Dispõe, também, da Seção Técnica de Informática e da Assistência Técnica Administrativa e Financeira.

Segundo o site da SCS/USP, a Divisão de Mídias Audiovisuais responde pela TV USP: “produz e exibe programas, vídeos, documentários e especiais em Canais Universitários de diversas cidades do País, além de disponibilizar suas produções na internet, pelo site do IPTV (Internet Protocol Television)". A divisão serve, também, como "agregadora de 
conteúdos audiovisuais feitos por professores, alunos, funcionários, pesquisadores e outras pessoas ligadas à universidade ao garantir espaço para esses vídeos em sua programação" (UNIVERSIDADE DE SÃO PAULO, 2014).

A divisão de Radiodifusão é responsável pela gestão da rádio USP sob todos os aspectos de produção de conteúdo e técnico.

Figura 3 - Organograma da Superintendência de Comunicação Social da USP

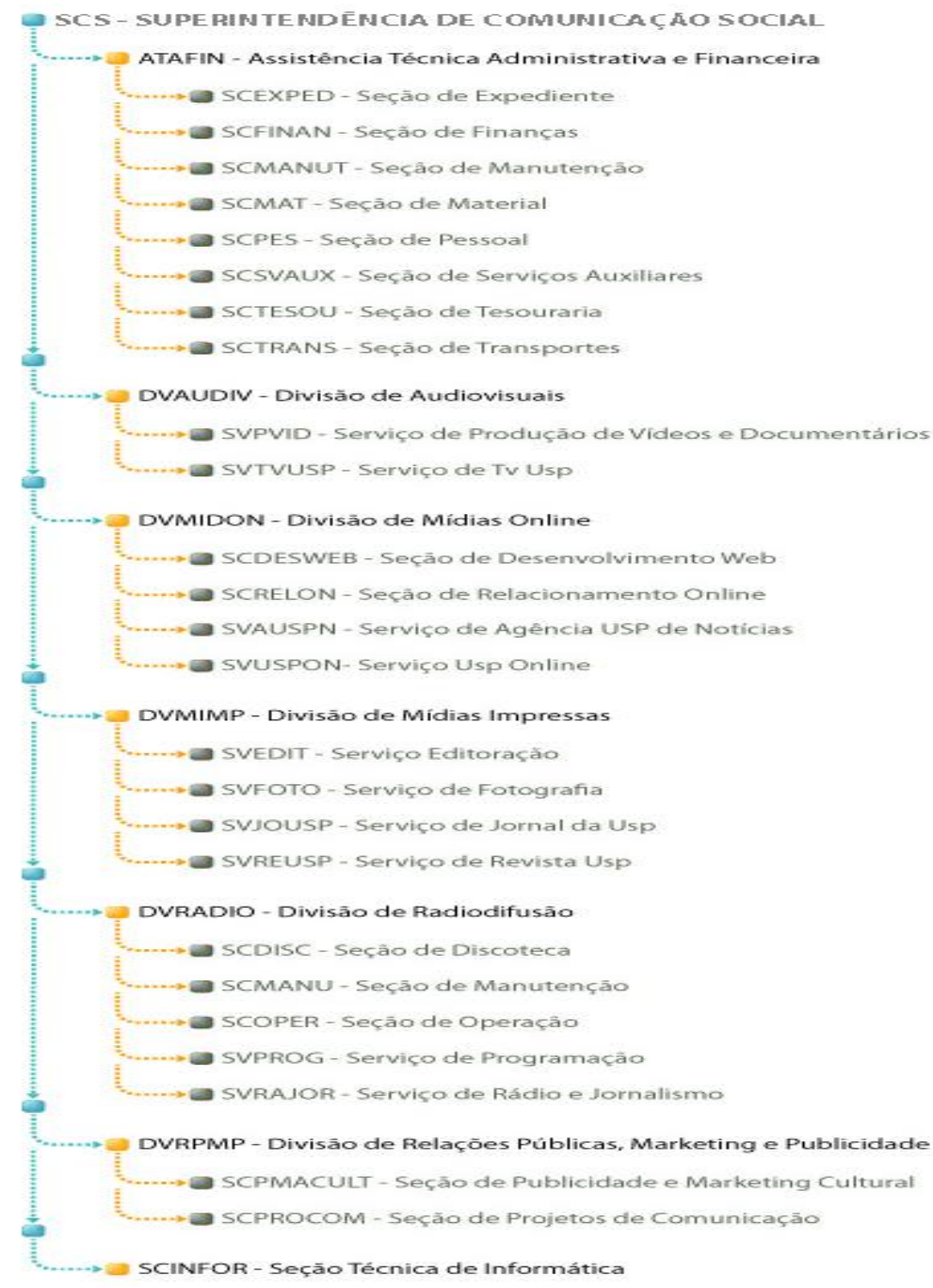

Fonte: UNIVERSIDADE DE SÃO PAULO, 2014.

Nota-se, pelo organograma, que não há uma divisão específica de Assessoria de Comunicação, mas sim, uma distribuição desse trabalho a partir de meios, suportes ou atividades: mídia online, impressa, rádio, $\mathrm{TV}$, relações públicas e marketing. $\mathrm{O}$ produto de 
maior relevância na SCS/USP é a Agência USP de Notícias, responsável por divulgar aos meios de comunicação a produção científica e atividades como cursos e palestras, exposições e publicações de todos os campi. Em funcionamento desde 1995, a agência produz boletins diários e os envia para mais de quatro mil endereços eletrônicos de todo o país. Esse número é multiplicado consideravelmente, pois conta, ainda, com a distribuição de boletins para os assinantes da Agência Estado (AE), por meio de um convênio celebrado entre as duas instituições (UNIVERSIDADE DE SÃO PAULO, 2014).

Embora seja um órgão de direção e serviço subordinado à Reitoria da USP, a SCS possui um setor próprio para fazer a gestão financeira, o que lhe garante maior agilidade na administração, especialmente dos veículos de rádio e a TV.

\subsubsection{O modelo da Universidade Federal Fluminense - UFF}

A exemplo da USP, a Universidade Federal Fluminense (UFF) organiza sua estrutura de comunicação na Superintendência de Comunicação Social (SCS). Trata-se de um órgão suplementar que concentra todos os serviços desenvolvidos na área.

Figura 4 - Organograma da Superintendência de Comunicação Social da UFF

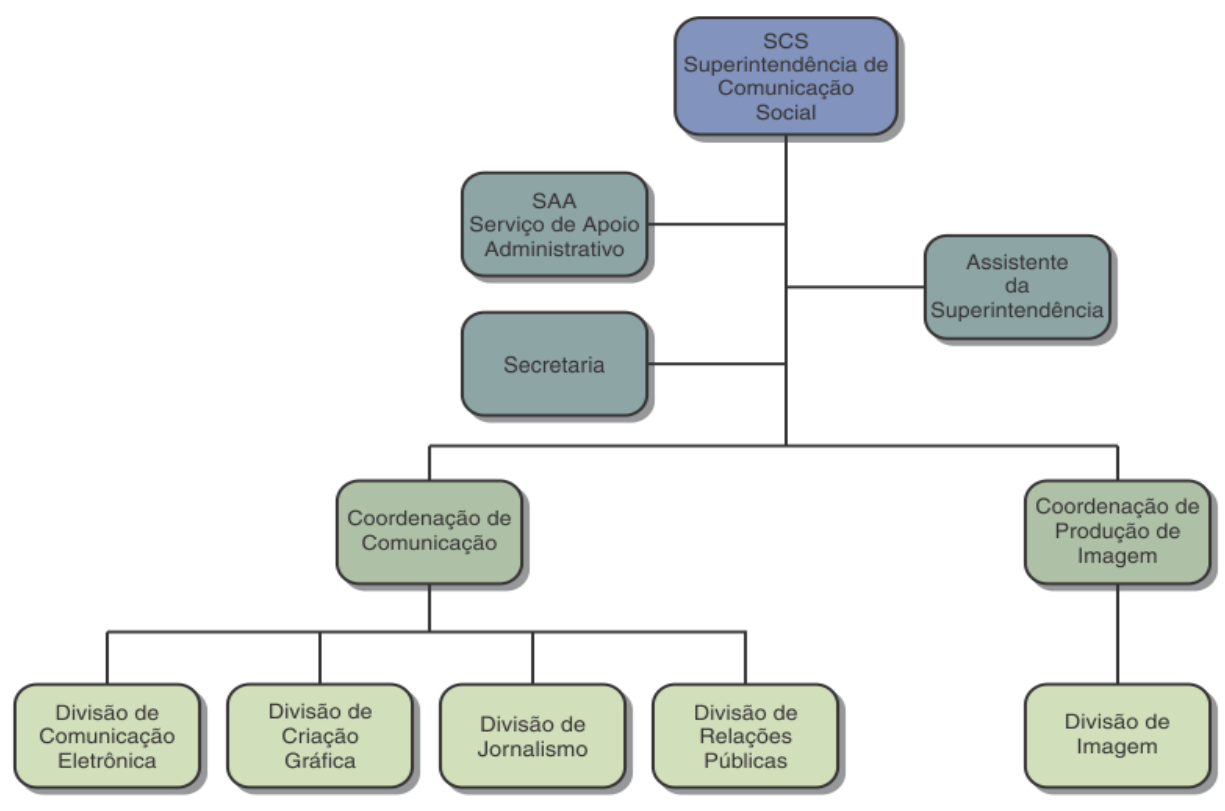

Fonte: UNIVERSIDADE FEDERAL FLUMINENSE, 2014. 
Segundo o site da UFF, a Superintendência de Comunicação Social atende a setores de toda a universidade que solicitam divulgação de suas atividades, interna e externamente, produção de material gráfico de apoio a eventos e campanhas institucionais, além de preparação e apresentação de solenidades (UNIVERSIDADE FEDERAL FLUMINENSE, 2014). Na superintendência, há três coordenadorias: a Unitevê - Canal Universitário de Niterói; a Coordenadoria de Comunicação Social e a Coordenadoria de Produção de Imagem. Essa divisão difere da feita pela USP por apenas identificar o serviço, desconsiderando o meio capaz de realizá-lo. Assim, aparentemente, no caso da UFF, não está claro como ocorre a atribuição de responsabilidade e competências sobre o trabalho de comunicação social a partir de diferentes mídias/meios, tais como a WebTV e a WebRádio.

A Unitevê é a UnBTV deles e conta com as divisões de Programação, Exibição e de Estúdio. Não há informações no site da UFF sobre que tipo de serviços compete a cada divisão da Unitevê.

Outro setor importante da Comunicação Social da UFF é a Coordenação de Comunicação, que está dividida em quatro áreas: Jornalismo, Comunicação Eletrônica, Relações Públicas e Criação Gráfica.

A Divisão de Jornalismo é responsável pela divulgação interna e externa dos projetos de ensino, pesquisa e extensão e das atividades complementares. O setor funciona como uma assessoria de comunicação, tendo sob sua responsabilidade o contato com jornalistas (por release, telefone e outros meios) e a produção do clipping eletrônico. O setor também produz o clipping impresso, à disposição do público em geral por meio do Mural Eletrônico no saguão de entrada da Reitoria. Edita, ainda, o Jornal da UFF, informativo destinado às comunidades interna e externa. 
A Divisão de Comunicação Eletrônica é responsável pela divulgação das notícias da UFF, produzidas pelo Setor de Jornalismo, e pela atualização diária da página principal daquela universidade: 〈http://www.uff.br $>$.

A Divisão de Relações Públicas orienta e realiza cerimoniais de eventos da UFF, enquanto a Divisão de Criação Gráfica é responsável pela idealização de grande parte do trabalho gráfico produzido pela universidade (UNIVERSIDADE FEDERAL FLUMINENSE, 2014).

\subsubsection{O modelo da Universidade Federal do Espírito Santo - UFES}

A Superintendência de Cultura e Comunicação (Supecc/UFES) foi criada em 2012, pelo Conselho Universitário. É um setor vinculado à administração central, responsável por articular, propor, coordenar e executar as ações desenvolvidas pela universidade nas áreas da cultura e da comunicação, tais como: promover e oferecer serviços e produtos culturais para a comunidade acadêmica e para a sociedade; gerenciar os espaços culturais da UFES; atuar na difusão do conhecimento científico e cultural; produzir e distribuir conteúdos jornalísticos e institucionais; promover o atendimento à imprensa local e nacional e gerir veículos públicos de comunicação (UNIVERSIDADE FEDERAL DO ESPÍRITO SANTO, 2015a).

A Supecc organiza a produção de suas atividades em duas secretarias - de cultura e de comunicação - que contam com núcleos, responsáveis pela execução em cada uma de suas áreas de atuação. Integram a Secretaria de Cultura da Supecc a livraria e editora da UFES (EdUFES), o Coral da UFES e espaços culturais - Galeria Espaço Universitário, Cine Metrópolis e o Teatro Universitário.

Compõem a Secretaria de Comunicação a Assessoria de Imprensa, a Seção de Jornalismo, a Seção de Divulgação Científica, o Núcleo de Produção de Conteúdo Institucional, a Divisão de Publicidade, a Rádio Universitária 104.7 FM e a TV UFES (UNIVERSIDADE FEDERAL DO ESPÍRITO SANTO, 2015a). 
A Assessoria de Imprensa produz e envia informações sobre as atividades e serviços da UFES aos veículos de comunicação, além de atender aos jornalistas que buscam a universidade a fim de obter informações para a produção de matérias. A Seção de Jornalismo produz textos e imagens de caráter informativo para os veículos de comunicação da UFES: Jornal Informa (semanal, com tiragem média de oito mil exemplares), Portal da UFES (inserção de notícias) e gestão dos perfis da UFES nas redes sociais. A Seção de Divulgação Científica tem a função específica de divulgar e tornar acessível a produção científica desenvolvida nos campi da universidade.

O Núcleo de Produção de Conteúdo Institucional produz textos e peças de comunicação que têm o objetivo de informar sobre os serviços da universidade e reforçar sua importância enquanto instituição no contexto socioeconômico. Também é responsável pela atualização do conteúdo institucional relacionado à administração universitária e às atividades de ensino pesquisa, extensão e assistência no portal da UFES na internet e em outros veículos de comunicação.

A Divisão de Publicidade é responsável pela produção de conteúdo publicitário da UFES. Produz a programação visual dos veículos impressos da Supecc.

A Rádio Universitária 104.7 FM dedica-se à produção, difusão e divulgação de notícias e dos bens culturais do Espírito Santo, por meio de programetes, informes, spots, entrevistas e programas musicais. A TV UFES funciona em caráter experimental, com a participação de alunos, técnicos e professores. Produz programas com conteúdos diversos, além de ser espaço para o conhecimento e a aplicação de novas linguagens em televisão. Os vídeos produzidos pela TV UFES estão disponíveis no canal Youtube da emissora: <http://www.youtube.com/user/TelevisaoUFES $>$ (UNIVERSIDADE FEDERAL DO ESPÍRITO SANTO, 2015a). 
Figura 5 - Organograma da Superintendência de Comunicação Social da UFES

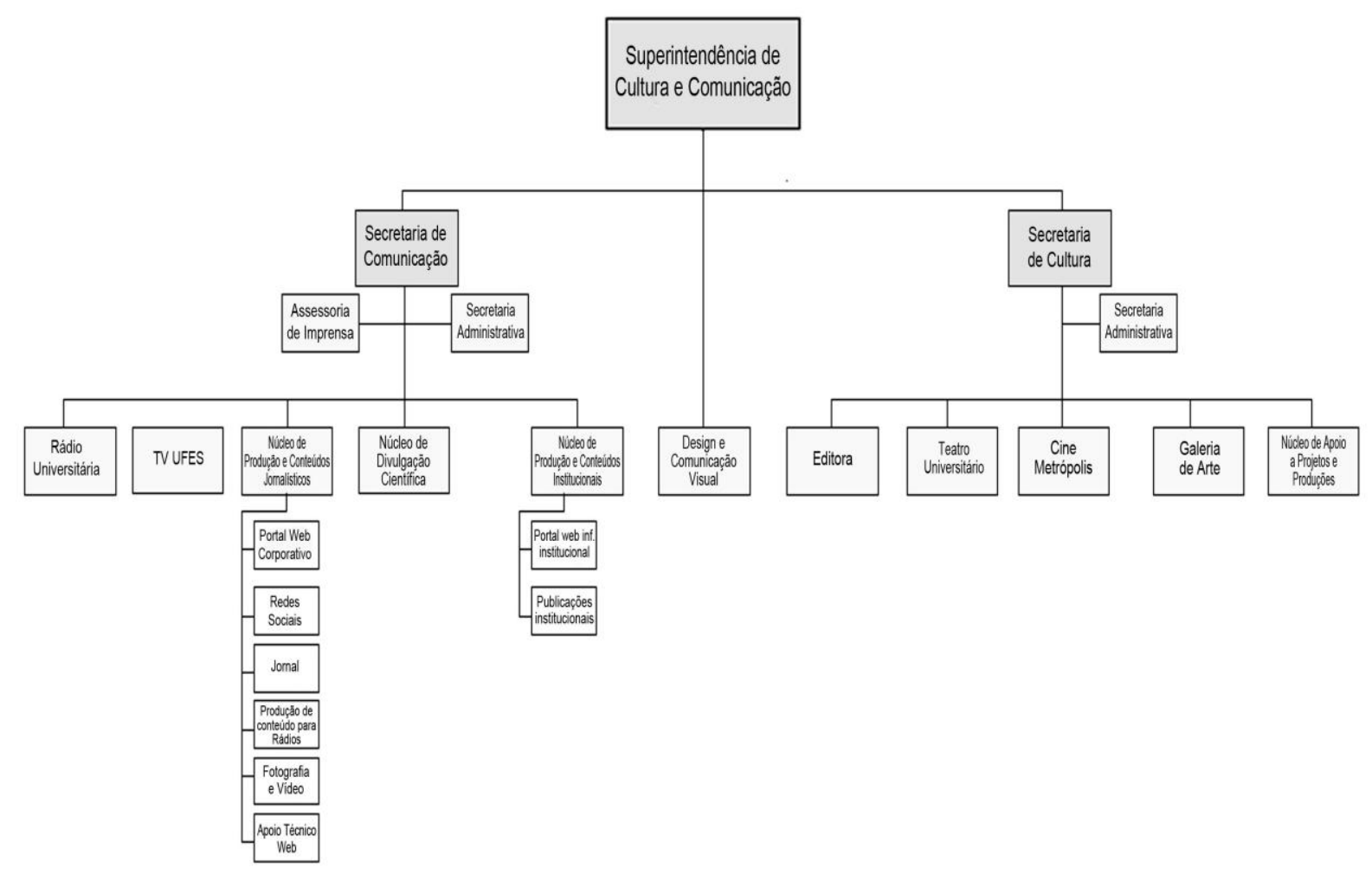

FONTE: UNIVERSIDADE FEDERAL DO ESPÍRITO SANTO, 2015b.

\subsubsection{O modelo da Universidade Federal do Piauí - UFPI}

A Superintendência de Comunicação Social (SCS/UFPI) é o órgão de direção subordinado diretamente à Reitoria da UFPI. Tem como principal atribuição planejar, criar, supervisionar, inspecionar e avaliar as diretrizes de uma política global de comunicação para a Universidade Federal do Piauí. A criação da SCS/UFPI deu-se pela Resolução n. ${ }^{\circ}$ 010/2013 do CONSUN/UFPI e ratificada pela Resolução 013/2013. A SCS/UFPI tem ascendência administrativa sobre as seguintes unidades: Gráfica Universitária da UFPI, Editora Universitária da UFPI, Coordenadoria de Comunicação, Rádio FM Universitária e TV Universitária - ainda em fase de implantação. Tendo em vista a natureza do trabalho, a SCS/UFPI colabora com a Ouvidoria. 
A Editora da Universidade Federal do Piauí (EDUFPI) tem como finalidade principal a difusão da produção científica da universidade, constituindo-se num canal de comunicação com a sociedade, bem como com a própria instituição.

A Gráfica Universitária da UFPI (GRAFUFPI) é um órgão singular oficialmente vinculado à SCS/UFPI. Visa desenvolver uma política de produtos de artefatos e serviços gráficos necessários ao uso institucional e que não possam ser divulgados por meios eletrônicos.

A Rádio FM Universitária 96,7 tem como missão oferecer ao público uma programação plural, ética e comprometida com práticas educativas, artísticas, culturais e informativas que possibilitem uma formação crítica, cultural e cidadã dos ouvintes, ao difundir conhecimentos e valores que contribuam para o desenvolvimento econômico, político, social e cultural do Piauí.

A Coordenadoria de Comunicação Social - COORDCOM é responsável pela gestão e fluxo de comunicação da instituição. A Coordenadoria atende às demandas da sociedade de forma interna e externa. Para tanto, utiliza meios de comunicação audiovisuais, sonoros, impressos, digitais e possui um site institucional <http://www.ufpi.br $>$ e perfis nas redes sociais para maior divulgação (UNIVERSIDADE FEDERAL DO PIAUÍ, 2015a).

Figura 6 - Organograma da Superintendência de Comunicação Social da UFPI

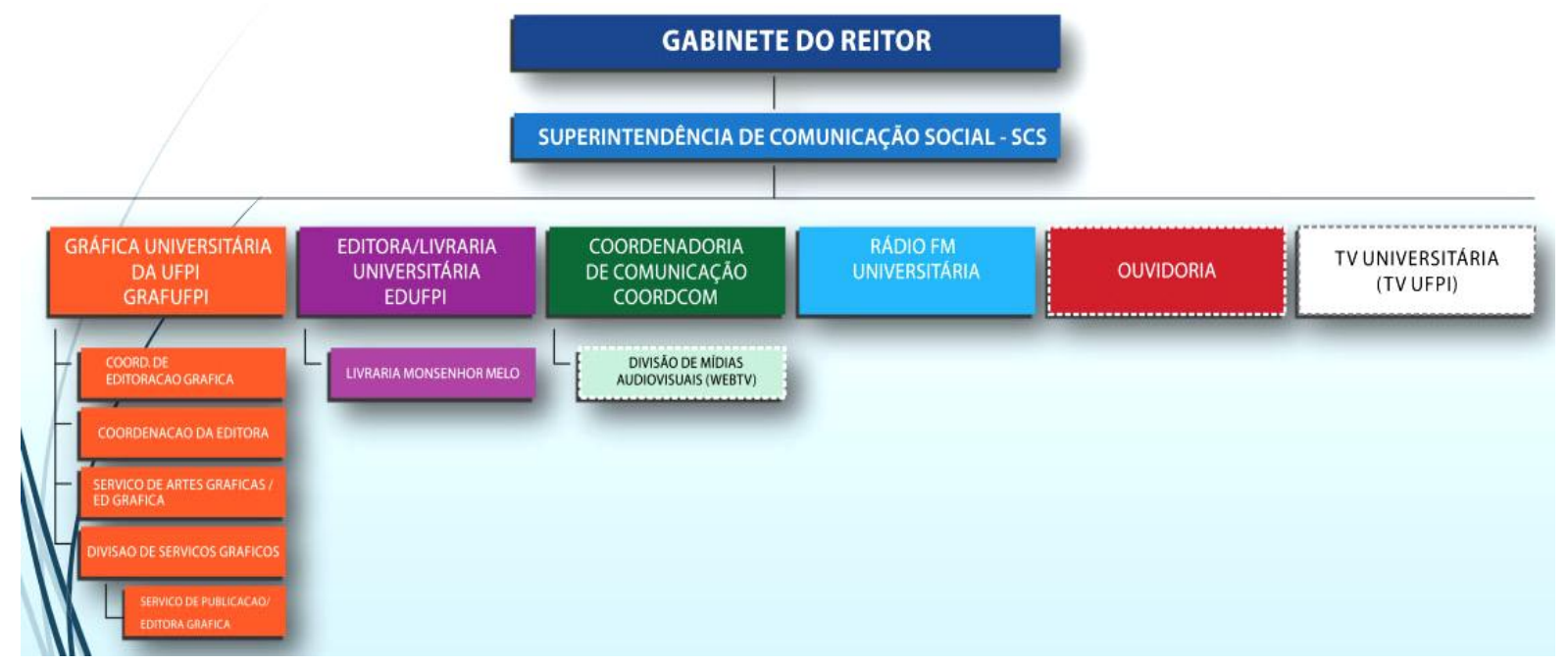

FONTE: UNIVERSIDADE FEDERAL DO PIAUÍ, 2015b. 


\subsubsection{O modelo da Universidade Federal do Rio Grande do Norte - UFRN}

Desde 1999 (Resolução n. ${ }^{\circ}$ 09/99 - Consuni), a Universidade Federal do Rio Grande do Norte (UFRN) dispõe de uma superintendência, na qual se encontram todas as unidades que oferecem/desenvolvem serviços no campo da comunicação social naquela universidade (UNIVERSIDADE FEDERAL DO RIO GRANDE DO NORTE, 2014).

Vinculada à Reitoria da UFRN, a Comunica - Superintendência de Comunicação tem como objetivo propor a política de comunicação interna e externa da Universidade do Rio Grande do Norte aos colegiados superiores e implementá-la. É sua atribuição, também, elaborar, gerenciar e supervisionar projetos, bem como desenvolver e manter os sistemas relacionados com a comunicação.

Segundo o seu Regimento Interno, a Comunica é dirigida por um servidor dos quadros da instituição, de nível superior, designado pelo reitor e aprovado pelo Conselho de Administração (UNIVERSIDADE FEDERAL DO RIO GRANDE DO NORTE, 2015).

Para o alcance de seus objetivos, a Comunica dispõe de um conselho consultivo e dos seguintes órgãos executivos: Diretoria da Agência de Comunicação, Diretoria da TV Universitária, Diretoria da Rádio Universitária, Gerência de Administração, Gerência de Promoção Institucional e Gerência Técnica. 
Figura 7 - Organograma da Superintendência de Comunicação da UFRN

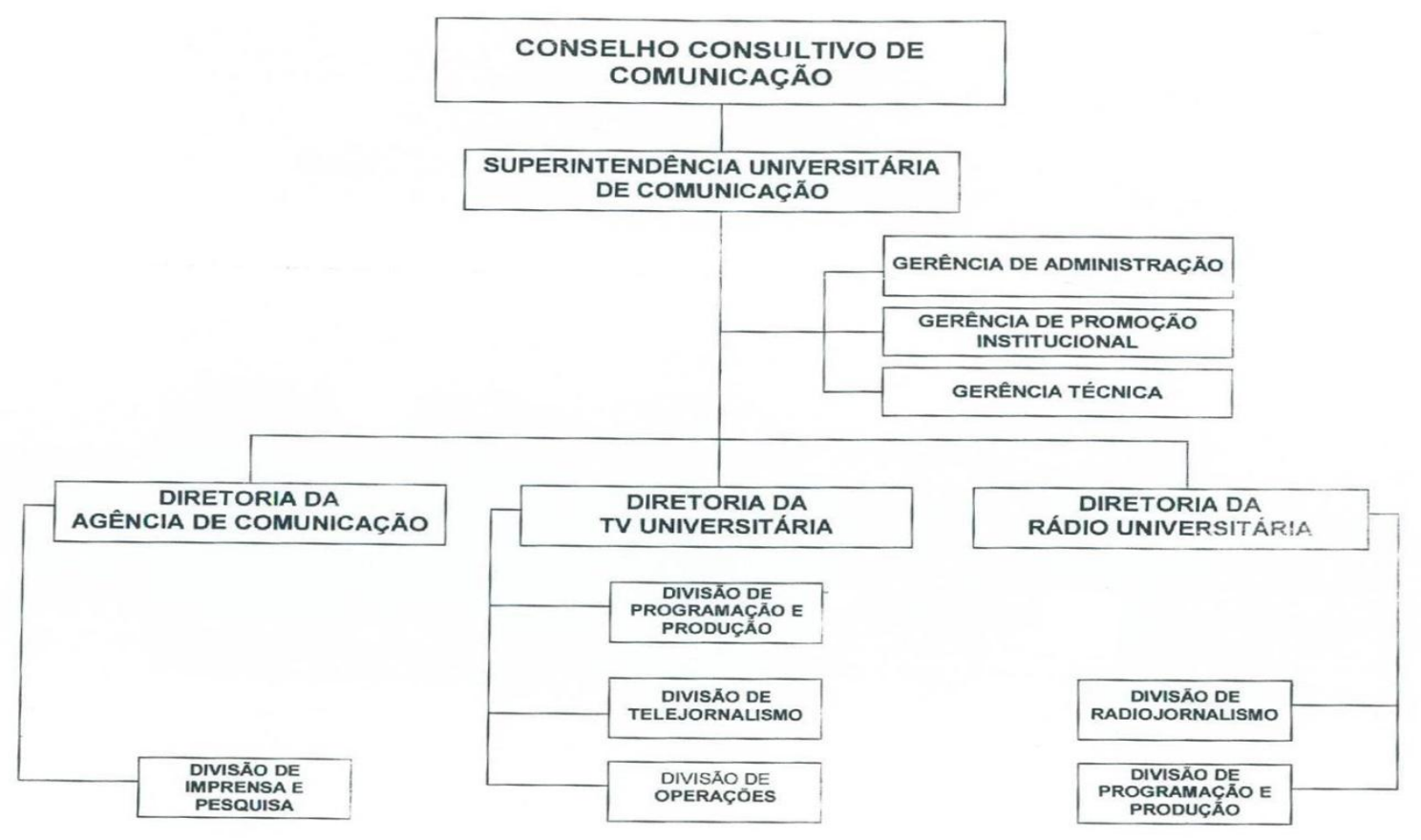

Fonte: UNIVERSIDADE FEDERAL DO RIO GRANDE DO NORTE, 2014.

O site da Comunica destaca os serviços da rádio, da TV e da Agência de Comunicação daquela universidade (UNIVERSIDADE FEDERAL DO RIO GRANDE DO NORTE, 2014).

Ao longo dos seus 38 anos, a TVU RN produz programas educativos, culturais e jornalísticos dos mais diversos formatos, além de campanhas educativas e de difusão cultural. A emisora veicula a programação da TV Brasil e contribui para a formação de estudantes de Comunicação Social da instituição, treinando também graduandos de diversas outras áreas.

Desde sua inauguração, em 2000, a Rádio Universitária 88,9 FM (FMU) tem contribuído para a disseminação da produção técnico-pedagógica-científica da UFRN e divulgado o patrimônio cultural regional, especialmente o do Rio Grande do Norte.

A Agência de Comunicação (AGECOM/UFRN) responsável pela comunicação institucional da UFRN. Busca produzir e difundir para a sociedade informações sobre 
conhecimentos, saberes, tecnologias e ações gerados nas áreas de ensino, pesquisa e extensão da universidade.

São os atuais meios de divulgação da Agência: Boletim Eletrônico UFRNotícias, com duas edições diárias; Boletim Eletrônico Matéria Especial, com duas edições semanais; Jornal da UFRN, com edição mensal (impressa e disponível eletronicamente); Redes Sociais; Portal da UFRN; Web TV UFRN - AGECOM; Web Radio UFRN - AGECOM; e blogs informativos de eventos periódicos e/ou sazonais.

A Agência de Comunicação articula ainda o relacionamento dos produtores de informação da UFRN com a imprensa em geral (e vice-versa), convoca entrevistas coletivas, sugere pautas, realiza a clipagem dos noticiários eletrônico e impresso, articula-se com as assessorias de imprensa de setores da universidade e organiza a memória noticiosa e fotojornalística da instituição (UNIVERSIDADE FEDERAL DO RIO GRANDE DO NORTE, 2014).

Na próxima unidade será analisada a estrutura de comunicação social da UnB, para, na sequência, apresentar a proposta de modelo de integração dos setores de comunicação da universidade (ANEXO A), a partir da criação de um órgão complementar, denominado Superintendência de Comunicação da UnB.

\subsection{Estrutura de comunicação da Universidade de Brasília}

Enquanto várias IES públicas integraram diferentes órgãos, setores e meios de comunicação com o objetivo de obter maior eficiência e sinergia em suas ações, a UnB tem mantido uma estrutura marcada pela separação, prevalecendo uma prática de atuação isolada das unidades integrantes da área e pela ausência de uma política de comunicação global. A própria distribuição dos setores de comunicação no organograma da UnB evidencia essa ausência de integração (ANEXO D). 
Para descrever a estrutura da comunicação da UnB, foram utilizados os seguintes documentos: o Estatuto e Regime Geral da Universidade de Brasília (UNIVERSIDADE DE BRASÍLIA, 2011); o Plano de Desenvolvimento Institucional (PDI) 2014-2017 da UnB (UNIVERSIDADE DE BRASÍLIA, 2015c), os relatórios de Autoavaliação Institucional da UnB - 2011, 2012, 2013 e 2014 (UNIVERSIDADE DE BRASÍLIA, 2014a; UNIVERSIDADE DE BRASÍLIA, 2014b; UNIVERSIDADE DE BRASÍLIA，2014c; UNIVERSIDADE DE BRASÍLIA, 2015a), a Lei n. ${ }^{\circ}$ 8.977, de 6 de janeiro de 1995 (BRASIL, 1995) e reportagem jornalística (ÚLTIMO SEGUNDO, 2015).

A análise de cada unidade de comunicação da UnB permite evidenciar a dinâmica que se estabeleceu ao longo dos anos e, dessa forma, é possível identificar os principais desafios desses setores, tendo como horizonte a atuação de forma integrada.

\subsubsection{CPCE/UnBTV}

O Centro de Produção Cultural a Educativa (CPCE) foi criado em 1986, quando o então Departamento de Comunicação, hoje Faculdade de Comunicação (FAC/UnB), teve participação decisiva na elaboração da estratégia e nos entendimentos que levariam à renegociação do convênio entre a UnB e a Fundação Roberto Marinho. O acordo resultou na liberação de verba necessária à implantação do CPCE (nos termos do convênio, a totalidade desse recurso seria destinada à Fundação Roberto Marinho, funcionando a UnB como mera intermediária). Graças ao recurso, foi possível criar uma estrutura básica de produção de vídeos (UNIVERSIDADE DE BRASÍLIA, 2014e).

O CPCE, desde a sua origem, procura ser um centro de referência para a produção audiovisual no Centro-Oeste. Desenvolve inúmeras coproduções, apoiando diversas iniciativas no campo da educação, da cultura e da arte. A produção para TV está direcionada a quatro campos de atuação: formação e atualização de profissionais, pesquisa, disseminação do 
conhecimento e captação de recursos por meio de prestação de serviços no campo audiovisual (UNIVERSIDADE DE BRASÍLIA, 2014b).

A partir de 2006, o CPCE passou a gerir a UnBTV, transmitida pela operadora NET Brasília, no Canal 15. A concessão do canal é prevista na Lei do Cabo (n. ${ }^{\circ}$ 8.977/95), que, em seu artigo 23, obriga as operadoras do serviço de cabo a tornar disponíveis determinados canais, chamados "Canais Básicos de Utilização Gratuita", entre os quais "um canal universitário, reservado para o uso compartilhado entre as universidades localizadas no município ou municípios da área de prestação do serviço" (BRASIL, 1995).

Conforme a Associação Brasileira de Televisão Universitária (ABTU), da qual a UnBTV é associada, televisão universitária é aquela

produzida por instituições de Ensino Superior (IES) e transmitida por canais de televisão (abertos ou pagos) e/ou por meios convergentes (satélites, circuitos internos de vídeo, internet, etc.) voltadas estritamente à promoção da educação, cultura e cidadania (MAGALHÃES, 2008, p. 1-2).

Peixoto e Priolli (2015, p. 5) acrescentam que a televisão universitária é feita com a participação da comunidade acadêmica, com programação diversificada.

\footnotetext{
Uma televisão voltada para o público interessado em cultura, informação e vida universitária, no qual prioritariamente se inclui, é certo, o próprio público acadêmico e aquele que gravita no seu entorno: familiares, fornecedores, vestibulandos, gestores públicos da educação, etc.
}

Embora a Lei do Cabo determine que o canal universitário deva ser compartilhado por universidades, é frequente o uso do sinal por apenas uma instituição, ou a realização de convênios que assegurem a participação de centros universitários e outras IES ou órgãos de pesquisa (RAMALHO, 2010).

No caso do canal universitário do DF, apesar das tratativas do CPCE/UnBTV para o compartilhamento do canal com outras instituições de ensino superior, apenas a UnB tem investido recursos financeiros e mantido a estrutura necessária para a manutenção da concessão. 
Somente no dia 13 de março de 2015, a UnBTV passou a existir formalmente na estrutura da UnB, por meio de ato da Reitoria (ANEXO E). Com a formalização, o canal universitário foi inserido oficialmente na estrutura organizacional do CPCE. É missão da UnBTV divulgar o ensino, a pesquisa e a extensão da UnB e difundir o conhecimento e a cultura (UNIVERSIDADE DE BRASÍLIA, 2014e).

Figura 8 - Organograma da UnBTV

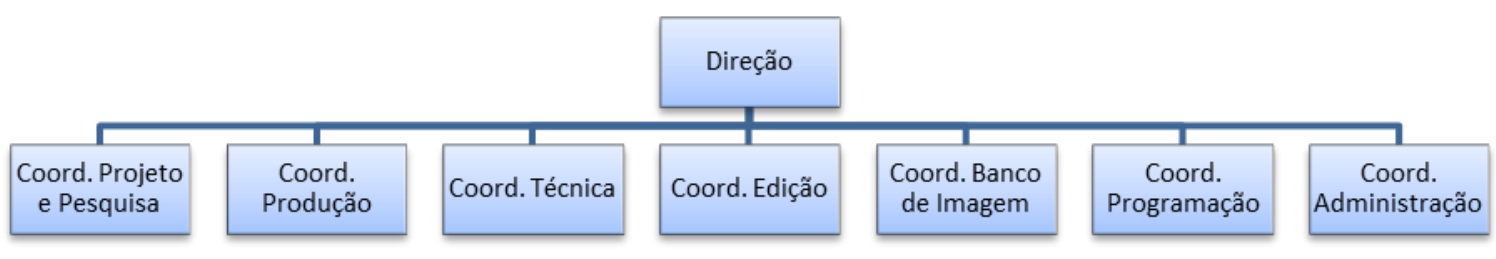

Fonte: Elaboração do autor

Uma característica importante da UnBTV é o fato de a emissora ter independência em relação à administração central da universidade, uma vez que é gerida pelo CPCE, e não pela Secom, embora isso não a exima de pressões institucionais (FARIA; PAULINO, 2015).

Além de ser transmitida pela TV a cabo, a programação da UnBTV também está disponível na internet: 〈http://www.unbtv.unb.br〉. O sinal na internet é veiculado, desde 2013, pela Rede Nacional de Ensino e Pesquisa (RNP) <http://www.rnp.br>.

A emissora conta atualmente com o seguinte quantitativo de pessoal:

Quadro 4 - Quantitativo funcional do CPCE/UnBTV

\begin{tabular}{|l|c|l|}
\hline & Quantitativo & \multicolumn{1}{c|}{ Cargo ocupado } \\
\hline Servidores & 21 & $\begin{array}{l}\text { 1 analista de TI, 3 assistentes administrativos, 1 auxiliar administrativo, 1 } \\
\text { auxiliar operacional, 1 diretor de imagem, 1 editor de publicação, 1 editor } \\
\text { de imagem, 1 eletricista, 3 jornalistas, 1 operador de luz, 1 operador de } \\
\text { câmera e TV, 1 produtor cultural, 1 psicólogo, 3 téc. audiovisual e 1 téc. } \\
\text { em eletrônica. }\end{array}$ \\
\hline Estagiários & 25 & Estagiários em graduação. \\
\hline
\end{tabular}

Fonte: Elaboração do autor. 
O CPCE/UnBTV funciona como um laboratório para estudantes de graduação, que formam grande parte da mão de obra da emissora (vide Quadro 4). Além disso, a emissora exibe produções de estudantes da Faculdade de Comunicação (FAC/UnB), como o Telejornal da FAC e o programa de entrevistas Dois Banquinhos.

A extinção das bolsas técnicas, em 2013, dificultou a contratação de profissionais qualificados para o aperfeiçoamento do programa de estágio (UNIVERSIDADE DE BRASÍLIA, 2014c). Além disso, em julho de 2015, a equipe da UnBTV foi reduzida de forma significativa, com a demissão dos prestadores de serviços (SICAP) da universidade para o cumprimento de acordo judicial celebrado em 2009 entre a Fundação Universidade de Brasília (FUB), o Ministério do Planejamento, Orçamento e Gestão (MPOG), o Ministério da Educação (MEC), e o Ministério Público do Trabalho (MPT) (UNIVERSIDADE DE BRASÍLIA, 2014c). Com isso, a emissora perdeu nove SICAP - cinegrafistas, operador de sistema de exibição, técnicos de audiovisual e técnico de micro-ondas - e aguarda a substituição, mesmo que parcial, desses técnicos por meio da realização de concursos públicos por parte da FUB.

Por meio da UnBTV, o CPCE tem buscado ampliar sua perspectiva inicial como produtor de filmes e vídeos, para se tornar um centro de teledifusão universitária, divulgando as produções realizadas por faculdades, institutos e centros da UnB (UNIVERSIDADE DE BRASÍLIA, 2014c). Um passo nesse sentido foi a criação, em 2013, de um núcleo de produção da UnBTV na Faculdade UnB Planaltina para cobertura de atividades daquele campus.

Uma das maiores dificuldades do CPCE/UnBTV tem sido a falta de verba. Apesar de vinculado à estrutura da Reitoria como unidade descentralizada que, em tese, pode captar recursos, o CPCE não tem autonomia financeira na gestão, nem na captação de recursos. 
Vários problemas de infraestrutura têm prejudicado a atuação do Centro ao longo de sua história. A inundação ocorrida em abril de 2011 no CPCE/UnBTV destruiu a secretaria do Centro e, consequentemente, os registros de autorização de uso de imagens, parcerias de produção e cessões de direito de todas as obras produzidas ao longo de quase trinta anos de funcionamento. Apesar dos danos e dificuldades, a UnBTV não deixou de operar. Transferida para uma sala de aula no Centro Interdisciplinar em Transporte (Ceftru), após alguns meses, retornou às antigas instalações, por questão de espaço (UNIVERSIDADE DE BRASÍLIA, 2014b).

Em 2012, o Centro sofreu outras inundações, quedas de energia e outros transtornos, ocorrendo perdas de equipamentos e de acervo, situações que fazem parte do cotidiano da unidade. Assim, o CPCE/UnBTV necessita de uma política de preservação de sua memória. (UNIVERSIDADE DE BRASÍLIA, 2014b).

O CPCE dispõe de um amplo banco de imagens sobre os mais diversos temas. Grande parte desse acervo jamais foi utilizada em vídeos editados, sendo, portanto, inédito. Para mantê-lo, são necessárias e urgentes instalações apropriadas e uma aproximação da unidade com os diversos setores que trabalham com metodologias e técnicas de preservação (UNIVERSIDADE DE BRASÍLIA, 2014b).

As instalações do CPCE/UnBTV são inadequadas para atividades de uma televisão, pois o local é insalubre, com mofos, goteiras e alagamentos (UNIVERSIDADE DE BRASÍLIA, 2015a).

Além disso, o Centro enfrenta dificuldades financeiras na execução de atividades típicas de um canal de TV, tais como: reparo imediato de equipamentos, aquisição de material de consumo destinado à produção ou mesmo aquisição de câmeras, ilhas de edição e outros instrumentos de trabalho (UNIVERSIDADE DE BRASÍLIA, 2014b). 
A aquisição de equipamentos tem esbarrado na demora do andamento de processos, dependentes de despacho de outros departamentos da UnB (UNIVERSIDADE DE BRASÍLIA, 2015a).

Entre os planos do CPCE está a obtenção de um canal digital aberto, o que implicará comprometimento da administração superior da UnB em assumir o custo dessa migração, incluindo aquisição de equipamentos, construção de um prédio adequado para abrigar uma TV com programação diária, 24 horas no ar (UNIVERSIDADE DE BRASÍLIA, 2014c).

\subsubsection{Rádio UnB}

A criação de uma Rádio UnB consta da estrutura organizacional da universidade. Conforme prevê o art. 41 do Estatuto da UnB, a emissora seria um dos órgãos complementares, além da TV (UNIVERSIDADE DE BRASÍLIA, 2011).

A concessão da Rádio UnB foi obtida em 1986, graças aos esforços do Departamento de Comunicação da UnB. Docentes e estudantes participaram ativamente desse processo. Entretanto, devido a um impasse jurídico, a Rádio UnB não está operando (ANEXO F).

A trajetória da Rádio UnB iniciou-se em 2004, quando um decreto legislativo concedeu à Fundação Universitária de Brasília (FUBRA) o canal 222 E (FM 92.3) de radiodifusão sonora, tipo educativo, em frequência modulada. Conforme relata o professor da Faculdade de Comunicação (FAC/UnB) Carlos Eduardo Esch (ANEXO F), a FUBRA foi escolhida para receber o canal por ser, à época, uma fundação controlada pela Reitoria da UnB. Em 2006, foi assinado convênio de cooperação com a FUBRA e adquiridos os equipamentos de transmissão da emissora, instalados na cobertura do shopping Top Mall, em Taguatinga, onde se encontram até o momento (ANEXO F).

Em 2009, a FUBRA se desvinculou da Reitoria da UnB, e após uma crise de ordem econômica e jurídica, o Ministério Público do DF, por meio da Procuradoria de Fundações, iniciou um processo no sentido de extingui-la, o que se deu entre 2011 e 2012. Diante disso, a 
UnB iniciou tratativas com o Ministério das Comunicações para evitar a perda do canal de rádio. A direção da FUBRA na época, entretanto, recusou-se a formalizar a devolução do canal. Com a decretação do processo de extinção pelo Ministério Público, o canal foi incorporado à massa falida da FUBRA, o que levou a um impasse. A UnB tem se mobilizado junto à Justiça Federal buscando a devolução do canal para o Ministério das Comunicações (ANEXO F)

Até o momento, a Rádio UnB não se constituiu como órgão complementar da UnB, conforme prevê o Estatuto da UnB, sequer tem orçamento próprio, e não está subordinada à unidade acadêmica. Ainda que as pendências judiciais sejam resolvidas, resta um problema grave a ser resolvido: a área onde foram instalados os estúdios, no subsolo do Instituto Central de Ciências (ICC/UnB), foi parcialmente destruída com as enchentes de 2011 (ÚLTIMO SEGUNDO, 2015). Toda a parede do estúdio principal precisa ser reconstruída, assim como o revestimento acústico. Há a necessidade de uma obra de infraestrutura que evite novos alagamentos no local devido à infiltração no solo. Vale ressaltar que a emissora, quando entrar em funcionamento, precisará de estrutura própria de pessoal para a produção de conteúdo, bem como de técnicos especializados. Além disso, será necessário dotá-la de orçamento próprio para produção e manutenção (ANEXO F).

\subsubsection{Secretaria de Comunicação}

A Secretaria de Comunicação (Secom), ligada ao gabinete do reitor, é responsável por informar a comunidade interna e externa sobre a produção científica e cultural da universidade, por divulgar os atos da administração e por zelar pela imagem de austeridade e de responsabilidade ética, intelectual e administrativa da UnB (UNIVERSIDADE DE BRASÍLIA, 2014d).

Também cabe à Secom divulgar o papel social da UnB e promover eventos e atividades que integrem estudantes, professores e servidores técnico-administrativos às 
funções de ensino, pesquisa e extensão da instituição. A gestão atual da Secom está pautada nos seguintes princípios: compromisso com a veracidade, zelo pela imagem da UnB, apartidarismo, economicidade, respeito à diversidade e valorização da comunidade acadêmica. O eixo de trabalho da Secom está centrado no serviço e na projeção da ciência (UNIVERSIDADE DE BRASÍLIA, 2014d).

É de competência da Secom a Assessoria de Imprensa, cujo objetivo é mediar o contato entre a imprensa e a comunidade acadêmica, por meio do gerenciamento do fluxo de informações entre fontes - professores, pesquisadores, mestrandos, doutorandos e servidores da administração superior da UnB - e veículos de comunicação (UNIVERSIDADE DE BRASÍLIA, 2014d).

Para o desenvolvimento das atividades de comunicação externa, a Secom utiliza os seguintes meios e instrumentos:

1. Portal UnB, principal página da UnB na internet 〈http://www.unb.br $>$, com conteúdo noticioso, dedicado a matérias relacionadas à UnB, e institucional, com informações sobre as atividades da administração da universidade. O Portal também divulga a produção acadêmica da UnB, os serviços oferecidos e relacionados à instituição e torna pública a ação da administração superior;

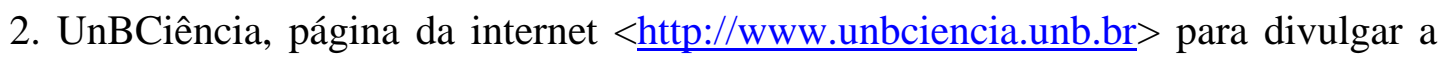
produção científica da universidade;

3. Redes Sociais, com publicações em canais oficiais da UnB no Facebook <http://www.facebook.com/universidadebsb $>$ e no Twitter 〈http://twitter.com/unbsecom $>$. São reproduzidas nas mídias as matérias que estão no Portal da UnB e produzidos textos mais curtos e dinâmicos;

4. Carta de Serviços ao Cidadão, cujo objetivo é informar o cidadão dos serviços prestados pela Instituição, das formas de acesso a esses serviços e dos respectivos 
compromissos e padrões de qualidade de atendimento ao público. Está disponível na página

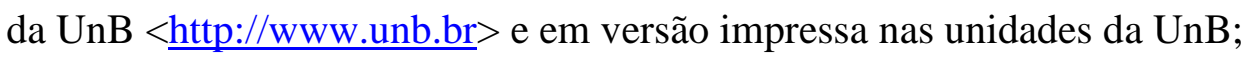

5. Clipping, uma compilação das matérias que saem na mídia sobre a UnB - em jornais, impressos e sites (UNIVERSIDADE DE BRASÍLIA, 2014d; UNIVERSIDADE DE BRASÍLIA, 2015a).

Para as atividades de comunicação com a comunidade interna, a Secom utiliza estas ferramentas:

1. UnB Hoje, informativo com a agenda das atividades realizadas nos quatro campi. Criado em 1985, é o mais antigo veículo de comunicação da UnB. Possui versão online e impressa: a primeira é enviada por e-mail aos usuários; a segunda é colocada em displays de acrílico, identificados pela cor verde e pela logomarca da UnB, espalhados pelos campi;

2. UnB Agenda, página eletrônica com as datas de eventos acadêmicos, disponível em <http://www.unb.br/eventos/maisevts $>$. Informa o título do evento, o cronograma e o local de realização, com link para informações adicionais;

3. Guia do Calouro, que apresenta a UnB ao estudante ingressante na cerimônia de boas-vindas. Também é disponibilizado no Portal da UnB (UNIVERSIDADE DE BRASÍLIA, 2014d; UNIVERSIDADE DE BRASÍLIA, 2015a).

A Secom é responsável, ainda, pela Gestão da Marca UnB, por meio de métodos que protegem e valorizam a imagem da universidade, buscando assegurar o uso correto da identidade visual (UNIVERSIDADE DE BRASÍLIA, 2014d).

Entre as atividades regulares promovidas pela Secom, destacam-se: a cerimônia de Boas-vindas; a campanha de recepção dos calouros, evento que inclui a Aula Magna, e o Parceiros da Imprensa, prêmio concedido anualmente aos profissionais da UnB que mais atendem às demandas da imprensa (UNIVERSIDADE DE BRASÍLIA, 2014d). 
Figura 9 - Organograma da Secretaria de Comunicação da UnB

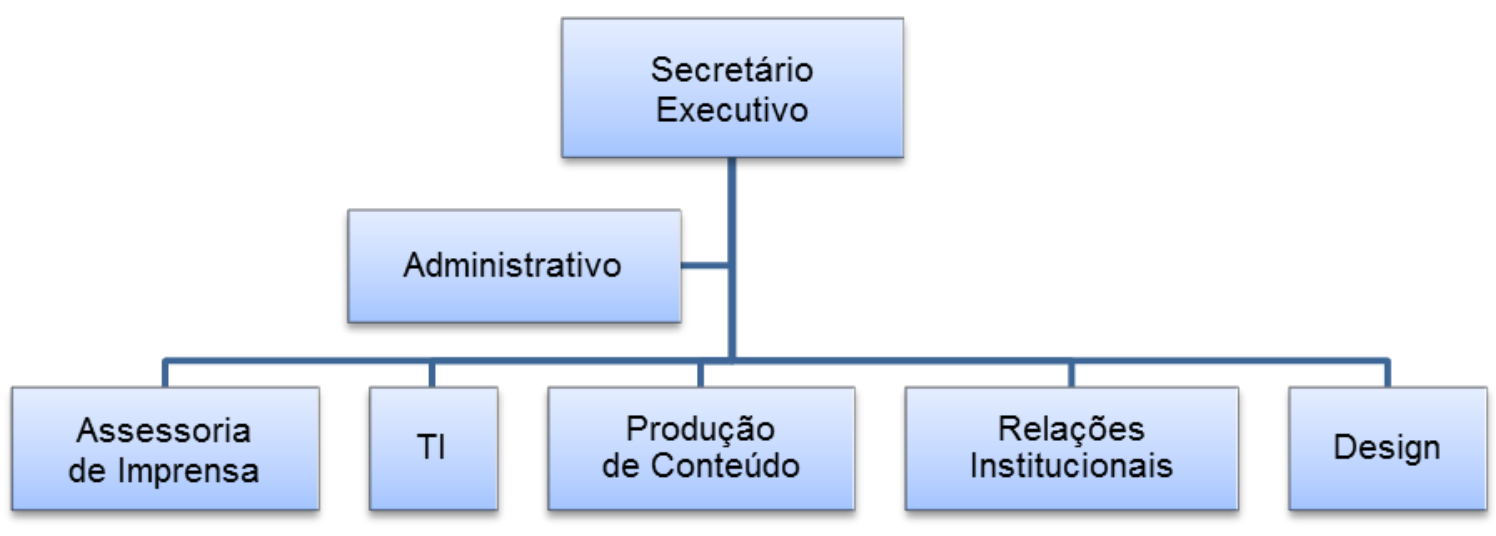

Fonte: UNIVERSIDADE DE BRASÍLIA 2014d.

Para o desenvolvimento de todas essas atividades, a Secretaria de Comunicação conta atualmente com o seguinte quantitativo: 15 servidores técnico-administrativos e oito estagiários. A Secretaria deixou de contar, em 2015, com 17 prestadores de serviços (SICAP).

Quadro 5-Quantitativo funcional da Secom

\begin{tabular}{|l|c|l|}
\hline & Quantitativo & \multicolumn{1}{c|}{ Cargo ocupado } \\
\hline Servidores & 16 & $\begin{array}{l}\text { 1 assistente administrativo, 1 contínuo, 1 fotógrafo, 6 jornalistas, 1 } \\
\text { produtor cultural, 1 programador, 2 publicitários, 1 relações públicas e } \\
2 \text { revisores. }\end{array}$ \\
\hline Estagiários & 8 & Estagiários em graduação. \\
\hline
\end{tabular}

Fonte: Elaboração do autor.

A Secom não possui autonomia administrativa, do ponto de vista da gestão de recursos financeiros e de pessoal, pois não se caracteriza como órgão complementar.

\subsection{Superintendência de Comunicação da UnB: processo de formação}

A comissão criada pela Resolução da Vice-Reitoria da UnB n. ${ }^{\circ}$ 04/2013 (ANEXO A), com o objetivo de formular um plano de articulação entre as diversas unidades de comunicação da universidade, apresentou uma proposta de Política de Comunicação Integrada para a Universidade de Brasília (ANEXO G). O documento prevê a criação de um órgão 
complementar, denominado Superintendência de Comunicação, que passaria a integrar, coordenar e supervisionar todas as unidades de comunicação existentes na UnB. Essa proposta baseou-se no Regimento Interno da Superintendência de Comunicação da UFRN (UNIVERSIDADE FEDERAL DO RIO GRANDE DO NORTE, 2015).

O Estatuto da UnB prevê, em seu capítulo $\mathrm{V}$, artigo 40, a criação de órgãos complementares aos quais competem realizar "atividades de caráter permanente de apoio, necessárias ao desenvolvimento do ensino, da pesquisa e da extensão" (UNIVERSIDADE DE BRASÍLIA, 2011).

Desde a criação da UnB, foi previsto que a Rádio e a Televisão Universitária deveriam se constituir como órgãos complementares, tendo em vista a especificidade de suas atividades, que exigem uma dinâmica administrativa-financeira autônoma e flexível.

Com o desenvolvimento de novos conceitos e perspectivas de gestão para a área, faz-se necessário atualizar a intenção do legislador à época, ocasião em que definiu as funções e atividades de um órgão complementar quando se trata da comunicação.

Ao aplicar o conceito de comunicação organizacional integrada, a Superintendência de Comunicação incorpora quatro dimensões de ação: 1) a integração de equipes que hoje gerenciam as unidades de comunicação da instituição; 2) a integração dos conteúdos a partir de uma política editorial unificada; 3) a integração dos processos e funções comunicacionais, compreendendo as atividades de todas as unidades envolvidas na gestão da produção de conteúdo; e 4) a integração da estrutura organizacional do ponto de vista administrativo e financeiro.

A Superintendência de Comunicação da UnB, a ser criada, tem como propósito coordenar as ações de todas as unidades de comunicação da universidade, além de estabelecer diretrizes para uma política de comunicação integrada, algo inexistente até o presente na UnB. 
O artigo 43 do Estatuto da UnB prevê que o órgão complementar seja gerido por um diretor, que responde administrativamente por este. $\mathrm{O}$ artigo seguinte especifica claramente a necessidade de um órgão dessa natureza constituir conselho deliberativo ou consultivo, na forma definida no seu regimento interno (UNIVERSIDADE DE BRASÍLIA, 2011).

Por sua vez, o Regimento da UnB estabelece, em seu artigo 40, as competências do diretor de órgão complementar: a) administrar e representar o órgão; b) convocar e presidir o Colegiado maior do órgão; c) zelar pela ordem e pela eficiência dos trabalhos; d) articular-se com as Unidades Acadêmicas cujas atividades sejam suplementadas pelo órgão; e) exercer atividades de fiscalização no ambiente do órgão; f) cumprir e fazer cumprir o regimento do órgão e as disposições estatutárias e regimentais aplicáveis; g) cumprir e fazer cumprir as instruções e as determinações do reitor e dos Conselhos Superiores; h) apresentar ao reitor relatório anual das atividades do órgão; i) assumir outras responsabilidades previstas no regimento interno do órgão (UNIVERSIDADE DE BRASÍLIA, 2011).

Dessa forma, como órgão complementar, vinculado à Reitoria da UnB, a proposta é que a Superintendência de Comunicação tenha as seguintes finalidades: a) coordenar, supervisionar e gerir as ações das unidades de comunicação com o propósito de dar coerência e unidade a identidade institucional por meio dos diferentes veículos e suportes utilizados pela UnB, além de integrar atividades e equipes profissionais e otimizar esforços e recursos; b) garantir condições para a efetiva divulgação às ações da UnB, resultantes de atividades acadêmicas de pesquisa e extensão sob os mais variados formatos e linguagens, para públicos diversos, com qualidade técnica e com ética e c) executar a política de comunicação da UnB estabelecida neste ato por meio da ação de suas unidades e do Conselho Consultivo (ANEXO G). Com base nesse dispositivo legal, a Proposta de Comunicação Integrada para a Universidade de Brasília prevê que a Superintendência de Comunicação da UnB (ANEXO G) 
tenha a seguinte estrutura organizacional: a) Superintendente, b) Conselho Consultivo, c) Conselho Diretor, d) Secretaria Administrativa, e) Assessoria de Projetos, f) Assessoria de Imprensa, g) Diretoria de Mídia Impressa e Digital, h) Diretoria da UnBTV e i) Diretoria da Rádio UnB.

Figura 10 - Organograma da Superintendência de Comunicação da UnB

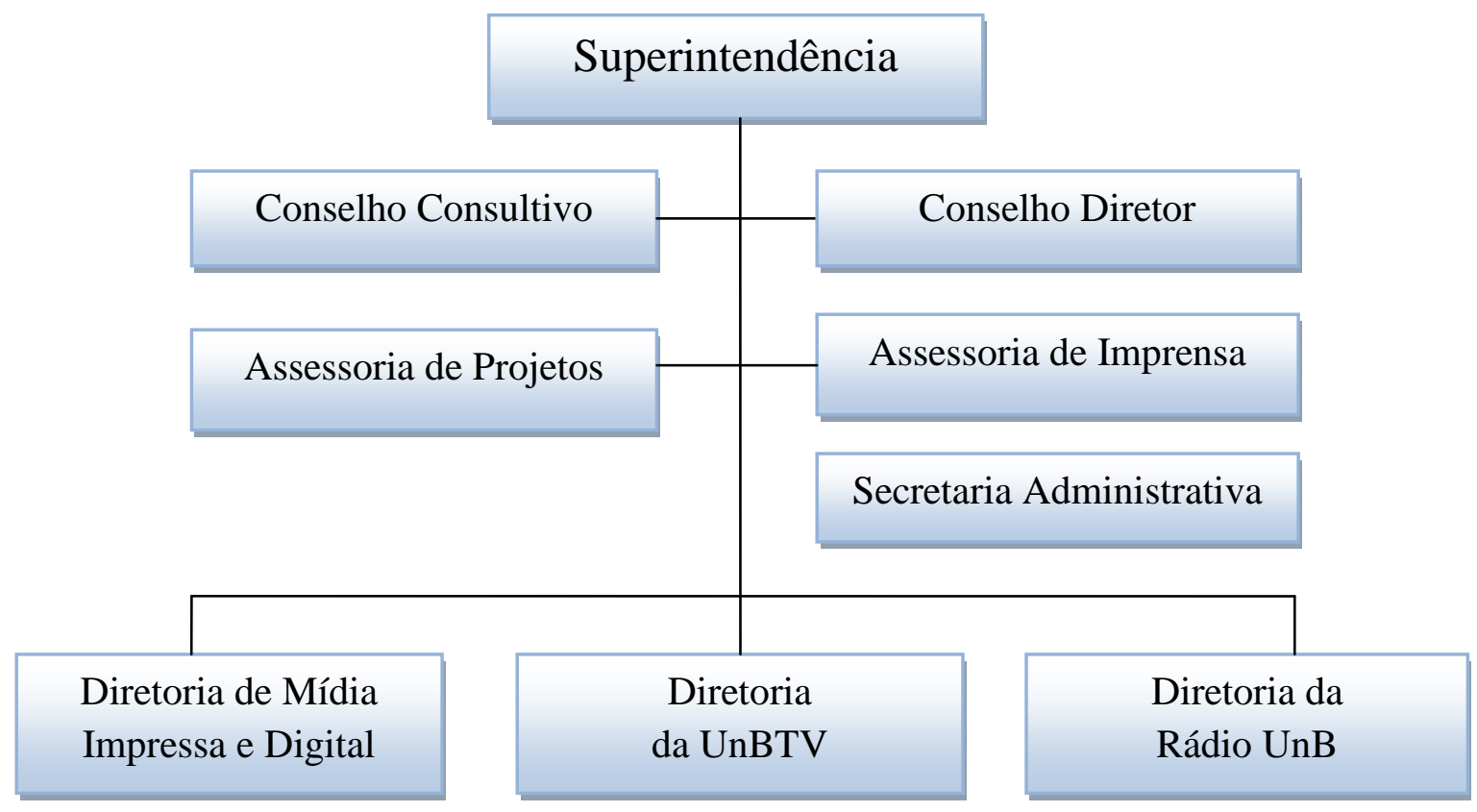

Fonte: Proposta de Política de Comunicação Integrada para a Universidade de Brasília (ANEXO G).

A proposta de criação da superintendência traz o detalhamento da estrutura da superintendência (ANEXO G).

No relatório final, optou-se por contemplar apenas as áreas diretamente envolvidas com a comunicação da UnB - Rádio, Secom e UnBTV. Outros setores poderão ser incluídos na proposta da Superintendência de Comunicação em uma próxima etapa (ANEXO C).

A integração das atividades de comunicação na UnB, por meio da criação de uma superintendência de comunicação, depende, em grande medida, da atuação conjunta dos profissionais da área, estando ou não fisicamente no mesmo espaço. Tal situação poderá garantir coerência da linguagem adotada, unificação de pauta e racionalização das atividades. 
O processo de integração é uma necessidade, tendo em vista a crescente redução do número de profissionais da área - devido à alta rotatividade, à demissão de prestadores de serviço e à baixa remuneração -, à ausência de reposição de pessoal e às condições estruturais precárias existentes nas unidades de comunicação da UnB.

Ressalte-se que a atual desintegração existente no campo da comunicação social na UnB decorre de uma visão de gestão universitária na qual se incentivou a atuação descentralizada de cada unidade, com perfil capaz de buscar e prover seus próprios recursos. Verifica-se, atualmente, a falta de uma política e de uma gestão que possam articular e acompanhar as iniciativas da universidade.

Entender essa situação ajuda a evitar que isso se repita e serve de orientação para se seguir um caminho oposto, em que prevaleça a sinergia e coordenação das ações no âmbito da comunicação da UnB. 


\section{Metodologia}

Este estudo insere-se na área de atuação Estado, Território e Políticas Públicas do Programa de Pós Graduação Profissional em Gestão Pública (PPGP/FUP/UnB), para analisar como a comunicação organizacional da UnB pode integrar os setores de comunicação da universidade, no âmbito da proposta da comissão instituída pela Resolução n. ${ }^{\circ}$ 04/2013 (ANEXO A), da Vice-Reitoria da UnB.

No contexto dessa área de investigação, a presente pesquisa desenvolve estudos empíricos sobre uma política pública que interfere na governança da comunicação social da Universidade de Brasília, a fim de analisar um mecanismo de inovação (a criação de uma superintendência de comunicação), o processo decisório, os arranjos institucionais e a participação social consequentes desse processo, no contexto da comunicação organizacional da UnB.

\subsection{Delineamento da pesquisa}

A pesquisa buscou identificar a percepção de especialistas em comunicação, profissionais da área e demais envolvidos na unificação dos setores de comunicação social da UnB, em uma pesquisa qualitativa, classificada como um estudo exploratório.

Conforme Collado, Lucio e Sampieri (2006), o enfoque qualitativo é usado para descobrir e tratar as questões de pesquisa, a partir da coleta de dados sem medição numérica, podendo ou não comprovar hipóteses no processo de interpretação.

A pesquisa qualitativa apresenta características específicas: a fonte direta dos dados é o ambiente natural e o investigador é o seu principal instrumento; os dados que o investigador recolhe são predominantemente descritivos; os investigadores que utilizam metodologias qualitativas privilegiam o processo em si não tanto os resultados; além disso, o investigador interessa-se, sobretudo, por tentar compreender o significado que os participantes atribuem às suas experiências (BOGDAN; BIKLEN, 1994). 
Conforme Alami, Desjeux e Garabuau-Moussaoui (2010), os métodos qualitativos possibilitam revelar dimensões que não são visíveis diretamente por meio de metodologia quantitativa. De acordo com esses autores, a abordagem qualitativa é mais bem adaptada, por exemplo, ao aproveitamento de novas oportunidades para uma organização, do que às ações de padronização no âmbito organizacional.

Particularmente, esta pesquisa qualitativa é um estudo exploratório, um estudo de caso, voltado para promover uma maior familiaridade com o assunto, por meio da exploração e construção das hipóteses concernentes ao objeto pesquisado.

Para Chizzotti (2000, p. 102), “o caso é tomado como unidade significativa do todo e, por isso, suficiente tanto para fundamentar um julgamento fidedigno quanto propor uma intervenção".

André (2005) afirma que o estudo de caso é o estudo da particularidade e da complexidade de um caso singular, derivando um conhecimento amplo e integrado. Neste estudo, a singularidade é a escolha por explorar o modelo de comunicação organizacional integrada no contexto da UnB.

O estudo de caso recorre a diversas técnicas no processo de recolha de dados, próprias da pesquisa qualitativa. No presente estudo, uma das técnicas escolhidas foi a entrevista semiestruturada. Outras técnicas utilizadas foram a análise documental e a observação na modalidade participante. Quanto ao procedimento para a discussão dos dados, foi adotada a análise de conteúdo, nos moldes de Bardin (2011).

A principal vantagem da utilização de múltiplas fontes informativas é o desenvolvimento de linhas convergentes de investigação, enquanto processo de triangulação de dados (YIN, 2005). A triangulação clarifica significados, na medida em que observações adicionais podem ser úteis na revisão da interpretação do investigador. É, também, uma das características de um bom estudo qualitativo (STAKE, 2007). 
A escolha do estudo de caso nesta pesquisa está coerente com as ideias de Yin (2005), uma vez que se analisa "como" se dará a integração do sistema comunicacional da UnB, além de buscar o "porquê" da necessidade de se criar uma instância que unifique as áreas de comunicação da universidade.

\subsubsection{Análise documental}

Neste estudo, foram analisados os seguintes documentos: o Estatuto e Regime Geral da Universidade de Brasília (UNIVERSIDADE DE BRASílIA, 2011); o Plano de Desenvolvimento Institucional (PDI) 2014-2017 da UnB (UNIVERSIDADE DE BRASÍLIA, 2015c); a Resolução da Vice-Reitoria n. ${ }^{\circ}$ 04/2013, que constitui comissão para formular e apresentar plano de articulação entre as diversas unidades de comunicação da UnB (ANEXO A); a Resolução da Vice-Reitoria n. ${ }^{\circ}$ 11/2013, que cria comissão para avaliar a proposta do plano de articulação apresentada pela comissão composta pela Resolução da Vice-Reitoria n. ${ }^{\circ}$ 04/2013 (ANEXO B); relato sobre a Rádio UnB (ANEXO C); a Proposta de Comunicação Integrada para a Universidade de Brasília (ANEXO G); o Regimento Interno da Superintendência de Comunicação da Universidade Federal do Rio Grande do Norte (UFRN) (UNIVERSIDADE FEDERAL DO RIO GRANDE DO NORTE, 2015), o qual serviu de modelo para a proposta de Superintendência de Comunicação da UnB, e a Lei n. ${ }^{\circ} 11.652$, de 7 de abril de 2008, que institui os princípios e objetivos dos serviços de radiodifusão pública explorados pelo Executivo (BRASIL, 2008).

Conforme Boni e Quaresma (2005), a investigação científica, baseada no levantamento de dados, deve principiar-se por uma pesquisa bibliográfica, seguida pela observação e por fim, entrar em contato com pessoas que forneçam dados ou fontes de pesquisa. 


\subsubsection{Entrevistas semiestruturadas}

A entrevista é um instrumento básico para a coleta de dados dentro do enfoque qualitativo, sendo uma das principais técnicas de pesquisa nas ciências sociais. De acordo com Ludke e André (1986), é necessário o preparo do entrevistador para não forçar uma resposta do entrevistado sem possibilitar a este liberdade de expressão.

A opção pelas entrevistas, em vez da aplicação de questionários, deve-se ao método adequar-se melhor à pesquisa, pois há oportunidade de obtenção de informações de forma mais flexível do que no questionário, em que as respostas estão restritas e pré-determinadas. Outra vantagem é que, na entrevista, existe a possibilidade de observação do entrevistado e do contexto (SELLTIZ; WRITSMAN; COOK, 1987).

Para os autores citados, a entrevista é mais vantajosa, por permitir o uso em quase todos os segmentos da população, já que a linguagem do entrevistador se adequará à do entrevistado. Além disso, esse método permite o direcionamento para o objetivo específico, sem diminuir a flexibilidade.

A escolha para esta pesquisa foi a realização de entrevistas semiestruturadas. Esse tipo de entrevista utiliza um roteiro de questões básicas, apoiadas “em teorias e hipóteses que interessam à pesquisa, e que, em seguida, oferecem amplo campo de interrogativas, fruto de novas hipóteses que vão surgindo à medida que se recebem as respostas do informante" (TRINIÑOS, 1990, p. 146).

Para as entrevistas, optou-se pela amostragem não-probabilística do tipo intencional, nos moldes de Patton (2002). Conforme Duarte (2012), a seleção é intencional quando o pesquisador escolhe conhecedores específicos do assunto.

Dessa forma, as entrevistas deste estudo foram aplicadas a gestores, servidores e estagiários que atuam na comunicação da UnB. Esse grupo foi selecionado por estar qualificado, pelo conhecimento empírico e/ou teórico da área de comunicação da UnB, para 
analisar a comunicação organizacional da instituição, bem como o processo de implantação da Superintendência de Comunicação da UnB.

As entrevistas, aplicadas individualmente, foram realizadas durante os meses de maio a agosto de 2015. O tempo médio de duração das entrevistas foi de 40 minutos.

Os questionamentos iniciais acerca do tema deram origem ao problema de pesquisa, formulado a partir de três funções: delimitação, clareza e precisão, conforme ensina Gil (2010). Em torno desses questionamentos, os objetivos também foram constituídos, os quais, por sua vez, originaram as categorias que nortearam esta pesquisa: Setores de comunicação da UnB, Gestão da comunicação da UnB, Superintendência de Comunicação da UnB, Comunicação organizacional integrada e Comunicação integrada em outras IES.

Estabelecido o problema, elaborados os objetivos, prontas as perguntas para as entrevistas, a pesquisa amparou-se nos estudos teóricos, na motivação e no interesse pelo tema para realizar a pesquisa e compor o estudo.

\subsubsection{Observação}

Conforme Cervo e Bervian (2002), observar é aplicar os sentidos a um amplo objeto, para dele adquirir conhecimento claro e preciso. Para esses autores, a observação é vital para o estudo da realidade e de suas leis. A observação também é compreendida como uma forma de obter informações sobre aspectos da realidade que se investiga. Essa técnica de pesquisa é utilizada ao lado de outros métodos, uma vez que possui vantagens e limitações (MARCONI; LAKATOS, 2004).

No presente estudo, foi utilizada a observação na modalidade participante, em que o pesquisador junta-se ao grupo estudado e transforma-se em um de seus membros, ao mesmo tempo em que se mantém observador (ALENCAR, 2000). Este pesquisador atua na comunicação da UnB e participou ativamente das discussões acerca do estabelecimento de uma superintendência de comunicação social na UnB, conforme modelos já adotados em 
outras IES públicas. Para o emprego da técnica de observação, foram destinadas cerca de 120 horas, em três meses de pesquisa de campo.

A seguir, buscar-se-á detalhar as características do universo e da amostra pesquisada.

\subsection{Amostra}

A pesquisa foi realizada nos setores da comunicação social da UnB e na Faculdade de Comunicação (FAC/UnB). As entrevistas (APÊNDICE B) foram direcionadas a docentes, servidores técnico-administrativos e um estagiário, todos da área de comunicação da UnB.

Nas entrevistas semiestruturadas, as perguntas foram do tipo flexível e semiestruturada, com o objetivo de permitir que os participantes se sentissem à vontade para discorrer sobre a comunicação da $\mathrm{UnB}$ e a implantação de uma superintendência de comunicação, momento em que o pesquisador pôde aproveitar para destacar aspectos e clarear pontos que ficaram obscuros ou omissos.

A entrevista foi previamente testada como piloto, aplicada a um(a) prestador(a) de serviço que atuava na área de comunicação da UnB. A supracitada entrevista não foi considerada para efeito de resultado, servindo apenas para validar os questionamentos. Dessa forma, buscou-se minimizar os erros na abordagem com os demais participantes.

Conforme Alami, Desjeux e Garabuau-Moussaoui (2010), pesquisas em ciências sociais oscilam de forma permanente entre a rigidez e a flexibilidade. A rigidez relaciona-se ao rigor metodológico inerente ao processo de pesquisa. Já a flexibilidade é intrínseca à abordagem qualitativa, exigindo do pesquisador uma adaptação ao campo. É por meio do campo, que ele entra na vida de pessoas que não o aguardavam, mas que aceitam acolhê-lo em seu quotidiano (ALAMI; DESJEUX; GARABAUAU-MOUSSOUI, 2010).

No âmbito da presente pesquisa, foi necessário decidir qual a direção a ser seguida e quais e quantas etapas devem ser realizadas, mas sem esquecer competências importantes em 
uma atividade qualitativa: a adaptabilidade, a maleabilidade e a flexibilidade (ALAMI; DESJEUX; GARABAUAU-MOUSSOUI, 2010).

\subsubsection{Sujeitos da Pesquisa}

$\mathrm{Na}$ escolha dos sujeitos entrevistados, optou-se por um grupo de participantes julgados capazes de dar informações confiáveis e relevantes para o tema e os objetivos da pesquisa Também foram levados em conta a praticidade e a disponibilidade dos entrevistados. Conforme Alves-Mazzotti (2001), o pesquisador escolhe o contexto e os participantes de sua pesquisa em função das questões de interesse do estudo, das condições de acesso e permanência no campo e da disponibilidade dos sujeitos.

A seleção dos entrevistados em estudos qualitativos depende do julgamento do pesquisador. Assim, é relevante que as fontes sejam consideradas não apenas válidas, mas também suficientes para responder à questão da pesquisa (DUARTE, 2012).

\footnotetext{
É importante obter informações que possam dar visões e relatos diversificados sobre os mesmos fatos. Pessoas em papéis sociais diferentes, recém-chegadas ou que tenham deixado a função recentemente, podem dar perspectivas bastante úteis. A relevância da fonte está relacionada com a contribuição que pode dar para atingir os objetivos de pesquisa (DUARTE, 2012, p. 69).
}

Neste estudo, foram entrevistadas onze pessoas envolvidas - direta ou indiretamente - com os setores de comunicação, entre estagiários, servidores técnico-administrativos, docentes e gestores da UnB. Os questionamentos buscaram explorar a experiência e os conhecimentos dos entrevistados para identificar de que forma a gestão da comunicação organizacional da UnB pode integrar os setores de comunicação social da universidade. Os participantes foram distribuídos e codificados de acordo com a função desempenhada e a área de atuação na comunicação da UnB, a saber: 
Quadro 6 - Sujeitos da pesquisa

\begin{tabular}{|c|c|}
\hline GE: & \\
\hline G1 & Reitoria \\
\hline $\mathrm{G} 2$ & CPCE/UnBTV \\
\hline G3 & Secom \\
\hline G4 & Secom/Comunicação Institucional \\
\hline DOP & \\
\hline D1 & FAC/Comunicação Organizacional \\
\hline D2 & FAC/Telejornalismo \\
\hline D3 & FAC e Rádio UnB \\
\hline D4 & UnBTV/parceiro \\
\hline SER & O-ADMINISTRATIVOS \\
\hline S1 & Secom \\
\hline $\mathrm{S} 2$ & UnBTV \\
\hline EST & \\
\hline E1 & UnBTV \\
\hline
\end{tabular}

Fonte: Elaboração do autor. 


\subsection{Análise da coleta de dados}

A análise foi feita por meio da coleta de dados, com entrevistas semiestruturadas, análise documental e observação. As técnicas aplicadas foram precedidas por uma compreensão preliminar da área de estudo. A partir dessa preparação, o pesquisador elaborou um roteiro com questões-chave flexíveis, de modo a permitir alterações e adaptações ao longo das entrevistas, valorizando o conhecimento dos participantes. Dessa forma, a lista de questionamentos originou-se dos objetivos da pesquisa, buscando tratar do tema de forma ampla e a mais aberta possível (APÊNDICE B).

O procedimento utilizado para as entrevistas foi a análise de conteúdo. Conforme explica Bardin (2009, p. 44), trata-se de "um conjunto de técnicas de análise das comunicações que utiliza procedimentos sistemáticos e objetivos de descrição do conteúdo das mensagens". Segundo a autora, a intenção da análise de conteúdo é a inferência de conhecimentos, que dizem respeito às condições de produção e que recorrem a indicadores, quantitativos ou não (BARDIN, 2009).

A inferência é definida por Franco (2008) como um procedimento que permite a passagem da descrição à interpretação, de forma controlada. No conteúdo da mensagem infere-se a concepção da realidade do participante, consciente ou ideologizada, o que pode ser filtrado mediante seu discurso (FRANCO, 2008).

$\mathrm{Na}$ análise de conteúdo, a presente pesquisa seguiu as diferentes fases recomendadas por Bardin (2011): pré-análise, exploração do material e tratamento dos resultados e interpretação. A primeira fase corresponde à organização com atividades abertas, tais como a leitura "flutuante" dos documentos a analisar, a escolha dos documentos e a referenciação dos índices - menções explícitas ou subjacentes de um tema em uma mensagem, a partir dos quais são construídos os indicadores. A fase seguinte consiste na aplicação sistemática das decisões 
tomadas anteriormente. Por fim, na terceira fase, procura-se tratar os resultados brutos de modo a torná-los significativos e válidos.

Buscou-se, dessa forma, explorar e aproveitar o material coletado nas entrevistas de modo a obter informações concretas sobre a comunicação organizacional da UnB e o processo de integração dos setores de comunicação social da universidade, no escopo da proposta final da comissão instituída pela Resolução n. ${ }^{\circ}$ 04/2013 (ANEXO A) da Vice-Reitoria da UnB.

No processo de categorização, recorreu-se novamente aos ensinamentos de Bardin (2011). Segundo a autora, um conjunto de boas categorias deve ter as seguintes qualidades: exclusão mútua, ou seja, um único princípio de classificação deve orientar a sua organização; pertinência, com categorias adaptadas ao material de análise escolhido e ao quadro teórico definido; objetividade, fidedignidade e produtividade. "Um conjunto de categorias é produtivo se fornece resultados férteis: em índices de inferências, em hipóteses novas e em dados exatos" (BARDIN, 2011, p. 150). Outrossim, as categorias foram extraídas dos objetivos específicos da pesquisa, a fim de comprovarem os aspectos concernentes ao objetivo geral. 


\section{Discussão dos dados}

As categorias, delineadas nos objetivos, foram: Setores de comunicação da UnB, Gestão da comunicação da UnB, Comunicação organizacional integrada, Comunicação integrada em outras IES e Superintendência de Comunicação da UnB.

Com a finalidade de alcançar os objetivos estabelecidos nesta investigação, as categorias foram subdivididas em variáveis, as quais emergiram das entrevistas semiestruturadas. As respostas dos participantes foram apresentadas em quadros. Na análise dos dados, recorreu-se à revisão de literatura, dialogando com as ideias dos autores já estudados.

\subsection{Categorias analisadas}

As categorias buscam analisar os dados coletados de acordo com a metodologia adotada nesta pesquisa. As respostas, obtidas na aplicação das técnicas, integram-se à literatura pertinente, expressa no referencial teórico.

A primeira categoria é Setores de comunicação da UnB, em que se descreve e analisa, a seguir, o cenário atual da gestão da comunicação na universidade.

\subsubsection{Setores de Comunicação da UnB}

O panorama atual da gestão da comunicação da UnB configura-se nos seguintes setores: Centro de Produção Cultural e Educativa - CPCE/UnBTV, Rádio UnB e Secretaria de Comunicação (Secom). As três áreas são vinculadas à Reitoria da UnB. Para o desenvolvimento do trabalho de comunicação interna e externa, a Secom e a UnBTV contam com equipes formadas por servidores técnico-administrativos e estagiários.

A Secom é responsável por informar sobre a produção científica e cultural da universidade, por divulgar os atos da administração e zelar pela imagem da UnB. Cabe, ainda, 
à Secretaria promover iniciativas que integrem a comunidade acadêmica às funções de ensino, pesquisa e extensão da UnB (UNIVERSIDADE DE BRASÍLIA, 2014d).

Figura 11 - Secretaria de Comunicação (Secom)

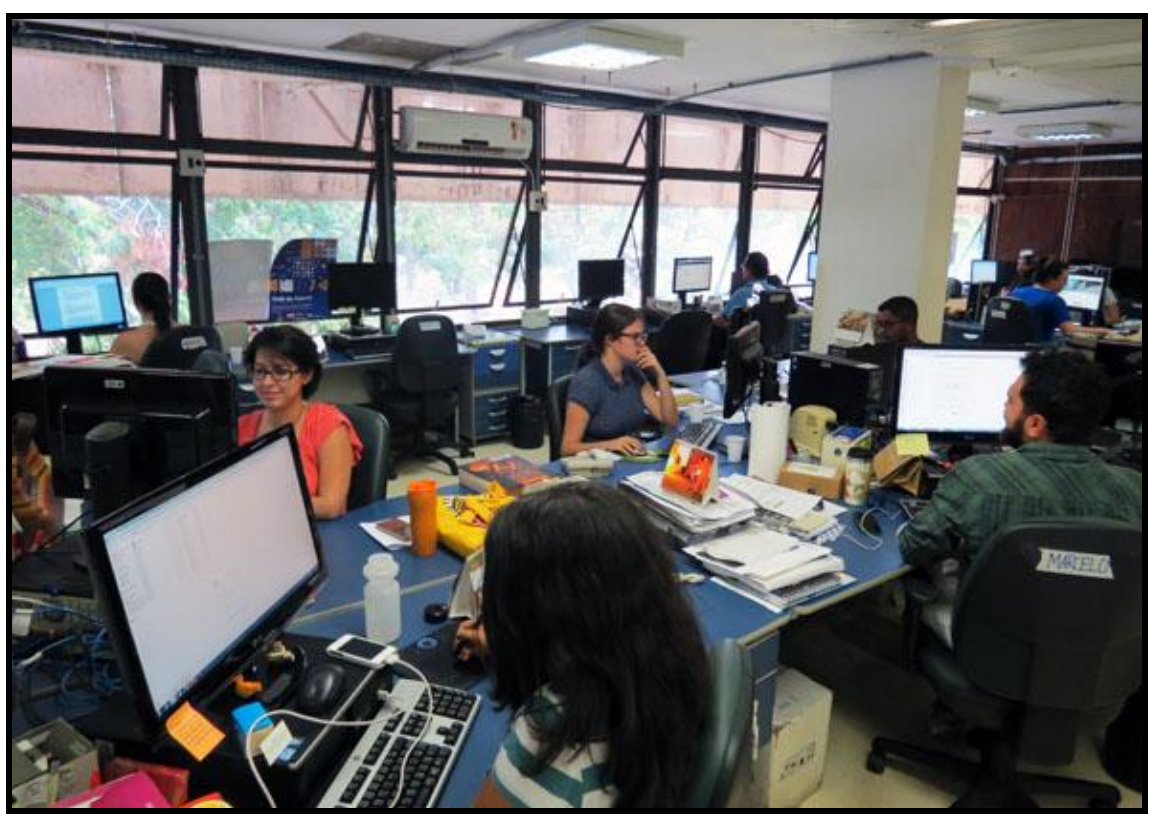

Fonte: Elaboração do autor.

Desde 2006, o CPCE opera a UnBTV, cuja missão é divulgar o ensino, a pesquisa e a extensão da UnB, difundir o conhecimento e a cultura, bem como contribuir para a formação de profissionais em audiovisual. (ANEXO E).

Figura 12 - CPCE/UnBTV

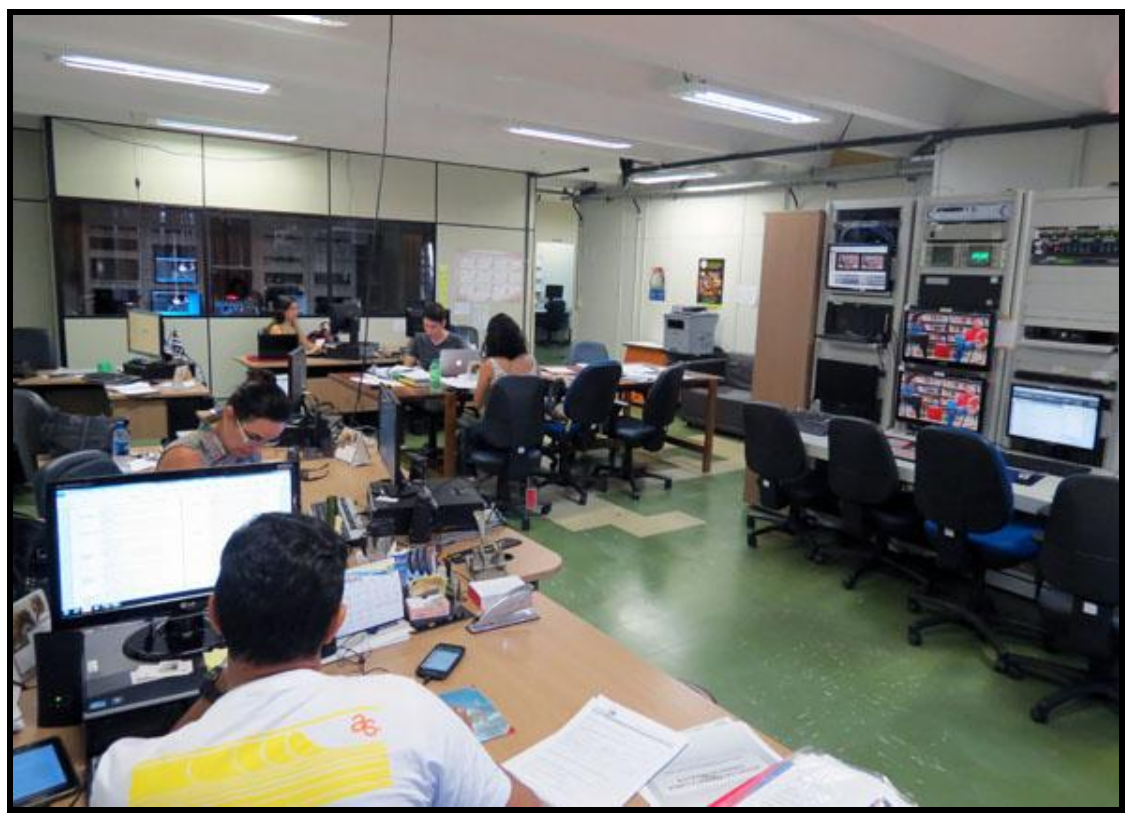

Fonte: Elaboração do autor. 
Figura 13 - UnBTV em Planaltina

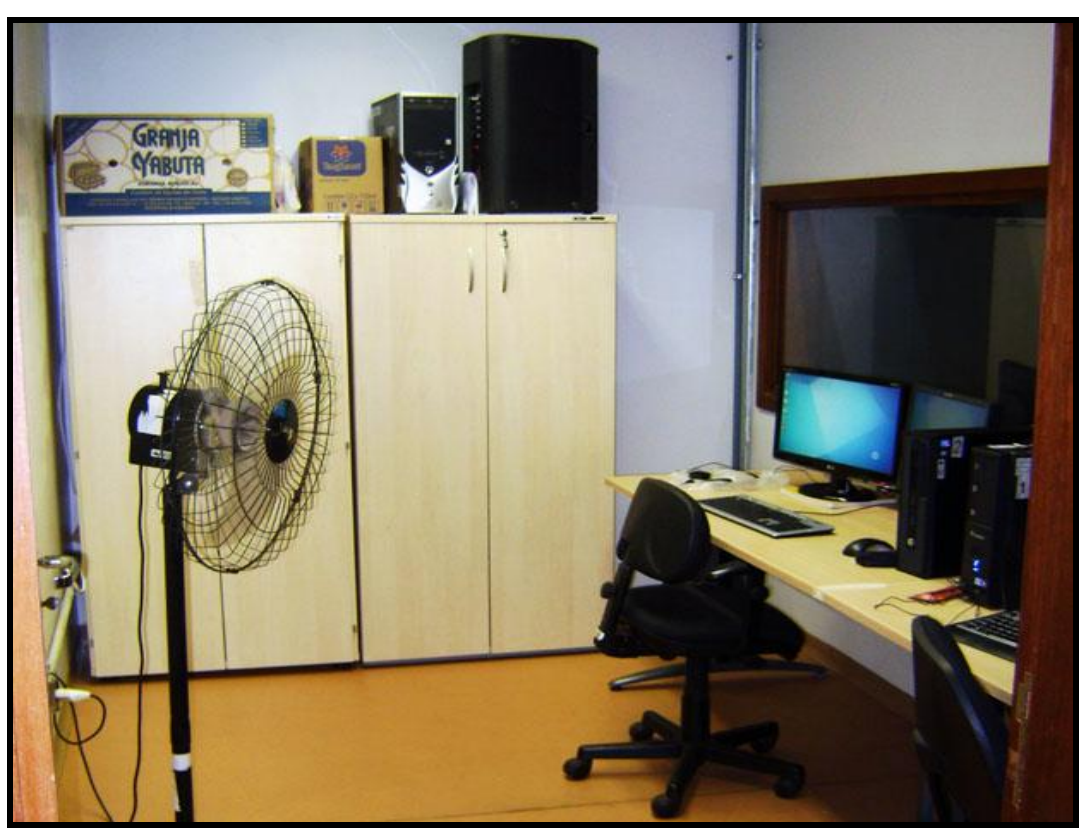

Fonte: Elaboração do autor.

A Rádio UnB foi idealizada para ser um órgão complementar da UnB. Apesar de contar com estrutura física e equipamentos, ainda não há possibilidade de se utilizar o canal na frequência 92.3, uma vez que faz parte da massa falida da FUBRA. Dessa forma, a Rádio UnB ainda não está operando (ANEXO F).

Figura 14 - Rádio UnB

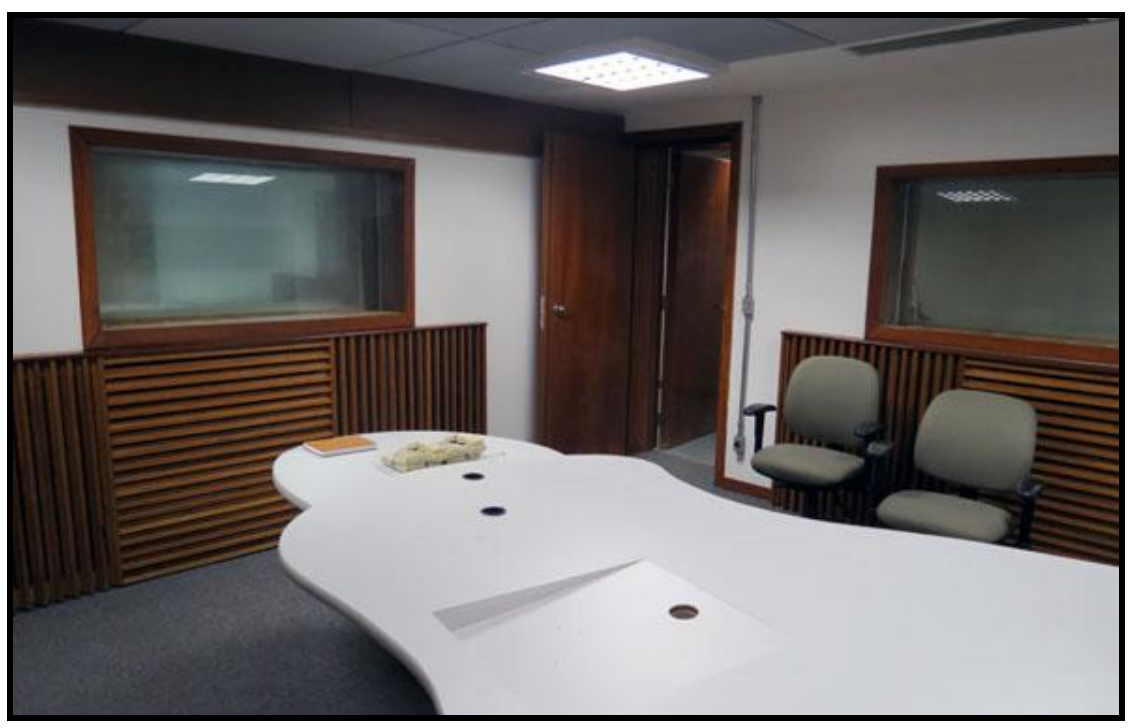

Fonte: Elaboração do autor. 
Esta primeira categoria foi subdividida em três variáveis: Conhecimento, Avaliação e Perspectivas. Tais variáveis foram eleitas a partir dos questionamentos das entrevistas semiestruturadas.

A primeira variável, Conhecimento, emergiu de três perguntas: 1) Você conhece os setores de comunicação da UnB?; 2) Você conhece os profissionais da área de comunicação da UnB? e 3) Quais instrumentos de comunicação da UnB você conhece, lê ou assiste? A segunda variável, Avaliação, foi criada a partir das respostas ao seguinte questionamento: Como você avalia a comunicação na UnB? Por fim, a variável Perspectivas resultou de opiniões dos sujeitos da pesquisa a respeito dos problemas e desafios da comunicação da UnB.

\subsubsection{Conhecimento sobre a Comunicação da UnB}

Em relação às áreas de comunicação da UnB, esta investigação buscou verificar quais são os setores e instrumentos comunicacionais de maior visibilidade entre os sujeitos da pesquisa. Constatou-se que todos os entrevistados conhecem a Secom e a UnBTV. Quanto à Rádio UnB, foi ressaltado que o canal poderia estar operando online. Entretanto, a Rádio está instalada em local insalubre e faltam profissionais para operar a emissora.

O Quadro 7 apresenta os instrumentos comunicacionais da UnB mais citados pelos participantes da pesquisa. 
Quadro 7 - Instrumentos de comunicação da UnB

\begin{tabular}{|c|l|}
\hline Entrevistado & \multicolumn{1}{|c|}{ Meios e canais de comunicação } \\
\hline G1 & Portal UnB e programas da UnBTV. \\
\hline G2 & Portal UnB, programas da UnBTV e canal Youtube da UnBTV. \\
\hline G3 & $\begin{array}{l}\text { Portal UnB, agência de notícias, Boas-vindas aos calouros, portal de Ciência, UnB Hoje e } \\
\text { programas da UnBTV. }\end{array}$ \\
\hline G4 & Portal UnB, UnB Hoje, programas da UnBTV e canal Youtube da UnBTV. \\
\hline D1 & Portal UnB, UnB Hoje, Boas-vindas aos calouros e programas da UnBTV. \\
\hline D2 & Portal UnB, programas da UnBTV e canal Youtube da UnBTV. \\
\hline D3 & Portal UnB e programas da UnBTV. \\
\hline D4 & Portal UnB, programas da UnBTV e canal Youtube da UBTV. \\
\hline S1 & $\begin{array}{l}\text { Portal UnB, UnB Hoje, agência de notícias, Boas-vindas aos calouros, programas da UnBTV e } \\
\text { canal Youtube da TV. }\end{array}$ \\
\hline E1 & Portal UnB, programas da UnBTV e redes sociais da UnBTV. \\
\hline
\end{tabular}

Fonte: Elaboração do autor.

Conforme observado (Quadro 7), o Portal UnB - <http://www.unb.br $>$ - e a programação da UnBTV são os instrumentos de comunicação da UnB mais citados pelos sujeitos da pesquisa.

O uso da comunicação online e das redes sociais é um aspecto ressaltado pelos entrevistados. Gestores e servidores entrevistados acompanham as transmissões ao vivo feitas pela UnBTV de eventos da universidade, por meio do site <http://www.unbtv.unb.br>. A maior parte dos participantes afirma acessar os conteúdos publicados nas redes sociais da UnBTV, especialmente no canal Youtube <http://www.youtube.com/unbtv>.

A maioria dos entrevistados relatou conhecer alguns profissionais de comunicação da UnBTV e da Secom.

Conforme verificado na observação qualitativa, há pouco envolvimento e compreensão das rotinas de trabalho entre as equipes da Secretaria de Comunicação e da UnBTV, o que contribui para a falta de sinergia entre as áreas. 


\subsubsection{Avaliação da Comunicação da UnB}

A pesquisa colheu as percepções dos participantes a respeito da comunicação da UnB, sintetizada no Quadro 8.

Quadro 8 - Avaliação da comunicação da UnB

\begin{tabular}{|c|l|}
\hline Entrevistado & \multicolumn{1}{|c|}{ Avaliação } \\
\hline G1 & Há grandes problemas na comunicação. \\
\hline G2 & É boa, mas há muito que melhorar. \\
\hline G3 & A Secom tem funcionado bem, mas ainda há muito a se fazer. \\
\hline G4 & $\begin{array}{l}\text { É muito boa, quando comparada a outras universidades. Mas falta melhorar muito em termos } \\
\text { técnicos, em conteúdo e estrutura. }\end{array}$ \\
\hline D2 & É muito centrada na relação com a imprensa. A comunicação interna precisa melhorar. \\
\hline D3 & É um problema histórico na UnB. \\
\hline D4 & É isenta e confiável. \\
\hline S1 & É um dos grandes gargalos na UnB. Precisa melhorar muito. \\
\hline S2 & Precisa melhorar muito. \\
\hline E1 & Tem muitos ruídos. Os comunicadores não sabem se comunicar. \\
\hline
\end{tabular}

Fonte: Elaboração do autor.

Conforme é possível perceber no Quadro 8, a maioria dos participantes avalia que a comunicação da UnB precisa melhorar, por apresentar problemas ou ruídos. Tal percepção vai ao encontro do diagnóstico institucional, publicado no PDI da UnB 2014-217 (UNIVERSIDADE DE BRASÍLIA, 2015b), o qual identificou, como ponto fraco da UnB, a fragilidade da comunicação interna e externa.

Parte dos entrevistados avalia que a comunicação da UnB é voltada para o público externo, em detrimento do público interno. Para D1, quase tudo ainda precisa ser feito na área de comunicação interna da UnB. 
“[...] sobretudo porque essa é uma área que geralmente fica meio que conduzida por cada unidade ou, então, nós temos aqueles sistemas de informação que vêm por e-mail que, na verdade, é só uma coletânea de mensagens e recados que as áreas vão mandando sem passar por triagem, desde informações de convocação para concurso, para projetos relevantes, até comunicação, sem uma hierarquização da informação" (Dl).

Em contrapartida, D2 avalia que a UnB se comunica bem com o público externo.

"Talvez pudesse comunicar mais, porque a gente vê muito viés de tratamento da UnB nos jornais, um viés perverso, digamos assim. Ou um viés que trata só por um lado. Mas eu acho que a universidade faz um esforço relevante de se comunicar com a sociedade. Já internamente eu acho a comunicação complicadíssima”(D2).

Gaudêncio Torquato (2015) destaca que as organizações têm buscado reforçar a comunicação interna, ajustando os meios comunicacionais para atingir uma comunidade de colaboradores cada vez mais crítica, qualificada e consciente de seus direitos - o que se aplica ao público-alvo da UnB.

\subsubsection{Perspectivas da Comunicação da UnB}

O Quadro 9 apresenta a percepção de cada entrevistado em relação às perspectivas da comunicação da UnB, envolvendo problemas e desafios. 
Quadro 9 - Perspectivas da comunicação da UnB

\begin{tabular}{|c|c|}
\hline Entrevistado & Perspectivas: problemas e desafios \\
\hline G1 & $\begin{array}{l}\text { - Melhorar a organização da UnB; } \\
\text { - Falta envolvimento da comunidade interna. }\end{array}$ \\
\hline G2 & $\begin{array}{l}\text { - Faltam mais profissionais e valorização dos servidores; } \\
\text { - Melhorar a infraestrutura e as instalações da UnBTV e da Rádio UnB; } \\
\text { - Falta maior valorização da UnBTV; } \\
\text { - Transmitir a UnBTV pelo canal digital e aberto; } \\
\text { - Integrar os setores de comunicação. }\end{array}$ \\
\hline G3 & $\begin{array}{l}\text { - Falta uma política clara de comunicação; } \\
\text { - Ampliar a equipe de profissionais; } \\
\text { - Reformular o Portal UnB; } \\
\text { - Melhorar a comunicação interna; } \\
\text { - Integrar os setores de comunicação. }\end{array}$ \\
\hline G4 & $\begin{array}{l}\text { - Faltam mais profissionais e valorização dos servidores; } \\
\text { - Falta mais conhecimento da comunidade interna sobre o funcionamento da comunicação na } \\
\text { UnB; } \\
\text { - Aprimorar os fluxos e procedimentos relacionados à comunicação na UnB; } \\
\text { - Criar condições para que os servidores possam também informar o que acontece na UnB; } \\
\text { - Integrar os setores de comunicação. }\end{array}$ \\
\hline D1 & $\begin{array}{l}\text { - Investir mais na comunicação interna, com integração das equipes, mobilização e } \\
\text { aprimoramento dos instrumentos de divulgação; } \\
\text { - Integrar os setores de comunicação. }\end{array}$ \\
\hline D2 & $\begin{array}{l}\text { - Melhorar os instrumentos de comunicação para o público interno; } \\
\text { - Falta mais envolvimento da comunidade da UnB nos processos de comunicação. }\end{array}$ \\
\hline D3 & $\begin{array}{l}\text { - Faltam mais profissionais de comunicação, do quadro efetivo, na Secom e na UnBTV; } \\
\text { - Reforçar a marca UnB; } \\
\text { - Integrar os setores de comunicação. }\end{array}$ \\
\hline D4 & $\begin{array}{l}\text { - Falta mais apoio; } \\
\text { - Falta maior divulgação interna; } \\
\text { - Integrar os setores de comunicação. }\end{array}$ \\
\hline S1 & $\begin{array}{l}\text { - Faltam mais profissionais de comunicação; } \\
\text { - Faltam equipamentos de trabalho; } \\
\text { - Integrar os setores de comunicação. }\end{array}$ \\
\hline S2 & $\begin{array}{l}\text { - Faltam mais profissionais e valorização dos servidores; } \\
\text { - Atuar mais nas redes sociais; } \\
\text { - Melhorar a infraestrutura da UnBTV; } \\
\text { - Falta maior formalismo na UnBTV; } \\
\text { - Reforçar a marca UnB; } \\
\text { - Integrar os setores de comunicação. }\end{array}$ \\
\hline E1 & $\begin{array}{l}\text { - Falta mais investimento; } \\
\text { - Melhorar o conteúdo transmitido; } \\
\text { - Integrar os setores de comunicação. }\end{array}$ \\
\hline
\end{tabular}

Fonte: Elaboração do autor.

Conforme o Quadro 9, grande parte dos entrevistados atribui as falhas e dificuldades da comunicação da UnB à falta de integração e articulação entre os setores. Na percepção desses participantes, ainda prevalecem ações isoladas. 
Enquanto D2 e G4 elogiam o design e o conteúdo do Portal da UnB, S2 avalia que este deveria ser mais dinâmico e funcionar como uma agência de notícias, com foco na produção de conteúdo e na divulgação da produção acadêmica. Para tanto, o(a) servidor(a) da UnBTV defende o uso das novas tecnologias:

\begin{abstract}
"[...] a universidade tem cada vez mais que romper os muros, ou seja, utilizar os recursos e as tecnologias que permitam às pessoas terem acesso aos professores, ou ao conteúdo desses professores, e eles terem um maior envolvimento com quem está fora da universidade. Afinal, a universidade pauta boa parte, ou tem um posicionamento importante, sobre temas que estão sendo discutidos no país. É importante que ela se faça cada vez mais presente e, sobretudo, com tecnologia" (S2).
\end{abstract}

Para D3, o Portal UnB precisa ser fortalecido, pois é o espaço de maior visibilidade dos produtos de comunicação da UnB. G1 avalia que o Portal é razoável, mas há pouco interesse da comunidade interna em relação ao conteúdo publicado.

Castells (2003, p. 287) afirma que vivemos atualmente numa sociedade em rede, dominada pelo poder da internet: “A internet é o coração de um novo paradigma sociotécnico, que constitui na realidade a base material de nossas vidas e de nossas formas de relação, de trabalho e de comunicação". Entretanto, o autor aponta falhas no uso da rede pelas organizações, em especial no âmbito da comunicação pública. Segundo o autor, instituições governamentais utilizam a internet, sobretudo, como um quadro de avisos eletrônicos para divulgar sua informação, sem se esforçar em obter uma interação efetiva.

Nessa perspectiva, gestores e servidores da Secretaria de Comunicação e da UnBTV, participantes da pesquisa, destacam que a Secom precisa compartilhar mais os vídeos do canal Youtube da UnBTV no Portal da UnB e atuar melhor nos espaços das redes sociais. G4 e D1 sugerem a criação de canais compartilhados, que permitam às pessoas enviarem conteúdos gravados em vídeos, o que reforça a "democracia de conteúdos", nas palavras de Torquato do Rego (2015). Segundo o autor, a soma das inteligências individuais pode estar criando uma “inteligência coletiva", ditando novos padrões culturais e de mídia. Para as organizações, esse 
cenário projeta a criação de dois perfis de usuários: os colaborativos e os raivosos, estes com baixo interesse em informação (TORQUATO DO REGO, 2015).

A programação da UnBTV foi elogiada por gestores e docentes participantes da pesquisa, pelo conteúdo e caráter experimental da emissora. Já E1 critica a falta de inovação e considera o conteúdo da UnBTV muito institucional: "poucos estudantes teriam o interesse em ficar ligados na UnBTV”.

Ao se analisar a programação da UnBTV, percebe-se que os formatos mais utilizados são programas discursivos e argumentativos, tais como entrevistas e palestras realizadas na UnB. A programação contempla diversos temas: política, cinema, literatura, música, entre outros (UNIVERSIDADE DE BRASÍLIA, 2014b).

Segundo Priolli (2004), a programação das TVs universitárias é marcada por um “desequilíbrio de gêneros”, em decorrência das características da instituição universitária e ao baixo orçamento dessas emissoras.

\footnotetext{
Sendo o reino da palavra por excelência, o território privilegiado dos discursos, a universidade sente-se mais à vontade - e talvez cumpra melhor a sua finalidade quando se utiliza de debates, entrevistas e palestras para comunicar-se pela TV. Mas se deve considerar, também, e de forma muito objetiva, que esses são os formatos de produção mais simples e barata que a televisão oferece (PRIOLLI, 2004).
}

Mazzioti (2002) defende que as TVs públicas busquem se diferenciar do segmento comercial, elaborando programas nos quais predomine a contextualização dos temas. Na mesma direção, S2 avalia que a UnBTV deveria ter a capacidade de explorar, em primeira mão, o conteúdo de especialistas e pesquisadores da UnB. Essa tarefa tem esbarrado na falta de recursos financeiros e na falta de profissionais da área, substituídos por estagiários - o que, muitas vezes, acarreta na produção de conteúdos superficiais.

Essa carência de profissionais levou a Secom a realizar um mapeamento de comunicadores da UnB que atuam em outros setores. Conforme o(a) gestor(a) da Secom entrevistado(a), foram identificados 19 comunicadores, entre estagiários, jornalistas, designer 
gráfico e fotógrafo, espalhados pelas unidades da UnB. Para D1, essa iniciativa é um avanço, tendo em vista a redução do quadro de profissionais de comunicação na UnB. D1 avalia que o levantamento é importante para identificar essas pessoas e, depois, treiná-las e capacitá-las. D3 ressalta a necessidade de um trabalho de convencimento junto a esses profissionais para engajá-los na construção de uma comunicação participativa. Nessa mesma perspectiva, Cabral (2011) afirma que é preciso melhorar as habilidades comunicacionais dos funcionários, capacitando-os, e atualizando-os para uma atuação mais competente e responsável em seu novo papel na organização e na sociedade.

O Quadro 10 apresenta o quantitativo atual (2015) de profissionais e estagiários que atuam na área de comunicação, incluindo o mapeamento de profissionais da área de comunicação que trabalham em outras unidades da UnB.

Quadro 10 - Quantitativo de profissionais e estagiários que atuam na comunicação da UnB

\begin{tabular}{|c|c|c|c|c|}
\hline & CPCE/UnBTV & Secom & Outras unidades & Total \\
\hline Servidor & 21 & 16 & 17 & 54 \\
\hline Estagiário & 25 & 8 & 2 & 35 \\
\hline \multicolumn{2}{|l|}{} \\
\hline
\end{tabular}

Fonte: Elaboração do autor.

Vale frisar que a UnBTV perdeu, em 2015, nove prestadores SICAP; a Secom, 17, e as demais unidades, um - os quais não constam do Quadro 10.

Outra solução criativa da Secom à falta de pessoal, segundo um gestor (G3) e um servidor (S1) da Secretaria entrevistados, foi a contratação de uma empresa júnior de comunicação para produzir matérias de divulgação científica.

Também foi apontada, nas entrevistas, a falta de valorização dos servidores técnicoadministrativos, em especial na UnBTV. Segundo informação do(a) gestor(a) da TV entrevistado(a), os coordenadores não recebem gratificação. Para esse(a) gestor(a), o problema da emissora é que ela já nasceu marginalizada, pois não foi idealizada de forma 
institucional, mas sim, por um grupo de pessoas. Dessa forma, a UnBTV continua a sofrer com a falta de infraestrutura, equipamentos, investimentos e pessoal qualificado. S2 destaca que a UnBTV carece de uma maior articulação com as unidades.

Vale ressaltar a percepção de alguns entrevistados de que é preciso fortalecer a “identidade UnB”. Para D3, “a marca UnB sempre esteve vinculada a uma atuação da Secom, quando, na verdade, ela deve permear todas as ações da comunicação".

Conforme é possível perceber das respostas dos participantes, os desafios da comunicação da UnB estão relacionados, em grande medida, a falhas no planejamento, assunto da próxima categoria.

\subsubsection{Planejamento da Comunicação da UnB}

Neste item, pretende-se examinar o panorama do planejamento estratégico aplicado à comunicação organizacional no âmbito das universidades públicas brasileiras, em especial da UnB. Para explorar os dados recolhidos, com base nas entrevistas semiestruturadas, esta segunda categoria foi subdividida em duas variáveis: Avaliação e Perspectivas. A primeira, Avaliação, foi criada a partir das respostas aos seguintes questionamentos: 1) Como você conceitua planejamento?; 2) Qual é a importância do planejamento? e 3) Como você avalia o planejamento atual da comunicação da UnB? Já a variável Perspectivas foi criada a partir dos desdobramentos desta indagação: Qual é a importância do planejamento nos níveis estratégico, tático e operacional na comunicação na UnB?

\subsubsection{Avaliação do Planejamento da Comunicação da UnB}

O Quadro 11 sintetiza a percepção dos participantes quanto ao planejamento atual da comunicação da UnB. 
Quadro 11 - Avaliação do planejamento atual da comunicação da UnB

\begin{tabular}{|c|l|}
\hline Entrevistado & \multicolumn{1}{|c|}{ Avaliação } \\
\hline G1 & Falta planejamento a médio e longo prazo. \\
\hline G2 & Falta um planejamento estratégico que integre os setores de comunicação. \\
\hline G3 & Está no gerúndio: estamos pensando a superintendência. \\
\hline G4 & Falta um planejamento estratégico. \\
\hline D1 & Desconhece a existência de um planejamento estratégico na UnB. \\
\hline D2 & Pode ser melhorado, mas funciona. \\
\hline D3 & Ainda não se alcançou o nível estratégico. Está longe disso. \\
\hline D4 & Falta um planejamento estratégico. \\
\hline S1 & É falho. \\
\hline S2 & Falta um planejamento estratégico. \\
\hline E1 & Falta planejamento no nível macro. \\
\hline
\end{tabular}

Fonte: Elaboração do autor.

De acordo com o Quadro 11, é possível perceber que todos os participantes da pesquisa consideram importante planejar as ações, a médio e longo prazo, e apontam que há falta de planejamento na comunicação da UnB. Quatro participantes da pesquisa afirmam que têm aprendido sobre planejamento mais na experiência prática do que em teoria. Foi possível perceber a insegurança de alguns entrevistados em relação ao tema planejamento nos níveis estratégico, tático e operacional.

A maioria dos entrevistados aponta que falta um planejamento estratégico de comunicação na UnB, pois os setores atuam de forma ainda desarticulada. Na percepção dos sujeitos da pesquisa, a partir de um macroplanejamento seria possível potencializar os recursos que a UnB dispõe para alcançar os seus objetivos e mostrar o que a universidade produz, reforçando a função de formadora de opinião da universidade e a importância da UnB para a sociedade. Para a maioria dos entrevistados, a Secom e a UnBTV têm atuado mais no nível tático e operacional do que no estratégico. 
Conforme D3, a comunicação da UnB ainda não alcançou o nível estratégico por falta de uma coordenação maior.

\begin{abstract}
“[...] Você só tem o estratégico quando consegue olhar para além do seu departamento. Para dizer assim: 'onde estamos, aonde queremos chegar?'. Esse aonde queremos chegar, que significa pensar o futuro, não me parece ainda ter sido algo organizado no sentido de construir esse planejamento estratégico. A UnB ainda está longe disso. Ela teria que pensar como vai se relacionar com seu público externo, o que ela quer, qual imagem ela quer projetar. E essa construção ainda não existe. Aonde quer chegar, estabelecer suas estratégias, estabelecer metas e, tudo isso, em função de posicionamento. [...]Essa estratégia maior ainda não foi construída" (D3).
\end{abstract}

Nessa mesma linha, Kunsch (2003) avalia que a comunicação estratégica agrega valor às organizações, auxiliando no cumprimento de sua missão, na consecução de seus objetivos maiores e na fixação dos seus valores, a partir de princípios éticos. Dessa forma, a comunicação deixa de ter uma função apenas tática e passa a ser considerada, de fato, estratégica. Passa a se confundir com a própria estratégia da organização (CARDOSO, 2006). Mintzberg (2004, p. 27-28) destaca que o planejamento é “o uso do procedimento formal e a existência de resultado articulado, especialmente no que diz respeito a um sistema integrado de decisões".

A percepção dos entrevistados quanto à falta de um planejamento estratégico de comunicação será explorada e aprofundada no próximo tópico.

\title{
7.1.2.2 Perspectivas do Planejamento da Comunicação da UnB
}

O Quadro 12 apresenta a percepção dos sujeitos da pesquisa quanto às perspectivas do planejamento da $\mathrm{UnB}$ - principais problemas e desafios. 
Quadro 12 - Perspectivas do planejamento da comunicação da UnB

\begin{tabular}{|c|c|}
\hline Entrevistado & Perspectivas: problemas e desafios \\
\hline G1 & - Falta garantia de recursos, o que dificulta uma maior versatilidade. \\
\hline G2 & $\begin{array}{l}\text { - Falta garantia de recursos; } \\
\text { - Falta interesse dos setores de comunicação em discutir o planejamento; } \\
\text { - Integrar os setores de comunicação. }\end{array}$ \\
\hline G3 & $\begin{array}{l}\text { - Criar um macroplanejamento; } \\
\text { - Rever as ferramentas e criar outras. }\end{array}$ \\
\hline G4 & - Buscar o que une as pessoas. \\
\hline D1 & - Planejar uma comunicação integrada. \\
\hline D2 & $\begin{array}{l}\text { - Pode ajudar a fortalecer a marca UnB; } \\
\text { - Podem ser pensadas novas estratégias. }\end{array}$ \\
\hline D3 & $\begin{array}{l}\text { - Construir um planejamento estratégico, ao qual façam parte o tático e o operacional; } \\
\text { - Estabelecer metas; } \\
\text { - Investir mais em marketing, relacionando-se com os públicos interno e externo a partir da } \\
\text { imagem que se quer projetar. }\end{array}$ \\
\hline D4 & $\begin{array}{l}\text { - Pensar que tipo de imagem e informações a UnB quer transmitir à sociedade; } \\
\text { - Dimensionar os recursos humanos e equipamentos; } \\
\text { - Estabelecer diretrizes de pauta; } \\
\text { - Administrar as equipes de forma a ter qualidade e produtividade; } \\
\text { - Integrar os setores de comunicação. }\end{array}$ \\
\hline S1 & $\begin{array}{l}\text { - É preciso criar um planejamento estratégico, com a chancela da alta administração, ouvindo } \\
\text { as áreas de comunicação. }\end{array}$ \\
\hline S2 & $\begin{array}{l}\text { - Definir critérios para as pautas; } \\
\text { - Evitar a duplicação de esforços; } \\
\text { - Definir metas e sistema de avaliação; } \\
\text { - Integrar os setores de comunicação. }\end{array}$ \\
\hline E1 & - Criar e difundir o planejamento estratégico. \\
\hline
\end{tabular}

Fonte: Elaboração do autor.

Em linhas gerais, os participantes entendem que o planejamento da comunicação da UnB deve avançar na seguinte perspectiva: 1) estrategicamente bem traçado, possibilitando aos setores de comunicação trabalhar em conjunto, otimizando os trabalhos; 2) taticamente orientado, discutindo mais as pautas, divulgando as produções da UnB e aproximando-se da sociedade; e 3) operacionalmente eficiente, atendendo às demandas mais imediatas com agilidade.

Nesse sentido, para gestores e docentes entrevistados, a UnB precisa investir mais em marketing, relacionando-se com os públicos interno e externo a partir da imagem que ela quer projetar. D3 considera que a UnB pode ser lembrada pela sociedade de forma muito 
positiva, tendo em vista a qualidade do ensino e sua importância social: "Ela tem traços e elementos importantes para se trabalhar uma boa estratégia de marketing. Mas, no entanto, ela falha muito na divulgação daquilo que ela pesquisa, daquilo que faz". D2 ratifica que a comunicação tem papel fundamental no fortalecimento da imagem da UnB.

Nessa mesma direção, Neves (2000) afirma que, para uma organização manter a sua credibilidade, precisa desenvolver, fortalecer e proteger os atributos positivos da imagem e neutralizar os negativos. O autor faz algumas recomendações voltadas para empresas, mas que poderiam ser adaptadas a instituições públicas: ter bons produtos e serviços; ser bem administrada, com gerência e processos modernos; ser um bom lugar para trabalhar, oferecendo carreira, remuneração competitiva, respeito, qualidade de vida, entre outros atributos, e ter valor agregado para a sociedade.

Nesse contexto, D1 avalia que uma área de comunicação se legitima aproximando-se mais do negócio da organização - no caso da universidade, o ensino, a pesquisa e a extensão "com tudo o que isso traz de diversidade e complexidade".

Neves (2000) avalia que a imagem de uma organização pode ser desenvolvida e protegida por meio de um sistema de comunicação integrada. Da mesma forma, G2 e D3 consideram que, a partir do estabelecimento de um planejamento estratégico de comunicação na UnB, que integre os três setores (Secom, Rádio e UnBTV), poder-se-á chegar também a um plano de comunicação, que permeie as ações da UnB.

Para a construção de um plano estratégico de comunicação, Kunsch (2003) aponta três eixos fundamentais: 1) pesquisa e construção de diagnóstico estratégico da organização; 2) planejamento estratégico da comunicação organizacional e 3) gestão estratégica da comunicação organizacional. Na primeira etapa, segundo a autora, busca-se conhecer a missão, os valores e o ambiente no qual está inserida a organização, por meio de levantamento detalhado de dados. A segunda etapa envolve a definição da missão, da visão e dos valores da 
comunicação, estabelecimento de filosofias e políticas, determinação de objetivos e metas, esboço das estratégias gerais, relacionamento dos projetos e programas específicos e montagem do orçamento geral. Por fim, a gestão estratégica da comunicação organizacional é a fase de sensibilização, envolvendo a divulgação do plano, a implementação, o controle das ações e a avaliação dos resultados (KUNSCH, 2003).

No caso da UnB, a Missão e a Visão de Futuro estão expressas no PDI/UnB 20142017. Segundo a análise ambiental da UnB, inclusa no PDI 2014-2017, a imagem institucional da UnB é um ponto forte. O documento aponta fragilidade da comunicação interna e externa. Nos objetivos e estratégias deste PDI, a comunicação é incluída na área de Recursos Tecnológicos, misturada à área de Tecnologia da Informação (TI). As estratégias para a área são: estabelecer política de comunicação e informação integradas; mapear e aprimorar as redes de comunicação, desenvolver sistemas que apoiem a comunicação; fortalecer as mídias da UnB; implementar a UnBTV em sinal aberto e a Rádio UnB; implementar a intranet e padronizar o uso da marca UnB nos sites e documentos institucionais. No documento, não consta um cronograma ou mais detalhes sobre essa política de comunicação e informação integradas (UNIVERSIDADE DE BRASÍLIA, 2015b).

No nível tático, S2 e D4 avaliam que é preciso dimensionar os recursos humanos e equipamentos e estabelecer diretrizes das pautas. S2 identifica como maior problema nesse nível a falta de discussão de pautas, prevalecendo o personalismo ou atendimento a interesses localizados ou de pessoas próximas. Já no operacional, S2 e D4 percebem a necessidade de se administrar as equipes de forma a alcançar qualidade e produtividade. Para S2, atualmente verifica-se a duplicação de esforços dos setores de comunicação e uma ausência na cobertura do que é mais importante para a UnB.

Tais análises se coadunam com a percepção de Kunsch (2003) de que é preciso ir além de ações isoladas de comunicação, centradas no planejamento tático, desvinculadas da 
análise do ambiente e das necessidades do público, de forma estrategicamente pensada. Assim, a autora avalia que é fundamental definir uma política global de comunicação, pois é ela que direcionará todos os processos comunicacionais da organização.

Nessa mesma perspectiva, S1 considera que o planejamento estratégico é a diretriz mais sólida que a organização pode ter para tomada de decisões. S1 avalia que é necessário ouvir as áreas de comunicação e ter a chancela da administração superior, para que esse planejamento seja o mais perene possível. G3 considera que é estratégico a comunicação estar próxima à Reitoria.

Genelot (2001) ratifica que o planejamento estratégico de comunicação agrega valores, integra as pessoas e produz mediações das organizações com seus públicos. Para que a comunicação organizacional torne-se, de fato, uma ferramenta estratégica, o autor recomenda a criação de canais de participação dos envolvidos. Kunsch (2003) acrescenta a necessidade de se estabelecer uma cultura de planejamento do pensamento estratégico, capaz de direcionar as atividades da organização para o alcance dos resultados. Ainda segundo a autora, é preciso que a área de comunicação esteja subordinada à cúpula diretiva, para que participe da gestão estratégica, e que seja estimulado o envolvimento das pessoas no processo de formulação do planejamento estratégico. Duarte e Monteiro (2009) defendem a criação de uma consciência comunicativa, com estímulo à cooperação.

D1 aborda o planejamento como uma etapa essencial em todo o processo de gestão. Mas ressalva que a separação em níveis - estratégico, tático e operacional - é mais difícil em uma organização complexa, como a UnB.

A seguir será transcrita uma extensa declaração desse participante (D1), pela relevância do conteúdo e pelo fato de o entrevistado ser uma referência na área de planejamento em comunicação: 


\begin{abstract}
"[...] uma instituição do porte da UnB é um mundo de diversidade. Praticamente todas as áreas do conhecimento estão aqui, com demandas específicas, mas, ao mesmo tempo, com a necessidade, imposta pela sociedade, de se integrarem mais ou terem mais atividades que sejam mais interdisciplinares, projetos que conectem várias visões e experiências, para o próprio bem da sociedade. [...] A UnB, desde a sua fundação, já nasceu com essa perspectiva de ir além dos muros, de fazer a diferença na sociedade. Está lá no seu projeto original. Então, eu imagino que em uma universidade com essas características e com toda essa diversidade, é sim, em termos, muito difícil trabalhar um plano estratégico que seja unificador e, ao mesmo tempo, integrador. Mas é um esforço que precisa ser buscado, precisa ser trabalhado. Claro que as diferentes reitorias, os tempos de mandato e as estruturas são sempre uma complicação nesses processos" (D1).
\end{abstract}

Para o referido entrevistado, o planejamento estratégico em uma universidade é praticamente inconcebível se ficar restrito apenas ao nível da Reitoria e dos decanatos e não envolver todas as unidades. Nesse sentido, conforme D1, os planos tático e operacional precisam estar alinhados com o planejamento estratégico. Essa visão é compartilhada por D3, para quem essa estratégia maior da comunicação da UnB ainda não foi construída.

As análises apresentadas por D1 estão em consonância com as investigações de diversos autores relacionados nesta pesquisa (ARAÚJO, 1996; BODINI, 1998; CUNHA, 1995; COSTÁBILE, 2007; ESTRADA, 2000; TOUSIGNANT, 1990), quanto aos desafios em se estabelecer um planejamento estratégico nas organizações universitárias. Assim como D1, Araújo (1996) identifica a falta de uma visão compartilhada da organização universitária e de percepção da importância de se institucionalizar o planejamento. Estrada (2000) ratifica que falta uma cultura de planejamento nas universidades e que há um descompasso nos mandatos de reitor e diretores.

D1 afirma não saber se a UnB tem um plano de comunicação, mas acredita que há uma tendência das outras áreas da universidade de achar que comunicação é divulgação, quando, na verdade, trata-se de apenas uma das etapas do processo.

De forma mais abrangente, G1 identifica que a maior dificuldade de planejamento na UnB, inclusive na área de comunicação, é a falta de garantia de recursos, o que pode inviabilizar uma maior versatilidade perante os desafios. G2 reforça esse ponto de vista, ao 
afirmar que na UnB é difícil executar o que se planeja, especialmente nos setores de comunicação. Já S1 considera que o maior problema da UnB é a falta de planejamento: “às vezes, o problema não é a falta dinheiro, é a falta de visão de longo prazo, visão estratégica".

$\mathrm{Na}$ avaliação de G4, para se alcançar um planejamento institucional na área de comunicação na UnB, é preciso buscar o que une as pessoas nesse planejamento e execução de ações. Para G4, as divergências são constitutivas no ambiente organizacional da UnB, mas é preciso estabelecer "pontes", estimulando cooperações que levem ao aprimoramento das ações desenvolvidas. Essa percepção vai ao encontro da análise de Araújo (1996), de que nas organizações universitárias o processo decisório é mais dependente de compromissos negociados. Na visão abrangente de Habermas (1989), todas as relações sociais são resultado de negociações, em que se busca o consenso, baseado no melhor argumento.

G3 avalia que o planejamento estratégico em comunicação possibilita otimizar os recursos, estabelecer metas e avaliar se as ações atingiram os objetivos propostos. Para S2, falta avaliação na UnB, de forma sistemática, relacionada com resultados. Já D1 entende que a avaliação decorre da pressão de comprovar, diariamente, a importância de uma gestão coerente do processo comunicacional.

Oliveira e Paula (2007, p. 49-50) explicam que o monitoramento permite identificar e avaliar "expectativas e demandas dos atores sociais e a influência que exercem na sua atuação". Segundo as autoras, o monitoramento refere-se à "contribuição da comunicação para o alcance dos objetivos organizacionais".

Quanto à técnica observação participante, foi possível perceber, na atuação cotidiana deste pesquisador na comunicação no âmbito da UnBTV, que falta um planejamento integrado de comunicação, uma vez que não são realizadas reuniões ou planejadas pautas conjuntas com a Secom. 
No próximo item será investigada a comunicação organizacional integrada, mais especificamente no âmbito da UnB.

\subsubsection{Comunicação Organizacional Integrada}

Nesta categoria serão analisados dois aspectos: a importância da integração dos setores e as mudanças que os sujeitos da pesquisa consideram necessárias para o estabelecimento dessa integração. Para tanto, a categoria foi subdividida em duas variáveis: Importância e Perspectivas. A primeira emergiu destes questionamentos: 1) O que você entende por comunicação organizacional integrada? e 2) Você considera importante integrar os setores da comunicação da UnB? Já a variável Perspectivas foi criada para tratar os desdobramentos das seguintes perguntas: 1) Quais mudanças você considera que são importantes para que ocorra a integração da comunicação da UnB?; 2) Quais são os desafios para a integração da comunicação da UnB?; 3) Que tipo de ação contribuiria para a integração dos setores de comunicação da UnB? e 4) Você avalia que a integração dos setores de comunicação da UnB possibilitaria uma maior sinergia com os campi e a expansão do setor de comunicação destes?

\subsubsection{Importância da comunicação organizacional integrada}

O Quadro 13 apresenta a percepção dos entrevistados em relação à importância da integração dos setores de comunicação da UnB. 
Quadro 13 - Importância da comunicação integrada na UnB

\begin{tabular}{|l|l|}
\hline Entrevistados & \\
\hline $\mathbf{G 1}$ & $\begin{array}{l}\text { - Evitaria a duplicação de esforços; } \\
\text { - Possibilitaria a unidade do discurso. }\end{array}$ \\
\hline $\mathbf{G 2}$ & $\begin{array}{l}\text { - Evitaria gastos; } \\
\text { - Otimizaria os recursos; } \\
\text { - Evitaria a duplicação de esforços. }\end{array}$ \\
\hline $\mathbf{G 3}$ & - Otimizaria os recursos humanos, materiais e tecnológicos. \\
\hline $\mathbf{G 4}$ & $\begin{array}{l}\text { - Possibilitaria um fluxo planejado de ações; } \\
\text { - Permitiria comunicar melhor. }\end{array}$ \\
\hline D1 & $\begin{array}{l}\text { - Desenvolveria uma perspectiva integrada com a identidade UnB; } \\
\text { - Permitiria a unidade do discurso. }\end{array}$ \\
\hline D2 & - Possibilitaria melhor comunicação com a sociedade, a partir da unidade do discurso. \\
\hline D3 & $\begin{array}{l}\text { - Otimizaria a força de trabalho e a aplicação de recursos; } \\
\text { - Evitaria a duplicação de esforços. }\end{array}$ \\
\hline D4 & - Otimizaria recursos humanos e equipamentos. \\
\hline S1 & - Aumentaria a produtividade, com maior abrangência das coberturas. \\
\hline S2 & - Evitaria a duplicação de esforços. \\
\hline E1 & - Otimizaria os recursos. \\
\hline
\end{tabular}

Fonte: Elaboração do autor.

Conforme se verifica no Quadro 13, os participantes consideram importante a integração dos setores de comunicação da UnB, estratégia descrita no capítulo $\mathrm{V}$, que consta do Plano de Desenvolvimento Institucional (PDI/UnB) 2014-2017 para o aprimoramento da comunicação institucional (UNIVERSIDADE DE BRASÍLIA, 2015b).

De forma conceitual, D1 afirma que a comunicação organizacional integrada tem sido pensada como a integração das comunicações interna, institucional, mercadológica e administrativa. Tal conceito é explorado por diversos autores, citados na presente pesquisa (BUENO, 2002; KUNSCH, 2003; NEVES, 2000; TORQUATO DO REGO, 2015). A comunicação é percebida por esses teóricos como um macrossistema, ao qual é preciso integrar os microssistemas, visando manter a unidade do discurso institucional e, assim, fortalecer a identidade da organização.

Nesse sentido, Torquato do Rego (2015) aponta que a coordenação centralizada permite preservar uma linguagem homogênea e integrada. Já Bueno (2002) avalia que a 
comunicação integrada possibilita agregar valor à marca da organização junto aos públicos específicos ou à sociedade em geral

D1 ressalva que a comunicação também pode ser entendida como constitutiva das organizações, as quais surgem, desenvolvem-se e se autoconfiguram a partir da comunicação, independentemente de ali haver uma gestão coordenada. Mas o docente (D1) acrescenta que, na perspectiva da gestão da comunicação, é preciso analisar todas as dimensões. Para S2, a comunicação integrada é a unificação de esforços para o alcance de objetivos institucionais, agregando as ações de cada unidade nesse sentido.

Em igual perspectiva, Kunsch (2003) afirma que o sistema integrado permite aos vários setores de comunicação coordenarem esforços, visando ao alcance dos objetivos gerais, respeitados os objetivos específicos de cada unidade. No âmbito das IES, Kunsch (1992) destaca que, além de evitar a duplicidade de esforços e gastos desnecessários, a comunicação integrada incentiva trabalhos inter e multidisciplinares.

Os sujeitos de pesquisa avaliam, de forma majoritária, que integração dos setores de comunicação, possibilitaria a otimização dos recursos, evitaria a duplicação de esforços e permitiria a unidade do discurso.

Nessa perspectiva, G2 pondera:

"[...] a gente precisa se organizar e se integrar para otimizar custos, otimizar trabalho. [...] Quando você está em conjunto, você consegue fortalecer muito mais os seus objetivos, as suas brigas e as suas conquistas. [...] Se você agregar uma comunicação à outra existente, você vai juntar um grupo de pessoas e de propostas para conseguir, em conjunto, mais orçamento, mais pessoas, otimizar custos. Enfim, a gente pode ter uma série de vantagens com essa organização e esse planejamento" (G2).

Esse(a) gestor(a) considera importante a integração física dos três setores - Rádio, Secom e UnBTV -, pois contribuiria para diminuir os gastos. Já S1 considera que a integração não significa juntar espaços, mas sim, aumentar o diálogo entre as áreas. D3 avalia que a construção de um prédio deve ser uma meta a longo prazo, pois a UnB não dispõe de 
recursos para esse investimento. Além disso, esse(a) docente aponta que seria necessário levar em conta também as especificações técnicas para a construção de estúdios de TV e de Rádio, o que demanda tempo. Mas D3 considera que a integração independe de um prédio em comum de atuação. G3 e D4 acreditam que a integração permitiria compartilhar os profissionais, de acordo com a necessidade dos setores.

A integração é analisada por parte considerável dos entrevistados como uma forma de evitar a duplicação de esforços, na medida em que não se teriam vários profissionais realizando a mesma cobertura jornalística de atividades e eventos.

D3 relata um problema recorrente na comunicação da UnB, devido à falta de integração e coordenação de esforços entre a Secom e a UnBTV:

\begin{abstract}
“[...] às vezes, tenho em um único evento quatro profissionais de comunicação, quando eu poderia ter dois e outros cuidando de outras coisas tão importantes. A comunicação também priorizaria que atividades dar mais atenção. Todos ficam esperando que alguém faça isso, porque se você não tem essa coordenação geral, a tendência de cada unidade é se reportar ao seu gestor imediato e agir dentro do seu espaço e isoladamente. E isso já está provado que já não combina mais com os tempos de hoje" (D3).
\end{abstract}

G2 e D3 destacam que, cada vez mais, os profissionais em comunicação precisam ser multitarefa e multimídia. Assim, G2 exemplifica que um repórter poderia fazer imagens, com equipamentos mais leves, para TV e escrever reportagens que poderiam ser divulgadas na Rádio e no Portal UnB. Nesse sentido, S1 cita que está sendo implantado um sistema de fluxo de pautas entre a Secom e a UnBTV. D3 considera fundamental a convergência tecnológica na comunicação da UnB e avalia que o espaço para essa convergência é o Portal.

Para G4, é preciso que as unidades da UnB trabalhem, ao menos, aproximadas, de um lado com melhor fluxo de informações e comunicação entre a Secom e a UnBTV e, de outro lado, com a Editora UnB, a Biblioteca da UnB (BCE), FAC e área de TI. Nesse cenário, (G4) exemplifica que seria possível compartilhar vídeos do canal Youtube da UnBTV na Biblioteca, como referência; na editora, quando se tratar de lançamento de livro e no Portal UnB. G4 avalia que a comunicação da UnB precisa ser multiplataforma, multilíngua e 
multimodal, para alcançar um público diversificado. Tais terminologias remetem ao conceito de transmídia. Segundo Gabriel (2012), trata-se do uso integrado das mídias, ultrapassando os limites de um único meio. Dessa forma, a informação é fragmentada com base nas possibilidades de cada canal.

Jenkins (2009), pioneiro no estudo desse tema, explica que a convergência é o fluxo de informações entre vários suportes midiáticos, os quais mantêm suas especificidades. Conforme o autor, a convergência não promove uma substituição dos tradicionais meios de comunicação, mas a introdução de novas tecnologias.

Torquato do Rego (2015, p. 17) avalia que a comunicação precisa ser vista como "uma ação integrada de meios, formas, recursos, canais e intenções”. Segundo o autor,

É preciso descobrir como criar uma linguagem mais adequada e rápida dentro da tecnologia que permeia o sistema de comunicação e informação das organizações; como trabalhar melhor as redes, utilizando referências linguísticas apropriadas; como ampliar as possibilidades da comunicação digital, que hoje reúne, em uma só mensagem, texto, imagem, vídeo e áudio (o chamado hipertexto) (TORQUATO DO REGO, 2015, p. 17).

Outra vantagem da integração, apontada por gestores e docentes, é quanto à unidade do discurso. Para D1, o discurso institucional e as ações de comunicação relativas aos serviços e produtos de uma universidade têm que estar alinhadas a um mesmo discurso, ou ao menos a uma linha coerente de discurso, para que a instituição comece, a partir daí, a forjar a sua própria identidade.

D2 avalia que quanto mais as áreas de comunicação da UnB estiverem integradas, melhor conseguirão dialogar publicamente, o que reforçará a imagem da UnB perante a sociedade. D2 explica que não se trata de algo imposto, em que todos seguirão o discurso da Reitoria, mas sim, de um espaço de liberdade, no qual as pessoas dialoguem publicamente, no sentido de reforçar a grandeza da UnB. 
Conforme Kunsch (2003, p. 164), é de reponsabilidade direta da comunicação institucional a "construção e formação de uma imagem e identidade corporativas fortes e positivas de uma organização”.

Castro (2013) ressalva que a tarefa de produção da imagem em uma instituição polissêmica como uma universidade, caracterizada pela "porosidade comunicativa", não se restringe à área de comunicação institucional. Para a autora,

(...) a tarefa de construção da imagem institucional que se projeta socialmente é responsabilidade a ser compartilhada por todos, na medida em que essa imagem é afetada pela ação de cada um, ao mesmo tempo em que atinge toda a Instituição na capacidade de ser reconhecida e de obter apoio e legitimidade para suas ações e pretensões (CASTRO, 2013).

No próximo item será aprofundada a análise a respeito das mudanças e desafios percebidos pelos participantes para a efetivação de uma comunicação integrada na UnB.

\subsubsection{Perspectivas da comunicação organizacional integrada}

O Quadro 14 apresenta a percepção dos entrevistados em relação às perspectivas da integração dos setores de comunicação da UnB, o que envolve as principais mudanças e os desafios a enfrentar. 
Quadro 14 - Perspectivas da comunicação integrada na UnB

\begin{tabular}{|c|c|}
\hline Entrevistados & Perspectivas: mudanças e desafios \\
\hline G1 & $\begin{array}{l}\text { - Os profissionais da área devem apresentar uma proposta convincente; } \\
\text { - Escolher um modelo que integre sem criar maior burocratização. }\end{array}$ \\
\hline G2 & $\begin{array}{l}\text { - Depende de determinação e de vontade política; } \\
\text { - Convencer as pessoas de que a integração é necessária, superando o comodismo; } \\
\text { - Sensibilizar a administração superior; } \\
\text { - Integrar os campi da UnB. }\end{array}$ \\
\hline G3 & $\begin{array}{l}\text { - Definir se outros setores serão integrados à comunicação; } \\
\text { - Romper a fragmentação e pensar em conjunto; } \\
\text { - Criar um orçamento para a comunicação; } \\
\text { - Integrar os campi da UnB. }\end{array}$ \\
\hline G4 & $\begin{array}{l}\text { - É preciso que as pessoas tenham vontade de desenvolver atividades juntas; } \\
\text { - Romper a fragmentação, mas sem pressa; } \\
\text { - Envolver outros setores na comunicação; } \\
\text { - Capacitar os profissionais e distribuí-los melhor. }\end{array}$ \\
\hline D1 & $\begin{array}{l}\text { - Depende da vontade política dos envolvidos diretamente com a área; } \\
\text { - Estabelecer diálogo entre as lideranças dos setores; } \\
\text { - Agregar outras áreas; } \\
\text { - Convencer que a integração é necessária; } \\
\text { - Integrar os campi da UnB. }\end{array}$ \\
\hline D2 & $\begin{array}{l}\text { - Não seria mudança, mas aperfeiçoamento, com mais investimentos; } \\
\text { - Pensar em rede; } \\
\text { - Integrar os campi da UnB. }\end{array}$ \\
\hline D3 & $\begin{array}{l}\text { - Estabelecer uma diretriz comum, com o envolvimento da alta administração e dos } \\
\text { profissionais da área; } \\
\text { - Convencer a Reitoria de que a integração é necessária; } \\
\text { - Ter um prédio para a área - a longo prazo. }\end{array}$ \\
\hline D4 & $\begin{array}{l}\text { - Ter um setor da UnB que reúna as áreas de comunicação; } \\
\text { - Obter mais recursos humanos, instalações físicas e equipamentos. }\end{array}$ \\
\hline S1 & $\begin{array}{l}\text { - Aprender a trabalhar de forma integrada; } \\
\text { - Convencer que a integração é necessária; } \\
\text { - Superar as limitações de infraestrutura e recursos. }\end{array}$ \\
\hline S2 & $\begin{array}{l}\text { - Envolver a administração superior e os profissionais da área; } \\
\text { - Convencer que a integração é necessária; } \\
\text { - Integrar os campi da UnB. }\end{array}$ \\
\hline E1 & $\begin{array}{l}\text { - É preciso que as pessoas da área tenham vontade de trabalhar juntas; } \\
\text { - Convencer a administração superior que todos os setores são igualmente importantes. }\end{array}$ \\
\hline
\end{tabular}

Fonte: Elaboração do autor.

Conforme é possível constatar pelo Quadro 14, na perspectiva de integração dos setores de comunicação, os participantes da pesquisa destacam a necessidade de envolvimento da alta administração e das pessoas da área, o convencimento de que a integração é necessária, o envolvimento de outros setores da UnB à comunicação e a integração dos campi. Os entrevistados, de forma majoritária, avaliam que é preciso convencer as pessoas e a cúpula 
diretiva de que a integração é necessária - o que está relacionado à vontade dos comunicadores de trabalhar em conjunto e à vontade política da administração superior.

Para G2, as pessoas que trabalham com a comunicação da UnB precisam pensar mais na instituição do que em seus próprios interesses. Ou seja, todos os envolvidos precisam querer trabalhar juntos. Além disso, $(\mathrm{G} 2)$ ratifica que é preciso uma determinação política para que a integração se efetive:

\begin{abstract}
"Todos precisam aceitar, mas mais importante do que isso é ter uma determinação e uma vontade política. Porque não adianta a vontade individual. Se for melhor para a instituição, tem que ter determinação política de executar isso, porque, se não tiver, não acontece. Vai ficar eu cuidando da minha TV, um outro cuidando da sua Rádio, porque é tudo na primeira pessoa. É a minha TV, é a minha Rádio. E não é assim que as coisas funcionam no serviço público. Isso aqui é uma instituição pública, eu não sou proprietário de nada. As pessoas primeiro têm que perder essa noção ou essa sensação de propriedade" (G2).
\end{abstract}

D1 também considera que é preciso contar com o apoio da alta administração, a qual deve atrair os envolvidos para uma conversa, na tentativa de pensar em saídas integradas. Se for muito difícil, D1 avalia que um caminho seria a unificação dos setores. Segundo D1, a cultura da universidade é que tudo seja discutido à exaustão.

Essa análise alinha-se com as ideias de Araújo (1996), para quem a natureza das universidades exige que os variados interesses se apresentem, no sentido de estabelecer um pacto que confira legitimidade e condições de execução às decisões. "Isso pressupõe negociação sobre fins e meios, distribuição do poder e rejeição de racionalidades únicas e absolutas no sistema organizacional" (ARAÚJO, 1996, p. 83).

D3 sintetiza: integração é convergência; assim, todos precisam entender que é preciso trabalhar em conjunto. Para D3, se as pessoas ficarem arraigadas em suas funções e tarefas, não haverá integração. S1 avalia que é necessária uma mudança cultural: “aprender a trabalhar de outra forma, olhando o que o outro está fazendo". Igualmente, G4 defende que o principal é a comunicação dentro da comunicação, ou seja, fazer com que as pessoas se conheçam e criem planos conjuntos. 
Para S2, a cultura do trabalho integrado precisa fazer parte do dia a dia dos comunicadores. Já para E1, falta vontade das pessoas de trabalharem juntas, pois "parece haver mais competição do que integração".

D3 avalia que a integração depende do estabelecimento de uma diretriz comum, um plano estratégico, que deve orientar as ações dos setores. Para D3, essa diretriz não existe porque cada setor tenta cumprir o seu papel dentro de suas especificidades e não como uma estratégia construída pela UnB. Kunsch (2003, p. 247) explica que "o plano estratégico de comunicação organizacional tem como proposta básica estabelecer as grandes diretrizes, orientações e estratégias para a prática da comunicação integrada nas organizações”. Mas, segundo a autora, para o planejamento estratégico de comunicação organizacional atingir seus objetivos é preciso que os colaboradores conheçam o plano e participem do processo. Nesse sentido, faz-se necessário propagar o plano, colocá-lo em prática, controlar as etapas e avaliar os resultados.

$\mathrm{Na}$ avaliação de D1, a simples proposta de fusão das áreas pode parecer perda de poder e de recursos para alguns. Assim, (D1) recomenda que sejam realizadas reuniões com a presença da alta administração da UnB. S1 sugere que as reuniões ocorram quinzenalmente. S2, por sua vez, considera fundamental o envolvimento de outros departamentos, para saber o que é possível alcançar com a integração: "o quanto cada unidade pode ganhar, o quanto a universidade pode ganhar”.

G2 afirma que é preciso convencer as pessoas a saírem da zona de conforto e aceitarem os desafios de uma comunicação integrada. Além disso, $(\mathrm{G} 2)$ avalia que os gestores também precisam perceber a importância da comunicação integrada. G1, por outro lado, afirma que os profissionais da área de comunicação devem apresentar à administração superior uma proposta que seja convincente. 
Kunsch (2003) confirma que a elaboração de um plano estratégico de comunicação deve ser pensada a partir da tomada de decisão das autoridades da organização, após ouvir especialistas no assunto, profissionais de comunicação, assessorias e agências de comunicação que prestam serviços externos.

Nessa perspectiva, os integrantes dos setores de comunicação da UnB encaminharam ao gabinete da Vice-Reitoria, em junho de 2014, uma proposta de comunicação integrada, em atendimento à Resolução n. ${ }^{\circ} 04$ da Vice-Reitoria (ANEXO A). Essa proposta (ANEXO G) prevê a criação de uma superintendência de comunicação, que agregaria a Secom, a Rádio UnB e a UnBTV.

Esse documento proposto, resultado de discussões com os setores de comunicação, não inclui outras áreas da UnB, como a Editora UnB, a Faculdade de Ciência da Informação (FCI) ou o Departamento de Ciência da Computação (CIC), que podem ser reunidos em uma “segunda etapa" (ANEXO C).

Para os entrevistados G4 e D1, um dos desafios para a integração é justamente agregar competências de outras áreas. A gestão da comunicação é pensada, assim, de forma colegiada com outras unidades que têm uma interface com a área de comunicação. D1 explica que a comunicação pode ser vista como um ente comunicativo ao qual, de alguma forma, várias áreas têm interferência no processo.

Na avaliação de D1, a integração deve incluir a área de Tecnologia da Informação (TI), pois cada vez mais as organizações e os profissionais dependem da área de informática, inclusive para experimentar novas possibilidades e espaços de interação. G4 prefere pensar em sistemas aproximados, com maior compartilhamento de informações entre as áreas de comunicação e outras unidades da UnB. Para G4, é importante e necessário abrir canais de integração com a universidade como um todo. 
Nessa mesma perspectiva, D2 compreende a universidade como uma rede, de departamentos e de professores trabalhando em diversas áreas do conhecimento. Assim, (D2) avalia que é preciso pensar em rede, somando outras instâncias, citando como exemplo o site da FAC/UnB.

Essa compreensão de comunicação em rede encontra apoio nas ideias de vários teóricos modernos. A partir da concepção de que uma organização é um sistema vivo e aberto, conectado por um fluxo de informações entre as pessoas que ocupam diferentes posições distintos papéis, Goldhaber (1991) define a comunicação organizacional como sendo o fluxo de mensagens processadas em uma rede de relações interdependentes. Dessa forma, coexistem subsistemas, os quais afetam e são afetados mutuamente, e o sistema como um todo. Duck (2005) percebe a organização como um móbile, formada por uma rede de interconexões. Nassar, Furnaletto e Figueiredo (2009) reforçam que a organização é hoje um nó de uma grande rede. Capra (2005) vai além e afirma que a rede é um dos padrões mais básicos de todos os sistemas vivos, uma vez que em todos os níveis de vida há interligações em forma de rede. Para Castells (1999), o que move a inovação na atividade humana é o nãoestruturado. Segundo esse autor, um sistema com base em redes caracteriza-se por ser dinâmico e aberto à inovação.

G4 concorda que é preciso trabalhar em rede, possibilitando que as unidades também tenham condições de estabelecer instrumentos de comunicação. Para G4, é importante saber fazer a interface, sem uma comunicação diluída, mas também sem achar que o processo de comunicação é monopólio dos profissionais de comunicação da universidade.

Nesse sentido, Castro (2013) afirma que é preciso assumir que a tarefa de comunicar não é apenas dos profissionais desse ofício, mas sim uma responsabilidade compartilhada por todos. Para a autora, transformar cada dirigente e servidor em fontes confiáveis, precisas e ágeis é um desafio contínuo. 
G4 aponta como um desafio romper a fragmentação, mas de forma sustentável, sem açodamento. G3 concorda, ao afirmar que é preciso "romper as caixinhas e enxergar o todo". Como exemplo dessa fragmentação, esse(a) gestor(a) cita os sites das diversas unidades da UnB, os quais não apresentam unidade visual, nem padronização de conteúdo, de formato ou de linguagem.

Outro aspecto desafiador para a integração diz respeito à necessidade de maior sinergia com os campi da UnB. D1 explica que os campi começam a se estruturar fisicamente, ao mesmo tempo em vão criando a sua própria identidade, a qual precisaria ser desenvolvida em uma perspectiva integrada com a identidade UnB. Segundo D1, parece haver um sentimento de que a UnB é o campus Darcy e os campi são satélites, ou porque têm menos recursos ou porque estão um pouco abandonados. D1 afirma que o esforço deve ser de integrar os campi e que esse é um grande desafio, pois a estrutura da Secom está centrada no campus Darcy, dificultando o acompanhamento. Uma alternativa, segundo esse(a) docente, seria trabalhar em rede, contando com a ajuda no processo comunicacional de pessoas que atuam nesses campi.

Nessa perspectiva, S2 avalia que a integração dos campi poderia ser reforçada com o desenvolvimento ou fortalecimento de emprego das novas tecnologias da comunicação, por uma questão de redução de custos e dinamismo. A ideia, segundo S2, seria estimular as pessoas a participar da comunicação.

G2 destaca que a UnBTV dispõe de um "posto avançado" em Planaltina e que o ideal seria a TV contar com filiais em todos os campi, pois a concentração de esforços no Plano Piloto faz com que o setor fique alheio às produções da UnB em outras localidades. D3 destaca que, com a contratação de mais profissionais, será possível melhorar a cobertura jornalística do que ocorre nos campi da UnB. 
A seguir serão analisadas experiências de outras IES públicas que têm se empenhado em equalizar essas questões relacionadas à gestão integrada de comunicação.

\subsubsection{Comunicação Integrada em outras IES}

Nesta categoria, busca-se relacionar experiências de gestão integrada no âmbito da comunicação de universidades públicas brasileiras com o processo de construção de uma política de comunicação integrada na UnB. Será analisada apenas uma variável: o conhecimento dos entrevistados a respeito dessas experiências em outras IES públicas.

Para a elaboração da proposta de uma política de comunicação integrada, a comissão instituída pela VRT/UnB, por meio da Resolução n. ${ }^{\circ}$ 04/2013 (ANEXO A), buscou experiências bem sucedidas de integração da comunicação em outras IES. Nessas entidades, o modelo adotado foi a criação de uma superintendência, a qual agregaria os setores de comunicação. A proposta final da comissão baseou-se na estrutura da Comunica Superintendência de Comunicação da UFRN (UNIVERSIDADE FEDERAL DO RIO GRANDE DO NORTE, 2015).

Na revisão de literatura deste estudo, foram analisadas, além da Comunica/UFRN, os seguintes modelos: a Superintendência de Comunicação Social da Universidade de São Paulo (SCS/USP), a Superintendência de Comunicação Social da Universidade Federal Fluminense (SCS/UFF), a Superintendência de Cultura e Comunicação da Universidade Federal do Espírito Santo (Supecc/UFES) e a Superintendência de Comunicação Social da Universidade Federal do Piauí (SCS/UFPI).

O Quadro 15 relaciona, por ordem de citação, o conhecimento dos participantes acerca dessas superintendências de comunicação ou outras experiências de comunicação organizacional integrada em IES brasileiras. Vale frisar que alguns dos entrevistados integraram ou colaboraram nos trabalhos da comissão instituída pela Resolução n. ${ }^{\circ}$ 04/2013 da VRT/UnB (ANEXO A). 
Quadro 15 - Experiências de comunicação integrada em outras IES públicas

\begin{tabular}{|c|l|}
\hline Entrevistado & \multicolumn{1}{|c|}{ Modelo de comunicação integrada em IES } \\
\hline G1 & Desconhece. \\
\hline G2 & Comunica/UFRN, SCS/UFF, SCS/USP, SCS/UFPI, Supecc/UFES e CCS/UFScar. \\
\hline G3 & Supecc/UFES, SCS/UFPI, Comunica/UFRN e SCS/USP. \\
\hline G4 & Comunica/UFRN, Supecc/UFES e SCS/UFPI. \\
\hline D1 & SCS/USP e CECOM/UFG. \\
\hline D2 & Desconhece. \\
\hline D3 & Comunica/UFRN e SCS/USP. \\
\hline D4 & Desconhece. \\
\hline S1 & SCS/UFF e SCS/USP. \\
\hline S2 & Comunica/UFRN, SCS/UFF e SCS/USP. \\
\hline E1 & Desconhece. \\
\hline
\end{tabular}

Fonte: Elaboração do autor.

Para G2, a criação de um órgão que centralize a comunicação é uma tendência dentro das IES. Segundo G2, algumas dessas superintendências agregaram outras áreas e cita como exemplo a Supecc/UFES, que integrou a Secretaria de Cultura. Conforme informações do portal da UFES, a Supecc está dividida em duas secretarias: a de Cultura e a de Comunicação, que contam com núcleos. Compõem a Secretaria de Cultura a Editora UFES (EdUFES), o Coral da UFES e a Coordenação de Produção e Programação. A secretaria gerencia, ainda, os espaços culturais: Galeria Espaço Universitário, Cine Metrópolis, Teatro Universitário e Livraria da UFES (UNIVERSIDADE FEDERAL DO ESPÍRITO SANTO, 2015a).

G3 avalia que uma superintendência de comunicação da UnB poderia seguir o exemplo da Supecc e agregar a área de cultura, pois contribuiria para a difusão cultural e o gerenciamento dos espaços culturais da UnB: galeria, teatro, cinema e editora.

Além do modelo de superintendência, G2 cita o formato da Coordenadoria de Comunicação Social (CCS) da UFScar. Segundo informações do portal da UFScar, a CCS conta com divisões por área de atuação, como Jornalismo, Artes e Tecnologia da Informação. Ao lado dessa estrutura, porém, não coordenada pela mesma direção, existe a Rádio UFSCar e 
a Assessoria de Comunicação da Reitoria (UNIVERSIDADE FEDERAL DE SÃO CARLOS, 2015).

Segundo D1, na maior parte das IES as unidades de comunicação encontram-se isoladas, sem integração do discurso e dos trabalhos. D1 ressalta o esforço da USP de envolver estudantes e professores nos vários instrumentos de comunicação daquela universidade. E (D1) cita o modelo da Universidade Federal de Goiás (UFG): o CECOM, Centro de Comunicação da UFG, que faz parte das ações a serem implementadas na área de comunicação daquela universidade. De acordo com o Plano de Gestão 2014-2017 da UFG, o CECOM será responsável pela “formulação integrada da política de comunicação da Universidade, com participação das suas diversas unidades e órgãos" (UNIVERSIDADE FEDERAL DE GOIÁS, 2015, p. 42).

D3 avalia que quanto mais áreas de comunicação uma IES tem, mais necessidade surge de articulação. Para D3, as superintendências de comunicação precisam contar com uma fundação de apoio, para transformar as ações de comunicação em projetos. Como exemplo, D3 cita a Comunica - Superintendência de Comunicação da UFRN, a qual conta com um núcleo para captação de recursos, a Coordenadoria de Promoção Institucional (UNIVERSIDADE FEDERAL DO RIO GRANDE DO NORTE, 2015).

A Comunica/UFRN agrega em sua estrutura três setores de comunicação: Agência de Comunicação, Rádio Universitária FM e TV Universitária (UNIVERSIDADE FEDERAL DO RIO GRANDE DO NORTE, 2014).

G2 e S2 também destacam a Comunica como um modelo a ser seguido. S2 ressalta que a criação dessa superintendência contou com etapas de pré-implantação e pósimplantação, para discutir as possibilidades de uma comunicação integrada.

Entretanto, apesar de ser considerada uma referência pelos entrevistados, a Comunica vem enfrentando graves dificuldades, conforme carta aberta dos servidores da 
superintendência encaminhada à Reitoria da UFRN (SINTEST-RN, 2015). A seguir será apresentado o teor desse documento, tendo em vista que a Comunica serviu de modelo à Proposta de Política de Comunicação para a UnB (ANEXO G). A carta relata vários problemas da gestão desenvolvida na Comunica nos últimos quatro anos (2011-2015), entre os quais: problemas estruturais da TVU e da Rádio; censura da gestão da Comunica sobre o próprio jornalismo; perseguição a servidores; suspensão de projetos em andamento da gestão anterior; suspensão do Jornal da UFRN, entre outras denúncias.

Os servidores da Comunica reivindicam, entre outros itens: a valorização do caráter público das emissoras de Rádio e TV da UFRN; a realização de audiências públicas para debater as programações das emissoras; a instalação de um conselho consultivo; a alteração do Regimento Interno (UNIVERSIDADE FEDERAL DO RIO GRANDE DO NORTE, 2015) para garantir espaços democráticos de diálogos na gestão; o desmembramento da diretoria de rádio e da $\mathrm{TV}$, devido à incompatibilidade das rotinas de produção; a criação de um conselho de gestão participativa com a representação de servidores da Comunica; a criação de comissões para definir a política editorial e os eixos da programação, além de avaliar a qualidade dos produtos; a criação da ouvidoria da Comunica e o estabelecimento de um processo democrático de consulta para a escolha dos gestores da superintendência.

Vale ressaltar que a Lei n. 11.652 (BRASIL, 2008) prevê a participação da sociedade civil no controle da aplicação dos princípios do sistema público de radiodifusão.

Os problemas de gestão relatados pelos servidores da Comunica/UFRN evidenciam as peculiaridades da universidade, cuja estrutura é complexa e diferente de outras organizações (ARAÚJO, 1996). Maiochi (1997, p. 280) afirma que as IES públicas utilizamse de "decisões políticas, negociações, barganhas, beneficiando o tomador de decisões, em termos individuais ou grupais". 
Ainda segundo o autor, o maior número e as mais significativas decisões são tomadas pela cúpula, sendo que a participação dos docentes e servidores é feita por representantes, sem grande significação. Para Maiochi (1997), a gerência participativa na tomada de decisões da universidade pública - envolvendo a comunidade acadêmica para consolidar a democracia - quase não ocorre, uma vez que as estruturas são rígidas, caracterizadas por mecanismos de centralização do poder.

A seguir será apresentada a última categoria deste estudo: o modelo proposto de superintendência de comunicação da UnB.

\subsubsection{Superintendência de Comunicação da UnB}

Neste item, será analisada a proposta de criação de uma superintendência de comunicação da UnB, no âmbito do modelo da comissão instituída pela Resolução n. ${ }^{\circ}$ 04/2013, da Vice-Reitoria da UnB. Para melhor tratamento dos dados, esta quinta e última categoria foi subdividida em duas variáveis: Avaliação e Perspectivas. A primeira emergiu de duas perguntas: 1) Você avalia que a criação de um órgão que articule as ações de comunicação no âmbito da UnB, como uma superintendência, pode, de fato, instituir uma política de comunicação integrada na universidade? e 2) Quais são as vantagens da criação de uma superintendência de comunicação na UnB? A segunda variável (Perspectivas) foi criada a partir de quatro questionamentos: 1) Quais as consequências que você identifica com a criação de uma superintendência que agregue os setores de comunicação da UnB?; 2) Quais etapas você considera que são importantes seguir para a implantação da superintendência?; 3) A criação de uma superintendência pode favorecer a um maior protagonismo dos servidores da UnB no planejamento das ações de comunicação da universidade? e 4) Você avalia que pode ser afetado de alguma forma com a criação de uma superintendência de comunicação da UnB? 


\subsubsection{Avaliação da proposta de Superintendência de Comunicação da UnB}

O Quadro 16 apresenta a avaliação dos participantes a respeito da criação e órgão que centralize a comunicação da UnB, como uma superintendência.

Quadro 16 - Avaliação do modelo de Superintendência de Comunicação da UnB

\begin{tabular}{|c|c|}
\hline Entrevistados & Avaliação \\
\hline G1 & O debate não está amadurecido nem na própria área de comunicação. \\
\hline G2 & Esse seria o caminho ideal para a integração dos setores. \\
\hline G3 & Pode levar à implantação de um macroplanejamento de comunicação. \\
\hline G4 & $\begin{array}{l}\text { Pode significar um canal para ações integradas dos setores, respeitando-se as } \\
\text { especificidades. }\end{array}$ \\
\hline D1 & Pode ser uma saída. É um modelo já testado em outras IES para integrar as áreas. \\
\hline D2 & Pode criar uma burocratização. É melhor trabalhar em rede, com o que já existe. \\
\hline D3 & É importante e necessária para integrar os setores de comunicação da UnB. \\
\hline D4 & Pode ser um caminho para instituir uma política de comunicação integrada. \\
\hline S1 & $\begin{array}{l}\text { A superintendência é a forma ideal para estabelecer um planejamento estratégico de } \\
\text { comunicação, respeitadas as diferenças de cada setor. }\end{array}$ \\
\hline S2 & Pode ser um caminho para instituir uma política de comunicação integrada. \\
\hline E1 & É necessária para se definir níveis de planejamento para a comunicação. \\
\hline
\end{tabular}

Fonte: Elaboração do autor.

Conforme é possível verificar pelo Quadro 16, a grande maioria dos participantes considera que a criação da superintendência é um caminho eficaz para a integração dos setores de comunicação da UnB.

G2 e D4 destacam que, com a superintendência, haveria uma estrutura administrativa única, mais forte e mais efetiva. Tal estrutura está prevista na proposta de criação da Superintendência de Comunicação da UnB, a qual teria em seu organograma uma secretaria. A Secretaria Administrativa seria responsável pelos serviços de apoio quanto à administração de pessoal, materiais, patrimônio, finanças e demais serviços. Em sua constituição, fariam parte o Setor de Gestão de Pessoas, Serviços e Patrimônio e o Setor de Documentação, Acervo e Memória (ANEXO G). 
Parte considerável dos sujeitos da pesquisa avalia que, com uma superintendência, seria possível criar espaço para a definição de um planejamento estratégico de comunicação da UnB. No sentido de implementar esse macro planejamento, a proposta da comissão instituída pela Resolução n. ${ }^{\circ}$ 04/2013, da VRT/UnB prevê o estabelecimento da Política de Comunicação Integrada da UnB (ANEXO G), com a articulação das ações comunicacionais para uma atuação orgânica, baseada em metas, objetivos, direcionamento estratégico, transparência, eficiência, efetividade e agilidade. Segundo o mesmo documento, a comunicação da UnB é estratégica e transversal às ações e atividades acadêmicas, voltada para atender aos princípios e diretrizes da instituição.

Na avaliação de D3, a criação da superintendência pode provocar uma sinergia entre os diferentes órgãos e criar um espaço para definir essa estratégia maior. Nessa mesma linha, S1 avalia que a superintendência garantiria um planejamento estratégico, assumindo as funções que a comunidade acadêmica espera da Secom.

\footnotetext{
"A Secom tem mais ou menos essa imagem da superintendência. Tudo é com a Secom. Então, talvez tire um pouco desse peso ou transfira para quem realmente é de direito. Se você tiver uma superintendência, você pode delimitar mais o que a comunicação da UnB faz" (S1).
}

Já para D1, a criação da superintendência possibilitaria integrar as áreas sob um mesmo comando, unificar o discurso e delimitar o foco de atuação. Esse(a) docente avalia que quando não há uma cultura na organização de trabalhar junto, pode ser melhor integrar em um único setor as diversas áreas.

\footnotetext{
"Se for criado um sistema de confiança e de relacionamento entre todos e que todos trabalhem para um mesmo objetivo, se estão trabalhando lá em Cingapura, ou no campus de Planaltina, ou no campus Darcy, isso não seria necessariamente um problema. Mas pode ser que, para que isso aconteça, para que haja essa percepção da importância de trabalhar juntos, pode ser que em um determinado momento a solução institucional seja criar uma superintendência, juntar todo mundo, fazer um esforço” (D1).
}

Nessa mesma linha, Kunsch (1992) defende que a organização universitária em sua estrutura um setor que integre todas as atividades de comunicação. Para a autora, isso 
permitiria até mesmo um maior intercâmbio entre as diversas unidades e destas com a universidade, rompendo a tradição de isolamento.

Em posição oposta, D2 avalia que a criação desse órgão pode gerar nichos de poder, em que prevaleceriam os interesses de grupos ou pessoas, em detrimento da universidade. Para esse(a) docente, em vez de se criar um órgão centralizador, melhor seria trabalhar em rede, promovendo maior diálogo entre os setores. Por fim, para G1, as áreas de comunicação ainda precisam amadurecer e detalhar a proposta de criação da superintendência.

\subsubsection{Perspectivas da criação da Superintendência de Comunicação da UnB}

O Quadro 17 relaciona análises dos entrevistados quanto às perspectivas que envolvem a criação de uma superintendência de comunicação da UnB: principais consequências e etapas para a implantação. 
Quadro 17 - Perspectivas da criação da Superintendência de Comunicação da UnB

\begin{tabular}{|c|c|}
\hline Entrevistados & Perspectivas: consequências e etapas \\
\hline G1 & $\begin{array}{l}\text { - Pode criar maior burocracia e mais problemas, em vez de resolver; } \\
\text { - A realização de seminários pode ser um caminho para a implantação. }\end{array}$ \\
\hline G2 & $\begin{array}{l}\text { - Fortaleceria a estrutura de comunicação; adequaria as pessoas aos cargos; } \\
\text { - Integraria os setores; } \\
\text { - Pode haver resistências; } \\
\text { - É preciso dar continuidade às discussões sobre a implantação. }\end{array}$ \\
\hline G3 & $\begin{array}{l}\text { - Otimizaria os recursos e processos; permitiria mais dinamismo, maior produção e } \\
\text { qualidade dos produtos; integraria os setores; } \\
\text { - Favoreceria a um maior protagonismo dos servidores; } \\
\text { - Não se pode ser imediatista, nem achar que a superintendência resolverá todos os } \\
\text { problemas de comunicação. }\end{array}$ \\
\hline G4 & $\begin{array}{l}\text { - Permitiria planejar e acompanhar o trabalho; } \\
\text { - Favoreceria a um maior protagonismo dos servidores; } \\
\text { - É preciso realizar reuniões com a participação das áreas, estabelecer metas e capacitar os } \\
\text { servidores. }\end{array}$ \\
\hline D1 & $\begin{array}{l}\text { - Ajudaria a integrar o discurso e delimitar o foco das ações; } \\
\text { - Depende de uma vontade política e de negociação entre as áreas. }\end{array}$ \\
\hline D2 & $\begin{array}{l}\text { - Pode se tornar uma instância burocrática e levar à criação de nichos de poder; } \\
\text { - É preciso convencer a alta administração sobre a importância da comunicação para a UnB. }\end{array}$ \\
\hline D3 & $\begin{array}{l}\text { - Melhoraria a gestão da comunicação, com direcionamento estratégico e organização da } \\
\text { força de trabalho; } \\
\text { - Permitiria maior agilidade e autonomia na gestão de recursos; } \\
\text { - Favoreceria a um maior protagonismo dos servidores; } \\
\text { - Depende de vontade política da Reitoria; } \\
\text { - É preciso revisar o documento elaborado pela comissão, fazer um plano de implantação } \\
\text { antes de levar ao Consuni e convencer sobre a importância dessa integração. }\end{array}$ \\
\hline D4 & $\begin{array}{l}\text { - Otimizaria os recursos humanos e equipamentos; } \\
\text { - Permitiria o planejamento de pautas; } \\
\text { - Favoreceria a um maior protagonismo dos servidores; } \\
\text { - Depende de negociação com os setores de comunicação atuais e apoio político por parte da } \\
\text { administração superior. }\end{array}$ \\
\hline S1 & $\begin{array}{l}\text { - Aumentaria a produtividade e abrangência de cobertura; } \\
\text { - Permitiria a compreensão das rotinas e maior incentivo aos servidores, com gratificações; } \\
\text { - É possível que haja resistências; } \\
\text { - Depende de uma chancela administrativa e de um trabalho multidisciplinar para definir a } \\
\text { atuação, missão, atribuição, organização e vinculações. }\end{array}$ \\
\hline $\mathbf{S 2}$ & $\begin{array}{l}\text { - Haveria resistência, devido à diminuição de autonomia de cada setor; } \\
\text { - Potencializaria os trabalhos da comunicação; } \\
\text { - Permitiria maior protagonismo dos servidores; } \\
\text { - Depende de vontade política, com o envolvimento da Reitoria. }\end{array}$ \\
\hline E1 & $\begin{array}{l}\text { - Permitiria maior controle e fiscalização, valorização da comunicação, captação de recursos } \\
\text { e maior protagonismo dos servidores, talvez haja resistências; } \\
\text { - É preciso planejar muito bem quais seriam os objetivos da superintendência; } \\
\text { - É importante que seja agregadora, de apoio e de controle. }\end{array}$ \\
\hline
\end{tabular}

Fonte: Elaboração do autor.

Conforme é possível perceber pelo Quadro 17, na perspectiva dos participantes da pesquisa a superintendência traria consequências positivas, tais como a integração das áreas 
de comunicação, a unificação do discurso e a otimização dos recursos humanos e de equipamentos, proporcionando maior produtividade.

Além dessas questões, já exploradas anteriormente, gestores e docentes entrevistados ressaltaram um aspecto essencial para a viabilidade da superintendência: a autonomia financeira, tendo em vista que se trataria de um órgão complementar, nos termos do Estatuto da UnB (UNIVERSIDADE DE BRASÍLIA, 2011). Dessa forma, a Superintendência de Comunicação da UnB poderia estabelecer convênios e parcerias com fundações de apoio. De acordo com art. $8^{\circ}$ da Proposta de Política de Comunicação Integrada para a UnB, as receitas da superintendência seriam formadas, entre outras fontes, por "recursos oriundos de convênios, contratos e acordos com órgãos ou entidades de governo ou instituições privadas com a finalidade de custear projetos de interesse da Superintendência". Segundo o art. $13^{\circ}$ desse mesmo documento, caberia aos diretores das unidades que integram a superintendência “elaborar projetos de produtos, serviços ou ações que possibilitem captação de recursos por meio de convênios e contratos" (ANEXO G).

Entretanto, G1 e D2 temem que a implantação desse órgão ocasione maior burocratização nos processos de comunicação da UnB. Para esses entrevistados, a criação de uma estrutura do porte de uma superintendência pode envolver mais problemas do que solução, com mais custos para a administração superior da UnB, em um cenário de restrição orçamentária das universidades brasileiras. G1 aponta que uma possibilidade seria um modelo que não dependesse apenas de recursos públicos, por meio de uma fundação de apoio.

Nesse aspecto, vale citar Eisenstadt (1978), o qual define equilíbrio burocrático como uma situação em que a burocracia, dotada de um grau mínimo de autonomia, atende ao interesse público, com regulação política. Conforme o autor, há duas situações de quebra desse equilíbrio: a burocratização, um ganho de autonomia pelo qual o interesse público é restringido por interesses particulares, e a desburocratização, em que a perda de autonomia 
leva à captura do interesse público por alianças entre a burocracia e segmentos externos da sociedade e do sistema político. Nessa tensão, intrínseca à burocracia, há uma tendência à burocratização, que consiste no excesso de formalidades e na baixa eficiência (EISENSTADT, 1978).

Outra consequência negativa apontada pelos entrevistados diz respeito à resistência dos servidores da área de comunicação. S2 é enfático ao afirmar que todo processo de mudança envolve resistência e que a criação desse órgão levaria a uma diminuição da autonomia de cada unidade, em favor de um espaço de maior crítica e análise do que é produzido pelas áreas. Para G2, haveria um choque inicial, pois as pessoas teriam que sair da "zona de conforto" e produzir mais.

Kanter, Stein e Jick (1992) identificam alguns possíveis motivos para as reações contrárias a mudanças por parte dos colaboradores de uma organização, entre os quais: a perda de privilégios ou de controle, no caso de uma reorganização da estrutura orgânica e das funções; a incerteza quanto ao futuro e a perda da hegemonia das competências, decorrente, por exemplo, da introdução de novas tecnologias. Segundo Sleutjes e Oliveira (2013), as universidades caracterizam-se como um sistema eminentemente político, resistente a qualquer mudança, para que prevaleça o status quo vigente.

Por outro lado, parte significativa dos sujeitos da pesquisa avalia que a criação da superintendência pode favorecer a um maior protagonismo dos servidores no planejamento das ações de comunicação da UnB. Nessa perspectiva, D3 afirma que esse aspecto pode se tornar um fator motivacional e de integração, na medida em que os servidores sentirem que estão colaborando com um projeto coletivo, sem que isso seja imposto de cima para baixo. G3 considera que isso já vem ocorrendo no âmbito da Secom, em que o planejamento das ações é feito de forma conjunta. Na avaliação de G3, com a superintendência, isso tende a se fortalecer e ampliar. 
S2 afirma que os servidores técnico-administrativos deveriam ser mais valorizados e aproveitados em cargos de direção, desde que comprovadamente competentes para tanto, inclusive na superintendência. Mas (S2) ressalva que a função de superintendente deve ser mais política, eventualmente podendo ser ocupada por um servidor de carreira, contanto que tenha o perfil adequado.

$\mathrm{Na}$ perspectiva de viabilizar a superintendência, os participantes da entrevista consideram importante a realização de reuniões entre as unidades que vão compor o órgão para tentar estabelecer uma meta em comum. D1 e D3 avaliam que as áreas precisam se sentir parte de uma construção coletiva de algo que pode levar a um aprimoramento, o que envolveria um trabalho de convencimento.

Os entrevistados também avaliam que a superintendência depende de uma vontade política da administração superior, para submeter a proposta de Política de Comunicação Integrada à aprovação do Consuni.

Conforme Kunsch (2003), a área de comunicação precisa estar subordinada à cúpula diretiva e participar da gestão estratégica. Segundo a autora,

(...) se for apenas uma área de suporte ou apoio para atender às necessidades de comunicação, executando tarefas e produzindo veículos comunicacionais, dificilmente conseguirá planejar, pensar e administrar estrategicamente a comunicação, numa perspectiva macro, empreendedora e em consonância com a missão, a visão e os valores organizacionais (KUNSCH, 2003, p. 246).

Nessa perspectiva, Duarte e Monteiro (2009) afirmam que a gestão da comunicação precisa ser assumida por todos os colaboradores da organização, e não apenas pela cúpula diretiva. Genelot (2001) ressalta que a preparação e a evolução da consciência estratégica não devem ser impostas pela cúpula administrativa, pois envolve aspectos complexos de negociação, expressão e apropriação de valores mútuos.

Quanto à observação qualitativa, este pesquisador contribuiu com estudos, proposições e levantamentos para a elaboração da proposta de criação de uma 
superintendência de comunicação da UnB. Verificou-se que há uma grande expectativa de segmentos envolvidos na comunicação da UnB, em especial da equipe da UnBTV e de docentes da Faculdade de Comunicação (FAC/UnB). Por outro lado, ao longo da pesquisa, foi possível perceber que a administração superior da universidade ainda não tem uma posição definida em relação à proposta. Atualmente o processo de implantação desse órgão central encontra-se paralisado, sem discussões ou aprofundamento acerca da superintendência e seus impactos para a comunicação da universidade. 


\subsection{Conclusões gerais sobre a discussão dos dados}

As categorias analisadas, em consonância com os objetivos da pesquisa, possibilitaram conclusões advindas da análise dos dados coletados, por meio da aplicação das entrevistas. Na discussão dos dados, recorreu-se à contextualização relacionada ao arcabouço teórico, adensada à revisão de literatura, bem como à análise documental.

A primeira categoria analisada foi Setores de Comunicação da UnB, em que se buscou verificar o cenário atual da gestão da comunicação da UnB. Para o aprofundamento dos dados coletados, essa primeira categoria foi subdividida em três variáveis, eleitas a partir dos questionamentos das entrevistas: Conhecimento, Avaliação e Perspectivas.

Percebeu-se que o Portal da UnB é o canal de comunicação mais conhecido pelos sujeitos da pesquisa. As entrevistas apontaram que a programação da UnBTV é acompanhada, principalmente, no espaço virtual: transmissões online e vídeos compartilhados pelas redes sociais do canal de TV. A respeito da Rádio UnB, foi relatado que o canal não está operando devido a pendências legais quanto à concessão. Embora possa operar online, ressalvou-se que as instalações atuais são insalubres e que faltam profissionais.

$\mathrm{Na}$ avaliação de parte dos entrevistados, o Portal da UnB não tem conseguido atuar como uma agência de notícias, com foco na divulgação da produção acadêmica. Outras observações relatadas dizem respeito à dificuldade em se localizar documentos oficiais da UnB, e à baixa interação com a UnBTV, por meio de compartilhamento de vídeos do canal Youtube da emissora. De forma geral, os participantes avaliaram que a gestão da comunicação da UnB apresenta problemas e precisa melhorar.

Quanto às perspectivas para os setores de comunicação, envolvendo o diagnóstico de problemas e desafios, foram citadas a falta de envolvimento e de compreensão da comunidade acadêmica sobre os processos de comunicação, a ausência de uma política de comunicação que possa nortear as ações, a falta de profissionais e de valorização dos servidores, 
deficiências da comunicação interna, a precariedade das instalações da Rádio UnB e da UnBTV e a ausência de integração dos setores de comunicação. Os entrevistados relataram algumas alternativas que os setores têm encontrado para resolver a falta de pessoal e foram unânimes em apontar a necessidade de maior integração para se otimizar os recursos humanos e materiais.

A segunda categoria, Planejamento da Comunicação da UnB, objetivou examinar o panorama do planejamento estratégico aplicado à comunicação organizacional no âmbito das IES, em especial da UnB, a partir de duas categorias: Avaliação e Perspectivas.

Os entrevistados apontaram que falta planejamento na comunicação da UnB, pois os setores atuam de forma ainda desarticulada. Nesse contexto, os participantes destacaram a importância de se planejar as ações, a médio e longo prazo.

Os sujeitos da pesquisa apontaram a necessidade de se construir um planejamento estratégico de comunicação, ao qual façam parte o tático e operacional. No nível estratégico, foi indicada a necessidade de os setores trabalharem em conjunto; no tático, de divulgar as ações da UnB, aproximando-a da sociedade, e no operacional, de atender de forma ágil e eficiente às demandas mais imediatas. Foi apontado, ainda, que a Secom e a UnBTV têm atuado muito mais no nível operacional.

Nessa perspectiva, os entrevistados indicaram que o macroplanejamento de comunicação precisa ser construído com a participação dos setores de comunicação e a chancela da alta administração. Também foi apontada a necessidade de se definir metas, estabelecer um sistema de avalição, viabilizar diretrizes de pauta e investir mais em marketing, para reforçar a imagem institucional da UnB junto aos públicos interno e externo.

A Comunicação Organizacional Integrada foi a terceira categoria analisada, no sentido de investigar os desafios para a integração dos setores de comunicação da UnB. Para tanto, foram definidas duas variáveis de análise: Avaliação e Perspectivas. 
Os entrevistados consideraram importante que ocorra essa unificação de esforços para o alcance dos objetivos da instituição, agregando as ações de cada unidade. A integração dos setores de comunicação, segundo os entrevistados, possibilitaria melhor aproveitamento dos recursos humanos, materiais e tecnológicos; melhor coordenação de esforços; melhor comunicação com a sociedade, a partir da unidade de um discurso unificado e maior produtividade, com abrangência das coberturas jornalísticas.

$\mathrm{Na}$ perspectiva de viabilizar a integração, os sujeitos da pesquisa indicaram a necessidade de ocorrer algumas mudanças prévias, tais como: a apresentação de uma proposta convincente, por parte dos profissionais da área; a vontade política; o estabelecimento de diretrizes em comum; o aprendizado de como trabalhar de forma integrada e a criação de um setor que reúna os setores de comunicação e mesmo outras unidades da UnB. Nesse sentido, foram identificados os principais desafios: escolher um modelo que proporcione a integração sem criar maior burocratização; convencer os profissionais da área e a alta administração de que a integração é necessária; superar um eventual comodismo dos profissionais que atuam na área; obter mais recursos humanos e materiais; romper a fragmentação e pensar em conjunto; manter um diálogo permanente entre os setores e integrar os campi da UnB. Ponderou-se, ainda, que é preciso construir um prédio para abrigar os setores de comunicação, em um projeto a longo prazo.

A quarta categoria buscou relacionar experiências de gestão integrada no âmbito da comunicação de universidades públicas brasileiras, que possam servir de modelo para a construção de uma política de comunicação integrada na UnB. A maioria dos entrevistados afirmou conhecer exemplos de superintendência de comunicação em universidades públicas. Foi apontado que tem sido uma tendência nas IES brasileiras a criação de um órgão que centralize a comunicação social, tal como uma superintendência, em diferentes modelos de integração: apenas com os setores de comunicação ou que agregam outras unidades, como 
editora e/ou setor de cultura da universidade. A experiência mais citada foi a Comunica Superintendência de Comunicação da UFRN, a qual serviu de modelo para a elaboração da proposta de uma superintendência de comunicação para a UnB (UNIVERSIDADE FEDERAL DO RIO GRANDE DO NORTE, 2015). Entretanto, apesar de ser considerada uma referência, a Comunica vem enfrentado problemas relacionados à gestão (SINTEST-RN, 2015). Compreender tais dificuldades pode contribuir para o aprimoramento do modelo proposto de superintendência da UnB.

Por fim, na categoria Superintendência de Comunicação da UnB, foi analisado o modelo proposto de superintendência (ANEXO G), a partir de duas categorias: Avaliação e Perspectivas. A maior parte dos entrevistados avaliou que se trata de um meio para o estabelecimento de uma política de comunicação integrada no âmbito da UnB. Entretanto, também foi apontado que as áreas de comunicação precisam amadurecer a proposta.

Para os participantes, a criação de uma superintendência teria, como consequências principais: fortalecimento da estrutura de comunicação; otimização de recursos; maior produtividade, controle e fiscalização; compreensão das rotinas de trabalho; unidade do discurso; possibilidade de captação de recursos; e maior capacitação e protagonismo dos servidores. Por outro lado, destacou-se que a criação do órgão pode gerar resistência, tendo em vista a diminuição da autonomia de cada setor. Também se ressalvou que a superintendência pode significar uma maior burocracia e aumento de gastos.

Nessa perspectiva, os entrevistados identificaram algumas etapas necessárias para a implantação de uma superintendência de comunicação na UnB, entre as quais, a realização de encontros entre os envolvidos. Enfatizou-se a necessidade de negociação entre as áreas e de convencimento sobre a importância da criação de um órgão centralizador. Segundo alguns entrevistados, a primeira etapa já foi cumprida: a elaboração da proposta de estabelecimento 
da Política de Comunicação Integrada (ANEXO G), encaminhada à Vice-Reitoria em junho de 2014. Entretanto, conforme relato de entrevistados, não houve continuidade dos debates.

Portanto, por meio da análise dos resultados dos dados, a conclusão do estudo de caso sobre a integração do sistema comunicacional da UnB é que a criação de uma superintendência de comunicação é um caminho adequado para promover a integração e maior sinergia entre os setores de comunicação da universidade. 


\section{Conclusão}

Uma famosa imagem é comumente usada para representar as falhas e dificuldades no processo de comunicação: a figura de três macacos, um que não quer ver, um que não quer ouvir e outro que não quer falar.

Figura 15 - Problemas na comunicação

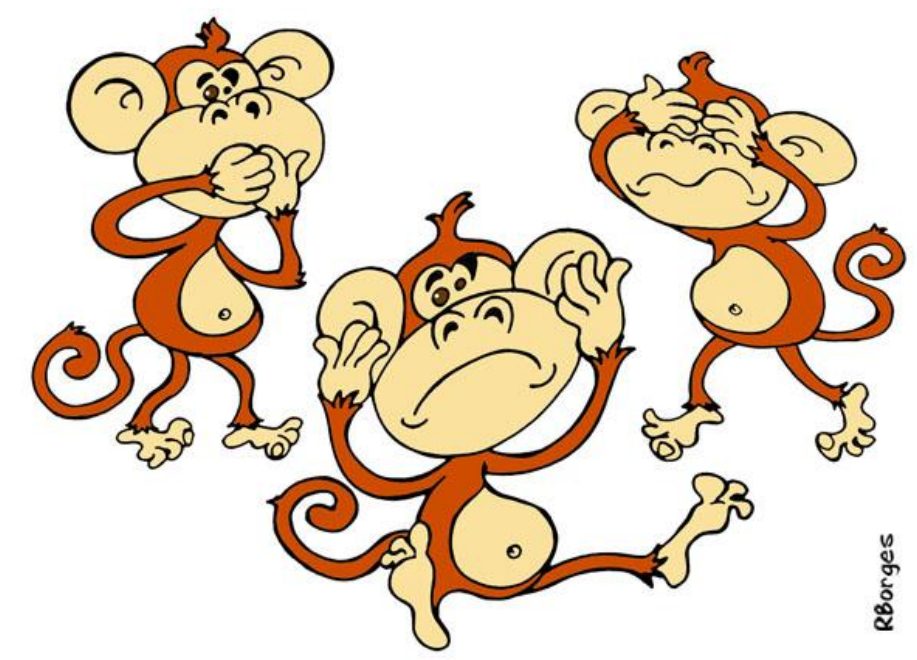

Fonte: Elaboração do autor.

Tal imagem pode representar, de forma simbólica, os problemas recorrentes na gestão da comunicação no âmbito das organizações. Afinal, para se atingir uma comunicação eficiente e eficaz, em primeiro lugar, é preciso querer comunicar bem. Mas, nem sempre, as organizações percebem o papel estratégico da comunicação social para atingir a sua missão e objetivos, e acabam por se posicionar como a figura citada, com cada setor de comunicação funcionando de forma isolada, sem diálogo. Dessa forma, dificilmente essas organizações conseguirão se comunicar de forma eficaz e eficiente com os seus públicos e com a sociedade.

Compreender as causas dessas deficiências e analisar as alternativas para o estabelecimento de uma comunicação organizacional integrada, mais especificamente no âmbito da UnB, foi o ponto de partida da jornada desta pesquisa. A integração dos setores CPCE/UnBTV, Rádio UnB e Secom - é uma necessidade premente, prevista no PDI/UnB 2014-2017 (UNIVERSIDADE DE BRASÍLIA, 2015b). 
No sentido de efetivar a integração desses setores, encontra-se em discussão a proposta de Política de Comunicação Integrada da Universidade de Brasília, a qual prevê a criação de uma superintendência de comunicação. A presente dissertação buscou analisar se essa proposta - idealizada pela própria área - pode, e de que forma, levar à integração da comunicação da UnB.

$\mathrm{Na}$ trajetória desta pesquisa, foi realizado um diagnóstico acerca do cenário atual da gestão da comunicação na UnB. Percebeu-se que a Secom e a UnBTV continuam a atuar sem coordenação das ações, o que tem contribuído para uma percepção negativa da comunicação da universidade, especialmente no âmbito interno. Já a Rádio UnB ainda não está operando, devido a um imbróglio jurídico (ANEXO F). A falta de profissionais e as instalações insalubres impedem que a emissora funcione no ambiente online. Dessa forma, verificou-se que ainda prevalece a improvisação e o informalismo na comunicação da UnB, com soluções paliativas à falta de profissionais e de infraestrutura adequada.

Outrossim, constatou-se a ausência de um planejamento estratégico aplicado à comunicação da universidade. Conforme foi possível constatar, a UnBTV e a Secom atuam muito mais no nível operacional, sem macroplanejamento e visão estratégica, que possibilitem a integração dos setores de comunicação da UnB.

Dessa forma, ficou evidenciada na percepção dos entrevistados a falta de sinergia entre os setores. Nesse sentido, identificou-se a necessidade do estabelecimento de uma política de comunicação integrada, conforme apontado pela literatura (BUENO, 2002; KUNSCH, 2003; NEVES, 2000; TORQUATO DO REGO, 2015) e pelas entrevistas desta pesquisa. Entretanto, verificou-se que essa integração depende, em grande medida de uma vontade política da alta administração e do convencimento dos próprios envolvidos, uma vez que resistências são inerentes ao processo de mudança organizacional. A pesquisa apontou, ainda, que o modelo proposto de criação de uma superintendência de comunicação tem sido 
adotado com êxito em outras IES públicas. Muitos desses órgãos conseguem driblar as dificuldades financeiras das universidades públicas captando recursos por meio de projetos e do auxílio de fundações de apoio.

Portanto, conclui-se que a criação da Superintendência de Comunicação da UnB é um caminho viável, já testado em outras IES, para melhor gerir as ações dos setores, visando fortalecer a marca institucional e otimizar os recursos. Entretanto, faz-se necessário garantir que esse órgão, caso seja criado, disponha de espaços e processos democráticos de diálogo e de escolha dos gestores da superintendência.

Por fim, recomenda-se que a Proposta de Política de Comunicação Integrada para a UnB seja amplamente debatida, com a realização de encontros e seminários e a efetiva participação dos profissionais de comunicação e da administração superior.

Espera-se que o presente estudo auxilie no aprofundamento das discussões acerca do tema, contribuindo para subsidiar a efetivação de uma política de comunicação estratégica, a serviço de uma comunicação eficiente, ágil e integrada.

Figura 16 - Comunicação integrada

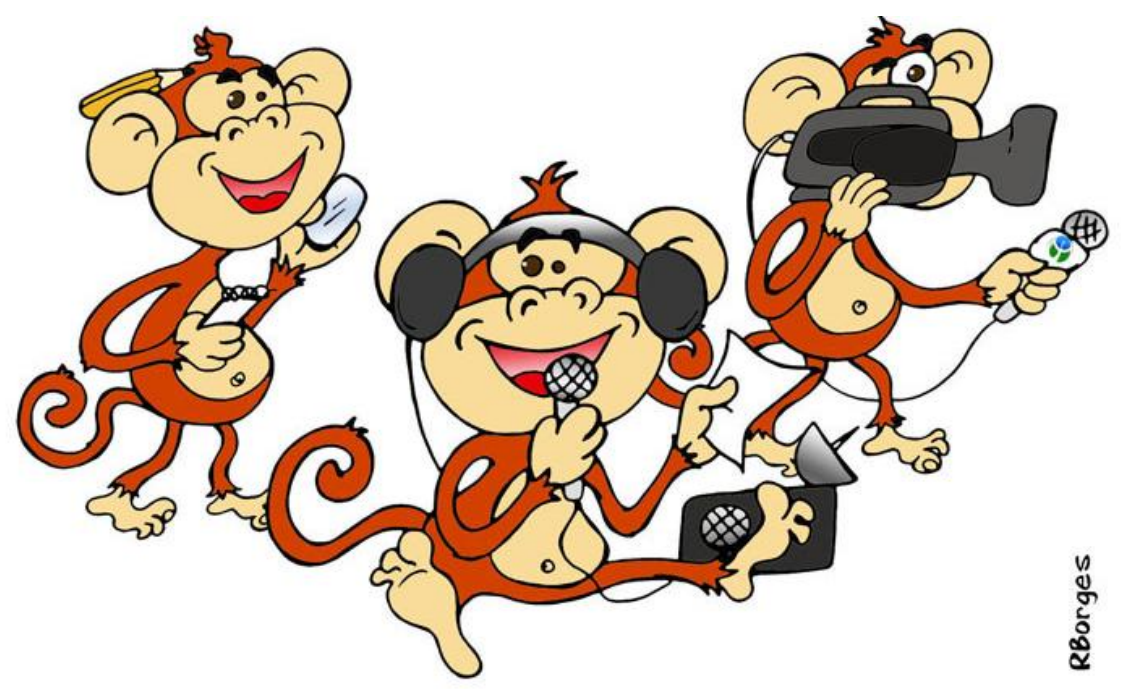

Fonte: Elaboração do autor. 


\section{Referências}

ACKOFF, Russell L. Planejamento empresarial. Rio de Janeiro: LTC, 1978.

ALAMI, Sophie; DESJEUX, Dominique; MOUSSAOUI, Isabele Garabuau. Os Métodos Qualitativos. Petrópolis. Rio de Janeiro: Vozes, 2010.

ALBUQUERQUE, Adão Eunes. Planejamento das relações públicas. Porto Alegre: Acadêmica, 1981.

ALENCAR, Edgard. Introdução à metodologia de pesquisa social. Lavras: UFLA/FAEPE, 2000 .

ALVES-MAZZOTI, Alda Judith; GEWANDSZNAJDER, Fernando. O método nas ciências naturais e sociais. São Paulo: Thomson, 2001.

ANDRÉ, Marli Eliza Dalmazo Afonso de. Estudo de caso em pesquisa e avaliação educacional. Brasília: Líber Livro Editora, Série Pesquisa em Educação, vol.13, 2005.

ANDREWS, Patricia Hayes; HERSCHEL, Richard T.; BAIRD, John E. Organizational communication: Empowerment in a technological society. Houghton Mifflin College Division, 1996.

ARAÚJO, Maria Arlete Duarte. Planejamento estratégico: um instrumental à disposição das universidades? Revista de Administração Pública, v. 30, n. 4, p. 74-86, 1996.

BALDISSERA, Rudimar. Comunicação organizacional: o treinamento de recursos humanos como rito de passagem. São Leopoldo: Unisinos, 2000.

BALDRIDGE, J. V. e DEAL, T. The dynamics of organizational change in educations. California: McCutchan Publishing Corporation, 1983.

BAPTISTA, Myrian Veras. Planejamento social: intencionalidade e instrumentação. São Paulo: Veras Editora, 2000.

BARDIN, Laurence. Análise de Conteúdo. São Paulo: Edições 70, 2011.

BERLO, David. O processo de comunicação: introdução à teoria e à prática. São Paulo: Martins Fontes, 2003.

BLAU, Peter e SCOTT, Richard W. Organizações formais: uma abordagem comparativa. São Paulo, Atlas, 1979.

BODINI, Vera Lúcia. Planejamento estratégico em universidades. Encontro Nacional de Engenharia de Produção. (XVIII: 1998: Niterói) Anais... Niterói: Universidade Federal Fluminense, 1998. Disponível em:

<http://www.abepro.org.br/biblioteca/ENEGEP1998_ART139.pdf >. Acesso em: 25 jul. 2015. 
BOGDAN, Robert C.; BIKLEN, Sari K. Investigação qualitativa em educação: uma introdução à teoria e aos métodos. Porto, Portugal: Porto, 1994.

BONI, Valdete; QUARESMA, Sílvia Jurema. Aprendendo a entrevistar: como fazer entrevistas em Ciências Sociais. Revista Eletrônica dos Pós-Graduandos em Sociologia Política da UFSC. Santa Catarina, v. 2, n. 1 (3), jan-jul, 2005. Disponível em: <https://periodicos.ufsc.br/index.php/emtese/article/viewFile/18027/16976>. Acesso em: 30 out. 2014.

BUONO, Anthony F.; BOWDITCH, James L. Elementos de comportamento organizacional. São Paulo: Pioneira, 1992.

BRANDÃO, Elizabeth Pazito. Conceito de comunicação pública. In: DUARTE, Jorge. (Org.). Comunicação Pública: Estado, Mercado, Sociedade e Interesse Público. São Paulo: Atlas, p. 1-33, 2007.

BRASIL. Lei n. ${ }^{\circ}$ 3.998, de 15 de dezembro de 1961, que autoriza o Poder Executivo a instituir a Fundação Universidade de Brasília, e dá outras providências. Disponível, em: <http://www2.camara.leg.br/legin/fed/lei/1960-1969/lei-3998-15-dezembro-1961-376850publicacaooriginal-1-pl.html>. Acesso em: 25 jul. 2015.

Lei n. ${ }^{\circ}$ 8.977, de 6 de janeiro de 1995, que dispõe sobre o Serviço de TV a Cabo e dá outras providências. Disponível em: <http://www.planalto.gov.br/ccivil_03/leis/18977.htm>. Acesso em: 30 out. 2014.

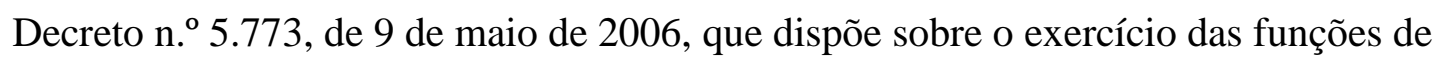
regulação, supervisão e avaliação de instituições de educação superior e cursos superiores de graduação e seqüenciais no sistema federal de ensino. Disponível em: <http://www.planalto.gov.br/ccivil_03/_ato2004-2006/2006/Decreto/D5773.htm>. Acesso em: 25 jul. 2015.

Lei n. ${ }^{\circ} 11.652$, de 7 de abril de 2008, que institui os princípios e objetivos dos serviços de radiodifusão pública explorados pelo Poder Executivo ou outorgados a entidades de sua administração indireta;. Disponível em: <http://www.planalto.gov.br/ccivil_03/_ato2007-2010/2008/lei/111652.htm>. Acesso em: 13 set. 2015.

BUENO, Wilson da Costa. Comunicação e gestão empresarial: cenários contemporâneos. in: Communicare. São Paulo: Paulus, 2002.

CABRAL, Valéria. Um ensaio sobre a comunicação interna pós-industrial em sua dicotomia discurso e prática. Revista Organicom, v. 1, n. 1, p. 55-71, 2011

CAMATTI, Tassiara Baldissera. A Ouvidoria na Universidade pública: probabilidades e improbabilidades da comunicação. Tese de Doutorado. PPGCOM. PUCRS, 2014.

CAPRA, Fritjof. As conexões ocultas: ciência para uma vida sustentável. São Paulo: Editora Cultrix, 2005. 
CARDOSO, Onésimo. Comunicação empresarial versus comunicação organizacional: novos desafios teóricos. Revista de Administração Pública (RAP) Rio de Janeiro, v. 40, n. 6, p. 1123-44, 2006.

CARVALHO, Horácio Martins de. Introdução à teoria do planejamento. 2. ed. São Paulo: Brasiliense, 1976.

CASTELLS, Manuel. A galáxia da internet - reflexões sobre a internet, os negócios e a sociedade. Rio de Janeiro: Jorge Zahar, 2003. 1999.

A sociedade em rede. vol. 1. Economia, sociedade e cultura. São Paulo: Paz e Terra,

CASTRO, Antonio Maria Gomes de; LIMA, Suzana Maria Valle; BORGES-ANDRADE, Jairo Eduardo. Metodologia de planejamento estratégico das unidades do MCT. Brasília: Ministério da Ciência e Tecnologia, Centro de Gestão e Estudos Estratégicos, 2005.

CASTRO, Maria Céres Pimenta Spínola. Os desafios da Comunicação Pública na Universidade Pública, campus São Carlos da UFSCar, 2 dez. 2013. Palestra.

Disponível em: <http://www.ccs.ufscar.br/relatorios/os-desafios-da-comunicacao-publica-nauniversidade-publica/at_download/file>. Acesso em: 6 jun. 2013.

CASTRO, Valéria. Comunicação nas organizações. Rio de Janeiro: Coppead/UFRJ, 1998.

CERVO, Amado Luiz; BERVIAN, Pedro Alcino. Metodologia científica. $5^{\text {a }}$ edição. São Paulo: Ed. Prentice Hall, 2002.

CHIZZOTTI, Antonio Maria Gome de. Pesquisa em ciências humanas e sociais. 4. ed. São Paulo: Cortez, 2000. - (Biblioteca da educação. Serie 1. Escola; v. 16.

COLLADO, Carlos Fernández; SAMPIERI; Roberto Hernández; LUCIO, Pilar Baptista. Metodologia de Pesquisa. 3. ed. São Paulo: McGraw-Hill, 2006.

COSTABILE, Lúcio Tadeu. Desenvolvimento de um Plano Estratégico em uma Instituição de Ensino Superior. 2007. 124 p. Dissertação (Mestrado em Engenharia Mecânica) - Faculdade de Engenharia Mecânica, Universidade Estadual de Campinas, Campinas.

CUNHA, Cristiano José Castro Almeida. Planejamento estratégico em universidades. NEST- Núcleo de Estudos - Departamento de Engenharia de Produção, UFSC, Florianópolis, 1995.

DIAS, José Maria A. M. Planejamento organizacional: conceitos e tendências. In: VASCONCELLOS FILHO, Paulo de et al. (Org.). Planejamento empresarial: teoria e prática. Leituras selecionadas. Rio de Janeiro: LTC, 1982.

DUARTE, Jorge (Org.). Comunicação pública: estado, mercado, sociedade e interesse público. São Paulo: Atlas, 2007. 
Entrevista em profundidade. In: DUARTE, Jorge; BARROS Antonio (Org.).

Métodos e técnicas de pesquisa em comunicação. 2. ed. São Paulo: Atlas, 2012.

Comunicação Pública. Disponível em:

<http://www.jforni.jor.br/forni/files/ComP\%C3\%BAblicaJDuartevf.pdf $>$. Acesso em: 11 abr. 2015.

DUARTE, Jorge; MONTEIRO, Graça. Potencializando a comunicação nas organizações. In: KUNSCH, Margarida Maria Krohling (Org.). Comunicação Organizacional: v. 2.

Linguagem, gestão e perspectivas. São Paulo: Saraiva, 2009, p. 333-359.

DUCK, Jeanine. Gerenciando a mudança: a arte do equilíbrio. In: Gestão da mudança. Rio de Janeiro: Elsevier, 2005.

EISENSTADT, Shamuel Noah. Burocratização e desburocratização. In: CAMPOS, Edmundo (Org.). Sociologia da burocracia. Rio de Janeiro: Zahar, 1978.

ESTRADA, Rolando Juan Soliz. Os rumos do planejamento estratégico na universidade pública. 2000. 206f. Tese (Doutorado em Engenharia de Produção) - Departamento de Engenharia de Produção e Sistemas, Universidade Federal de Santa Catarina, Florianópolis.

ETZIONI, Amitai. Análise comparativa de organizações complexas: sobre o poder e engajamento e seus correlatos. Rio de Janeiro, Zahar, e São Paulo, Editora da Universidade de São Paulo.

FARIA, Jairo; PAULINO, Fernando O. Agentevê: uma proposta de programa de ouvidoria para a UnBTV. Disponível em:

<http://www.intercom.org.br/papers/regionais/centrooeste2010/expocom/EX21-0368-1.pdf $>$. Acesso em: 15 abr. 2015.

FARIA, A. Nogueira; SUASSUNA, Ney Robinson. A comunicação na administração. Rio de Janeiro: LTC, 1982.

FERNANDES, Bruno Henrique Rocha; BERTON, Luiz Hamilton. Administração

estratégica: da competência empreendedora à avaliação de desempenho. São Paulo: Saraiva, 2005.

FISCHMANN, Adalberto Américo; ALMEIDA, Martinho Isnard Ribeiro de. Planejamento estratégico na prática. 2. ed. São Paulo: Atlas, 1991.

FRANCO, Maria Clara Publisi Barbosa. Análise de conteúdo. 3 ed. Brasília: Liber Livro, 2008.

FREIRE, Paulo. Extensão ou comunicação? 10. ed. Rio de Janeiro: Paz e Terra, 1977.

FREITAS, S.G. Cultura organizacional e comunicação. In: M.K. KUNSCH (Org.).

Obtendo resultados com relações públicas. São Paulo, Thomson Pioneira, 2004. 
GANDIN, Danilo. A prática do planejamento participativo: na educação e em outras instituições, grupos e movimentos dos campos cultural, social, político, religioso e governamental. 8. ed. Petrópolis: Vozes, 2000.

GENELOT, Dominique. Manager dans la complexité — reflexions à l'usage des dirigents. 3. ed. Paris: Insep Consulting, 2001.

GERALDES, Elen. Política de comunicação nas organizações: a terceira esfera. In: FORMIGA SOBRINHO, Asdrubal Borges (Org.). Muito além dos meios: comunicação organizacional, desafios e interfaces. Brasília, 2014.p. 130-138.

GIL, Antonio Carlos. Como elaborar projetos de pesquisa. São Paulo: Atlas, 1996.

GOLDHABER, Gerald M. Comunicación Organizacional. México: Editorial Diana, 1991

HABERMAS, Jürgen. Consciência moral e agir comunicativo. Rio de Janeiro: Tempo Brasileiro, 1989.

HALL, Richard H. Organizações: estrutura e processos. 3. ed. Rio de Janeiro: Prentice-Hall do Brasil Ltda., 1984.

IANHEZ, João Alberto. Relações Públicas nas organizações. In: KUNSCH, Margarida Maria Krohling (Org.). Obtendo resultado com relações públicas. São Paulo: Pioneira Thmpson Learning, 1997, p.181-189.

IPEA - INSTITUTO DE PESQUISA ECONÔMICA APLICADA. Práticas inovadoras de gestão nas áreas administrativas de planejamento das instituições federais de ensino superior. Brasília, 2005.

JENKINS, Henry. Cultura da convergência. 2.ed. São Paulo, 2009.

Kanter, R. M., Stein, B. A., \& Jick, T. D. (1992). The Challenge of Organizational Change. New York: Free Press.

KATZ, Daniel e KAHN, Robert L. Psicologia social das organizações. 2. ed. São Paulo: Atlas, 1978.

KREEPS, Gary. La comunicación en las organizaciones. 2. ed. Wilmington, Delaware, USA: Addison-Wesley Ibero Americana, 1995.

KOONTZ, Harold; O’DONNELL, Cyril. Princípios da administração: uma análise das funções administrativas. Trad. De Albertino Pinheiros e Ernesto D’Orsi. 1 v. 6. ed. São Paulo: Pioneira, 1973.

KOTLER, Philip; ARMSTRONG, Gary. Princípios de marketing. 12 ed. São Paulo: Prentice-Hall, 2008.

KOTLER, Philip; KELLER, Kevin Lane. Administração de marketing. 12. ed. São Paulo: Prentice Hall, 2006. 
KUNSCH, Margarida Maria Krohling. Universidade e comunicação na edificação da sociedade. São Paulo: Loyola, 1992.

Planejamento de Relações Públicas na Comunicação Integrada. São Paulo: Summus, 2003.

(Org.). Gestão estratégica em comunicação organizacional e relações públicas. Caetano do Sul: Difusão, 2009.

Relações Públicas e Comunicação Organizacional: das práticas à institucionalização acadêmica. Revista Organicom, v. 6, n. 10/11, 2011. Disponível em:

$<$ http://www.eca.usp.br/departam/crp/cursos/posgrad/gestcorp/organicom/re_vista1011/49.pdf>. Acesso em: 7 jun. 2015.

Comunicação Pública, Sociedade e Universidade. In: MULTICOM, $1^{\circ}$ ENCONTRO MULTICAMPI DE COMUNICAÇÃO DA UNEB, Salvador, BA, 2013. Disponível em: <https://www.youtube.com/watch?v=K5Lbbd7r-DU> Acesso em 8 jun. 2015.

LAKATOS, Eva Maria; MARCONI, Marina de Andrade. Metodologia Científica. rev. e ampl. São Paulo: Editora Atlas, 2004.

LITTLEJOHN, Stephen W. Fundamentos Teóricos da Comunicação Humana. Rio de Janeiro: Ed. Guanabara, 1988.

LUDKE, Menga; ANDRÉ, Marli. Pesquisa em Educação: abordagens qualitativas. São Paulo: EPU, 1986, p. 11-24.

LUPETTI, Marcélia. Gestão estratégica da comunicação mercadológica. São Paulo: Cengage Learning, 2009.

MAGALHÃES, Cláudio. TV universitária: uma televisão diferente. Disponível em: <http://www.abtu.org.br >. Acesso em: 30 out. 2014.

MAIOCHI, Neusa Fátima. As Organizações Universitárias e o Processo de Decisão. In: FINGER. Almeri Paulo (Org.). Gestão de Universidades: novas abordagens. 20 ed. Curitiba: Champagnat, 1997. p.215-294.

MARCELINO, Gileno Fernandes. Gestão Estratégica de Universidade - A construção da Face/UnB. 1. ed. Brasília: Editora Universidade de Brasília, 2004. v. 1. 240p.

MARCHIORI, Marlene. Reflexões iniciais sobre a comunicação como processo nas organizações da contemporaneidade. Intercom Sul, 2010.

MARQUES DE MELO, José. Comunicação Social: teoria e pesquisa. 4. ed. Petrópolis: Vozes, 1975.

MATOS, H. Comunicação pública, esfera pública e capital social. In: DUARTE. J. (Org.). Comunicação Pública: Estado, Mercado, Sociedade e Interesse Público. 2. ed. São Paulo: Atlas, 2007. p. 47-58. 
MEGGINSON, Leon C; MOSLEY, Donald C; PIETRI JUNIOR, Paul H. SLACK, Nigel; CHAMBERS, Stuart; HARLAND, Cristine; HARRISON,Alan; JHONSTON, Robert. Administração: conceitos e aplicações. 4. ed. São Paulo: Harbra, 1998.

MIRANDA, Nair A. Sistema de planejamento estratégico da UnB. In: MARCELINO, Gileno Fernandes. (Org.) Gestão Estratégica de Universidade: A construção da FACE/UnB. 1. ed. Brasilia: Editora Universidade de Brasília, 2004. v. 1, p. 41-60.

MONTEIRO, Graça França. A singularidade da comunicação pública. In: DUARTE. J. (Org.). Comunicação Pública: Estado, Mercado, Sociedade e Interesse Público. 2 ed. São Paulo: Atlas, 2007. p. 34-46.

MOREIRA, Júlio César Tavares; PASQUALE, Perrotti Pietangelo; DUNER, Alan Gilbert. Dicionário de termos de marketing. 4. ed. São Paulo: Futura, 2003.

NASSAR, Paulo; FURNALETTO, Matheus; FIGUEREDO, Suzel. A trajetória da Comunicação Organizacional brasileira e o seu perfil atual In: Congresso Brasileiro Científico de Comunicação Organizacional e de Relações Públicas - Abrapcorp, 3, 2009, São Paulo, SP. Anais (on-line). São Paulo: Abrapcorp, 2009. Disponível: <http://www.abrapcorp.org.br/anais2009> Acesso em 06 jun. 2015.

NOVELLI, Ana Lucia Coelho Romero. O papel institucional da comunicação pública para o sucesso da governança. IN: Organicom: revista brasileira de comunicação organizacional e relações públicas. Ano 3, n. 4, 2006.

OLIVEIRA, Elaine Lima de. Revista Universidade - A Busca para Qualidade. São Paulo: IBRAQS, 1994.

OLIVEIRA, Djalma Pinho Rebouças. Estratégia Empresarial e Vantagem Competitiva: como estabelecer, implementar e avaliar. 3. ed. São Paulo: Atlas, 2001.

Atlas, 2003.

Planejamento estratégico: conceitos, metodologias e práticas. 19. ed. São Paulo:

OLIVEIRA, Ivone de L.; PAULA, Maria Aparecida. O que é comunicação estratégica nas organizações? São Paulo: Paulus, 2007.

PATTON, M. Qualitative research \& evaluation methods. Thousand Oaks, CA: Publication. 2002.

PEIXOTO, Fabiana; PRIOLLI, Gabriel. A televisão Universitária no Brasil. Os Meios de Comunicação nas Instituições Universitárias da América Latina e Caribe. Disponível em: <http://unesdoc.unesco.org/images/0013/001399/139903por.pdf> Acesso em: 15 abr. 2015 .

PERROW, Charles. Análise Organizacional: um enfoque sociológico. São Paulo, Atlas, 1972.

PINHO, José Benedito. Comunicação nas organizações. Viçosa: UFV, 2006. 
PRIOLLI, Gabriel. TV universitária: TV Educativa em Terceiro Grau. 26 ago. 2004. Disponível em http://noticias.universia.com.br/materia.jsp?materia=4843. Acesso em: 29 set. 2015.

RAMALHO, Alzimar Rodrigues. O perfil da TV universitária e uma proposta de programação interativa. 2010. Tese de Doutorado. Universidade de São Paulo.

REDFIELD, Charles E. Comunicações administrativas. Trad. de Sylla Magalhães Chaves. 4. ed. Rio de Janeiro: FGV, 1980.

RIBEIRO, Darcy. A universidade necessária. 4. ed. Rio de Janeiro. Paz e Terra, 1982.

ROBBINS, S. Comportamento Organizacional. São Paulo: Prentice Hall, 2002.

ROBSON, Colin. Real world research. A resource for social scientists and practitionerresearches. Oxford: Blackwell, 1993.

SANTOS, Rogério. Os novos media e o espaço público. Lisboa: Gradiva, 1998.

SCROFERNEKER, Cleusa Maria Andrade. Perspectivas teóricas da comunicação organizacional. In: CONGRESSO BRASILEIRO DE CIÊNCIAS DA COMUNICAÇÃO INTERCOM, 23, Manaus, 2000. Anais... Manaus, 2000.

Os (des)caminhos da comunicação na implantação do programa de qualidade total da universidade brasileira. Educação Brasileira, Brasília, v. 23, n. 46, p. 75-91, jan./jun. 2001.

SELLTIZ; WRITSMAN; COOK. Métodos de pesquisa nas relações sociais. 2 ed. São Paulo: EPU, 1987.

SINTEST-RN. Carta Aberta dos Servidores da Comunica à Reitora Ângela Paiva e à Comunidade Universitária e à Sociedade. Disponível em:

<http://sintestrn.org.br/2015/forum-de-servidores-da-comunica-publica-carta-aberta-a-reitoraangela-paiva-a-comunidade-universitaria-e-a-sociedade>.

Acesso em: 9 set. 2015.

SLEUTJES, M.H.; OLIVEIRA, F.B. A crise e a busca de autonomia nas universidades federais brasileiras. Revista de Administração Pública. Rio de Janeiro, v. 32, n. 3, p. 29-46, 2013.

SOUSA, Jorge Pedro. Elementos de teoria e pesquisa da comunicação e dos media. 2. ed. rev. e ampl. Porto, 2006. Disponível em: 〈www.bocc.ubi.pt〉. Acesso em: 20 maio 2015.

STAKE, Robert E. A arte da Investigação com estudos de caso. Lisboa: Fundação Calouste Gulhenkian, 2007.

TAVARES, Maurício. Comunicação Empresarial e Planos de Comunicação. 3. ed. São Paulo. Atlas, 2010. 
TORQUATO DO REGO, Francisco Gaudêncio. Comunicação empresarial/comunicação institucional: conceitos, estratégias, sistemas, estrutura, planejamento e técnicas. São Paulo: Summus, 1986.

Tratado de comunicação organizacional e política. São Paulo: Pioneira, 2002.

Comunicações nas organizações: empresas privadas, instituições e setor público.

São Paulo: Summus, 2015.

TOUSIGNANT, Jacques. Planejamento estratégico na universidade: o caso da Universidade de Quebec. Natal, UFRN, 1990.

TRIVIÑOS, Augusto Nibaldo Silva. Introdução à pesquisa em ciências sociais: a pesquisa qualitativa em educação. São Paulo: Atlas, 1990.

ÚLTIMO SEGUNDO. UnB: prejuízo foi de R \$ 20 milhões. O cultural é inestimável. Último acesso:

$<$ http://ultimosegundo.ig.com.br/educacao/unb+prejuizo+foi+de+r+20+milhoes+o+cultural+e +inestimavel/n1300078279499.html > Acesso em 21 set. 2015.

UNIVERSIDADE DE BRASÍLIA. Estatuto e Regime Geral da Universidade de Brasília, publicado no DOU n.7, de 11/1/1994. Brasília: UnB, 8. ed., 2011. p. 7-28. Disponível em: 〈http://www.unb.br/unb/transparencia/downloads/regimento_estatuto_unb.pdf $>$.

Acesso em: 30 out. 2014.

. Relatório de Autoavaliação Institucional da Universidade de Brasília (UnB) 2011. (2014a). Disponível em:

$<$ http://www.dpo.unb.br/documentos/relatorio_autoavaliacao_2011.pdf $>$. Acesso em: 30 out. 2014.

. Relatório de Autoavaliação Institucional da Universidade de Brasília (UnB) 2012. (2014b). Disponível em:

<http://www.dpo.unb.br/documentos/relatorio_autoavaliacao_2012.pdf $>$. Acesso em: 30 out. 2014.

. Relatório de Autoavaliação Institucional da Universidade de Brasília (UnB) 2013. (2014c). Disponível em:

<http://www.dpo.unb.br/documentos/relatorio_autoavaliacao_2013.pdf >. Acesso em: 30 out. 2014.

Secretaria de Comunicação (2014d). Disponível em:

<http://www.secom.unb.br >. Acesso em: 30 out. 2014.

2014.

Quem somos (2014e). Disponível em: 〈http://www.unbtv.br>. Acesso em: 30 out.

. Relatório de Autoavaliação Institucional da Universidade de Brasília (UnB)

2014. (2015a). Disponível em:

〈http://www.dpo.unb.br/documentos/relatorio_autoavaliacao_2014.pdf $>$. Acesso em: 15 abr. 2015. 
Plano de Desenvolvimento Institucional 2014-2017. (2015b). Disponível em: <http://www.dpo.unb.br/documentos/PDI/PDI_2014-2017.pdf >. Acesso em: 15 abr. 2015.

Relatório de Gestão do Exercício de 2014. (2015c). Disponível em:

<http://www.dpo.unb.br/documentos/Relatorio_Gestao_2014.pdf $>$. Acesso em 15 abr. 2015.

. FAC, tradição no ensino de Comunicação Social (2014e). Disponível em:

〈http://fac.unb.br/instituicao $\rangle.$ Acesso em: 30 out. 2014.

UNIVERSIDADE FEDERAL DE GOIÁS. Relatório de Gestão 2014-2017. Disponível em https://www.ufg.br/p/7554-relatorio-de-gestao-2014-2017 Acesso em: 9 de set. 2015.

UNIVERSIDADE DE SÃO PAULO. Sobre a SCS. Disponível em: 〈http://www.scs.usp.br > Acesso em: 30 de out. 2014.

UNIVERSIDADE FEDERAL DE SÃO CARLOS. A CCS. Disponível em:

<http://www.ccs.ufscar.br>. Acesso em: 9 set. 2015

UNIVERSIDADE FEDERAL DO ESPÍRITO SANTO. (2015a). Superintendência de Cultura e Comunicação (Supecc). Disponível em:

$\langle$ http://www.UFES.br/superintendência-de-cultura-e-comunicação-supecc >. Acesso em 20 de maio 2015.

UNIVERSIDADE FEDERAL DO ESPÍRITO SANTO. (2015b). Resolução n.․ 08/2012.

Disponível em:

〈http://daocs.UFES.br/sites/daocs.UFES.br/files/field/anexo/resolucao_08.2012.pdf>. Acesso em 20 maio 2015.

UNIVERSIDADE FEDERAL DO PIAUÍ. (2015a). Órgãos Suplementares. Disponível em: <http://www.ufpi.br/cede/index/pagina/id/7872>. Acesso em: 20 maio 2015.

UNIVERSIDADE FEDERAL DO PIAUÍ. (2015b). Superintendência de Comunicação

Social - SCS. Disponível em:

<http://ufpi.br/subsiteFiles/proplan/arquivos/files/8-

Apresentacao_Comunicacao_com_Sociedade_SCS.pdf>. Acesso em: 20 maio 2015.

UNIVERSIDADE FEDERAL DO RIO GRANDE DO NORTE. Comunica. Disponível em: <http://www.comunica.ufrn.br/conteudo/apresentacao.htm>. Acesso em: 30 out. 2014.

UNIVERSIDADE FEDERAL DO RIO GRANDE DO NORTE. Resolução no 004/15 Consuni, de 13 de março de 2015, que aprova o Regimento Interno da Superintendência de Comunicação - COMUNICA, da UFRN. Disponível em:

<https://sipac.ufrn.br/public/baixarBoletim.do?publico=true\&idBoletim=1758 $>$.

Acesso em: 20 maio 2015.

UNIVERSIDADE FEDERAL FLUMINENSE. Superintendência de Comunicação Social (SCS). Disponível em: <http://www.scs.uff.br>. Acesso em: 30 de out. 2014. 
VASCONCELLOS FILHO, Paulo de; FERNANDES, Marcos Antônio da Cunha.

Planejamento estratégico: vantagens e limitações. Fundação JP, v. 9, n. 12, p. 880-896, 1979.

VASCONCELOS, Luciene Ricciotti. Planejamento de comunicação integrada: manual de sobrevivência para as organizações do século XXI. Summus Editorial, 2009.

WANDERLEY, Luiz Eduardo. O que é universidade. 4. ed. São Paulo: Brasiliense, 1985.

WATZLAWICK, Paul, BEAVIN, Janet Helmick e JACKSON, Don D. Pragmática da comunicação humana. São Paulo: Cultrix, 1967.

WOLTON, Dominique. Pensar a comunicação. Algés, Portugal: Difel, 1997.

YANAZE, Mitsuru. Gestão de marketing e comunicação: avanços e aplicações. 2. ed. São Paulo: Saraiva, 2011.

YIN, Robert K. Estudo de caso: planejamento e métodos. 3. ed. Porto Alegre: Bookman, 2005. 


\section{Apêndices}

\section{Apêndice A: Termo de consentimento livre e esclarecido dos/as participantes da pesquisa}

A pesquisa Comunicação Organizacional Integrada Na Universidade de Brasília: um estudo de caso é realizada pelo mestrando Ricardo Borges Oliveira, cel. (61)9267-3926, e-mail: riboli13@gmail.com, do Programa de Pós-Graduação Stricto Sensu em Gestão Pública, da Universidade de Brasília (UnB) e orientando do Prof. Dr. Mário Lúcio de Ávila, e-mail: unbavila@gmail.com. O estudo visa analisar os possíveis impactos nos níveis tático, operacional e estratégico decorrentes da implantação da Superintendência de Comunicação, prevista na proposta de Política de Comunicação Integrada para a Universidade de Brasília.

Para tal fim, o instrumento de pesquisa a ser utilizado será a entrevista semiestruturada com os gestores, servidores e estagiários da Comunicação da UnB. Os relatos serão devidamente gravados e transcritos, a fim de compreender as suas opiniões e percepções a respeito de sua prática profissional, assim como do processo de integração da comunicação social da UnB. A análise do conteúdo será o recurso utilizado a fim de compreender, analisar e interpretar as entrevistas.

Os dados coletados na pesquisa, obtidos nas suas diferentes etapas, além de compor o texto da dissertação de mestrado do pesquisador poderão ser utilizados pelo mesmo na escrita de diferentes artigos e trabalhos científicos que serão encaminhados para publicação em periódicos e para apresentação em eventos científicos. Os/as participantes o fazem por vontade espontânea, e são livres para, a qualquer momento que desejarem e em qualquer fase da pesquisa, recusarem a participar ou retirar seu consentimento de participação, sem qualquer prejuízo aos mesmos e ao pesquisador. Concordando, seu nome e identidade serão mantidos em sigilo.

Caso surjam quaisquer problemas, podem entrar em contato com o pesquisador ou com seu orientador, pelos e-mails e telefones informados além de entrar em contato com a Comissão de Ética em Pesquisa (CEP) da Universidade de Brasília: Prédio da Reitoria, Gabinete do Reitor, $3^{\circ}$ andar, Sala A3 -14/10. Campus Universitário Darcy Ribeiro. Asa Norte. Brasília- DF. CEP 70910-900.

$\mathrm{Eu}$, declaro, que li não somente esse documento, mas também conheci o projeto de pesquisa na íntegra e tive a oportunidade de discuti-lo com o pesquisador. Entendi as informações fornecidas e sinto-me esclarecido/a participar da pesquisa, dando o meu consentimento livre e esclarecido.

Assinatura: Data: 


\section{Apêndice B: Roteiro de entrevista}

APRESENTAÇÃO: apresentação do entrevistador, agradecimento por conceder a entrevista, informação sobre o objeto da pesquisa, local de trabalho e data.

\section{EIXO: CARACTERÍSTICAS PESSOAIS DO ENTREVISTANDO}

Nome (gostaria de usar pseudônimo?), idade, sexo, formação (graduação e pós), tempo de serviço, jornada de trabalho.

\section{EIXO: CARACTERÍSTICAS PROFISSIONAIS DO ENTREVISTANDO:}

\section{GESTOR}

1. Qual o nível de gestão você atua?

2. Há quanto tempo você atua como gestor/a? Por que você decidiu ser gestor/a e deixar de atuar em sala de aula?

3. Fale sobre a sua trajetória profissional.

4. Você já atuou em funções diferentes na gestão? Fale sobre essas diferentes vivências.

5. Foi você quem escolheu trabalhar neste cargo, por quê? Comente um pouco sobre isso.

6. Descreva as funções relativas ao cargo em exercício.

7. Em sua opinião, qual é o principal desafio relativo ao seu cargo em exercício?

\section{SERVIDOR}

1. Qual o seu local de trabalho na UnB?

2. Qual o seu tempo de serviço na UnB?

3. Fale sobre a sua trajetória profissional e suas diferentes vivências.

4. Descreva as funções relativas ao cargo em exercício.

5. Em sua opinião, qual é o principal desafio relativo ao seu cargo em exercício?

\section{ESTÁGIÁRIO}

1. Qual o seu curso de graduação na UnB?

2. Em qual semestre você está?

3. Qual o seu setor de estágio?

4. Descreva as funções exercidas no estágio.

5. Em sua opinião, qual é o principal desafio relativo ao estágio?

\section{EIXO: RELAÇÃO COM A COMUNICAÇÃO DA UnB}

1. Você conhece os setores de comunicação da UnB?

2. Você conhece os profissionais da área de comunicação da UnB?

3. Quais instrumentos de comunicação da UnB você conhece? Quais dele você lê ou assiste?

4. Você já teve algum tipo de envolvimento ou interação com a área de comunicação da UnB? Exemplifique.

5. Como você avalia a comunicação na UnB? 


\section{EIXO: RELAÇÃO COM O PLANEJAMENTO DA COMUNICAÇÃO}

1. Como você conceitua planejamento?

2. Em sua opinião, qual é a importância do planejamento?

3. Qual é a importância do planejamento estratégico da comunicação na UnB?

4. Qual é a importância do planejamento tático da comunicação na UnB?

5. Qual é a importância do planejamento operacional da comunicação na UnB?

6. Como você avalia o planejamento atual da comunicação da UnB?

\section{EIXO: RELAÇÃO COM A COMUNICAÇÃO INTEGRADA}

1. O que você entende por comunicação organizacional integrada?

2. Você considera importante integrar os setores da comunicação da UnB?

3. Quais mudanças você considera que são importantes para que ocorra a integração da comunicação da UnB?

4. Quais são os desafios para a integração da comunicação da UnB?

5. Que tipo de ação contribuiria para a integração dos setores de comunicação da UnB?

6. Você avalia que a integração dos setores de comunicação da UnB possibilitaria uma maior sinergia com os campi e a expansão do setor de comunicação destes?

7. Você conhece experiências de comunicação integrada em outras universidades?

\section{EIXO: RELAÇÃO COM A SUPERINTENDÊNCIA DE COMUNICAÇÃO DA UNIVERSIDADE DE BRASÍLIA}

1. Você avalia que a criação de um órgão que articule as ações de comunicação no âmbito da UnB, como uma superintendência, pode, de fato, instituir uma política de comunicação integrada na universidade?

2. Quais são as vantagens da criação de uma superintendência de comunicação na UnB?

3. Quais as consequências que você identifica com a criação de uma superintendência que agregue os setores de comunicação da UnB?

4. Quais etapas você considera que são importantes seguir para a efetiva implantação da superintendência?

5. Em sua opinião, a criação de uma superintendência pode, de alguma forma, favorecer a um maior protagonismo dos servidores da UnB no planejamento das ações de comunicação da universidade?

6. Você tem conhecimento sobre o grupo de trabalho criado e regulamentado para tratar da política de comunicação integrada da UnB?

7. Você avalia que pode ser afetado de alguma forma com a criação de uma superintendência de comunicação da UnB?

\section{CONSIDERAÇÕES FINAIS:}

1. Para você, falta mais espaço para a participação da comunidade acadêmica no planejamento estratégico da comunicação da UnB?

2. Você percebe a necessidade de mais conhecimento sobre a comunicação da UnB?

3. Gostaria de acrescentar algo relacionado à entrevista?

4. Existe mais alguma outra coisa que gostaria de comentar? 
Apêndice C: Adaptação do questionário aos objetivos da pesquisa

\begin{tabular}{|l|l|l|}
\hline Categorias & Objetivo & Perguntas \\
\hline $\begin{array}{l}\text { Setores de comunicação da } \\
\text { UnB }\end{array}$ & $\begin{array}{l}\text { Identificar os setores da } \\
\text { comunicação social da } \\
\text { UnB. }\end{array}$ & $\begin{array}{l}\text { Você conhece os setores de } \\
\text { comunicação da UnB? }\end{array}$ \\
\hline $\begin{array}{l}\text { Gestão da comunicação da } \\
\text { UnB }\end{array}$ & $\begin{array}{l}\text { Analisar o cenário atual da } \\
\text { âmbito da UnB. }\end{array}$ & $\begin{array}{l}\text { Como você avalia o } \\
\text { planejamento atual da } \\
\text { comunicação da UnB? }\end{array}$ \\
\hline $\begin{array}{l}\text { Comunicação } \\
\text { organizacional integrada }\end{array}$ & $\begin{array}{l}\text { Verificar a teoria e a } \\
\text { prática da comunicação } \\
\text { organizacional na proposta } \\
\text { de gestão de comunicação } \\
\text { integrada. }\end{array}$ & $\begin{array}{l}\text { Quais mudanças você } \\
\text { importantes para que } \\
\text { ocorra a integração da } \\
\text { comunicação da UnB? }\end{array}$ \\
\hline $\begin{array}{l}\text { Comunicação integrada em } \\
\text { outras IES }\end{array}$ & $\begin{array}{l}\text { Comparar experiências de } \\
\text { gestão integrada no âmbito } \\
\text { da comunicação de } \\
\text { instituições de ensino } \\
\text { superior públicas no País. }\end{array}$ & $\begin{array}{l}\text { Você conhece alguma } \\
\text { experiência de } \\
\text { comunicação } \\
\text { organizacional integrada } \\
\text { em outras universidades } \\
\text { públicas (IES)? }\end{array}$ \\
\hline $\begin{array}{l}\text { Superintendência de } \\
\text { Comunicação da UnB }\end{array}$ & $\begin{array}{l}\text { Analisar o modelo } \\
\text { proposto Superintendência } \\
\text { de Comunicação na UnB. }\end{array}$ & $\begin{array}{l}\text { Você avalia que a criação } \\
\text { de um órgão que articule as } \\
\text { ações de comunicação no } \\
\text { âmbito da UnB, como uma } \\
\text { superintendência, pode, de } \\
\text { fato, instituir uma política } \\
\text { de comunicação integrada } \\
\text { na universidade? }\end{array}$ \\
\hline Fona
\end{tabular}

Fonte: elaboração do autor 


\section{Anexos}

Anexo A: Resolução da Vice-Reitoria n. ${ }^{\circ}$ 04/2013

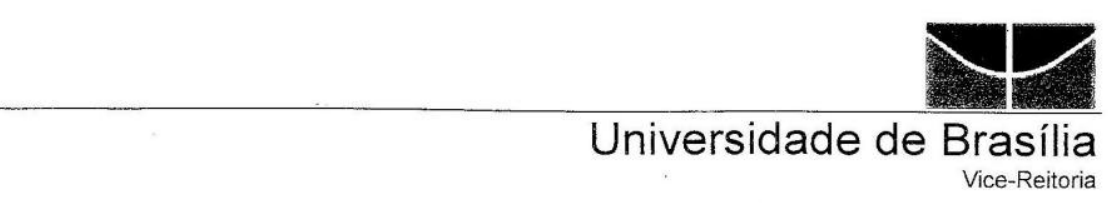

RESOLUÇÃO DA VICE-REITORIA N. O C /2013

Constitui Comissão para formular e apresentar plano de articulação entre as diversas unidades de comunicação da UnB.

atribuições estatutárias,

A VICE-REITORA DA UNIVERSIDADE DE BRASÍLIA, no uso de suas

\section{RESOLVE:}

Constituir Comissão composta pelos servidores Neuza Meller Maia (CPCE); Ana Valéria Machado Mendonça (DSC) e Nelia Rodrigues Del Bianco (FAC), para, sob a presidência do primeiro e no prazo de 60 (sessenta) dias, formular e apresentar plano de articulação entre as diversas unidades de comunicação da Universidade de Brasília.

Brasília, $\rfloor \perp$ de fevereiro de 2013.

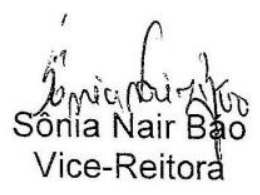

neuzam@gmail.com/nbianco@uol.com.br/valeriamendonça@unb.br

\begin{tabular}{llll}
\hline Universidade de Brasilia & Campus Universitário Darcy Ribeiro & Tel. (61) 3307 2201/3307 2211 & $\begin{array}{l}\text { E-mail: vicereit@unb.br } \\
\text { Vice-Reitoria }\end{array}$ \\
Hoglo-900 Bage: http://www.unb.br
\end{tabular}


Anexo B: Resolução da Vice-Reitoria n..$^{0}$ 11/2013

\section{Universidade de Brasília

RESOLUÇÃO DA VICE-REITORIA N. J 112013

Constitui Comissão para avaliar a
proposta do plano de articulação
apresentada pela comissão composta pela
Resolução da VRT 004/2013.

A VICE-REITORA DA UNIVERSIDADE DE BRASÍLIA, no uso de suas atribuições estatutárias,

\section{RES OLVE:}

Art. $1^{\circ}$ Constituir Comissão para, no prazo de 60 (sessenta) dias, avaliar a proposta de plano de articulação entre as diversas unidades de comunicação da Universidade de Brasília, apresentada pela Comissão nomeada pela Resolução da Vice-Reitoria $n$. 04/2013.

Art. $2^{\circ}$ Esta comissão será constituída pelos seguintes membros:

- Neuza Meller Maia (CPCE) Presidente

- Ana Valéria Machado Mendonça (DSC)

- Nelia Rodrigues Del Bianco (FAC)

- Shirley Gonçalves de Oliveira (SECOM)

- Daniel Souza Peixoto (EDU)

- Rosangela Barz (PROMEMORIA)

- Cynthia Roncaglio (CEDOC)

- Elmira L. Melo Simeão (FCl)

- Carlos Eduardo da Costa Esch (FAC)

- Célia G. Rocha (CIC)

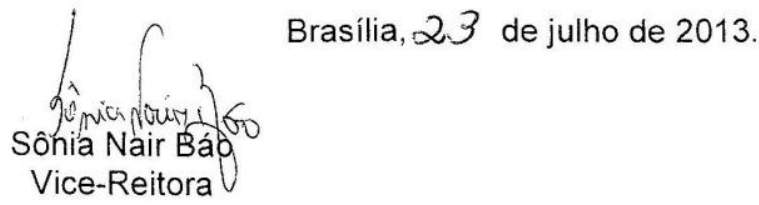

\begin{tabular}{|c|c|c|c|}
\hline $\begin{array}{l}\text { Universidade de Brasilia } \\
\text { Vice-Reitoria }\end{array}$ & $\begin{array}{l}\text { Campus Universitário Darcy Ribeiro } \\
70910-900 \quad \text { Brasilia, DF }\end{array}$ & Tel. (61) $33072201 / 33072211$ & $\begin{array}{l}\text { E-mail: vicereit@unb.br } \\
\text { Home Page: http://www.unb.br }\end{array}$ \\
\hline
\end{tabular}




\section{Anexo C: Memorando sobre o relatório final que estabelece proposta de uma política de comunicação para a UnB}
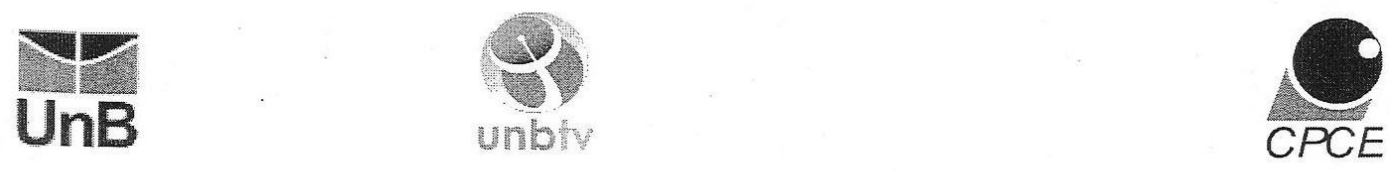

FUNDAÇÃO UNIVERSIDADE DE BRASÍLIA - FUB CENTRO DE PRODUÇÃO CULTURAL E EDUCATIVA-CPCE

Memo: 66/2014/CPCE.

Brasilia, 27 junho de 2014.

Do: CPCE

Para: Vice-Reitora - VRT.

Assunto: Resoluções dạ VTR 11/2013 e 14/2013

Magnifica Senhora Vice-Reitora,

Em resposta ao UnBDoc: 19765 / 2014, encaminho relatório final que estabelece proposta de uma Política de Comunicação Integrada para a Universidade de Brasília. Com o intuito de não prorrogar mais o processo de confecção deste documento, o grupo optou por encaminhar este, contemplando apenas as áreas diretamente envolvidas com a Comunicação da UnB (Secom, TV e Rádio), deixando para uma segunda etapa a possibilidade de junção de outros setores da Universidade como Editora, CIC, FCI etc.

Sugerimos que o documento seja analisado pela PJU para verificar a legalidade da proposta e seguirem com os encaminhamentos possíveis.

Atenciosamente,

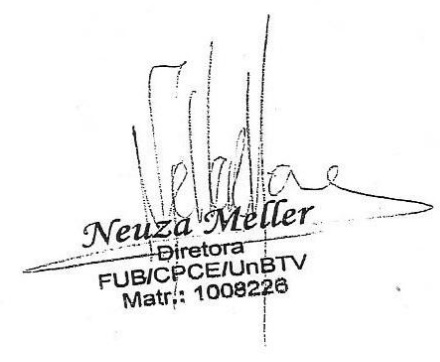

Campus Universitário Darcy Ribeiro ICC NORTE; BL C; MÓDULO 22; SL 576 Distrito Federal - BRASIL Fone (061) 33073343

CGC: 00.038.174/0001-43 E-MAIL: cpce@unb.br HOMEPAGE: www.cpce.unb.br 


\section{Anexo D: Organograma da UnB}

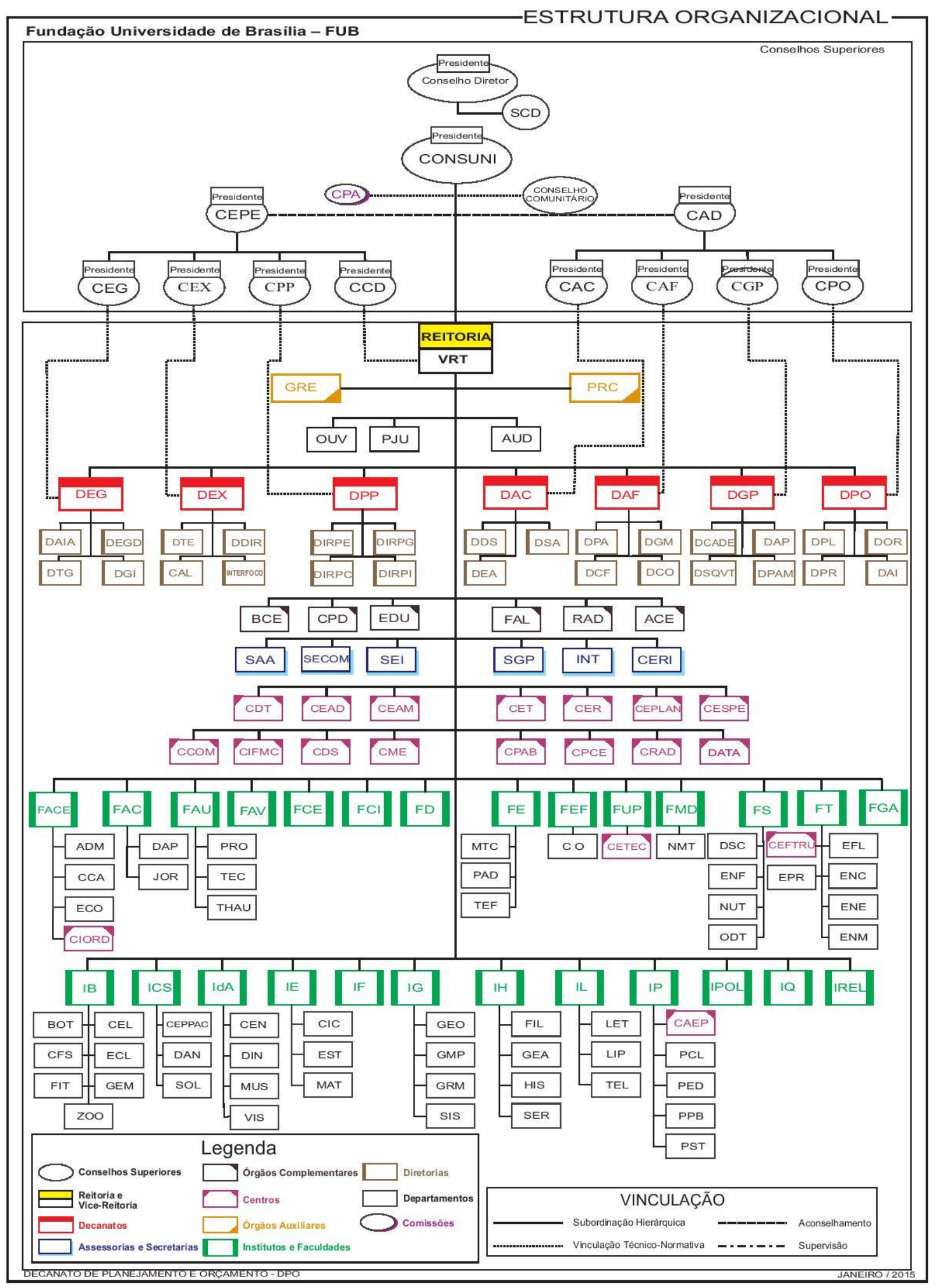




\title{
Anexo E: Institucionalização da UnBTV
}

\section{Universidade de Brasilla}

\author{
ATO DA REITORIA N. $0296 / 2015$
}

Formaliza, no âmbito do Centro de Produção Cultural e Educativa (CPCE), a UnBTV.

BRASÍLIA, O PRESIDENTE DA FUNDAÇÃO E REITOR DA UNIVERSIDADE DE UnBDoc n. 23106/2015,

\section{RESOLVE:}

Art. 10

Formalizar, na estrutura organizacional do CPCE, a UnBTV, que tem como missão divulgar o ensino, a pesquisa e a extensão da Universidade de Brasília, difundir o conhecimento e a cultura e contribuir para a formação de profissionais em audiovisual por meio de suas produções.

Art. 2o A responsabilidade pelas atividades exercidas pela UnBTV é a
Direção do CPCE.

Art. 3으 Este Ato entra em vigor a partir desta data.

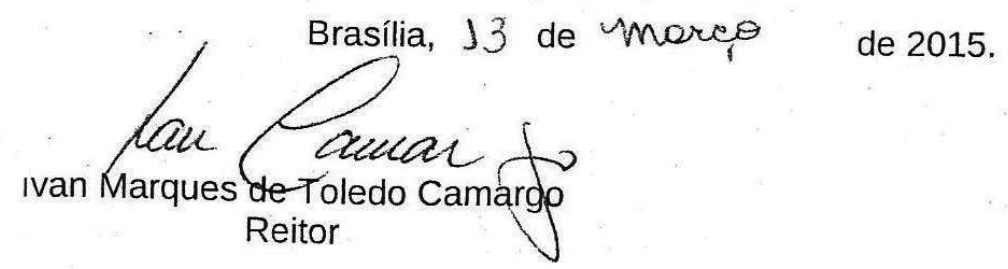




\section{Anexo F: Relato sobre a Rádio UnB}

Texto de autoria do professor da Faculdade de Comunicação (FAC/UnB) e coordenador do processo de implantação da emissora, Carlos Eduardo Esch, sobre a Rádio UnB, apresentado em maio de 2013 à Reitoria.

A criação de uma Rádio UnB consta da estrutura organizacional da Universidade. Conforme prevê o art. 40 do Estatuto, a emissora seria um entre os órgãos complementares, além da TV.

Em 2004 e após intensa atividade da Universidade de Brasília, durante a gestão do prof. Lauro Morhy ao longo de dois ou três anos junto ao Congresso Nacional e ao Ministério das Comunicações, um decreto legislativo concede para a FUBRA o canal 222 E (FM 92.3) de radiodifusão sonora, tipo educativo, em frequência modulada.

A alocação desse canal de radiodifusão ocorreu na FUBRA somente porque existiam, na época, interpretações jurídicas e administrativas controversas - no âmbito governamental - que defendiam que instituições do poder executivo (autarquias e/ou fundações) não poderiam ser contempladas com canais de radiodifusão em cidades onde já houvessem canais públicos alocados para a antiga RADIOBRAS, precursora da atual EBC. Como em Brasília já existiam emissoras como as Rádios Nacional AM e FM entre outras, seria questionável conceder um canal para UnB.

A FUBRA foi escolhida como entidade para receber tal canal por ser, na época, uma fundação controlada pela Reitoria da UnB e que apoiava ações da universidade em diversas áreas de execução de projetos. No entanto, todo o desenvolvimento do projeto Rádio UnB, cobertura de custos, elaboração de processo de gestão, de criação de programação, de contratação de pessoal, de serviços técnicos especializados entre outros, seria de inteira responsabilidade da UnB como a real e fiel desenvolvedora e mantenedora da ideia.

Dentro desse contexto, foi assinado em 2006 um convênio de cooperação com a FUBRA - que durou quase três anos - para que a universidade oferecesse apoio na implantação, gestão e operação da emissora. Por meio desse convênio foram adquiridos todos os equipamentos do parque de transmissão da emissora com recursos da FUB repassados para a FUBRA no valor total aproximado de $\mathrm{R} \$ 880.000,00$. Todos os equipamentos adquiridos pertencem à universidade e estão sob patrimônio e guarda da FUB. Os equipamentos foram instalados na cobertura do Top Mall, em Taguatinga, e estão em condições de funcionamento.

Mesmo com os equipamentos de transmissão, a UnB não havia designado até 2009 um local para funcionamento dos estúdios de produção e transmissão, nem mesmo havia adquirido os equipamentos necessários para essa atividade, o que impedia o funcionamento pleno da emissora. Além disso, o Ministério das Comunicações levou três anos (2005-2008) para autorizar a instalação do sistema irradiante. Sem essa autorização não era possível a realização de vistoria do ministério que permitiria liberar a emissoras para operar em caráter experimental.

Por volta de 2009, alguns fatos iniciam uma trajetória conturbada para a FUBRA e isso ocasiona graves consequências para o andamento do projeto Rádio UnB. Uma primeira situação foi a perda de controle da FUBRA por parte da Reitoria da UnB. Em uma troca de diretoria, a referida fundação "foi tomada" e passou a ser controlada por um grupo não mais relacionado diretamente com a Reitoria da universidade.

Simultaneamente a esta mudança, a FUBRA entra - ao redor de 2009 - em uma séria crise a partir de questionamentos sobre a legalidade de ações e contratos realizados por ela com a UnB e outras instituições públicas. A fundação passa então a ter problemas graves de ordem econômica e jurídica ao longo de dois anos, o que termina levando o Ministério Público do DF, através da Procuradoria de Fundações, a iniciar um processo no sentido de extingui-la, o que foi feito em 2011/2012.

Diante do quadro de incertezas institucionais relacionadas com a crise da FUBRA, foram iniciados estudos da legislação e, principalmente, contatos com diversos segmentos administrativos e jurídicos do Ministério das Comunicações, incluindo dois ministros de Estado da pasta, no sentido de obter informações do que poderia ser feito para evitar a perda do canal de rádio que estava sob responsabilidade da FUBRA, caso esta entidade viesse a ser fechada ou extinta.

Após uma série de reuniões no Ministério das Comunicações, foi indicada a possibilidade de se construir uma situação que poderia solucionar a questão do canal de rádio. Para isso, a direção da FUBRA deveria encaminhar ao ministério um documento cujo conteúdo indicasse que a entidade não teria condições de explorar o canal e o devolveria ao Ministério das Comunicações.

A Reitoria iniciou uma série de contatos com a direção da FUBRA para sensibilizá-la sobre a importância da questão para a universidade e solicitar que eles encaminhassem a carta devolvendo o canal. Inclusive uma minuta de texto foi encaminhada para a fundação no sentido de acelerar o processo de devolução, já que o processo de sua crise havia se aprofundado enormemente. Apesar da insistência no apelo realizado ao presidente da FUBRA na época, professor da universidade, a direção da FUBRA recusou-se a assinar a carta e encaminhála ao Ministério das Comunicações. 
Diante da recusa da FUBRA, configurou-se uma das situações problemáticas no processo da Rádio UnB: o Ministério Público do DF terminou pedindo a extinção da FUBRA e arrolou o canal de radiodifusão como um "suposto patrimônio" da massa falida. Coisa que certamente não o é.

Para evitar que o canal da UnB fosse redirecionado a outra entidade, após avaliação da conjuntura legal, uma das melhores alternativas encontrada foi estabelecer uma negociação com a EBC para que esta entidade solicitasse ao Ministério das Comunicações o referido canal da FUBRA para que ela própria o explorasse aqui em Brasília. Pela atual legislação, a EBC é o ente que gerencia o sistema público de radiodifusão e ao qual pertencem os canais de natureza pública/educativa no Brasil.

Por trás da solicitação do canal da EBC havia, e ainda há, a ideia de que a UnB firmaria um convênio com a EBC para ser a gestora do referido canal de rádio no DF, assim como já acontece com outras 30 entidades de ensino superior espalhadas pelo país. Nessa situação, a EBC permaneceria como "proprietária" do canal, mas repassaria a exploração/gestão do mesmo para a nossa instituição.

No entanto, nenhuma dessas tentativas de resolver os problemas surgidos no desenvolvimento do projeto Rádio UnB obteve êxito. Com a decretação do processo de extinção por parte do Ministério Público, o canal foi incorporado à massa falida da FUBRA, que consta do processo encaminhado para a Justiça Federal em Brasília, o que levou a um impasse existente nesse processo da Rádio UnB até o presente momento.

Foram mais de anos de luta para o enfrentamento dos múltiplos problemas que têm surgido no desenvolvimento do projeto de criação e instalação da Rádio UnB, a universidade investiu significativos recursos públicos, na casa dos milhões de reais, na construção de instalações da emissora (2010-2011), que incluem estúdios, área técnica, redações, área administrativa e, sobretudo, transmissores que já estão, inclusive, instalados aguardando o desfecho deste processo. Foram adquiridos também os equipamentos eletrônicos dos estúdios, proteção elétrica, links, antenas de transmissão, softwares de automação radiofônica, além da estrutura de informática.

No final de 2012, iniciamos um conjunto de reuniões com representantes da direção e da área jurídica da EBC e do Ministério das Comunicações. O objetivo dos encontros foi discutir possíveis caminhos que teríamos para enfrentar: o impasse do "aprisionamento" do canal de rádio no processo judicial de extinção da FUBRA.

Como resultado das discussões, surgiu o argumento dos especialistas jurídicos da EBC e do ministério de que a universidade poderia e deveria realizar ações junto ao juiz federal - já que ainda não há um gerente da massa falida - responsável pelo processo de extinção da FUBRA para que se aventasse, perante o magistrado, a possibilidade de que ele, a partir de um conjunto de argumentos apresentados pela UnB, e com apoio da própria EBC, antecipasse a devolução do canal para o Ministério das Comunicações. A proposta de ação nesse sentido foi encaminhada em abril ao gabinete do Reitor da UnB para providências.

Até o momento, a Rádio UnB não se constituiu como órgão complementar da UnB, conforme prevê estatuto, sequer tem orçamento próprio, e todos os recursos aplicados na construção de estúdios, instalações e compra de equipamentos foram designados pelo gabinete do reitor. Tampouco a Rádio UnB está subordinada a unidade acadêmica. Todas as questões administrativas e financeiras são encaminhadas e negociadas pelo coordenador do processo de implantação da emissora, Carlos Eduardo Esch, com supervisão da direção da Faculdade de Comunicação e do gabinete do Reitor.

Ainda que a questão jurídica seja resolvida e a concessão retorne a UnB, resta um problema grave a ser resolvido. A área onde foram instalados os estúdios, no subsolo do ICC Central, foi parcialmente destruída com as enchentes de 2011. Toda a parede do estúdio principal precisa ser reconstruída, assim revestimento acústico. Os estúdios principal e auxiliares tiveram o carpete destruído. Há a necessidade de uma obra de infraestrutura que evite novos alagamentos no local devido a infiltração no solo. As obras de reconstrução estão orçadas em 500 mil reais.

É importante salientar que a emissora, quando entrar em funcionamento, terá de ser dotada de estrutura própria de pessoal para produção de conteúdo - jornalistas, locutores e produtores - e de técnicos especializados - operadores de áudio, engenheiros, técnico de manutenção, entre outros. Além disso, será necessário dotá-la de orçamento próprio para produção e manutenção. 


\title{
Anexo G: Proposta de Política de Comunicação Integrada para a Universidade de Brasília
}

O texto abaixo é uma proposta elaborada por parte dos membros de comissão (Resolução da Vice-Reitoria n. $^{\circ}$ 04/2013) formada por representantes do CPCE/UnBTV, Secom, Rádio UnB e professores da FAC/UnB.

\author{
Fundação Universidade de Brasília \\ Resolução n. ${ }^{\circ}$ 004/2013 \\ Estabelece a Política de Comunicação Integrada da Universidade de Brasília
}

O CONSELHO UNIVERSITÁRIO DA UNIVERSIDADE DE BRASÍLIA, no uso de suas atribuições legais, CONSIDERANDO a necessidade integrar as unidades de comunicação da UnB com os propósitos de evitar a dispersão de recursos humanos e materiais e colaborar para uniformizar valores e conceitos, permitindo consolidar a imagem da instituição perante seus públicos interno e externo;

CONSIDERANDO a necessidade de articular as ações de comunicação visando a uma atuação orgânica, baseada no estabelecimento de metas, objetivos, direcionamento estratégico, transparência, eficiência, efetividade e agilidade;

CONSIDERANDO a necessidade de adequar-se às diretrizes da Lei n. $^{\circ} 11.652$ de 07.04.2008, que regula os serviços de radiodifusão pública no âmbito administração federal.

RESOLVE:

Art. $1^{\text {o }}$ - Instituir a Política Comunicação Integrada da Universidade de Brasília (UnB).

Art. $2^{\mathbf{0}}$ - Criar órgão complementar com autonomia financeira nos termos do Estatuto da UnB, capítulo V, artigos 40 a 44, denominado de Superintendência de Comunicação responsável pelo planejamento e execução desta política, além de integrar, coordenar e gerir a Diretoria de Mídia Impressa e Digital, Diretoria da Rádio UnB e Diretoria da UnBTV.

CAPÍTULO I - DA POLÍTICA COMUNICAÇÃO INTEGRADA DA UNIVERSIDADE DE BRASÍLIA Art. $\mathbf{3}^{\mathbf{0}}-\mathrm{Na}$ UnB, a comunicação é entendida como estratégica e transversal às ações e atividades acadêmicas, tendo como objetivo atender aos princípios e diretrizes da instituição, em particular o compromisso com a sociedade, a indissociabilidade de ensino, pesquisa e extensão, o livre acesso ao conhecimento e a promoção de valores democráticos e de cidadania.

Art. $4^{\mathbf{0}}$ - As ações de comunicação da Universidade junto aos seus públicos externo e interno devem ser norteadas pelos seguintes princípios:

a) compromisso com a veracidade das informações, o zelo pela imagem da UnB, o apartidarismo, o respeito à diversidade de pensamento e a economicidade;

b) adoção de critérios de noticiabilidade na prática jornalística, privilegiando o interesse público, a disseminação do conhecimento, a transparência das ações e investimentos no setor público;

c) diálogo com os profissionais e veículos de comunicação de forma que seja dada transparência aos atos da administração e da comunidade universitária, assim como a produção do conhecimento científico e tecnológico produzido no âmbito da Universidade;

d) sustentabilidade nas ações e campanhas de comunicação e marketing, devendo ser evitado o desperdício de recursos naturais quando possível e devendo também a inovação nortear a busca por soluções que contribuam para esse fim;

e) adoção de estratégias e ferramentas tecnológicas que garantam processos transparentes, ágeis e objetivos de comunicação, privilegiando o registro de todas as ações e garantindo a memória da comunicação institucional.

Art. $5^{\circ}$ - Os veículos de radiodifusão e meios e suportes de disseminação de produção audiovisual mantidos pela instituição - Rádio e TV - devem pautar-se pelos conceitos e diretrizes desta política e, em especial, pelos princípios da radiodifusão pública instituídos pela Lei n. ${ }^{\circ}$ 11.652/2008 no tocante à promoção do acesso à informação por meio da pluralidade de fontes de produção e distribuição do conteúdo; à produção e constituição de programação com finalidades educativas, artísticas, culturais, científicas e informativas; a promoção da cultura nacional, estímulo à produção regional e à produção independente; ao respeito aos valores éticos e sociais da pessoa e da família; a não discriminação religiosa, político partidária, filosófica, étnica, de gênero ou de opção sexual; e a participação da sociedade civil no controle da aplicação dos princípios do sistema público de radiodifusão, respeitando-se a pluralidade da sociedade brasileira. 


\section{CAPÍTULO II - DA SUPERINTEDENCIA DE COMUNICAÇÃO DA UNIVERSIDADE DE BRASILIA}

Art. $\mathbf{6}^{\mathbf{0}}$ - A Superintendência de Comunicação da UnB, órgão complementar, instituído por este ato, é vinculado à Reitoria da Universidade de Brasília e tem por finalidade:

a) coordenar, supervisionar e gerir as ações das unidades de comunicação com o propósito de dar coerência e unidade à identidade institucional por meio dos diferentes veículos e suportes utilizados pela UnB, além de integrar atividades e equipes profissionais e otimizar esforços e recursos;

b) garantir condições para a efetiva divulgação às ações da UnB, resultantes de atividades acadêmicas de pesquisa e extensão sob os mais variados formatos e linguagens, para públicos diversos, com qualidade técnica e com ética;

c) executar a política de comunicação da UnB estabelecida neste ato por meio da ação de suas unidades e do Conselho Consultivo.

Art. $7^{\mathbf{0}}$ - Na execução de suas finalidades, a Superintendência de Comunicação da UnB deverá:

a) supervisionar e executar a Política de Comunicação, considerando o caráter aberto, público, educativo e cultural dos veículos de comunicação geridos pela Superintendência;

b) apoiar técnica e administrativamente as unidades de comunicação na execução de suas atividades;

c) aprovar a estrutura de cargos e de pessoal, a política de remuneração e de concessão de bolsas de estágio de cada unidade;

d) intermediar a celebração de convênios, acordos, ajustes, contratos e outros instrumentos jurídicos, com pessoas físicas ou jurídicas, de direito público ou privado, nacionais ou estrangeiras, com organismos financeiros públicos ou privados de apoio e fomento, com o objetivo de obter recursos para financiar as atividades das divisões;

e) conceder bolsas de estudo, pesquisa e extensão universitária, em nível de graduação e de pós-graduação, para o desenvolvimento de projetos e atividades vinculadas com as suas finalidades;

f) elaborar plano de atividades e orçamento anual em comum acordo com as unidades de comunicação e submetêlo à aprovação do Conselho Consultivo;

g) garantir a destinação de recursos no orçamento geral da UnB para as ações das unidades do órgão, conforme plano de atividades anual aprovado pelo Conselho Consultivo;

h) zelar para que as unidades de comunicação estejam funcionando em locais apropriados no exercício de suas atividades;

i) fazer gestões junto aos conselhos superiores da UnB quanto às demandas da Superintendência no sentido de obter estrutura e condições de trabalho, levando em conta a integração física;

j) intermediar a produção, a compra e a permuta de programas de áudio e vídeo educativos, científicos, culturais, artísticos e jornalísticos;

k) apropriar-se dos meios de comunicação para agregar valor aos processos educacionais;

1) promover atividades de capacitação contínua da equipe gestora do órgão, assim como das equipes técnicas de suas unidades de comunicação;

m) escolher, em comum acordo com a Reitoria, os dirigentes das unidades de comunicação, considerando a vinculação ao quadro de funcionários da Universidade, currículo profissional, disponibilidade para se dedicar à tarefa de gestor em tempo integral.

n) elaborar projeto de regimento interno a ser submetido à apreciação do Conselho Consultivo;

o) realizar estudos, pesquisas e análises definidos pelo Conselho Consultivo;

p) implementar outras atividades relacionadas com suas finalidades.

q) manter gestões junto à Ouvidoria da UnB de forma a dar respostas às demandas pertinentes;

r) prover as condições necessárias para o funcionamento articulado entre as diretorias desta Superintendência.

Art. $\mathbf{8}^{\mathbf{o}}$ - As receitas da Superintendência de Comunicação serão compostas por:

a) dotação orçamentária da Universidade de Brasília;

b) recursos oriundos de convênios, contratos e acordos com órgãos ou entidades de governo ou instituições privadas com a finalidade de custear projetos de interesse da Superintendência;

c) receitas de contratos de produção e comercialização de bens, produtos e serviços ofertados pela Superintendência;

d) receitas oriundas de apoio cultural;

e) receitas de doações, contribuições, fundos de pesquisa e auxílios oriundos da União, Estados, Distrito Federal ou Municípios, além de instituições públicas ou privadas, nacionais ou estrangeiras para a execução de suas finalidades;

f) recebimento de royalties, licenciamento e direitos autorais de produtos;

g) outras rendas eventuais.

Art. $9^{\circ}$ - A administração da Superintendência de Comunicação da UnB terá a seguinte estrutura organizacional:

a) Superintendente

b) Conselho Consultivo 
c) Conselho Diretor

d) Secretaria Administrativa

e) Assessoria de Projetos

f) Diretoria de Mídia Impressa e Digital

g) Diretoria da UnBTV

h) Diretoria da Rádio UnB

Art. $\mathbf{1 0}^{\circ}$ - Cabe ao Superintendente:

a) administrar as atividades descritas nos Arts. $6^{\circ}$ e $7^{\circ}$ deste ato;

b) manter e preservar o patrimônio da instituição, constituído de acervos impresso, audiovisual e digital produzidos em seu âmbito de atuação, proporcionando o acesso público;

c) convocar e presidir o Conselho Consultivo;

d) zelar pela ordem e pela eficiência dos trabalhos;

e) articular e integrar as unidades de comunicação;

f) exercer atividades de fiscalização no ambiente da Superintendência;

g) cumprir e fazer cumprir o regimento da Superintendência e as disposições estatutárias e regimentais aplicáveis;

h) cumprir e fazer cumprir as instruções e as determinações aprovadas pelo Conselho Consultivo;

i) apresentar ao Reitor relatório anual das atividades da Superintendência;

j) assumir outras responsabilidades previstas no regimento interno do órgão.

Art. $1^{\circ}$ - O Conselho Consultivo tem a missão de supervisionar as atividades da Superintendência de Comunicação da UnB. No exercício de sua missão tem como atribuições:

a) avaliar plano anual de atividades;

b) avaliar relatório anual de prestação de contas;

c) pronunciar-se sobre a linha editorial e as estratégias da Superintendência, bem como sobre seus programas, projetos, produtos e serviços prestados por meio das divisões do órgão;

d) aprovar as prioridades e metas a serem observadas na execução de suas finalidades;

e) aprovar o regimento interno do órgão.

Parágrafo único - Caberá ao Conselho Consultivo estabelecer seu regimento interno de funcionamento, periodicidade de reuniões e forma de convocação.

Art. 12 ${ }^{\circ}$ - São integrantes do Conselho Consultivo:

a) um representante da unidade de ensino diretamente ligadas ao setor - Faculdade de Comunicação;

b) um representante do Gabinete do Reitor;

c) um representante de cada Diretoria da Superintendência - Diretoria de Mídia Impressa e Digital, Diretoria da UnBTV e Diretoria da Radio UnB;

d) e o superintendente da Superintendência de Comunicação que o presidirá.

Art. $\mathbf{1 3}^{\circ}$ - Cabe aos diretores das unidades que fazem parte da Superintendência de Comunicação:

a) executar plano de ações anual definido em comum acordo com a Superintendência, conforme diretrizes da política de comunicação prevista neste ato;

b) produzir, veicular e distribuir produtos de comunicação conforme diretrizes na política de comunicação prevista neste ato;

c) estabelecer meios e técnicas para realizar o controle de qualidade de seus produtos e serviços;

d) gerir recursos humanos, técnicos, financeiros e patrimoniais com eficiência, qualidade, agilidade, correção e ética;

e) otimizar esforços e recursos na execução de suas atividades;

f) elaborar plano de desenvolvimento estratégico em consonância com a política de comunicação e submetê-lo à aprovação da Superintendência;

g) elaborar projetos de produtos, serviços ou ações que possibilitem captação de recursos por meio de convênios e contratos;

h) produzir e disponibilizar manual de redação, de procedimentos, de instruções e de técnicas para realização de produtos institucionais de comunicação;

i) zelar pelos direitos autorais de publicação impressa ou digital, notícia ou produção fotográfica e audiovisual;

j) elaborar relatório anual de prestação de contas e submetê-lo a avaliação da Superintendência por meio do Conselho Consultivo.

Art. $\mathbf{1 4}^{\mathbf{0}}$ - O Conselho Diretor integra a Superintendência de Comunicação, com função consultiva e deliberativa. 
Parágrafo único. O Conselho Diretor é constituído pelo Superintendente, que o preside, e titulares dos previstos no art. $3^{\circ}$ do presente regimento.

Art. $\mathbf{1 5}^{\circ}$ - Ao Conselho Diretor compete:

a) discutir, examinar, assessorar, propor, avaliar e deliberar sobre temas e ações da Superintendência de Comunicação da Universidade de Brasília;

b) analisar, emitir parecer, deliberar, acompanhar e avaliar o plano de administração, bem como os programas anuais de trabalho, incluindo o orçamento operacional e de investimentos da Superintendência de Comunicação;

c) deliberar e formalizar parecer sobre a assinatura de contratos, convênios, alienação de bens e outros atos de importância para o funcionamento da Superintendência de Comunicação;

d) aprovar e contribuir para as políticas de gestão de pessoas, materiais, equipamentos, finanças e patrimônio da Superintendência de Comunicação, resguardadas as disposições vigentes na Universidade de Brasília.

$\S 1^{\circ}$ Presidirá o Colegiado Diretor, sempre que a ele comparecer, o reitor da Universidade de Brasília.

$\S 2^{\circ}$ O Colegiado Diretor reunir-se-á quinzenalmente em sessão ordinária, convocado por seu Presidente.

$\S 3^{\circ}$ As ausências às reuniões ordinárias do Colegiado Diretor devem ser justificadas ao seu Presidente.

Art. 16 $^{\circ}$ - Compete à Assessoria de Projetos:

a) estimular a realização de ações, atividades e projetos, no campo da comunicação, capazes de proverem recursos, serviços e produtos para a Universidade de Brasília;

b) elaborar projetos voltados para o desenvolvimento de ações no campo da comunicação;

c) acompanhar editais e outros meios que ofereçam informações referentes a oportunidades de ações no campo da comunicação;

d) atender demandas por ações no campo da comunicação, desde que considerada a viabilidade de execução da proposta;

e) prestar contas a respeito das ações desenvolvidas.

Art. $\mathbf{1 7}^{\mathbf{0}}$ - O organograma da Superintendência de Comunicação fica assim constituído:

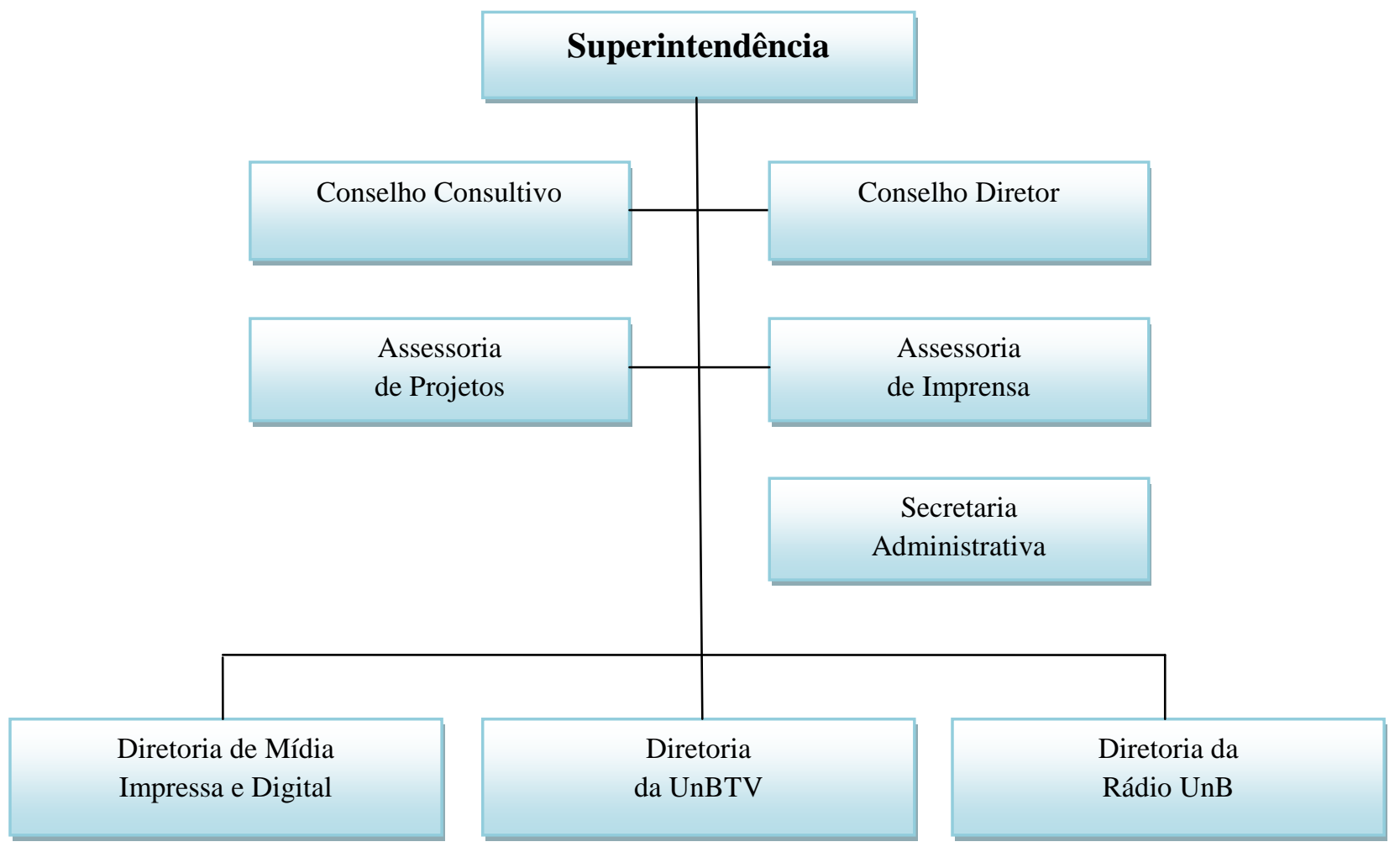




\section{DAS UNIDADES INTEGRANTES DA DIRETORIA DA SUPERINTENDÊNCIA DE COMUNICAÇÃO}

\section{DIRETORIA DE MÍDIA IMPRESSA E DIGITAL}

Art. $\mathbf{1 8}^{\mathbf{0}}$ - A Diretoria de Mídia Impressa e Digital é responsável pela assessoria de imprensa da UnB, gestão e produção de conteúdo impresso e digital da Superintendência de Comunicação e responsável pelo portal da UnB.

Art. $1^{\circ}$ - A Diretoria de Mídia Impressa e Digital é constituída pelos núcleos de:

a) Jornalismo

b) Assessoria de Imprensa

c) Programação Audiovisual e Digital

d) Gestão do Portal

e) Apoio Administrativo

Art. $\mathbf{2 0}^{\circ}$ - Compete à Diretoria de Mídia Impressa e Digital:

a) coletar informações para subsidiar a produção de pautas, notas, matérias, reportagens e compilações jornalísticas nos âmbitos interno e externo à Universidade de Brasília;

b) produzir conteúdo jornalístico que aborde as atividades científicas e culturais da Universidade para os meios digital e impresso, divulgar agenda de eventos, reproduzir artigos de autoria de professores e pesquisadores no portal da UnB ;

c) propor, desenvolver, implantar e manter os veículos de comunicação interna da Universidade de Brasília com o objetivo de promover a divulgação das ações administrativas e acadêmicas, o conhecimento produzido na Universidade, assim como oportunidades de interesse institucional.

d) administrar o Portal da oficial da Universidade de Brasília, bem como seu perfil oficial nas redes sociais.

e) orientar a produção de conteúdo jornalístico para os meios internos e externos;

f) manter contato periódico com representantes da imprensa, especialmente pauteiros, repórteres e editores;

g) acompanhar entrevistas de representantes da Universidade de Brasília, quando demandado;

h) organizar e/ou orientar a realização de entrevistas (coletivas e exclusivas), quando demandadas;

i) orientar a elaboração de textos de apoio e artigos, quando demandados;

j) organizar banco de dados das fontes e de jornalistas;

k) produzir clipping de notícias para a Universidade de Brasília oriundas de diferentes meios;

1) atender a solicitações de produção gráfica de acordo com sua capacidade de processamento técnico, privilegiando as estratégicas, comuns e de maior alcance coletivo;

m) zelar pela utilização da marca institucional e do logotipo da UnB, conforme manual estabelecido pela própria Diretoria de Mídia Impressa e Digital;

n) desenvolver campanhas, materiais institucionais e outros serviços relacionados às áreas de Propaganda e Publicidade.

o) apoiar as atividades de ensino, pesquisa e extensão desenvolvidos no âmbito da UnB.

\section{II - DIRETORIA DA UnBTV}

Art. $2^{\circ}$ - A UnBTV - Canal de Televisão da Universidade de Brasília é responsável pela gestão e produção de conteúdo audiovisual da Superintendência de Comunicação.

Art. $\mathbf{2 2}^{\circ}$ - Compõem a UnBTV as seguintes unidades:
a) Webtv
b) Núcleo de Produção de Vídeo
c) Núcleo de Telejornalismo
d) Acervo

Art. $\mathbf{2 3}^{\circ}$ - Compete à UnBTV:

a) produzir programas de caráter exclusivamente educativo, científico, informativo, cultural, artístico, esportivo, recreativo e de serviços;

b) produzir material audiovisual direcionado ao ensino, pesquisa e extensão;

c) dar suporte às atividades de ensino a distância;

d) transmitir eventos por meio de WebTV;

e) desenvolver e capacitar recursos humanos em seu campo de atuação por meio de estágios e cursos;

f) organizar e gerir os acervos audiovisuais para fins de pesquisa e acesso público;

g) criar, produzir e veicular programas dentro de critérios de qualidade e politica editorial estabelecida pela Superintendência de Comunicação;

h) organizar e publicar a grade de programação; 
i) produzir e manter site da emissora destinado à divulgação da programação, às ações de interação com audiência e transparência de suas ações;

j) gerenciar as equipes, os recursos e os prazos necessários à produção de programas;

k) administrar as atividades estratégicas, táticas e operacionais da UnBTV, preservando a sua imagem, reputação, patrimônio e investimentos, para que os mais altos padrões legais e éticos sejam obedecidos em todas as suas ações;

1) elaborar o caderno de produção contemplando formato, argumento dos programas, características, equipe, relação de créditos, orçamento de produção e outros elementos pertinentes;

m) manter o acervo da emissora, zelando pela organização, indexação de dados, uso e conservação;

n) sugerir à Superintendência mecanismos e meios para ampliar a divulgação da emissora como a instalação de monitores de TV nos campi da UnB.

\section{III - DIRETORIA DA RÁDIO UnB}

Art. $\mathbf{2 4}^{\mathbf{0}}$ - A Rádio UnB é responsável por gerir o canal de rádio concedido à Universidade.

Art. $\mathbf{2 5}^{\circ}$ - A Diretoria de Rádio é constituída por:

I - Direção;

II - Núcleo de Jornalismo;

III - Núcleo de Produção e Programação;

IV - Núcleo de Operação;

$\mathrm{V}$ - Acervo.

Art. $2^{\circ}$ - Compete à Rádio UnB:

a) operar em regime exclusivamente educativo e cultural, a emissora de radiodifusão outorgada à Universidade de Brasília, na conformidade da legislação vigente;

b) produzir e divulgar programas informativos de interesse educativo, científico e cultural;

c) organizar grade de programação;

d) produzir e manter site da emissora destinado à divulgação da programação, às ações de interação com audiência e transparência de suas ações;

e) gerenciar as equipes, os recursos e os prazos necessários à produção de programas;

f) administrar as atividades estratégicas, táticas e operacionais da Rádio UnB, preservando a sua imagem, reputação, patrimônio e investimentos, para que os mais altos padrões legais e éticos sejam obedecidos em todas as suas ações.

g) desenvolver e capacitar recursos humanos em seu campo de atuação por meio de estágios e cursos;

h) apoiar as atividades de ensino, pesquisa e extensão desenvolvidas no âmbito da UnB;

i) difundir programas radiofônicos que promovam os valores e as tradições culturais, especialmente do Distrito Federal;

j) debater temas de interesse público;

k) organizar e preservar o acervo produzido em seu âmbito de atuação, para fins de uso e acesso público.

Art. $2^{\circ}$ - Nos termos da Lei n. ${ }^{\circ} 11.652$ de 07.04.2008 que regula os serviços de radiodifusão pública no âmbito administração federal em seu artigo $3^{\circ}$, a UnBTV e a Rádio UnB se comprometem a:

a) oferecer mecanismos para debate público acerca de temas de relevância nacional e internacional;

b) desenvolver a consciência crítica do cidadão, mediante programação educativa, artística, cultural, informativa, científica e promotora de cidadania;

c) fomentar a construção da cidadania, a consolidação da democracia e a participação na sociedade, garantindo o direito à informação, à livre expressão do pensamento, à criação e à comunicação;

d) cooperar com os processos educacionais e de formação do cidadão;

e) apoiar processos de inclusão social e socialização da produção de conhecimento garantindo espaços para exibição de produções regionais e independentes;

f) buscar excelência em conteúdos e linguagens e desenvolver formatos criativos e inovadores, constituindo-se em centro de inovação e formação de talentos;

g) direcionar sua produção e programação pelas finalidades educativas, artísticas, culturais, informativas, científicas e promotoras da cidadania, sem com isso retirar seu caráter competitivo na busca do interesse do maior número de ouvintes ou telespectadores;

h) promover parcerias e fomentar produção audiovisual nacional, contribuindo para a expansão de sua produção e difusão;

i) estimular a produção e garantir a veiculação, inclusive na rede mundial de computadores, de conteúdos interativos, especialmente aqueles voltados para a universalização da prestação de serviços públicos. 
Art. $\mathbf{2 8}^{\circ}$ - Visando garantir a execução das diretrizes desta política, de seu projeto editorial e das demais disposições previstas na legislação específica (Lei n. ${ }^{\circ} 11.652$ de 07.04.2008), a UnBTV e a Rádio UnB devem constituir um Conselho de Programação para cada emissora com o objetivo de acompanhar a execução das políticas, assim como sua configuração em termos de direção artística e de programação.

Art. $\mathbf{2 9}^{\circ}$ - Cabe ao Conselho de Programação:

a) acompanhar a execução do politica editorial, visando sua efetivação na programação;

b) avaliar detalhadamente a programação quanto a usa qualidade de produção;

c) sugerir ações, enfoques e posturas;

d) elaborar avaliações e notas públicas e/ou a Superintendência caso identifique desvios não respeitados pela Direção da emissora.

Art. 30 ${ }^{\circ}$ - São membros integrantes do Conselho de Programação:

a) diretor da emissora;

b) responsável pela Programação da emissora;

c) um representante dos docentes da UnB, eleito pelos seus pares;

d) um representante dos servidores técnico-administrativos, eleito pelos seus pares;

e) um representante dos alunos de graduação, eleito pelos seus pares.

$\$ \mathbf{1}^{\mathbf{0}}$ - A presidência do conselho deve ser eleita anualmente com a função de coordenação da reunião, montagem da pauta e cobrança de documentos da direção da emissora e da participação dos demais conselheiros.

$\$ \mathbf{2}^{\mathbf{o}}$ - O mandato dos membros do Conselho de Programação será de dois anos, permitida a recondução.

$\$ 3^{\mathbf{o}}$ - O Conselho de Programação criará canais de interlocução com representantes da comunidade, de forma a dispor de avaliação e orientação a respeito do conteúdo veiculado pela Rádio.

\section{DISPOSIÇÕES GERAIS}

Art. $\mathbf{3 1}^{\circ}$ - A implementação desta Política deve ser acompanhada pela vice-reitoria.

Art. $3^{\circ}$ - Esta Política deve ser revista num prazo máximo de 4 (quatro) anos.

Art. $3^{\circ}$ - Caberá a vice-reitoria coordenar a implantação do novo órgão com a interveniência dos atuais dirigentes da SECOM, CPCE e Rádio UnB.

Art. $\mathbf{3 4}^{\mathbf{0}}$ - Fica estabelecido o prazo de seis meses para o início do funcionamento da Superintendência de Comunicação.

Art. $3^{\circ}$ - Esta resolução entra em vigor na data de sua publicação. 